CLAUDIO LUIS CRUZ DE OLIVEIRA

CRIAÇÃO DE VALOR ESTRATÉGICO ATRAVÉS DE DIGITAL ANALYTICS 
CLAUDIO LUIS CRUZ DE OLIVEIRA

\section{CRIAÇÃO DE VALOR ESTRATÉGICO A PARTIR DE DIGITAL ANALYTICS}

Tese apresentada à Escola Politécnica da Universidade de São Paulo para obtenção do título de doutor em Engenharia 
CLAUDIO LUIS CRUZ DE OLIVEIRA

\section{CRIAÇÃO DE VALOR ESTRATÉGICO A PARTIR DE DIGITAL ANALYTICS}

Tese apresentada à Escola Politécnica da Universidade de São Paulo para obtenção do título de doutor em Engenharia

Área de concentração:

Engenharia de Produção

Orientador:

Prof. Dr. Fernando José Barbin Laurindo

São Paulo

2013 
Este exemplar foi revisado e alterado em relação à versão original, sob responsabilidade única do autor e com a anuência de seu orientador.

São Paulo, de fevereiro de 2013.

Assinatura do autor

Assinatura do orientador

FICHA CATALOGRÁFICA

Oliveira, Claudio Luis Cruz de

Criação de valor estratégico através de digital analytics /

C.L.C. de Oliveira. -- ed.rev. -- São Paulo, 2013. $186 \mathrm{p}$.

Tese (Doutorado) - Escola Politécnica da Universidade de São Paulo. Departamento de Engenharia de Produção.

1. Estratégia organizacional 2. Tecnologia da informação 3. Internet I. Universidade de São Paulo. Escola Politécnica. Departamento de Engenharia de Produção II. t. 
DEDICATÓRIA

Ao meu querido avô e padrinho

José Estanislau Kostka de Oliveira (In Memoriam) 


\section{AGRADECIMENTOS}

Ao meu orientador, Fernando José Barbin Laurindo, pela parceria acadêmica e amizade que se estende desde o período do mestrado.

Aos colegas do Grupo de Tecnologia de Informação da Poli-Produção, especialmente à Kumiko Kissimoto, pelas dicas sobre a metodologia e formatação.

Aos amigos que possuem contatos nas empresas analisadas e que abriram portas para elaboração dos estudos de caso.

Ao mestre Joe Campos e equipe, que através do Tae Kwon Do, inseriram uma prática saudável numa rotina atribulada.

Aos meus pais, João Carlos e Jeanette, por terem sido exigentes com a educação e prepararem seus filhos para a vida.

À minha família mais próxima, à Kátia pelo suporte de sempre, à Maria Clara, pelas intervenções bem humoradas e ao Davi, pingo de luz em nossas vidas. 


\section{RESUMO}

A Internet mudou a competição entre as empresas, alterou produtos, cadeias de valor e até mesmo os mercados. Sua democratização aumentou o poder dos consumidores; esta mudança pode ser uma ameaça para as corporações. No entanto, o conhecimento emergente derivado de Digital Analtics gerou uma série de benefícios como a personalização de serviços, o impulso à inovação e a promoção de um diálogo com o consumidor em tempo real.

O conceito de Digital Analytics inclui o monitoramento, a coleta, a análise e a elaboração de relatórios de dados digitais com a finalidade de entendimento e otimização da performance dos negócios. Esse estudo objetiva entender como as empresas brasileiras implementam Digital Analytics para atingir seus objetivos de negócios e, por consequência, suportar uma vantagem competitiva. Uma survey exploratória e múltiplos estudos de caso compõem a pesquisa de campo dessa tese.

Keywords: Digital Analytics. Web Analytics. Estratégia. Internet. E-business. 


\begin{abstract}
Internet has changed the competition, shifting products, supply-chains and even markets. Its democratization gives more weight to the consumers; this change could be considered a threat to corporations. Although, the emergent knowledge derived from Digital Analytics brings a lot of benefits: delivering personalized services, fostering innovation and promoting the dialogue with the consumer in a real time basis.

The concept of Digital Analytics includes the measurement, collection, analysis and reporting of digital data for the purposes of understanding and optimizing business performance. This paper aims to understand why and how the companies implement Digital Analytics in order to achieve business goals and thus support the competitive advantage. An exploratory survey and multiple case studies compound the methodological approach of this paper.
\end{abstract}

Keywords: Digital Analytics. Web Analytics. Strategy. Internet. E-business. 


\section{LISTA DE FIGURAS}

Figura 2.1: Distribuição dos internautas nos países com maior audiência no mundo (adaptado de INTERNET WORLD STATS, 2011) 29

Figura 2.2: Participação dos internautas sobre total da população (adaptado de INTERNET WORLD STATS, 2011)

Figura 2.3: Evolução dos internautas no Brasil (Dados extraídos de IAB BRASIL, 2011) 30

Figura 2.4: Cobertura dos internautas brasileiros por categoria (COMSCORE, 2011) .33

Figura 2.5: Crescimento do Varejo Online (E-CONSULTING, 2011) 34

Figura 2.6: Comparativo do faturamento do e-commerce em diferentes países (Consolidado a partir de ComScore, 2009; IDC apud Hao, 2009; E-consulting, 2009; Research and Markets, 2009)... 36

Figura 2.7: Comparativo do crescimento do e-commerce de 2009 vs 2008 em diferentes países (Consolidado a partir de ComScore, 2009; IDC apud Tao, 2009; E-consulting, 2009; Research and Markets, 2009) .36

Figura 3.1: Cadeia de valor (Porter \& Millar, 1985) .38

Figura 3.2: Sistema de valor (Porter \& Millar, 1985) 38

Figura 3.3: Modelo do alinhamento estratégico (adaptado de Henderson \& Venkatraman, 1993)

Figura 3.4: Perspectivas do alinhamento estratégico (adaptado de Henderson \& Venkatraman, 1993) 42

Figura 3.5: Integração do sistema de valor gerada pela Internet. .43

Figura 3.6 - O espaço virtual, segundo o modelo ICDT (adaptado de Anghern, 1997)

Figura 3.7: Evolução da telecomunicação e sistemas de gestão computacionais (adaptado de Chandrashekar \& Schary, 1999). 46

Figura 3.8: Evolução da telecomunicação e sistemas de gestão computacionais (adaptado de Chandrashekar \& Schary, 1999) 46

Figura 3.9: Cadeia de valor versus rede de valor (adaptado de Bovet \& Martha 2001) 
Figura 3.10: Fontes de criação de valor na Internet (adaptado de Amit \& Zott, 2001)

Figura 3.11: Modelo Fiat Mio apresentado no salão do automóvel de 2010 (YOUTUBE, 2011)

Figura 3.12: Arquitetura de criação (ANDERSON, 2006; SHAMMA et al., 2007)

Figura 3.13: Mudança na demanda da Netflix entre 2000 e 2005 (Anderson, 2009) .55

Figura 4.1: Camadas da hierarquia de dados de DA (CUTRONI, 2010) 60

Figura 4.2: Painel de controle do Google Analytics 62

Figura 4.3: Audiência dos sites sobre livros (GOOGLE ADPLANNER, 2011) ..68 Figura 4.4: Tela do Google ApPlanner (2011) com perfil da audiência dos sites sobre livros. 69

Figura 4.5: Comparação das marcas de livros mais buscadas no Google (GOOGLE TRENDS, 2012) 70

Figura 4.6: Resultados de busca no Google ..............................................

Figura 4.7: Comentários sobre a marca Livraria Cultura no Twitter ...................73 Figura 4.8: Framework de medição de performance digital (MAYAR \& RAMSEY, 2011) .74

Figura 4.9: Exemplo ilustrativo dos tributos da marca de determinado produto (Tamanho das fontes representa frequência dos comentários associados) ......76 Figura 4.10: Funil de conversão do consumidor (CUTLER \& STERNE, 2000).77 Figura 4.11: Um framework organizacional para marketing em múltiplos canais e ambiente multimídia de varejo (SHANKAR \& YADAV, 2010) .......................78

Figura 4.12: Fluxo sistêmico de marketing (YANAZE, 2011) ............................79 Figura 4.13: MCP de faturamento dos 4 grandes clubes de São Paulo (PAVAN et al., 2012) Erro! Indicador não definido. Figura 4.14: Relação entre as perpectivas do BSC (Adaptado de KAPLAN \& NORTON, 1997) .81

Figura 4.15: Quality function deployment (QFD) (SELNER, 1999) ...................82

Figura 4.16: Sete ferramentas da qualidade (DAVIS et al., 2001) ....................83

Figura 15.1: Condução do estudo de caso (MIGUEL, 2007) ...........................89

Figura 15.2: Constructos e variáveis da pesquisa .89 
Figura 16.1: Distribuição das ferramentas de DA entre as maiores empresas de Exame (WA, 2010) 107

Figura 16.2: Fluxo de uma ferramenta de análise da audiência do site (CUTRONI, 2010) 108

Figura 16.3: Temas mais frequentes no fórum Web Analytics Brasil. 112

Figura 17.1: Impacto das forças competitivas para o mercado de software (Elaborado pelo autor, baseado em Porter, 1979) 114

Figura 17.2: Impacto das forças competitivas para o mercado de software (Elaborado pelo autor, baseado em Porter, 1979) 123

Figura 17.3: Impacto das forças competitivas para o mercado de vestuário (Elaborado pelo autor, baseado em Porter, 1979) 131

Figura 17.4: Engajamento à marca (mil usuários) 133

Figura 17.5: Mapa mental sobre percepção da marca 134

Figura 17.6: Hábitos de navegação no site por país 135

Figura 17.7: Impacto das forças competitivas para o mercado de bebidas não alcoólicas (Elaborado pelo autor, baseado em Porter, 1979) 139

Figura 17.8: Impacto das forças competitivas para o mercado de livros didáticos (Elaborado pelo autor, baseado em Porter, 1979) 146

Figura 17.9: Impacto das forças competitivas para o mercado de e-commerce de artigos esportivos (Elaborado pelo autor, baseado em Porter, 1979) 152

Figura 17.10: Impacto das forças competitivas para o mercado de e-commerce de artigos esportivos (Elaborado pelo autor, baseado em Porter, 1979) 159

Figura 17.11: Processo de comunicação e financiamento da Banda Mais Bonita da Cidade. 161

Figura 17.12: Sistema de valor tradicional para indústria fonográfica 163

Figura 17.13: Rede de Valor da Banda Mais Bonita da Cidade 163 


\section{LISTA DE TABELAS}

Tabela 3.1: As quatro eras da computação organizacional (Zwass, 1998)

Tabela 3.2: Exemplos de criação de valor a partir do modelo de negócios (adaptado de Amit \& Zott, 2001) .52

Tabela 4.1: Termos relacionados à DA (WAA, 2008, 2010) .65

Tabela 4.2: KPIs para Digital Analytics (PETERSON, 2006) .66

Tabela 4.3: Quadro comparativo gestão do conhecimento, CRM e CKM (adaptado de Gibbert et al., 2002) .85

Tabela 15.1: Relações entre constructos, variáveis e premissas 94

Tabela 15.3: Casos da pesquisa.

Tabela 15.4: Questões do roteiro semi-estruturado relacionadas ao constructo de Capacidade Analítica

Tabela 15.5: Questões do roteiro relacionadas ao constructo de contribuições da internet para a estratégia 102

Tabela 15.6: Questões do roteiro semi-estruturado relacionadas ao constructo gestão de negócios 103

Tabela 16.1: Uso da internet pelas empresas pesquisadas (as cores mais escuras indicam maior frequencia de respostas) 109

Tabela 16.2: Uso de práticas de DA pelas empresas pesquisadas (as cores mais escuras indicam maior frequencia de respostas) 110

Tabela 17.1: Estudo do Mercado de Comércio Exterior (MDIC, 2008) 117

Tabela 17.2: Aderência das práticas da empresa de software às variáveis do framework de DA 122

Tabela 17.3: Aderência das práticas da montadora às variáveis do framework de DA

Tabela 17.4: Aderência das práticas da empresa de vestuário às variáveis do framework de DA 138

Tabela 17.5: Aderência das práticas da empresa de bebida às variáveis do framework de DA 145

Tabela 17.6: Aderência das práticas da editora às variáveis do framework de DA 
Tabela 17.7: Aderência das práticas da loja de e-commerce às variáveis do framework de DA ...................................................................... 158

Tabela 17.8: Aderência das práticas do grupo musical às variáveis do

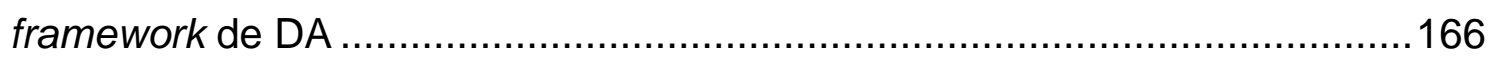

Tabela 18.1: Framework de DA ......................................................... 168

Tabela 18.2: Aderência das variáveis de DA aos estudos de caso .................170

Tabela 18.3: Confirmação das proposições .........................................172 
LISTA DE ABREVIATURAS E SIGLAS

$\begin{array}{ll}\text { B2B } & \text { Business to Business } \\ \text { B2C } & \text { Business to Consumer } \\ \text { B2G } & \text { Business to Government } \\ \text { C2B } & \text { Consumer to Business } \\ \text { C2C } & \text { Consumer to Consumer } \\ \text { C2G } & \text { Consumer to Government } \\ \text { CKM } & \text { Customer Knowledge Management } \\ \text { CRM } & \text { Customer Relationship Management } \\ \text { DA } & \text { Digital Analytcs } \\ \text { G2B } & \text { Government to Business } \\ \text { G2C } & \text { Government to Consumer } \\ \text { G2G } & \text { Government to Government } \\ \text { ICDT } & \text { Information, Communication, Distribution and Transactional } \\ \text { SAAS } & \text { Software as a Service } \\ \text { SEO } & \text { Search Engine Optimization } \\ \text { TI } & \text { Tecnologia da Informação } \\ \text { VCS } & \text { Virtual Communication Space } \\ \text { VDS } & \text { Virtual Distribution Space } \\ \text { VIS } & \text { Virtual Information Space } \\ \text { VTS } & \text { Virtual Transaction Space } \\ \text { WA } & \text { Web Analytics }\end{array}$




\section{SUMÁRIO}

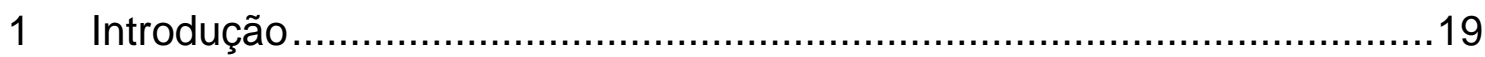

1.1 Digital Analytics (DA) e seu potencial estratégico.................................19

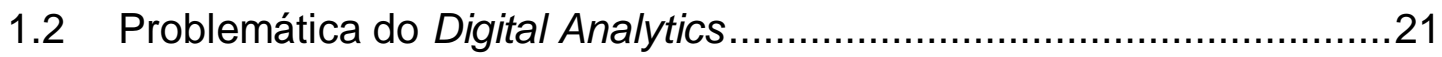

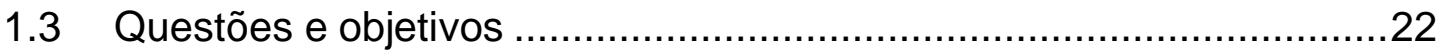

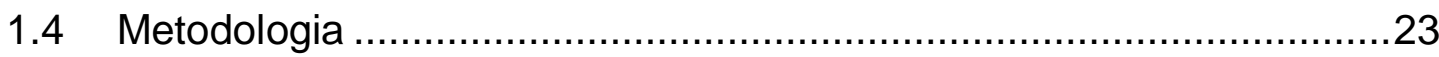

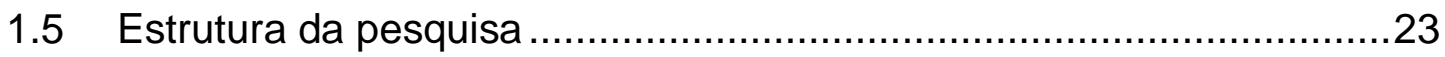

2 Evolução da Internet e os impactos nos negócios e na sociedade.............25

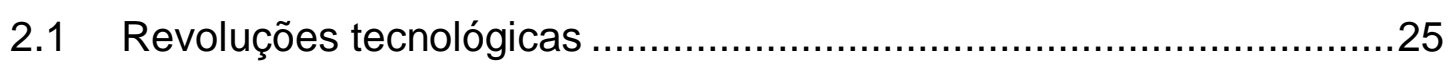

2.2 Evolução da Internet e relevância para sociedade .............................26

2.2.1 Histórico da Internet ..............................................................26

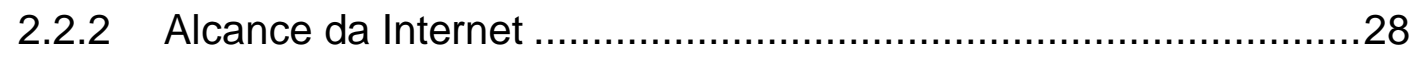

2.2.3 Riqueza das informações ............................................................

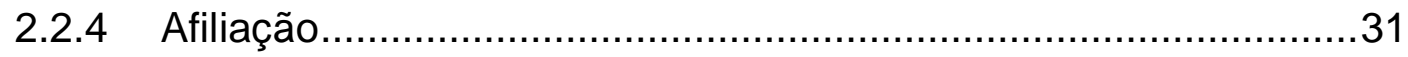

2.3 Impacto da Internet nos negócios ................................................32

2.3.1 O e-business na Internet brasileira..................................................32

2.3.2 Evolução do e-commerce brasileiro e comparativo com outros países 33

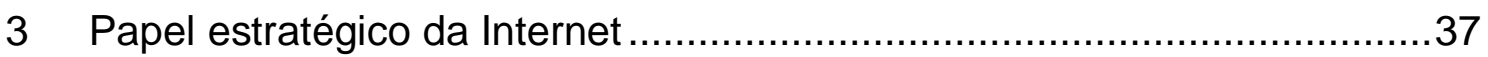

3.1 Evolução do papel da TI nas empresas ............................................37

3.2 Alinhamento entre $\mathrm{Tl}$ e estratégia corporativa ..................................38

3.3 Contribuições da Internet para a estratégia corporativa ......................42

3.3.1 A Internet como integradora do sistema de valor ...........................43

3.3.2 As implicações da virtualidade nos negócios ...............................43

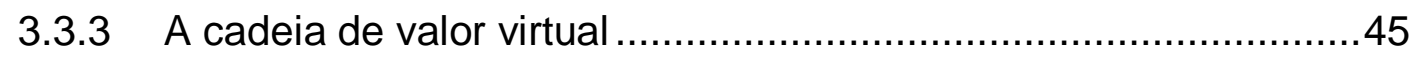

3.3.4 As redes de valor ................................................................ 
3.3.5 Modelos de criação de valor para o e-business .48

3.3.6 A co-criação de valor 51

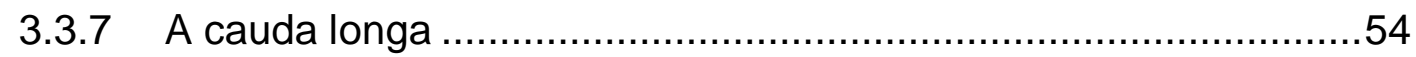

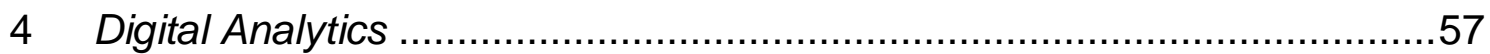

4.1 Conceituação de Digital Analytics ..................................................57

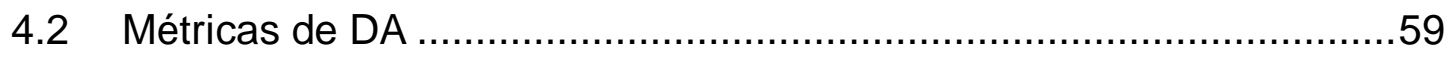

4.2.1 Métricas para presença receptiva .............................................59

4.2.2 Métricas para presença ativa ...................................................62

4.2.3 Métricas para mídias sociais ........................................................63

4.2.4 KPls e consolidação das métricas...............................................63

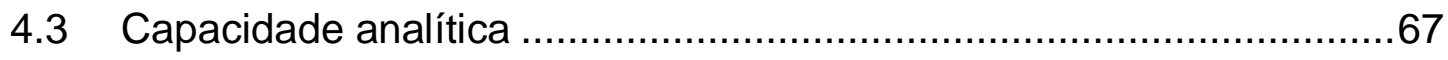

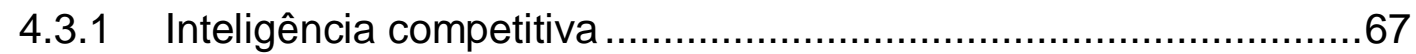

4.3.2 Otimização da presença ativa ..................................................

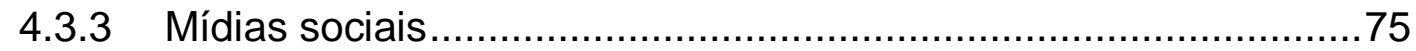

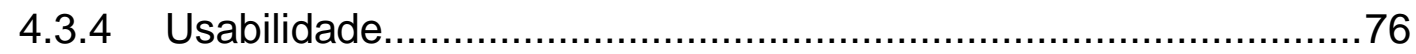

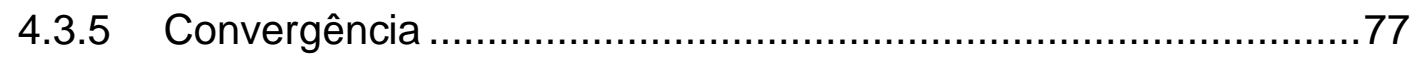

4.4 Elementos de gestão de negócios relacionados à DA ........................78

4.4.1 Planejamento estratégico ........................................................78

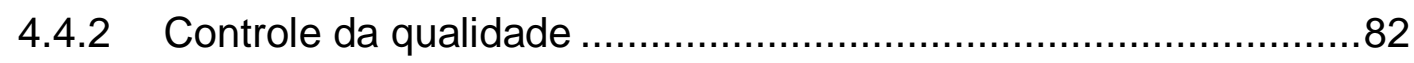

4.4.3 Customer Knowledge Management ….......................................83

4.4.4 Retorno de investimentos em comunicação.................................85

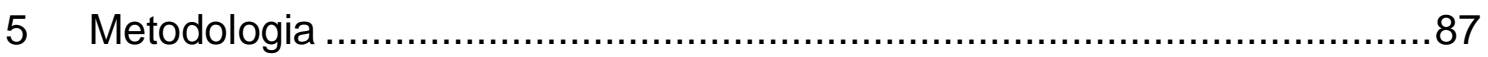

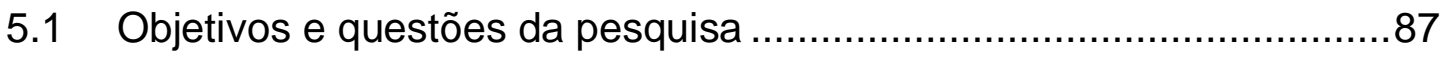

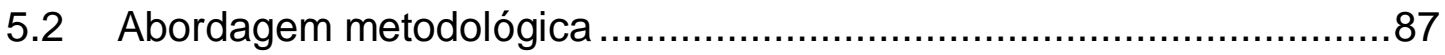

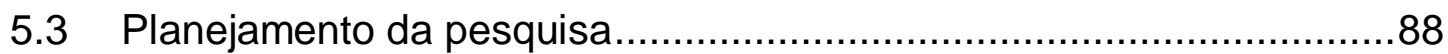

5.4 Definição da estrutura conceitual-teórica..............................................

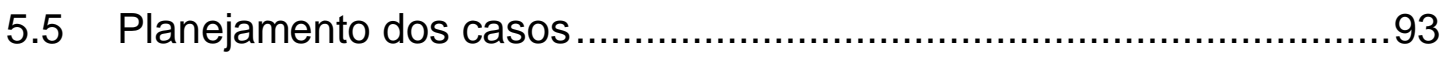




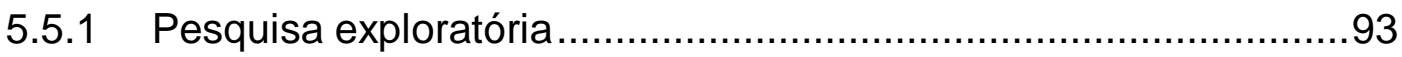

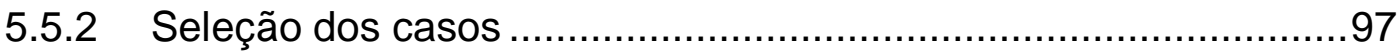

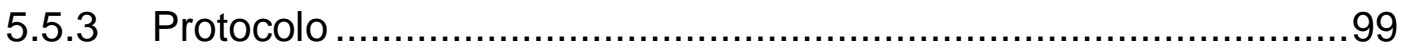

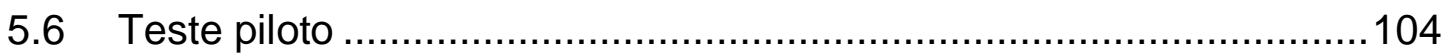

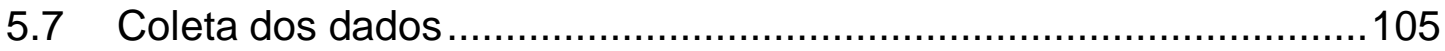

5.8 Análise dos casos e contribuição à teoria........................................105

5.9 Limitações da pesquisa .............................................................106

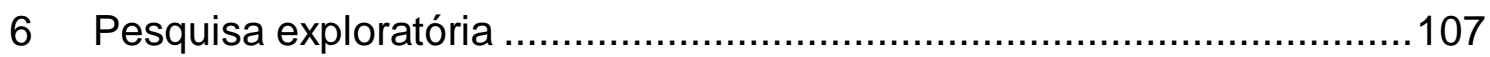

6.1 Aplicação de DA pelas empresas brasileiras ...................................107

6.2 Temas mais frequentes entre profissionais de DA............................111

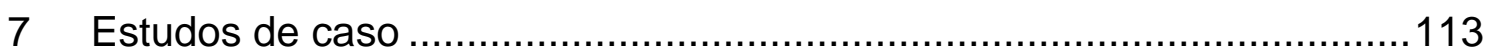

7.1 Estudo de caso A: Empresa de software ......................................113

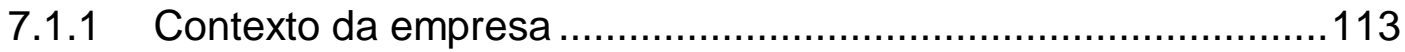

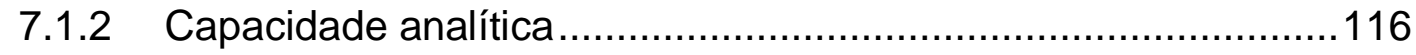

7.1.3 Contribuições da Internet para estratégia .................................118

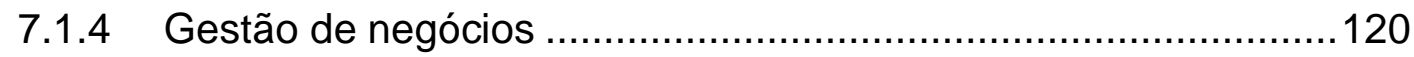

7.1.5 Síntese do estudo de caso .....................................................121

7.2 Estudo de caso B: Montadora......................................................121

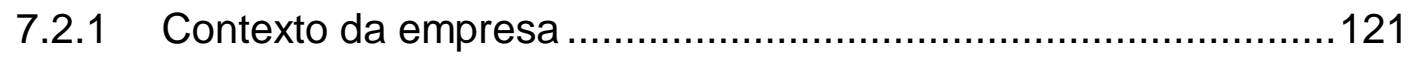

7.2.2 Competência analítica.........................................................125

7.2.3 Contribuições da Internet para estratégia ................................126

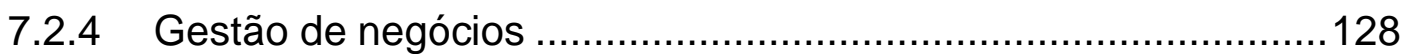

7.2.5 Síntese do estudo de caso ...................................................129

7.3 Estudo de caso C: Empresa do ramo de vestuário.............................130

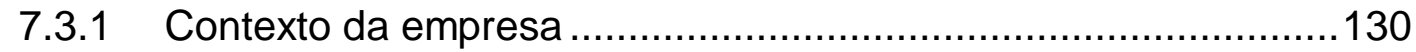

7.3.2 Competência analítica..........................................................132

7.3.3 Contribuições da Internet para estratégia ................................135 


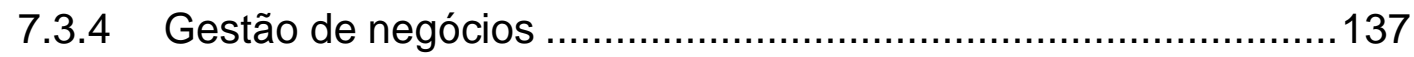

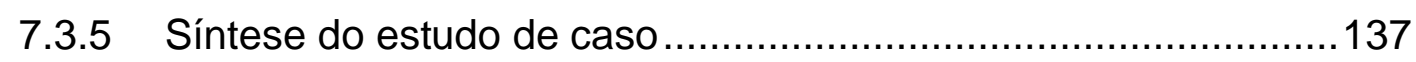

7.4 Estudo de caso D: Fabricante de bebidas .....................................138

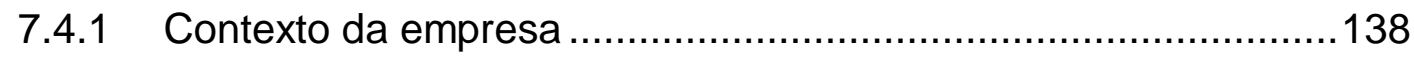

7.4.2 Competência analítica..........................................................140

7.4.3 Contribuições da Internet para estratégia .................................142

7.4.4 Gestão de negócios ...........................................................143

7.4.5 Síntese do estudo de caso ...................................................144

7.5 Estudo de caso E: Editora de livros didáticos ..................................144

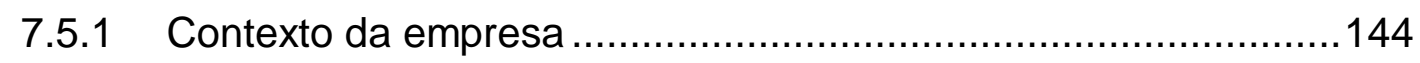

7.5.2 Competência analítica.........................................................147

7.5.3 Contribuições da Internet para estratégia ..................................148

7.5.4 Gestão de negócios .............................................................149

7.5.5 Síntese do estudo de caso ...................................................150

7.6 Estudo de caso F: E-commerce de artigos esportivos .....................150

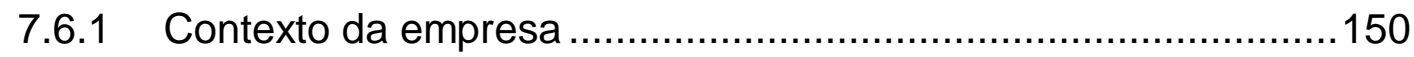

7.6.2 Competência analítica.............................................................153

7.6.3 Contribuições da Internet para estratégia ..................................154

7.6.4 Gestão de negócios ............................................................156

7.6.5 Síntese do estudo de caso ....................................................157

7.7 Estudo de caso G: Grupo Musical "A Banda Mais Bonita da Cidade"159

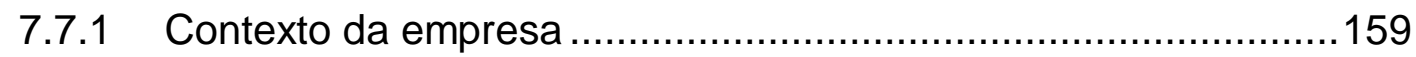

7.7.2 Competência analítica...........................................................160

7.7.3 Contribuições da Internet para estratégia .................................162

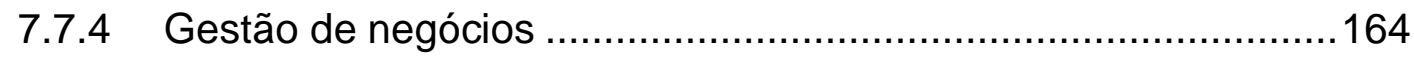

7.7.5 Síntese do estudo de caso ....................................................165

8 Discussão dos resultados da pesquisa..............................................167 


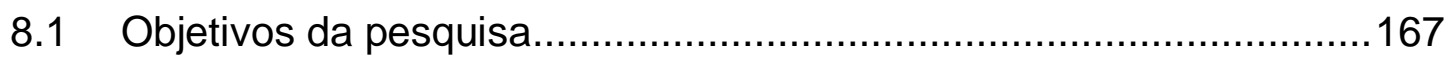

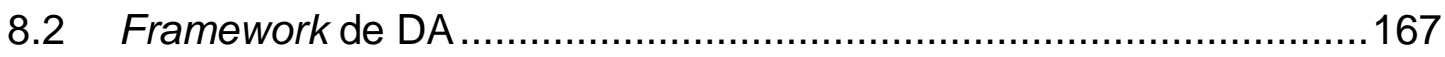

8.3 Aplicação do framework de DA nas empresas brasileiras .................169

8.4 Alinhamento estratégico de DA e sua eficácia para os negócios ......171

8.5 Identificação dos elementos de sucesso na implantação de DA .......172

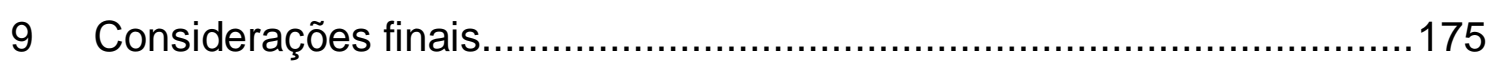

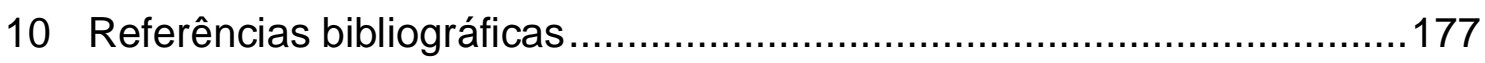




\section{Introdução}

\subsection{Digital Analytics (DA) e seu potencial estratégico}

Digital Analytics (DA) é a medição, coleta, análise e elaboração de relatórios de dados digitais para os propósitos de entendimento e otimização da performance em negócios (CUTRONI, 2012). A indústria de DA nasceu em 1993 com a fundação da empresa WebTrends em Oregon, nos Estados Unidos. Nos três anos seguintes, quatro novas desenvolvedoras de software para coleta de dados sobre as interações do consumidor com sites surgiram (WAA, 2008). Rapidamente esse tipo de tecnologia se disseminou entre as empresas, principalmente, após o advento de ferramentas gratuitas como o Google Analytics (CUTRONI, 2010). Em 2010, no Brasil, pelo menos 74\% das empresas brasileiras listadas entre as 500 maiores da revista EXAME possuíam alguma solução de DA implantada (WA CONSULTING, 2010).

Inicialmente, o termo Web Analytics era utilizado para agrupar esse tipo de análise, porém em 2012, a Web Analytics Association mudou seu nome para Digital Analytics Association oficializando a nova terminologia que será usada ao longo desse estudo (DIGITAL ANALYTICS ASSOCIATION, 2012).

Kaushik (2009) defende um conceito ainda mais amplo de DA, que deve envolver não só os dados quantitativos, mas também deve agregar dados qualitativos como a satisfação do consumidor com a experiência no site e com os produtos da empresa. Nesse conceito ampliado, vislumbra-se a possibilidade das informações sobre DA fornecerem subsídios para um processo de melhoria contínua do relacionamento da empresa com seu consumidor.

O presente estudo pretende explorar o conceito ampliado de DA e avaliar como este conceito pode contribuir para a eficácia organizacional, ou seja, como pode impactar nos objetivos do negócio das empresas brasileiras (LAURINDO, 2008). 
Diante dessa perspectiva, convém observar alguns indícios de que esse tema possa contribuir para as estratégias corporativas e, por isso, merece uma análise mais detalhada.

Considerando as dimensões propostas por Evans \& Wurster (1999) para o ebusiness: alcance, riqueza e afiliação; verifica-se que o potencial de criação de valor da Internet para os negócios no Brasil é cada vez maior. Consequentemente, aumenta-se também o valor das informações de DA que podem tornar cada vez mais estreito o contato com o consumidor na Internet.

Em 2010, o alcance da Internet foi 2,1 bilhões de pessoas mundialmente (INTERNET WORLD STATS, 2011), sendo que no Brasil há 74 milhões de pessoas com acesso à Internet e 20 milhões são e-consumidores (IAB BRASIL, 2011). O acesso através de dispositivos móveis amplia o campo de possibilidades dessas aplicações, no Brasil $41 \%$ dos proprietários de celular navegam na Internet com seus telefones (CAVALLINI \& REIS, 2011).

A riqueza das informações (EVANS \& WURSTER, 1999) pode ser verificada através da profundidade e detalhamento do conteúdo publicado na web que evolui com a penetração da banda larga. Conteúdos multimídia são cada vez mais comuns, permitindo uma comunicação completa com os usuários. O Youtube, site que compartilha vídeos publicados pelos usuários, é o terceiro site mais visitado do mundo e concentra um conteúdo em vídeos maior do que o produzido pelas 3 principais redes de TV americanas (MOL - MARKETING ONLINE, 2011).

Já a afiliação dos internautas (EVANS \& WURSTER, 1999) é expandida nas redes sociais, fóruns e blogs, que são espaços abertos para que o usuário comente suas experiências com produtos e serviços. Dessa forma, o consumidor pode demonstrar seu apreço ou insatisfação com as práticas das empresas, influenciando outros consumidores. No Brasil, mais de $99 \%$ dos internautas acessam redes sociais segundo estudo da empresa de pesquisas ComScore (TAGIAROLI, 2011).

O DA pode ser estratégico ao monitorar as interações desse imenso público com as diversas instâncias da empresa distribuídas na Internet, considerando 
que o próprio usuário pode produzir conteúdos sobre a empresa nas mídias sociais. Esse entendimento apoia os processos em que a empresa se apropria das competências dos consumidores a fim de criar novos produtos e serviços (PRAHALAD \& RAMASWAMY, 2000, 2004; TAPSCOTT \& WILLIAMS, 2007).

As aplicações de Internet também mudam o paradigma da competição, pois aumentam a diversidade de opções para o consumidor final. As novas tecnologias viabilizam financeiramente a produção de pequenos volumes de produção e a Internet disponibiliza esses produtos para um mercado global de maneira eficiente e a baixo custo, transformando a economia de escala em economia de escopo, DA pode ser importante ao fornecer conhecimento sobre o consumidor e permitir a personalização das ofertas ao cliente (EIRINAKI \& VAZIRGIANNIS, 2003).

Outra possibilidade de DA gerar conhecimento estratégico é através da inteligência competitiva, que é o monitoramento dos concorrentes e de pontos fortes e fracos da própria empresa (TARAPANOFF 2004). Através de pesquisas de mercado, é possível rastrear os hábitos de navegação dos internautas no site dos concorrentes e compará-los com estatísticas de acesso da própria empresa. A análise de comentários postados pelo consumidor em mídias sociais também é um termômetro da opinião sobre a marca (LIMA et al., 2005; CUI \& GUO, 2009) baseada no conhecimento gerado pelo consumidor (GIBBERT et al., 2002).

\subsection{Problemática do Digital Analytics}

Apesar de ser um conceito promissor que pode agregar valor aos negócios, existem diversas barreiras que não permitem que se alcance o máximo proveito das métricas para os negócios:

- As métricas online não estão alinhadas à estratégia de negócios (KAUSHIK, 2009).

- A análise técnica do clique stream nos sites não considera o consumidor como o centro das análises (KAUSHIK, 2009; ARUN et al., 2006) .

- Uma série de web métricas infla os relatórios aumentando a dificuldade para obter insights de negócios (STERN, 2010), (ARUN et al, 2006) . 
- Há falta de dados qualitativos resultando em dificuldades para tomar decisões que exijam um conhecimento maior sobre o consumidor (BUGHIN et al, 2008; KAUSHIK, 2009).

- A necessidade de integração entre dados de ações online e offline para melhorar os resultados de empreendimentos corporativos como campanhas e novos produtos (BUGHIN et al, 2008; SHANKAR \& YADAV, 2010).

Além dos problemas citados na literatura, a própria pesquisa bibliográfica é comprometida pelo teor comercial do conceito de DA. Numa busca à base de pesquisas ISI Web of Knowledge (2010) foram encontrados apenas 7 resultados relacionados, sendo que 4 são referências a patentes. Normalmente o conceito de DA aparece de forma implícita, distribuído numa terminologia especifica, onde se destacam os seguintes temas: Web Mining, Web Semantics e Web Personalization.

Portanto, a própria delimitação do conceito de DA é um problema, haja vista, os temas correlatos e as diversas áreas do conhecimento que fazem interface com esse assunto. Se por um lado, a incorporação desses temas pode ampliar e fortalecer o conceito de DA, por outro lado, pode dispersar os esforços da pesquisa e torná-la menos objetiva.

\subsection{Questões e objetivos}

O principal objetivo da pesquisa é entender como as empresas utilizam o conceito de DA e elencar fatores críticos para que elas possam obter máximo proveito de uma implantação de DA.

A partir desse objetivo macro foram detalhados diversos objetivos específicos para facilitar o planejamento da pesquisa:

i. Montar um framework de DA a partir dos constructos identificados na literatura

ii. Verificar empiricamente a aplicação desse framework nas empresas brasileiras

iii. Avaliar o alinhamento estratégico de DA e sua eficácia para os negócios

iv. Identificar os principais elementos de sucesso na implantação de DA 
Dentro desse contexto, a pesquisa visa esclarecer as seguintes questões:

Q1. Como e porque as empresas aplicam os conceitos de DA em seus negócios?

Q2. Como é feito o alinhamento estratégico entre DA e os negócios?

Q3. De que forma DA pode aumentar a criação de valor estratégico?

\subsection{Metodologia}

O primeiro passo da pesquisa será uma ampla pesquisa bibliográfica para delimitar os constructos de DA e determinar seu potencial estratégico, culminando num framework de análises que será utilizado posteriormente na pesquisa de campo.

Também serão identificados na literatura, alguns casos de aplicação do conceito de DA, assim como os problemas e êxitos identificados nesses empreendimentos.

A pesquisa de campo será dividida em duas etapas: num primeiro momento, será realizada uma survey exploratória para mensurar a frequência de utilização das aplicações de DA.

$\mathrm{Na}$ sequencia, serão realizados estudos de caso que ampliarão o entendimento de como são realizadas as implantações de DA e por que ocorrem esses problemas reconhecidos na literatura. Ao se compreender as causas desses problemas, será proposta uma metodologia que mitigue esses pontos fracos e explore o potencial estratégico do conceito de DA.

\subsection{Estrutura da pesquisa}

Os conteúdos da pesquisa foram ordenados de forma que possibilitem o entendimento das questões propostas.

Neste capítulo introdutório, foram apresentados a justificativa, os objetivos, as questões da pesquisa e a forma como a pesquisa será realizada.

No capítulo 2, a "Evolução da Internet e seus impactos para a sociedade", foi traçado um panorama da Internet no Brasil e no mundo e como essa nova tecnologia tem transformado as relações pessoais e as formas de se fazer negócios. 
O foco do capítulo 3 "O papel estratégico da Internet" foi explorar a forma como a $\mathrm{TI}$ e, mais especificamente, a Internet tem influenciado a estratégia das empresas e mudado o jogo competitivo.

No capítulo 4, "Digital Analytics", foi realizada uma síntese dos diversos conceitos relacionados à DA e será verificado o estado da arte da aplicação de DA. Também serão estudadas as análises mais comuns de DA, assim como, sua relação com elementos da gestão de negócios.

No capítulo 5, "Metodologia", foi explanado o planejamento da pesquisa de campo, detalhando-se as empresas que serão analisadas e sua relevância, as proposições que serão verificadas e o protocolo que será seguido nos estudos de caso.

No capítulo 6, "Pesquisa exploratória", são apresentados resultados preliminares da pesquisa onde se procura entender qual o alcance da aplicação de DA nas empresas brasileiras e quais temas mais frequentes entre os profissionais de DA. 


\section{Evolução da Internet e os impactos nos negócios e na sociedade}

\subsection{Revoluções tecnológicas}

Segundo Castells (1999), a tecnologia transforma a sociedade de forma disruptiva, assim como ocorreu na evolução das espécies. Enquanto a revolução industrial pode ser considerada como uma mudança nas ferramentas necessárias para produção dos ativos, a tecnologia da informação (TI) muda os processos da sociedade, transforma as estruturas de troca de informação e até mesmo de poder, de forma que o desenho futuro de como a sociedade será organizada torna-se uma incógnita, uma consequência imprevisível de um modelo altamente flexível e adaptável.

Para esse autor, a revolução industrial foi influenciada pela transformação das fontes de energia e e seu impacto na linha de produção, como, por exemplo, às máquinas a vapor e posteriormente a energia elétrica. No tocante às relações de poder, não houve maiores mudanças na estrutura da sociedade após a revolução industrial, prevalecendo a estrutura hierárquica, sendo inclusive reforçada pela repetição exaustiva de procedimentos e alienação do ser humano no processo de trabalho. No entanto, notou-se evolução na qualidade de vida da sociedade, sendo que essa mudança dá-se com maior impacto nas sociedades onde há relação intensa entre locais de inovação, produção e utilização das novas tecnologias.

Ainda segundo Castells (1999), a revolução tecnológica é baseada na evolução da capacidade de processamento, de acordo com a lei de Moore, microchips terão dobrado sua capacidade de processamento a cada período de 18 meses. Essa capacidade aumenta cada vez mais as aplicações possíveis e junto com a indústria de software, acaba transformando uma infinidade de processos uma vez que a informação permeia quase toda a atividade humana. Alguns fatores são característicos dessa evolução, como a formação de novos centros de inovação, como o Vale do Silício, próximo à universidade de Stanford e com a presença de diversos empreendedores cujos inventos são complementares. Detalhe curioso, segundo Castells (1999), interações informais em bares e 
restaurantes foram classificadas como mais importantes que os seminários de Stanford para inovação, representando a importância das redes sociais mesmo antes dessas redes existirem na Internet.

\subsection{Evolução da Internet e relevância para sociedade}

\subsubsection{Histórico da Internet}

Uma das tecnologias que mais tem modificado a sociedade é a Internet. A princípio uma rede militar que interligava os servidores do departamento de defesa americano, transformou-se numa rede com objetivos acadêmicos e na década de 1990, deu-se início a era comercial da grande rede.

Uma série de operações de e-business e sites voltados ao usuário final ganharam mercado facilmente, empolgando investidores e levando ao questionamento de modelos de negócios tradicionais. Tamanho otimismo levou a especulação demasiada e supervalorização das ações dessas empresas, o que provocou o estouro da bolha das empresas ponto com no ano 2000.

Muitas empresas digitais quebraram e houve dúvidas com relação ao futuro do e-business, Porter (2001) avaliou que o movimento das startups era apenas especulativo e que, após a crise, as empresas voltariam a seus antigos modelos de negócios. De acordo com esse ponto de vista, o papel principal da Internet seria o de prover uma plataforma para integração do sistema de valor e possibilitar o posicionamento estratégico diferenciado.

Tapscott (2001) por sua vez reafirmou os princípios que estabelecem a Internet como uma tecnologia revolucionária para os negócios:

- A rede seria uma nova infra-estrutura para criação de riqueza e os pequenos empresários teriam papel de protagonistas nessa criação de valor.

- A Internet possibilitaria novos modelos de negócios e adicionaria novas fontes de valor ao sistema através da criação colaborativa e de uma economia focada no conhecimento.

- A informação trocada em tempo real, de forma transparente e com difícil controle pelas autoridades, influenciaria governos e estabeleceria uma nova forma de governar. 
- As universidades funcionariam como nós na rede de comunicação e conhecimento.

No ano de 2003, já era possível constatar que após a ressaca do estouro da bolha, as operações que sobreviveram geravam resultados relevantes. Se um investidor tivesse investido em todas as empresas de comércio eletrônico que lançaram suas ações na bolsa americana, incluindo as empresas que faliram, conseguir-se-ia uma rentabilidade de 35\% (BUSINESSWEEK, 2003). O valor de mercado de empresas digitais com capital aberto como Google $U \$ 135$ bi e Amazon U\$ $99 \mathrm{bi}$, assim como o valor de empresas que fornecem produtos e serviços relacionados à Internet como a Apple, U\$ 355 bi, indicam a saúde financeira do segmento (NASDAQ, 2011).

A partir de 2005, aplicações da chamada web 2.0 que permitem a edição e publicação do conteúdo pelo próprio usuário como blogs, redes sociais e wikis disseminaram-se na Internet. Ampliando as possibilidades de criação de valor através da colaboração (TAPSCOTT \& WILLIAMS, 2007). Houve a geração de novos modelos de negócios que pode ser visualizada em alguns mercados como o fonográfico, onde artistas prescindem das gravadoras, divulgando suas obras através da Internet e obtendo recursos através de mecanismos de financiamento coletivo (FERRAZ \& PRETO, 2011). A influência das trocas de mensagens através nas redes sociais também pode ser notada na transformação na relação dos cidadãos com os governos verificada nas revoluções no Oriente Médio (TAPSCOTT, 2011).

A gestão do conhecimento gerado pelos usuários na Internet é pauta obrigatória para as empresas, pois influencia diretamente o relacionamento com o consumidor (GIBBERT et al., 2002). Para Lafuente (2011), o raciocínio digital atrelado a esse conhecimento através de ferramentas de Data Mining e personalização automática do conteúdo é considerada como uma nova era da Internet, a Web 3.0.

Em 2012, problemas no lançamento das ações em bolsa do Facebook colocaram novas dúvidas sobre a viabilidade das empresas. Alguns analistas questionam a expectativa de faturamento com anúncios na Internet, comparando a com uma nova bolha (INGRAM, 2012). Porém, nota-se que se trata de um caso particular. Além de problemas na condução da Initial Public 
Offering (IPO), os anunciantes consideram que os anúncios nessa rede social geram retorno baixo, pois se entende que durante o uso da rede o usuário busca principalmente o entretenimento, dificultando o interesse pelo conteúdo das mensagens publicitárias. Outro problema é a ausência de uma solução para publicidade para dispositivos mobile que são cada vez mais representativos na audiência do site.

A hipótese de uma nova bolha se enfraquece, pois há outras empresas digitais que apresentam resultados sólidos: o valor de mercado de empresas digitais com capital aberto como Google U\$243 bi e Amazon U\$ 113 bi, assim como o valor de empresas que fornecem produtos e serviços relacionados à Internet como a Apple, U\$ 596 bi, indicam a saúde financeira do segmento (NASDAQ, 2012). Essas empresas possuem estratégias baseadas em inovação, são competitivas e geram lucros há vários anos.

A transformação na economia provocada pela Internet pode ser verificada através dos critérios propostos por Evans \& Wurster (1999): alcance, riqueza de informações e afiliação.

\subsubsection{Alcance da Internet}

O alcance da Internet mundial é de 2,1 bilhões de usuários, ou seja, 30\% da população mundial possui acesso à Internet. Quando analisado o total de internautas por país (figura 2.1), vê-se que a China já é o país com maior número de internautas, e que outros países emergentes como Brasil e Índia já ocupam lugar de destaque. Nota-se também que esses países foram os que mais contribuíram para o crescimento da Internet nos últimos 10 anos, tendência que deve persistir haja vista o potencial da população desses países que ainda não possui acesso à Internet e que nos próximos anos deve estar conectada (figura 2.2) (INTERNET WORLD STATS, 2011). 


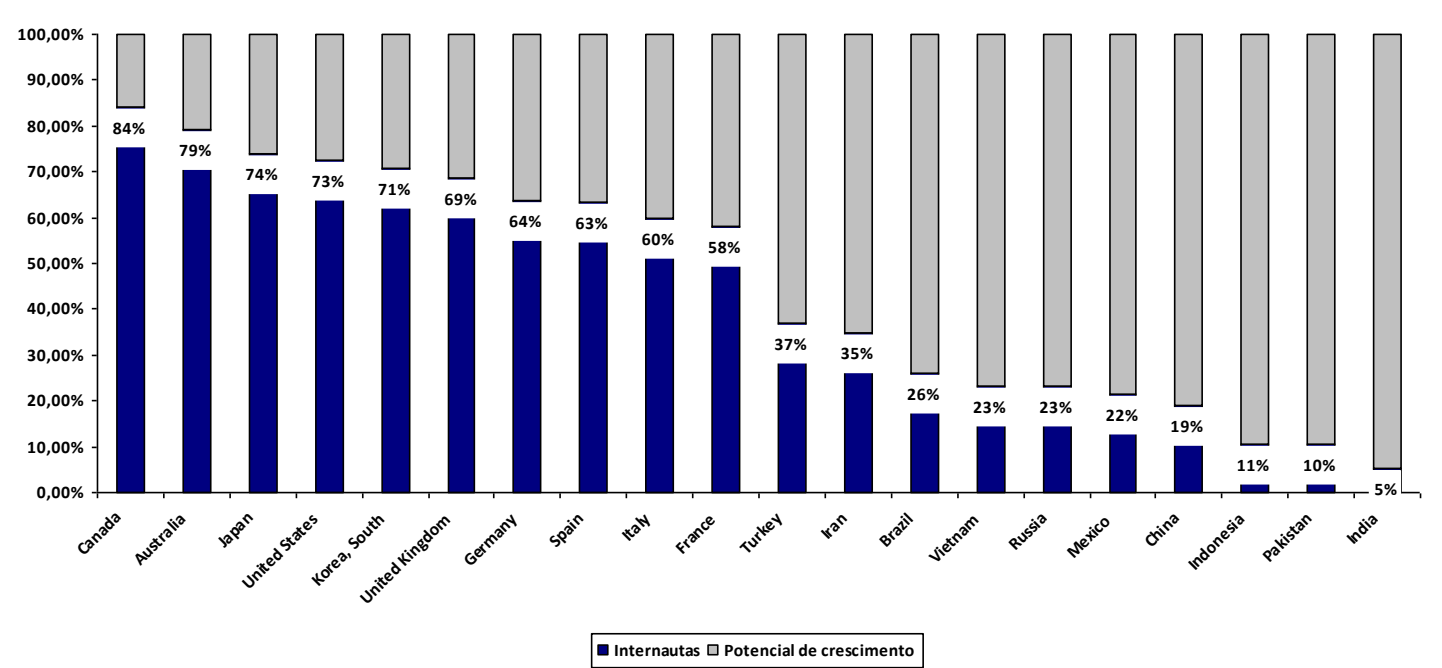

Figura 2.1: Distribuição dos internautas nos países com maior audiência no mundo (adaptado de INTERNET WORLD STATS, 2011)

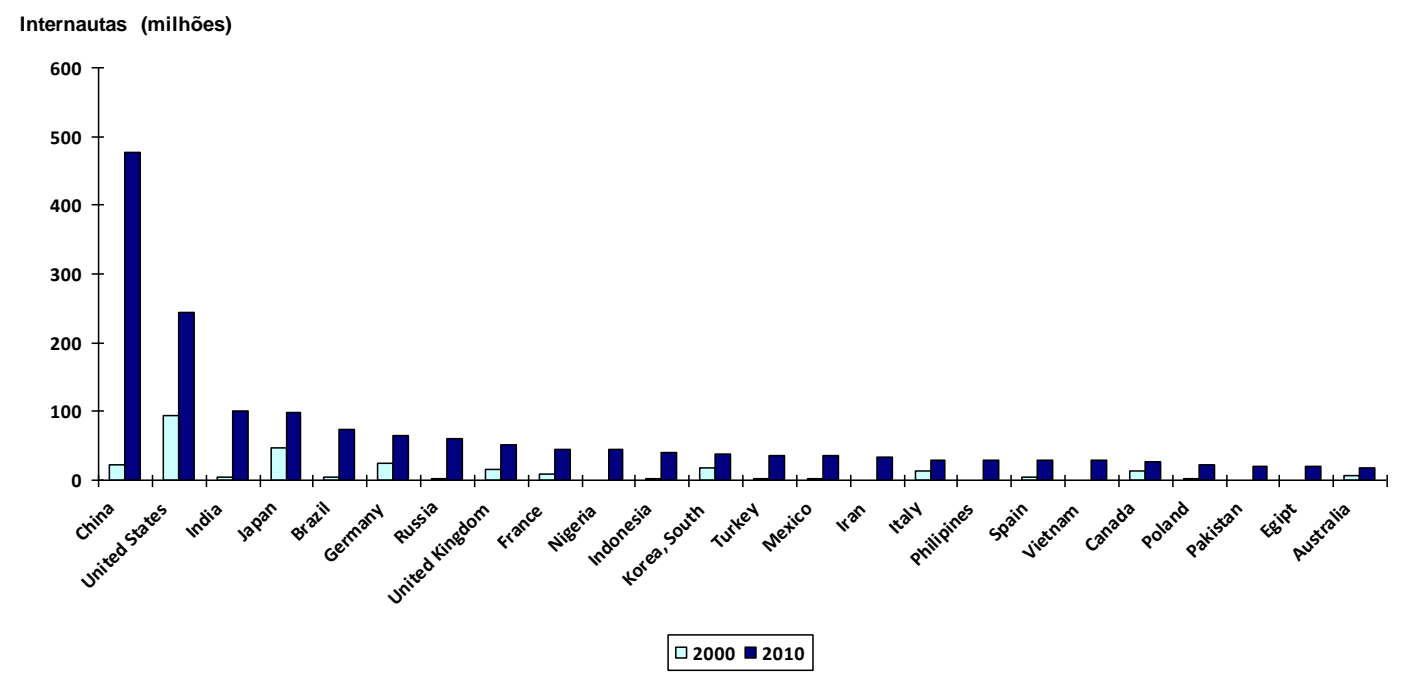

Figura 2.2: Participação dos internautas sobre total da população (adaptado de INTERNET WORLD STATS, 2011)

O crescimento das mídias digitais é mais acelerado do que o observado outros meios, por exemplo, a TV e o Rádio levaram mais de 20 anos para chegarem a 50 milhões de usuários. A Internet levou apenas 4 anos para atingir esse total, sendo que o Facebook levou apenas 1 ano para atingir 200 milhões de pessoas (MOL - MARKETING ONLINE, 2011).

No Brasil, verifica-se fenômeno semelhante com a inclusão digital da população de menor renda. Até o ano de 2006, a Internet brasileira apresentava um volume estável de 33 milhões de internautas, número equivalente ao total de pessoas das classes $A$ e $B$. Nos últimos anos, há um crescimento expressivo dos internautas, chegando a 74 milhões em 2010 
(figura 2.3). Essa expansão deve-se a programas de inclusão digital, acesso em locais públicos como lan houses e facilidade de crédito que fez aumentar as vendas de computadores. A inclusão digital também mudou o perfil dos internautas, 53\% deles pertencem às classes C, D e E (IAB BRASIL, 2011).

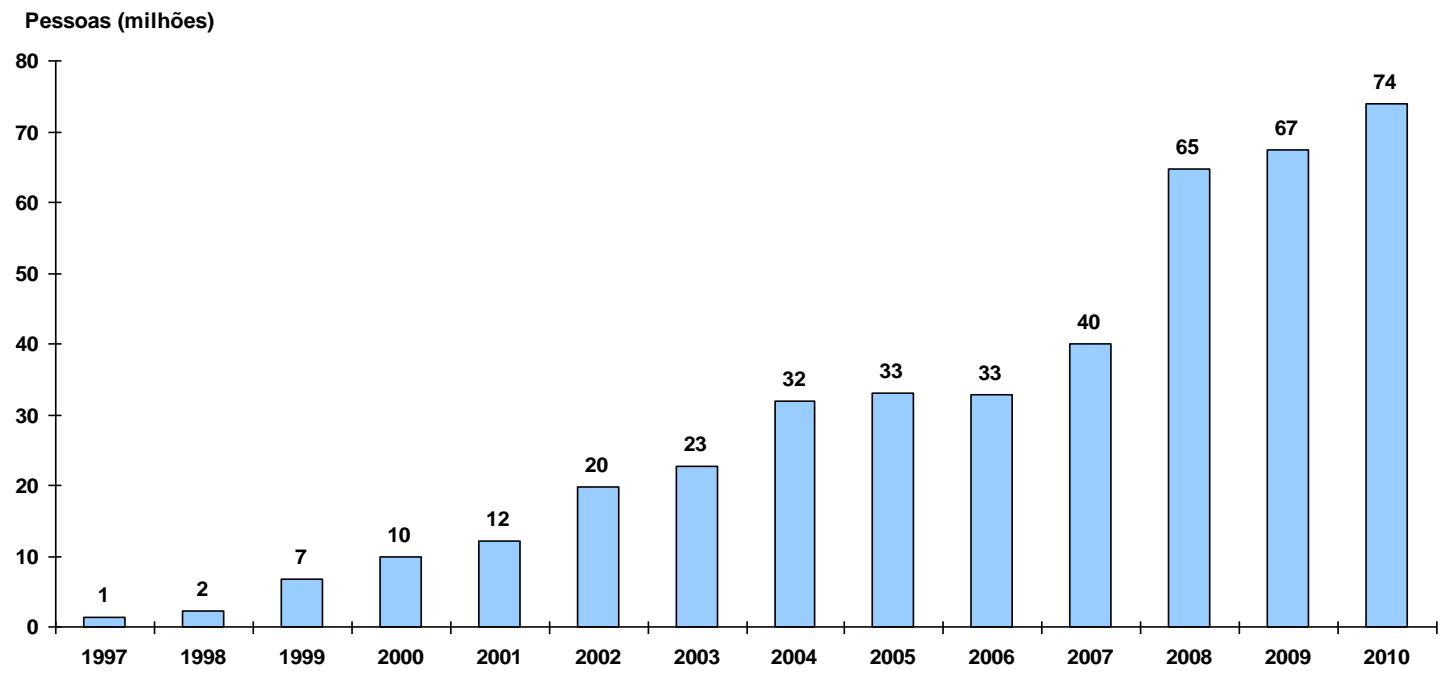

Figura 2.3: Evolução dos internautas no Brasil (Dados extraídos de IAB BRASIL, 2011) A popularização de dispositivos móveis com acesso à Internet também contribui para essa disseminação. No Brasil, $41 \%$ dos proprietários de celular acessam a Internet e 19\% acompanham programas de TV pelo telefone. 30\% dos celulares brasileiros são smatphones, $50 \%$ são convencionais e $20 \%$ ficam numa linha tênue, pois apesar de não serem smartphones, possuem funcionalidades avançadas como Wi-Fi, GPS, tela touch e acesso à Internet e TV. Aparelhos com essas características podem ser encontrados por preços entre $R \$ 70,00$ e $R \$ 120,00$, popularizando o acesso a todas as classes e facilitando a inclusão digital (CAVALLINI \& REIS, 2011).

\subsubsection{Riqueza das informações}

Além do enorme alcance das aplicações de Internet, a riqueza de informações (EVANS \& WURSTER, 1999) também impressiona. O volume de informações publicadas ultrapassa com folga outras mídias, o Wikipedia, por exemplo, concentra 3,7 milhões de verbetes na língua inglesa versus 225.274 tópicos da enciclopédia britânica (WIKIPEDIA, 2011). Estudo da agência MOL - Marketing Online (2011) revela o volume de conteúdo produzido na Internet: 
- Existem mais de 255 milhões de websites em todo o mundo, 21 milhões foram ao ar em 2010;

- Há mais 100 milhões de vídeos cadastrados no Youtube. Em apenas 2 meses, foram publicados mais vídeos no Youtube que toda a produção gerada pela ABC, NBC e CBS desde 1948. $70 \%$ dos internautas entre 18 e 34 anos já assistiram TV pela Internet, sinalizando que dispositivos conectados à Internet podem até substituir a TV;

- Existem mais de 152 milhões de blogs na Internet, sendo que 50\% dos blogueiros postam conteúdo diariamente.

Esses números são fruto de uma nova lógica na produção de conteúdo conhecida como Web 2.0. Através desse novo paradigma, o usuário produz o conteúdo colaborativamente e o publica de forma gratuita. Segundo Tapscott e Williams (2007), essa colaboração que será mais importante para a economia do que a competição e o direito à propriedade intelectual.

\subsubsection{Afiliação}

O último pilar citado por Evans \& Wurster (1999) para avaliação do valor criado na Internet é a afiliação. Através desse conceito, usuários trocam informações e forma opinião sobre política, moda, estilo, marcas, serviços e produtos. Impulsionando.

Castells (2003) verifica que a formação de redes é tradicional nas sociedades humanas e vislumbra que a Internet pode amplificar essas redes e renovar seu uso, podendo funcionar como ferramenta de organização. $O$ advento de redes sociais na Internet como o Facebook, surgido em 2004, comprova esse insight. Essa rede que originalmente conectava estudantes da universidade de Harvard, possui mais de 750 milhões de usuários em 2011. Em média, cada usuário possui 130 amigos conectados, ampliando significativamente a capacidade de interação das pessoas envolvidas (FACEBOOK, 2011).

As redes sociais têm sido instrumentos importantes em movimentos sociais recentes como as revoluções no oriente médio, principalmente o Twitter que permite o compartilhamento de mensagens curtas de até 140 caracteres, o que facilita seu uso a partir de celulares. Essas redes permitem a troca de 
informações táticas como a divulgação dos locais para manifestações e denúncias de execuções realizadas pelas forças militares. Em entrevista concedida à Muller (2011), Don Tapscott declarou que: "No caso do Oriente Médio, a Internet foi uma arma de guerra e uma ferramenta de revolução que ajudou a denunciar o assassinato de centenas de cidadãos"

\subsection{Impacto da Internet nos negócios}

\subsubsection{O e-business na Internet brasileira}

A Internet é a base para o e-commerce e o e-business, esses conceitos transpõem o aspecto tecnológico, pois possibilitam mudanças profundas na organização dos negócios (GEREFFI, 2001).O e-business envolve todas as ações online que impactam nos negócios da empresa, enquanto o e-commerce aborda as transações comerciais pela Internet. Além do e-commerce, o ebusiness envolve uma série de ações na Internet como: utilização de serviços (ex.: Internet Banking), pesquisas feitas pelo consumidor para comprar seus produtos, divulgação de propaganda online, entre outras formas que aparecem constantemente e que transformam a maneira de consumir.

Uma pesquisa do instituto ComScore (2011) sobre os hábitos de navegação dos internautas brasileiros, indica a expressividade dessas diferentes formas de e-business (figura 2.4). Enquanto sites de e-commerce são visitados por $70 \%$ dos internautas brasileiros, nota-se que $86 \%$ desses internautas usam mecanismos de busca para chegarem nesses sites. O que sinaliza um comportamento onde cada vez mais a pesquisa prévia na Internet é relevante para o consumo, seja através do e-commerce ou na loja física. Alguns autores afirmam que a ordem dos resultados na busca pode influenciar na escolha dos produtos, quando um determinado produto aparece na primeira página de busca, possui maior credibilidade frente ao consumidor e por isso vende mais (FOX, 2010). Atentos à essa tendência, publicitários americanos investiram $45 \%$ das verbas de campanhas online em links patrocinados que aparecem nas páginas dos mecanismos de busca (CAPPS, 2009). 

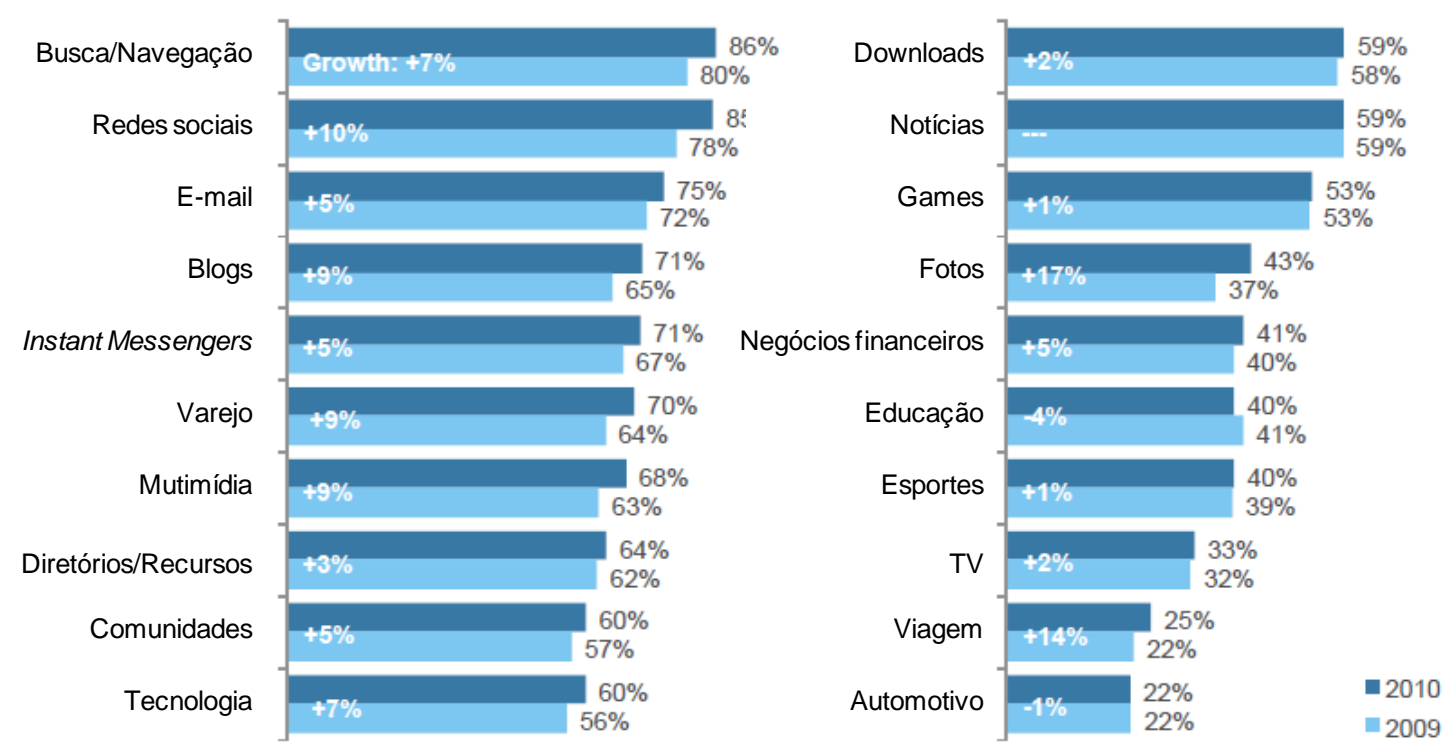

Figura 2.4: Cobertura dos internautas brasileiros por categoria (COMSCORE, 2011)

Outra tendência é quando o consumidor solicita a opinião de outros usuários antes de realizarem suas compras, o chamado varejo 2.0 (TERRA et al., 2011). Esse tipo de consulta é apoiado pela ampla base de brasileiros que possuem acesso às redes sociais, $85 \%$ segundo ComScore (2011).

Os serviços financeiros online também impressionam com $41 \%$ de cobertura, sendo que o Brasil é o país que proporcionalmente mais utiliza internet banking.

Sites educacionais, seja para pesquisas ou cursos oferecidos pela Internet ( $e$ learning), também são bastante acessados contando com $40 \%$ da base dos internautas.

A audiência dos sites do setor automotivo, visitados por $22 \%$ dos internautas, indicam que esses sites são relevantes para obtenção de informações prévias e influenciam a compra dos veículos. O mesmo acontece com o segmento de turismo com $25 \%$ de audiência: o consumidor consulta os roteiros, hotéis e companhias aéreas e realiza pesquisa de preços antes de fechar sua viagem (COMSCORE, 2011).

\subsubsection{Evolução do e-commerce brasileiro e comparativo com outros países}

Analisando especificamente os sites de e-commerce, nota-se um crescimento de 9\% na audiência de 2009 para 2010, fazendo com que esses sites chegassem a uma cobertura total de $70 \%$, o que torna o Brasil líder nesse segmento em toda a América Latina. Um impulsionador desse crescimento é 
os sites de compras coletivas como Clube Urbano, Peixe Urbano e Click On (COMSCORE, 2011).

Esse crescimento também pode ser verificado nos volumes de compra na Internet, em 8 anos houve incremento maior que $400 \%$, chegando a 25 bilhões de reais em 2010. Mais da metade deste faturamento provém de vendas relacionados a turismo e automóveis (E-CONSULTING, 2011) (Figura 2.5). No primeiro caso, vê-se uma transformação intensa no setor com algumas companhias aéreas vendendo a maioria de suas passagens pela Internet. No segmento de autos, embora seja mais rara a venda de um carro pela Internet, o faturamento relevante deve-se ao alto ticket médio relacionado à venda de veículos.

Ainda que os números apresentem evolução superior a outras indústrias, quando comparado com outros países, nota-se que o e-commerce brasileiro ainda possui um espaço considerável para crescimento. Para verificar esse fato foi feita uma análise comparativa com outros três países: China, representante da Ásia e país considerado emergente como o Brasil; Reino Unido, representante da Europa e com e-commerce em ascensão; Estados Unidos, país com e-commerce mais evoluído. Três índices foram analisados: faturamento, crescimento e concorrência.

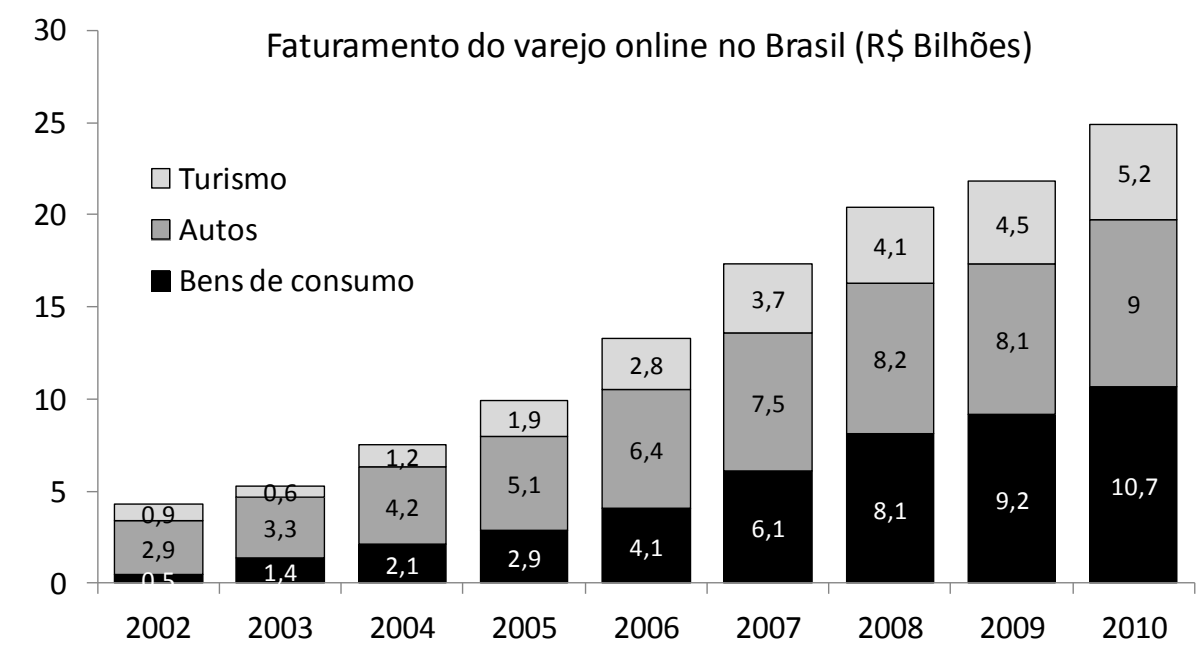

Figura 2.5: Crescimento do Varejo Online (E-CONSULTING, 2011)

O Brasil apresentou um faturamento em dólar acentuadamente menor que de outros países, mesmo se levarmos em consideração o tamanho das populações, o e-commerce brasileiro comparativamente movimenta menos dinheiro que outros países (figura 2.6). A taxa de crescimento de 2009 versus 
2008 parece razoável, está próxima à da China, embora seja menor que a do Reino Unido (figura 2.7).

Um indicador da maturidade dos mercados em e-commerce é a participação do líder do mercado. Quanto mais desenvolvido o e-commerce, mais se espera que a competição entre os agentes seja grande e o líder não consiga abocanhar uma grande fatia de mercado, no concorrido mercado americano a líder Amazon detém apenas 9\% de market share (INTERNET RETAILER, 2009). No Brasil a concentração é de $40 \%$, sinal de que ainda há espaço para adição de novos players, principalmente, os focados em mercados de nicho (IDGNOW, 2009).

Além do e-commerce $\mathrm{B} 2 \mathrm{C} / \mathrm{C} 2 \mathrm{~B}$ (business-to-consumer/consumer-to-business): que engloba as transações entre empresas e consumidores, existem diferentes formas de e-commerce, que podem ser: B2B (business-to-business): transações entre empresas; B2G/G2B (business-to-government/government-tobusiness): transações envolvendo empresas e governo, como pregões eletrônicos; C2C (consumer-to-consumer): transações entre consumidores finais, exemplo: site de leilão; G2C/C2G (government-toconsumer/consumer-togovernment): transações envolvendo governo e consumidores finais, como pagamento de tributos; G2G (government-to-government): transações entre governo e governo (Rocha et al., 2002). No Brasil, o comércio B2B envolve um volume de receita significativamente maior que o B2C, 948 bilhões versus 25 bilhões em 2010 (E-CONSULTING, 2011). Essa representatividade do comércio B2B sinaliza a importância estratégica da Internet para a estrutura dos sistemas de valor formados pelas empresas, assunto abordado no próximo capítulo. 


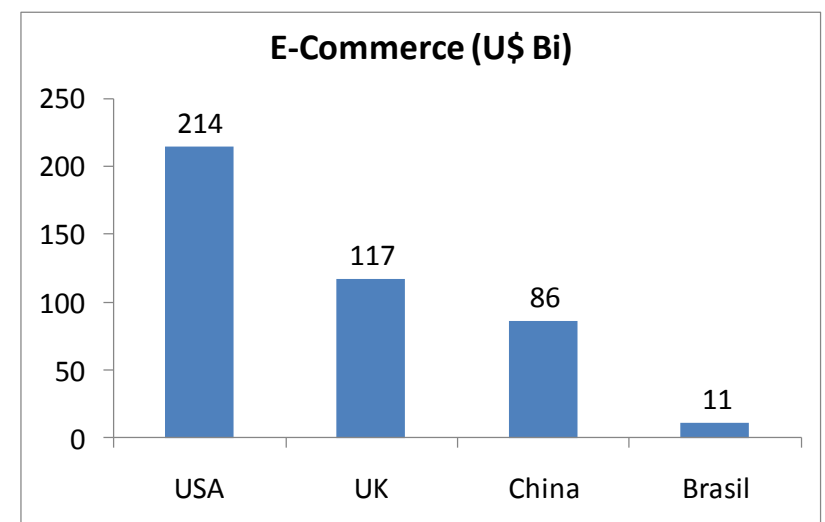

Figura 2.6: Comparativo do faturamento do e-commerce em diferentes países (Consolidado a partir de ComScore, 2009; IDC apud Hao, 2009; E-consulting, 2009; Research and Markets, 2009)

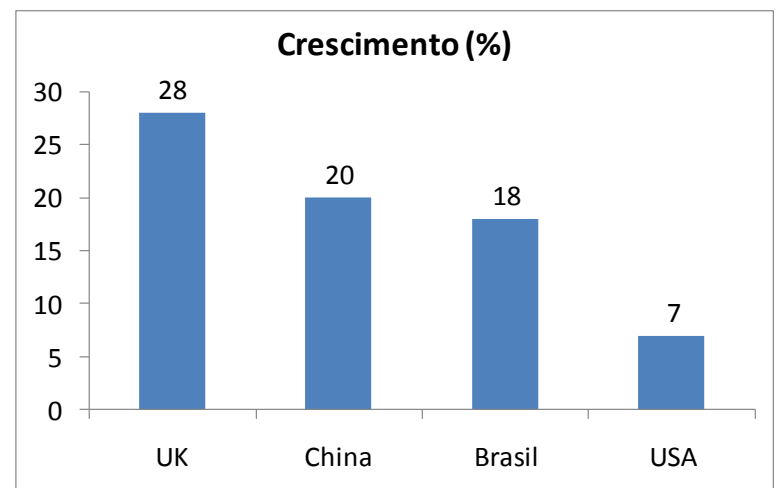

Figura 2.7: Comparativo do crescimento do e-commerce de 2009 vs 2008 em diferentes países (Consolidado a partir de ComScore, 2009; IDC apud Tao, 2009; E-consulting, 2009; Research and Markets, 2009) 


\section{Papel estratégico da Internet}

\subsection{Evolução do papel da TI nas empresas}

Zwass (1998) analisou a transformação dos negócios induzida pela tecnologia e a representou em quatro fases: (i) a fase de suporte operacional, com predomínio daautomatização de rotinas departamentais; (ii) o suporte à administração, quando gerentes passam a tirar valor das informações para tomada de decisões; (iii) o suporte à transformação do negócio, com ênfase na integração dos sistemas e aquisição de vantagem competitiva pelas empresas; (iv) a computação onipresente, momento atual em que os dispositivos móveis permitem a utilização dos sistemas de informação a partir de qualquer local (tabela 3.1).

A era IV foi possibilitada pela integração promovida pela Internet que tem transformado as cadeias de valor e o relacionamento com o consumidor como será visto adiante.

Tabela 3.1: As quatro eras da computação organizacional (Zwass, 1998)

\begin{tabular}{|c|c|c|c|c|}
\hline & $\begin{array}{c}\text { Era I } \\
\text { (meados dos } \\
50 \text { até } \\
\text { meados dos } \\
70 \text { ) }\end{array}$ & $\begin{array}{c}\text { Era II } \\
\text { (meados dos } \\
70 \text { até } \\
\text { meados dos } \\
80 \text { ) } \\
\end{array}$ & $\begin{array}{c}\text { Era III } \\
\text { (meados dos } \\
80 \text { até meados } \\
\text { dos } 90 \text { ) }\end{array}$ & $\begin{array}{c}\text { Era IV } \\
\text { (meados dos } \\
90 \text { até hoje) }\end{array}$ \\
\hline Descrição & $\begin{array}{c}\text { Suporte } \\
\text { operacional }\end{array}$ & $\begin{array}{c}\text { Suporte à } \\
\text { administração } \\
\text { e a trabalhos } \\
\text { de } \\
\text { conhecimento }\end{array}$ & $\begin{array}{c}\text { Suporte à } \\
\text { transformação } \\
\text { do negócio e à } \\
\text { competição }\end{array}$ & $\begin{array}{l}\text { Computação } \\
\text { onipresente }\end{array}$ \\
\hline $\begin{array}{l}\text { Objetivo } \\
\text { primário }\end{array}$ & $\begin{array}{l}\text { Suporte a } \\
\text { operações }\end{array}$ & $\begin{array}{c}\text { Suporte à } \\
\text { administração }\end{array}$ & $\begin{array}{l}\text { Melhoria na } \\
\text { posição } \\
\text { competitiva } \\
\end{array}$ & $\begin{array}{l}\text { Integração } \\
\text { eletrônica }\end{array}$ \\
\hline $\begin{array}{l}\text { Clientes } \\
\text { primários }\end{array}$ & $\begin{array}{c}\text { Grandes } \\
\text { unidades } \\
\text { corporativas }\end{array}$ & $\begin{array}{l}\text { Gerentes e } \\
\text { profissionais }\end{array}$ & $\begin{array}{l}\text { Unidades de } \\
\text { negócio }\end{array}$ & $\begin{array}{l}\text { Equipes de } \\
\text { colaboração }\end{array}$ \\
\hline Justificativa & Eficiência & $\begin{array}{l}\text { Eficácia } \\
\text { gerencial }\end{array}$ & $\begin{array}{c}\text { Fatia de } \\
\text { mercado e } \\
\text { lucratividade }\end{array}$ & $\begin{array}{c}\text { Eficácia } \\
\text { organizacional }\end{array}$ \\
\hline Fonte & $\begin{array}{l}\text { Processament } \\
\text { o de dados } \\
\text { individual ou } \\
\text { departamento } \\
\text { de sistemas } \\
\text { de informação }\end{array}$ & $\begin{array}{l}\text { Unidades de } \\
\text { sistemas de } \\
\text { informação e } \\
\text { usuários finais }\end{array}$ & $\begin{array}{c}\text { Coordenada } \\
\text { dentro da } \\
\text { organização/ } \\
\text { Computação } \\
\text { voltada para o } \\
\text { usuário final }\end{array}$ & $\begin{array}{c}\text { Estrutura de } \\
\text { computação } \\
\text { própria e } \\
\text { terceirizada }\end{array}$ \\
\hline
\end{tabular}

Porter \& Millar (1985) afirmam que a TI muda a forma como as empresas competem. Foram identificadas três formas em que a TI afeta a competição: (i) 
alterando a estrutura da indústria, uma vez que pode influenciar cada uma das cinco forças (PORTER, 1979) (ii) apoiando estratégias genéricas de diferenciação e liderança em custos; (iii) criando negócios inteiramente novos. Essas alterações são provenientes de mudanças nas cadeias de valor corporativas, que são o conjunto de ligações entre as diversas atividades da empresa que são interdependentes (figura 3.1). Ao expandir essas modificações para o relacionamento com outras empresas e clientes, ocorre a transformação de todo o sistema de valor (figura 3.2) provocando evoluções na estrutura da indústria.

\begin{tabular}{|c|c|c|c|c|c|c|c|}
\hline \multirow[t]{5}{*}{ Atividades - Meio } & $\begin{array}{l}\text { Infra-estrutura } \\
\text { empresarial }\end{array}$ & & & & & & \\
\hline & $\begin{array}{l}\text { Gerenciamento de } \\
\text { recursos humanos }\end{array}$ & & & & & & \\
\hline & $\begin{array}{c}\text { Desenvolvimento } \\
\text { de tecnologias }\end{array}$ & & & & & & \\
\hline & $\begin{array}{l}\text { Aquisição de } \\
\text { insumos }\end{array}$ & & & & & & \\
\hline & Atividades-fim & $\begin{array}{c}\text { Logística } \\
\text { interna }\end{array}$ & Operações & $\begin{array}{c}\text { Logística } \\
\text { externa }\end{array}$ & $\begin{array}{l}\text { Marketing e } \\
\text { vendas }\end{array}$ & $\begin{array}{l}\text { Prestação } \\
\text { de serviços }\end{array}$ & Margem \\
\hline
\end{tabular}

Figura 3.1: Cadeia de valor (Porter \& Millar, 1985)

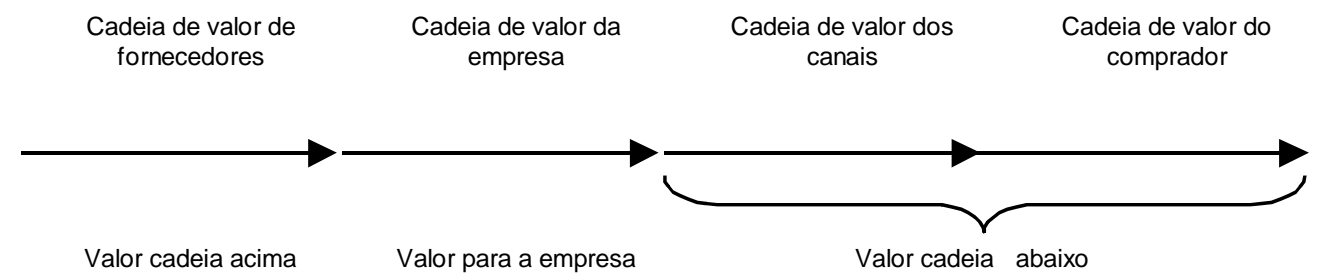

Figura 3.2: Sistema de valor (Porter \& Millar, 1985)

\subsection{Alinhamento entre TI e estratégia corporativa}

Segundo Mintzberg \& Lampel (1999) existem diversas escolas de pensamento sobre a estratégia corporativa: design, planejamento, posicionamento, empreendedorismo, cognitivo, aprendizado, poder, cultural, ambiental e configuração. Cada escola contribui de forma diferente no processo de formulação da estratégia: 
- Design: busca uma perspectiva estratégica visualizando um futuro próximo;

- Planejamento: programa a execução de uma estratégia definida a partir de uma perspectiva de futuro imediato;

- Posicionamento: a formulação da estratégia acontece através de análise de fatos históricos dentro de um horizonte definido;

- Empreendedorismo: olha para o futuro distante, na busca de uma visão única;

- Cognitivo: o pensamento do formulador da estratégia está no centro do processo de formulação da estratégia;

- Aprendizado: olhar para o detalhe, na busca das raízes dos fatos;

- Poder: foca nos pontos escondidos dentro de uma organização;

- Cultural: olha para o processo, dentro das perspectivas subjetivas das crenças;

- Ambiental: visualiza o processo como um todo, dentro da perspectiva do ambiente;

- Configuração: olha para o processo de uma maneira mais ampla, perscrutando todos os aspectos.

Baseado no papel cada vez mais relevante da TI nas organizações, diversos autores defendem o alinhamento entre as estratégias de negócios e a TI (ROCKART, 1979; PORTER \& MILLAR, 1985, HENDERSON \& VENKATRAMAN, 1993; PORTER, 2001; LAURINDO, 2008).

Rockart (1979) foi precursor ao enfatizar a importância das aplicações de TI serem derivadas dos fatores críticos de sucesso (FCSs) da empresa. Ligar sistemas de informação aos negócios da empresa. $O$ autor cita uma série de vantagens relacionadas à utilização do método dos FCSs:

- Auxiliar na priorização dos fatores a serem gerenciados

- Permitir a visualização de alternativas para melhorar funções essenciais da empresa

- Forçar gerentes a desenvolver boas medições para os FCS

- Restringir compilação dos dados àquilo que realmente é necessário 
- Evitar que construção dos sistemas seja limitada apenas aos dados fáceis de coletar

- Admitir que sistemas de informação gerenciais (SIG) devem ser ajustados frequentemente para acomodar alterações na estratégia da organização, no ambiente ou na estrutura organizacional

Laurindo (2008) ressalta a necessidade de a TI estar voltada para a eficácia, ou seja, deve estar focada no resultado para os negócios e não ser apenas um indutor de eficiência nas operações. Para alcançar essa eficácia é necessário que a TI esteja alinhada estrategicamente com os negócios. Luftman (2003) indica cinco níveis de maturidade para que ocorra esse alinhamento:

- Nível 1: Inicial - Nesse estágio, o nível de alinhamento estratégico é baixo, sendo difícil alcançar bons resultados mesmo que os investimentos sejam significativos;

- Nível 2: Comprometimento com o processo - O início da estruturação de processos de alinhamento ocorre nesse estágio, ainda que organizado por departamentos. Há mais consciência da limitação da aplicação da TI nos negócios.

- Nível 3: Processos estabilizados - A empresa possui maior maturidade no alinhamento revelada em sua governança, gestão por processos e da comunicação. Há um entendimento razoável do negócio pela estrutura de TI.

- Nível 4: Melhoria no gerenciamento de processos - Os investimentos em TI geram retornos, há uma compreensão plena de TI pelo negócio e vice-versa.

- Nível 5: Processos otimizados - As organizações nesse nível possuem alto grau de alinhamento estratégico. O planejamento da TI faz parte do planejamento estratégico do negócio.

A forma como ocorre a execução e o controle da TI são relevantes para entender o alinhamento entra a $\mathrm{Tl}$ e a estratégia. O grau de descentralização dessas atividades na operação e desenvolvimento dos sistemas explica como a TI está estruturada para apoiar a estratégia (BUCHANAN \& LINOWES, 1980). 
De acordo com o modelo de alinhamento (figura 3.3) de Henderson e Venkatraman (1993), há quatro formas de alinhamento entre TI e negócios de acordo com o modelo adotado por cada empresa (figura 3.4):

- Execução da estratégia: quando a estratégia de negócios é determinante e TI participa da execução;

- Transformação tecnológica: quando a estratégia de negócios alinhada com estratégia de TI contribui para mudanças estruturais baseadas numa visão tecnológica

- Potencial competitivo: estratégia de TI determinante, essa perspectiva visa à liderança nos negócios.

- Nível de serviços: quando o foco da estratégia de TI é a satisfação do usuário, normalmente aplicado em prestadores de serviço de TI (ex.: hosting de sites)

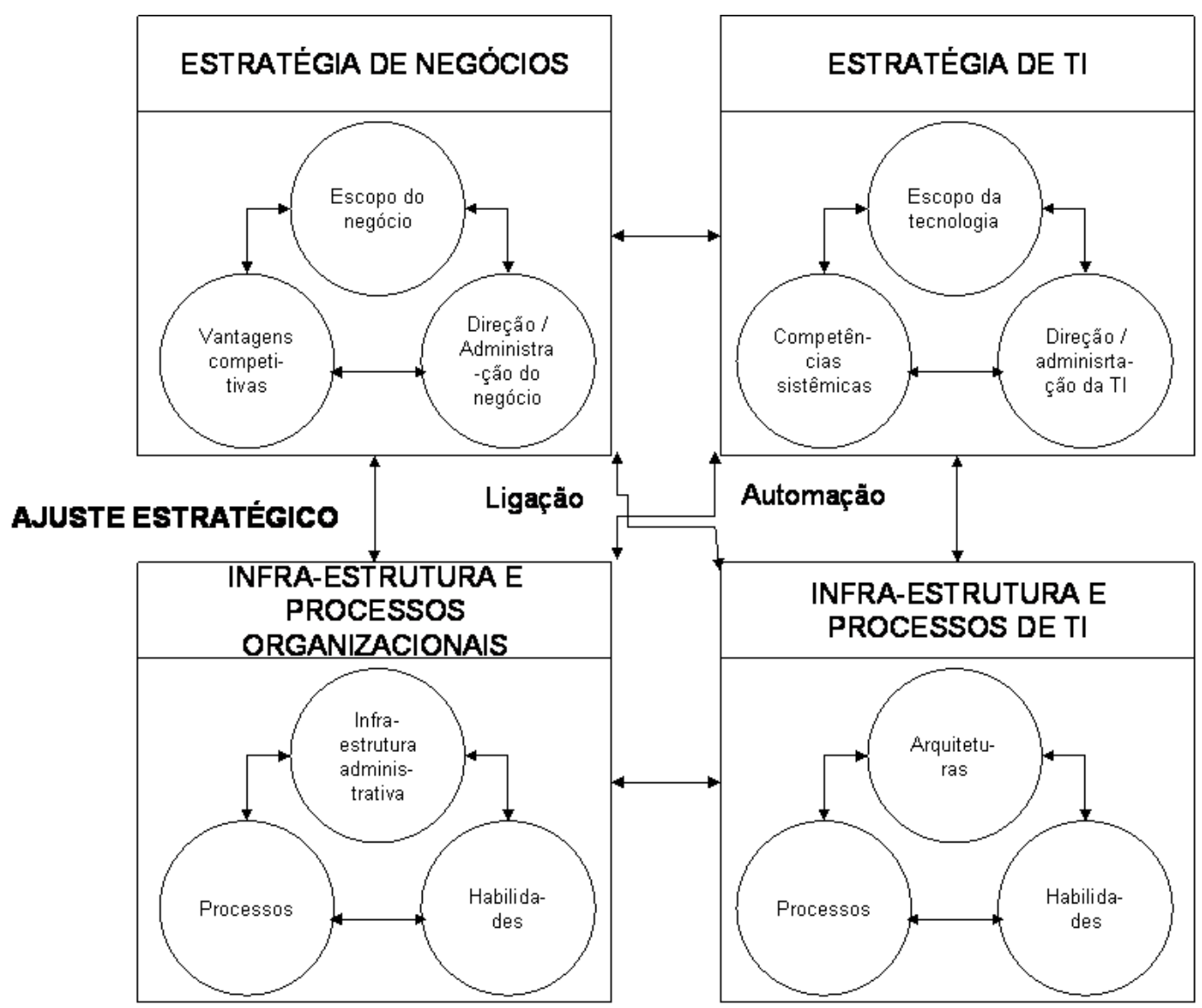

AJUSTE FUNCIONAL

Figura 3.3: Modelo do alinhamento estratégico (adaptado de Henderson \& Venkatraman, 1993) 


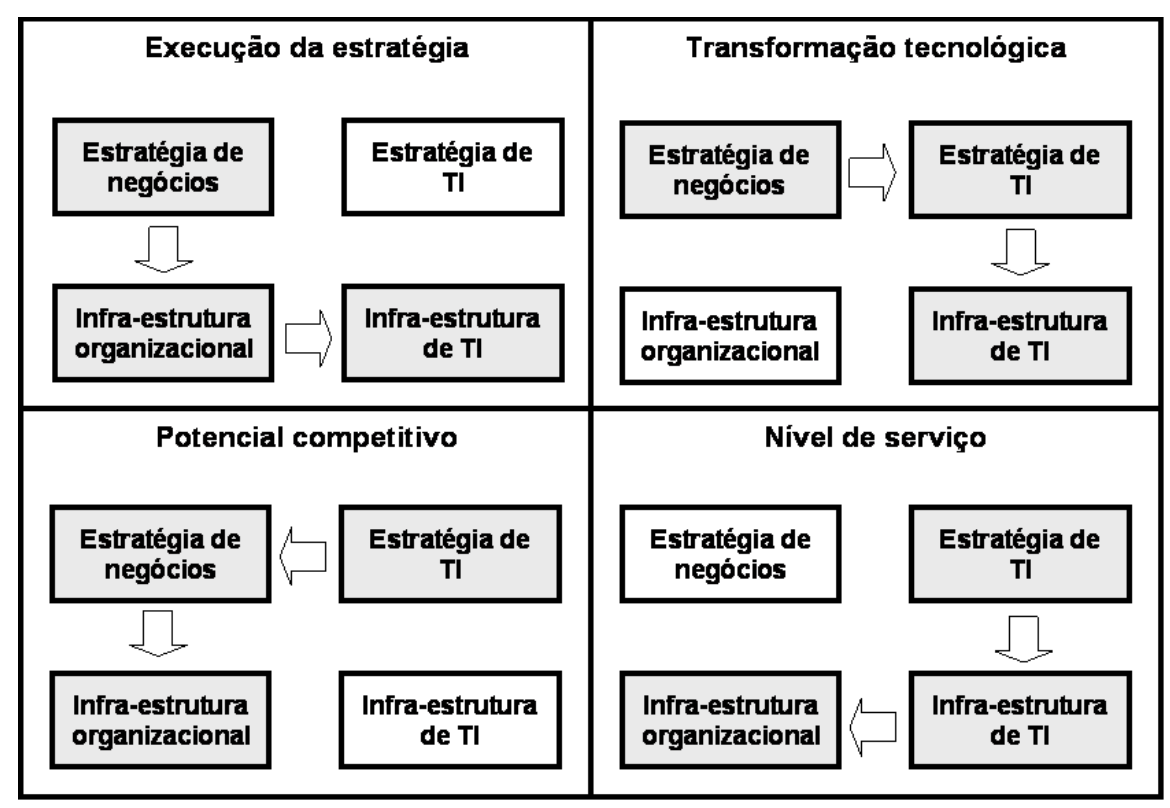

Figura 3.4: Perspectivas do alinhamento estratégico (adaptado de Henderson \& Venkatraman, 1993)

\subsection{Contribuições da Internet para a estratégia corporativa}

Existem diversas maneiras de se considerar o impacto da Internet nos negócios, a forma mais direta é acompanhar o faturamento trazido pelas operações na Internet.

As alterações nos sistemas de valor descritas anteriormente provocaram uma série de implicações para as estratégias corporativas cujos efeitos ainda não podem ser completamente avaliados.

Desde o advento da Internet, diversos autores investigam sua possível relação com a estratégia corporativa, dentre essas pesquisas destacam-se as seguintes contribuições que serão detalhadas nesse capítulo:

- A Internet como plataforma de integração do sistema de valor (PORTER, 2001)

- As implicações da virtualidade nos negócios (ANGHERN, 1997);

- A cadeia de valor virtual (CHANDRASHEKAR \& SCHARY, 1999; RAYPORT \& SVIOKLA, 1995);

- Os modelos de criação de valor específicos para o e-business (AMIT \& ZOTT, 2001).

- As redes de valor entre as empresas (BOVET \& MARTHA, 2001);

- O customer knowledge management (GIBBERT et al., 2002); 
- A co-criação de produtos e serviços (PRAHALAD \& RAMASWAMY, 2000, 2004; GIBBERT 2002; TAPSCOTT \& WILLIAMS, 2007; PRAHALAD \& KRISHNAN, 2008).

- A teoria da cauda longa que demonstra o desenvolvimento de ofertas para mercados cada vez mais segmentados (BRYNJOLFSSON, 2003; ANDERSON, 2006), facilitando a adoção de estratégias diferenciadas (KIM, 2005).

\subsubsection{A Internet como integradora do sistema de valor}

Porter (2001) acredita que a Internet acentua as ligações do sistema de valor, sendo a melhor plataforma para integração dos negócios. Segundo o autor, essa integração ocorre, pois a Internet:

- Permite o desenvolvimento de aplicações que podem ser estendidas a toda a cadeia de valor integrando suas atividades (figura 3.5);

- É uma tecnologia flexível que uma vez adaptada à estratégia da empresa, pode ser uma poderosa fonte de vantagem competitiva

- Possui potencial para suportar um posicionamento estratégico diferenciado (PORTER, 1996), uma vez que as empresas podem ser criativas na forma de conectarem suas atividades criando arranjos inovadores e difíceis de serem copiados.

No entanto, de acordo com a visão de Porter (2001), os fundamentos da competição permanecem inalterados. $O$ autor alerta que a Internet não representa uma ruptura, mas sim um complemento à estratégia.

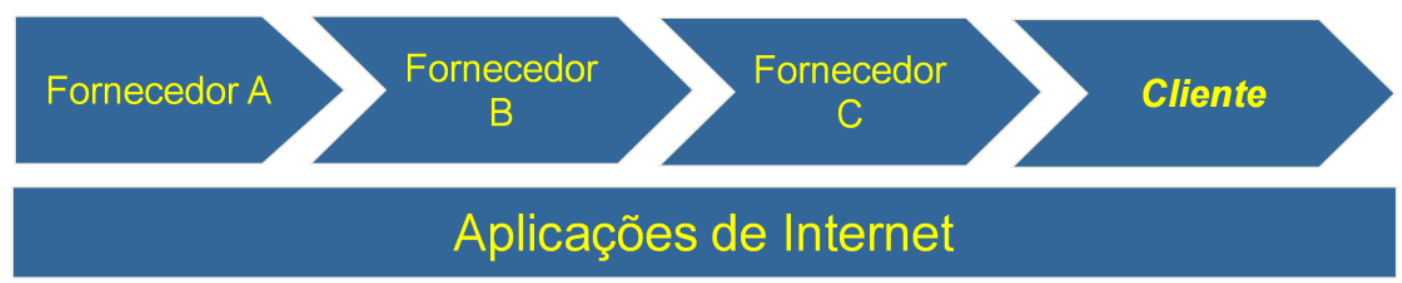

Figura 3.5: Integração do sistema de valor gerada pela Internet

\subsubsection{As implicações da virtualidade nos negócios}

Através do espaço virtual explorado por Anghern (1997) no modelo Information, Communication, Distribution and Transactional (ICDT), pode-se compreender melhor as implicações da virtualidade nos negócios e a importância da Internet 
na viabilização dos mercados virtuais. Segundo o modelo, há quatro formas de da Internet estender o espaço tradicional do mercado (figura 3.6):

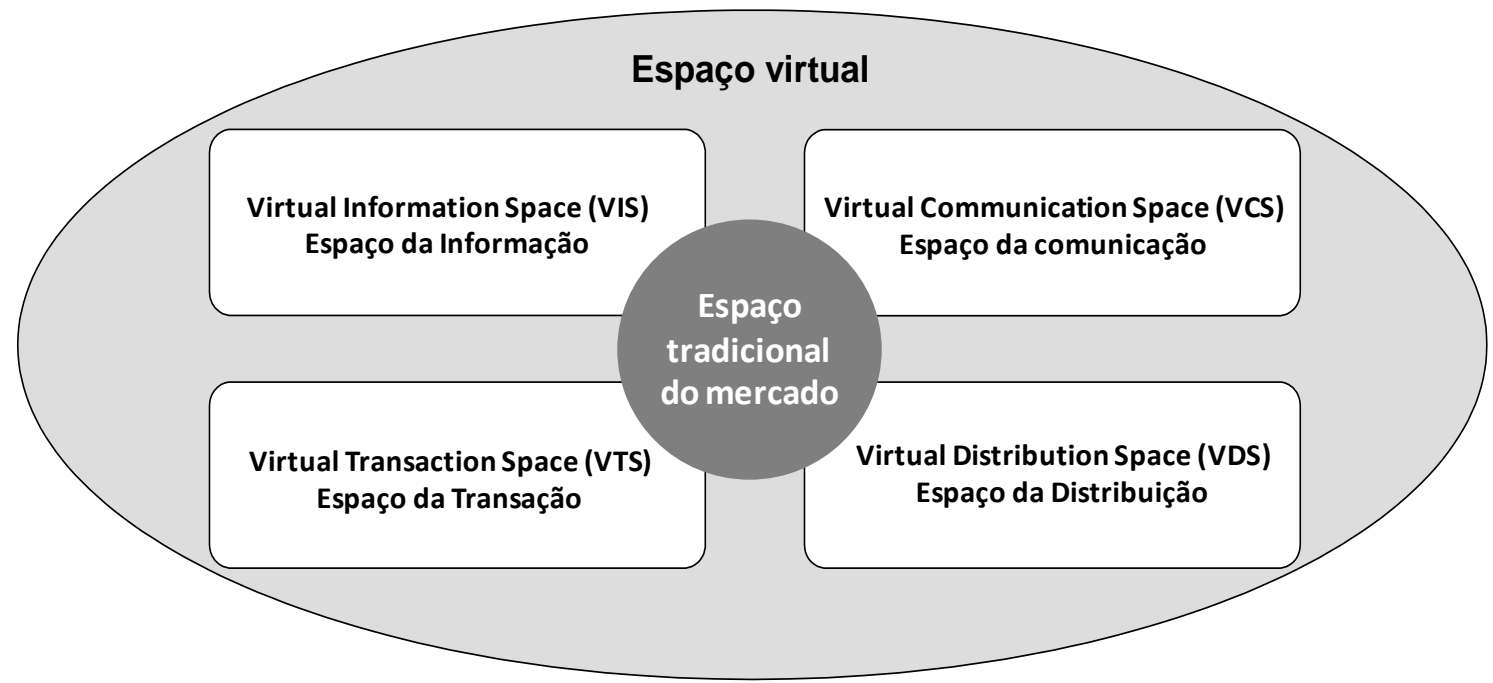

Figura 3.6 - O espaço virtual, segundo o modelo ICDT (adaptado de Anghern, 1997)

- $\quad$ Espaço virtual da informação (VIS) - disponibiliza as informações da empresa a todos os agentes do mercado (clientes, fornecedores, prospects) que possuam acesso à Internet. Através do VIS, o mercado potencial da empresa aumenta pois as barreiras geográficas são abolidas, o usuário pode navegar no site a partir de qualquer lugar do mundo, 24 horas por dia. Porém, a concorrência é ampliada, uma vez que o cliente possui acesso a mais empresas e pode comparar ofertas online.

- $\quad$ Espaço virtual da comunicação (VCS) - aumenta o poder de interação dos agentes com a empresa, o usuário pode interagir através de correio eletrônico, fóruns, chats, plantões de dúvidas. Essa interação aumenta o poder dos usuários uma vez que os mesmos podem: solicitar a empresa produtos com configurações específicas, montar fóruns de discussão sobre a empresa, e num limite extremo até tornar os usuários "co-desenvolvedores" do produto através de processos interativos como acontece com versões beta de softwares (Prahalad \& Ramaswamy 2000).

- Espaço virtual da distribuição (VDS) - conecta consumidores e empresas eliminando intermediários. Como poderá ser notado nos estudos de caso, essa eliminação de intermediários é mais comum em mercados de serviços. 
- $\quad$ Espaço virtual das transações (VTS) - possibilita operações de ecommerce entre empresa e consumidores "business to consumer" (B2C), entre empresas "business to business" (B2B), entre consumidores "consumer to consumer" (C2C) como ocorre nos portais de leilão. O VTS gera ganhos para a empresa através do processamento automático de pedidos, pagamento facilitado e alcance de um universo maior de consumidores.

Essa virtualidade pode implicar em mudanças em toda a organização melhorando o conhecimento, a estrutura organizacional ou relacionamento com o consumidor (VENKATRAMAN \& HENDERSON, 1998) ou dando suporte ao processo de criação de novos produtos e serviços (MATTOS \& LAURINDO, 2008).

\subsubsection{A cadeia de valor virtual}

Chandrashekar \& Schary (1999) notaram que a evolução das telecomunicações e dos sistemas de informação (figura 3.7) possibilitou um novo conceito de integração, as cadeias de valor virtuais (figura 3.8). Essas cadeias possuem como características:

- A liberdade de mudar a forma e as parcerias de forma a atingir flexibilidade. Essas cadeias funcionarão como redes latentes que operam sob demanda.

- A habilidade de seus gestores em organizar e administrar redes flexíveis que se torna vantagem crucial na competição.

- Padrões comuns entre as indústrias que operam. Isto inclui: padrões técnicos de comunicação, facilitados em grande parte pela Internet; padrões de sistemas de informação comuns como codificação de materiais e agentes inteligentes (ex.: pedido de compra automático) que podem ser viabilizados por arquiteturas orientadas a serviços (SOA). 


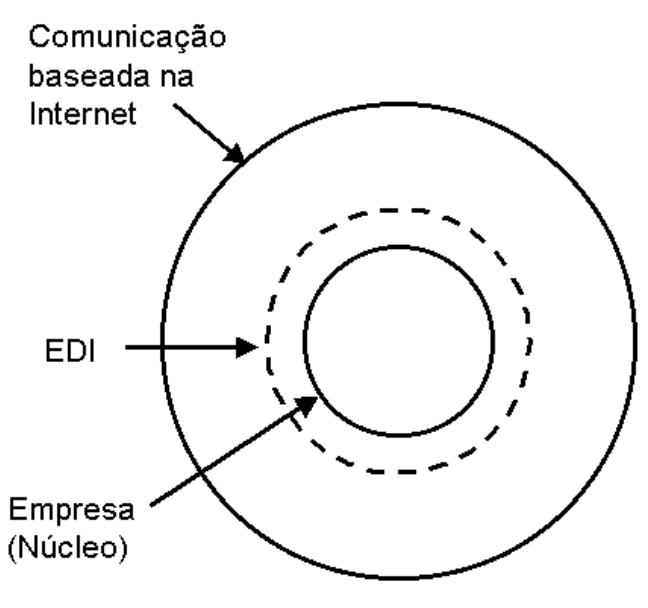

Telecomunicação de dados

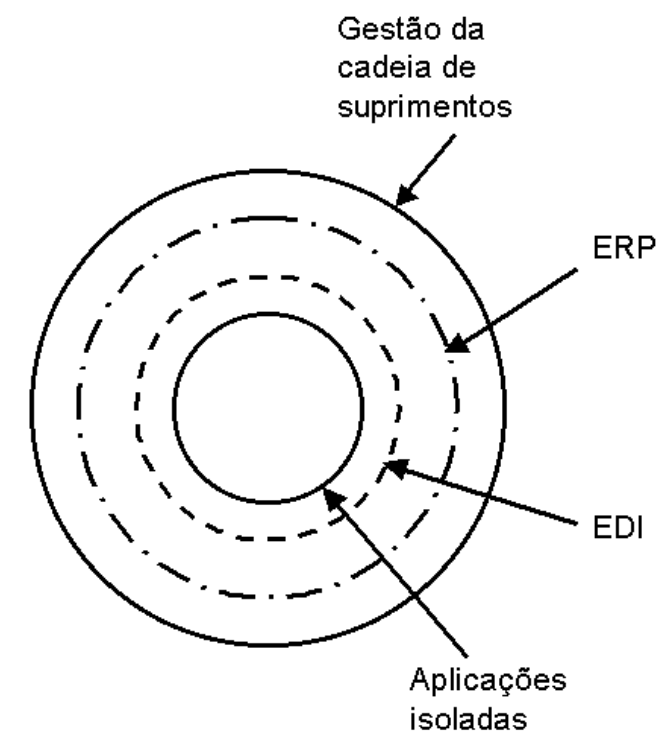

Sistemas de gestão computacionais

Figura 3.7: Evolução da telecomunicação e sistemas de gestão computacionais (adaptado de Chandrashekar \& Schary, 1999)

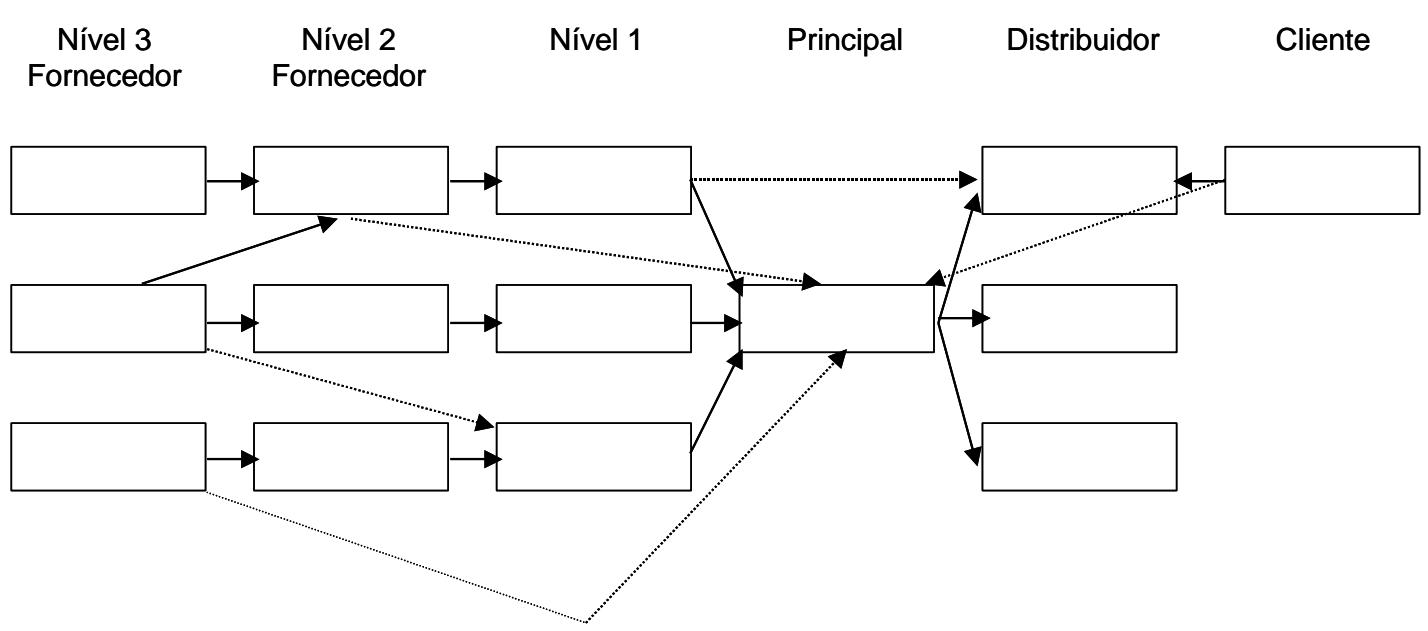

Tipos de relacionamentos

Normais

- Potenciais ou esporádicas

Figura 3.8: Evolução da telecomunicação e sistemas de gestão computacionais (adaptado de Chandrashekar \& Schary, 1999)

Ao conceituarem as cadeias de valor virtuais, Rayport e Sviokla (1995) foram além ao tratar essas cadeias como fontes de valor e não como elementos de suporte ao processo de adição de valor. Segundo os autores, as empresas possuem dois domínios para competirem: o marketplace e o marketspace. 0 
marketplace seria a parte física, as lojas, os pontos de atendimento, as interações presenciais com o consumidor, na indústria bancária, equivaleria as operações realizada na rede de agências. O marketspace representa o mundo virtual, a forma de oferecer os produtos e serviços eletronicamente, para os bancos seria o equivalente ao Internet banking. As empresas podem se tornar mais competitivas ao oferecerem diferenciais no marketspace, como por exemplo, fez a FEDEX ao disponibilizar o tracking de suas entregas pela Internet. Durante algum tempo, ela obteve vantagem competitiva frente a seus concorrentes, através de uma maior transparência de seus processos físicos espelhados no ambiente virtual. Essa mesma competitividade pode ser expandida para economias nacionais, através da Companhia de Internet Chinesa, o governo chinês fornece uma plataforma que facilita o comércio exterior para empresas de todos os portes.

\subsubsection{As redes de valor}

Bovet e Martha (2001) verificam que o próprio desenho da cadeia de valor não representa mais a forma das empresas se conectarem. Eles observam que redes de valor (figura 3.9) são mais apropriadas às conexões digitais, flexíveis e temporárias estabelecidas pelas empresas atualmente. Essas redes apresentam as seguintes características:

- Alinhamento com o cliente - clientes de segmentos distintos recebem soluções personalizadas.

- Cooperação e sistematização - a Internet cria um relacionamento com os parceiros e possibilita a administração colaborativa.

- Rapidez no fluxo de produtos e serviços - facilitando entregas no prazo e diminuição nos estoques no caso de produtos.

- Digital - plataforma para e-business e possibilidade de fluxo de fluxo de informações eficiente.

- Ágil e flexível - receptividade quanto às mudanças de necessidades e lançamentos de novos serviços. 
Cadeia de Valor

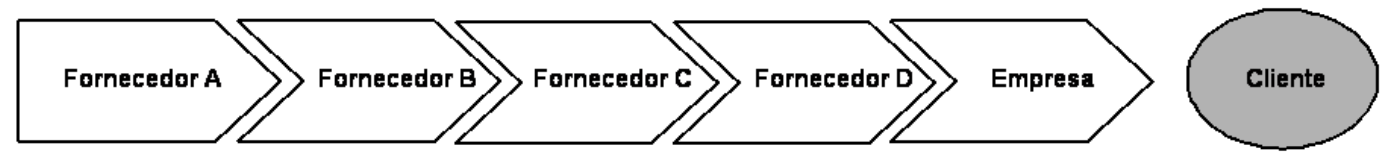

Rede de Valor (1)

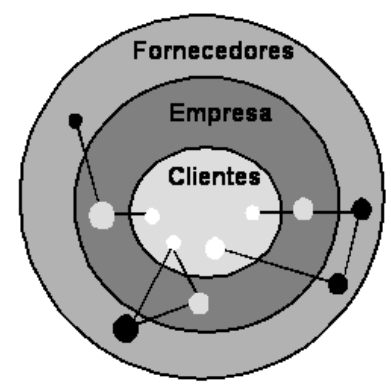

\begin{tabular}{|l|l|}
\hline \multicolumn{1}{|c|}{$\begin{array}{c}\text { Cadeia de Valor } \\
\text { Tradicional }\end{array}$} & \multicolumn{1}{c|}{ Rede de Valor } \\
\hline $\begin{array}{l}\text { Único formato para qualquer } \\
\text { finalidade }\end{array}$ & Alinhada com o cliente \\
\hline Rigida, inflexivel & Agil, flexivel \\
\hline Independente e seqüencial & Colaborativa e sistemática \\
\hline Analógica & Digital \\
\hline
\end{tabular}

Nota: 1 - Tamanho das esfera seria o tamanho de cada agente através de um indicador, por exemplo, faturamento

Figura 3.9: Cadeia de valor versus rede de valor (adaptado de Bovet \& Martha 2001)

\subsubsection{Modelos de criação de valor para o e-business}

Amit \& Zott (2001) realizaram uma extensa pesquisa com mais de 50 empresas distribuídas globalmente de emergiram dois insights teóricos: (i) existem quatro fontes de criação de valor presentes no e-business: eficiência, complementaridades, fidelização (lock-in) e inovação (figura 3.10); (ii) o modelo de negócios é o principal local para criação do valor em e-business, por conseqüência é a unidade de análise mais apropriada, pois transpõe a empresa e suas fronteiras.

Os autores argumentam que a presença dos quatro drivers e as ligações entre eles, que estão ancoradas no empreendedorismo e na teoria de gestão estratégica impulsionam a criação de valor em e-business (figura 3.10).

Os quatro pilares para criação de valor em e-business

A eficiência é um dos drivers primários para criação de valor em e-business. Quanto maiores os ganhos de eficiência possibilitados por um negócio de ebusiness, menores os custos e consequentemente o negócio torna-se mais valioso.Ganhos de eficiência podem ocorrer de diversas formas: reduzindo a assimetria de informações entre fornecedor e comprador através do fornecimento de informação abrangente e atualizada; reduzindo custos de distribuição; melhorando a gestão de estoques; permitindo que o consumidor 
individual beneficie-se das economias de escala através da demanda agregada e compra em massa entre outras.

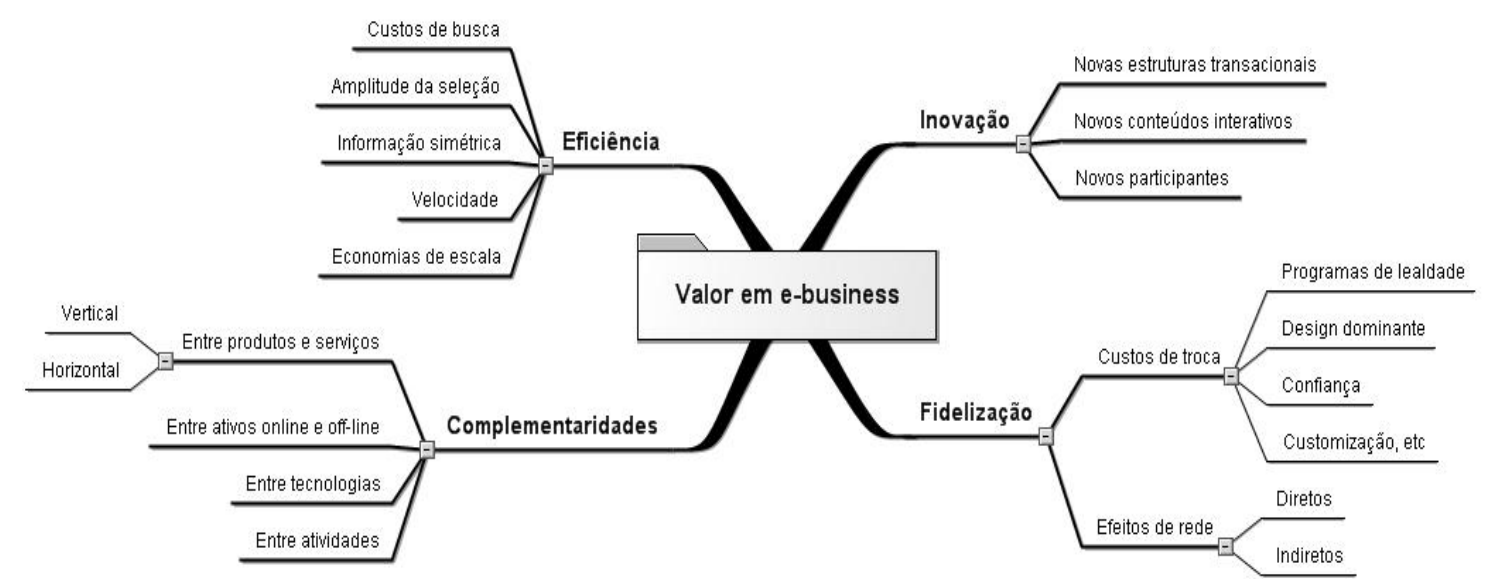

Figura 3.10: Fontes de criação de valor na Internet (adaptado de Amit \& Zott, 2001)

Complementaridades estão presentes sempre que uma série de bens em conjunto é mais valiosa que a soma de cada bem separadamente. A análise de dados sugere que o e-business impulsione o potencial para criação de valor pela oferta de conjuntos de produtos e serviços complementares para os consumidores. As complementaridades podem ser verticais, como, por exemplo, uma loja que oferece serviços pós-venda como garantia ou instalação, ou podem ser horizontais, como um one-stop shopping, ou a venda de um palm mais a memória, o estojo e o teclado.

Complementaridade e eficiência andam juntas. Quando vários parceiros compartilham um site para vender seus produtos e serviços, há uma redução nos custos que torna a operação online mais eficiente. A recíproca também é verdadeira, quando uma loja vende o seguro junto com 0 produto, 0 consumidor beneficia-se da complementaridade tornando sua compra mais rápida e eficiente.

Através da fidelização, o potencial de criação de valor de um e-business é impulsionado pela parcela de consumidores que estão motivados a repetir as transações e pelo total de parceiros estratégicos que possuem incentivos para manter e melhorar suas associações, que podem resultar em mais desejo de compra e menores custos de oportunidades para as empresas. Um exemplo dessa fidelização é a familiaridade com a interface do site requer aprendizado 
do consumidor; uma vez iniciado, esse aprendizado inibe os consumidores a trocarem de site no qual o aprendizado deve começar de novo. As comunidades virtuais podem gerar efeitos de rede que mantêm os usuários conectados. Esses efeitos podem ser diretos, como ocorre, por exemplo no Facebook, quanto mais pessoas estiverem conectadas através desse site melhor; ou indiretos, como no caso de um site de leilão virtual, em que os usuários podem não obter vantagens imediatas com o maior número de visitantes, mas que no futuro serão beneficiados pelo maior número de pessoas oferecendo produtos.

Eficiência e complementaridades podem favorecer a fidelização dos usuários. A eficiência da interface - execução fácil das atividades no site - e das operações offline que apoiam a operação online, como a logística, é fator determinante para que o cliente volte ao site. Serviços complementares e diferenciados são mais uma arma para manter o consumidor fiel ao site.

A inovação cumpre um importante papel na criação de valor (SCHUMPETER, 1934, apud AMIT \& ZOTT, 2001). As fontes tradicionais de inovação são a introdução de novos produtos e serviços, novos métodos de produção, distribuição e marketing ou a exploração de novos mercados. A Internet agregou uma nova forma de inovar: a mudança na forma de estruturar uma transação. Por exemplo, o eBay foi a primeira empresa a introduzir leilões entre consumidores em larga escala. Nessa arquitetura, até produtos de baixo valor podem ser comercializados entre consumidores individuais.

As empresas podem criar valor conectando agentes outrora desconectados e eliminando ineficiências nos processos de compra e venda graças aos novos métodos de transacionar.

Inovação e fidelização estão ligadas de forma relevante. Ser o primeiro é uma vantagem em termos de marca e também por acostumar o usuário com a interface, o que o levaria a retornar ao site. A inovação também está ligada às complementaridades das quais a principal inovação de alguns e-business residem na complementaridade de seus elementos. Por exemplo, um varejista de computadores americano, a Cyberian Outpost, possui um banco de dados atualizado de 170 mil itens. Esse banco armazena informações de produtos complementares das empresas parceiras e cada um dos produtos é 
apresentado com possíveis soluções complementares assim como opções de produtos substitutos.

Há também uma importante relação entre inovação e eficiência. Certos ganhos de eficiência estão relacionados a inovações disponibilizadas pela Internet. Um mercado eletrônico pode reduzir a assimetria de informações tornando fácil a comparação de preços entre fornecedores; pode também minimizar problemas de entrega ao conceder notas aos fornecedores cujas ações geram ganhos de eficiência quando aplicadas a mercados desconectados.

O constructo do modelo de negócios

Baseado na análise de criação de valor no e-business, Amit \& Zott (2001) propõem o modelo de negócios como uma unidade de análise. De acordo com a definição:

"O modelo de negócios representa o conteúdo, a estrutura e a governança das transações desenhadas com a finalidade de criar valor através da exploração de oportunidades de negócio"

(AMIT \& ZOTT, 2001, p. 511)

O conteúdo representa os bens ou informações negociados e os recursos e capacidades necessárias para negociar. A estrutura são os parceiros que participam da intermediação e as formas como as parcerias estão ligadas. Por fim, a governança refere-se à maneira como os fluxos de informação, recursos e bens são controlados pelos parceiros. Na Tabela 3.2, são apresentados exemplos de criação de valor a partir de cada elemento do modelo de negócios (Amit \& Zott, 2001).

\subsubsection{A co-criação de valor}

Um dos efeitos das redes virtuais é a ampliação do escopo de fornecedores Ao colocar os clientes e consumidores no centro da rede de valor, Bovet \& Martha (2001) ressaltam o papel de protagonista que eles possuem. Cada vez mais as empresas devem estar sensíveis às experiências desse consumidor na Internet, pois o relacionamento com ele é dinâmico e interativo. Suas opiniões sensibilizam a de outros consumidores e ditam as ofertas de produtos e serviços das empresas. Segundo Prahalad e Ramaswamy $(2000,2004)$ as empresas devem ser pró-ativas nesse relacionamento e procurar identificar 
competências e hábitos de seus consumidores para nortearem suas ofertas. Empresas líderes do mercado de tecnologia como Apple, Amazon, Facebook, GroupOn e Zynga (especializada em games online) aproveitam-se dessas competências e, até mesmo de vulnerabilidades dos usuários, para construir uma forma de relacionamento onde o consumidor enxerga seus produtos e serviços como essenciais para seu dia-a-dia (ARIELY, 2011).

Tabela 3.2: Exemplos de criação de valor a partir do modelo de negócios (adaptado de Amit \& Zott, 2001)

\begin{tabular}{|c|c|c|c|c|}
\hline & Eficiência & Complentaridades & Fidelização & Inovação \\
\hline $\begin{array}{ll}\text { Estrutura } & \text { do } \\
\text { modelo } & \text { de } \\
\text { negócios } & \end{array}$ & $\begin{array}{l}\text { Mecanismo de troca } \\
\text { Velocidade de } \\
\text { transação } \\
\text { Custos } \\
\text { negociação } \\
\text { Custos } \\
\text { marketing, vendas e } \\
\text { processos } \\
\text { internacionais } \\
\text { Acesso a um grande } \\
\text { número de produtos, } \\
\text { serviços de estoque } \\
\text { Custos de empresas } \\
\text { das } \\
\text { participantes } \\
\text { Simplicidade } \\
\text { transação de } \\
\text { Demanda agregada } \\
\text { Geração } \\
\text { suprimentos de } \\
\text { Escalabilidade de } \\
\text { volume de transações }\end{array}$ & $\begin{array}{l}\text { Venda cruzada } \\
\text { Atividades dos } \\
\text { participantes } \\
\text { Combinação de } \\
\begin{array}{l}\text { transações online e } \\
\text { offline }\end{array}\end{array}$ & 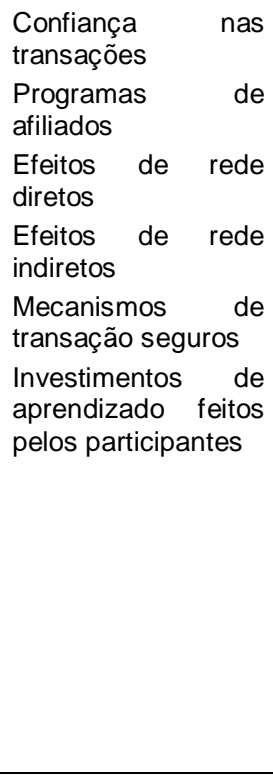 & $\begin{array}{l}\text { Novos participantes } \\
\text { Nível sem } \\
\text { precedentes de } \\
\text { participantes e/ou } \\
\text { bens negociados } \\
\text { Novas ligações entre } \\
\text { os participantes } \\
\text { Riqueza sem } \\
\text { precedentes de } \\
\text { ligações (qualidade e } \\
\text { profundidade) } \\
\text { Patentes aplicadas } \\
\text { (ou acordos de } \\
\text { confidencialidade) em } \\
\text { modelos de negócios } \\
\text { Primeiro a introduzir } \\
\text { modelo de negócios }\end{array}$ \\
\hline $\begin{array}{l}\text { Conteúdo } \\
\text { modelo } \\
\text { negócios }\end{array}$ & 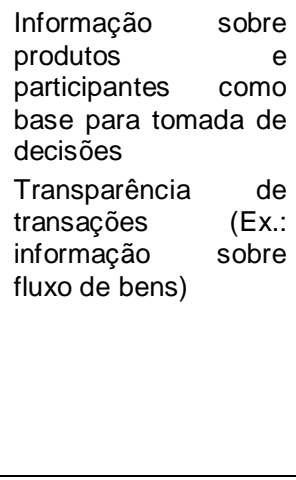 & 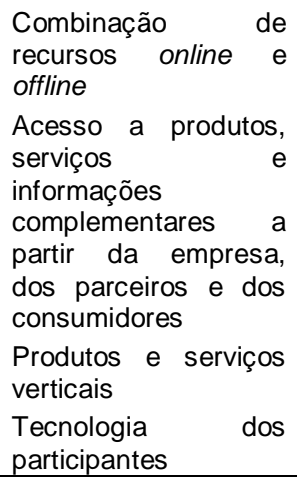 & $\begin{array}{l}\text { Aumento da } \\
\text { confiança entre os } \\
\text { parceiros } \\
\text { Participantes } \\
\text { desenvolvem ativos } \\
\text { especializados } \\
\text { Design dominante } \\
\text { Ofertas } \\
\text { funcionalidades } \\
\text { customizados e ou } \\
\text { personalizados }\end{array}$ & $\begin{array}{ll}\text { Novos } & \text { (ou } \\
\text { combinações de) } \\
\text { produtos, serviços e } \\
\text { informações }\end{array}$ \\
\hline $\begin{array}{l}\text { Governança } \\
\text { dos modelos } \\
\text { de negócios }\end{array}$ & & 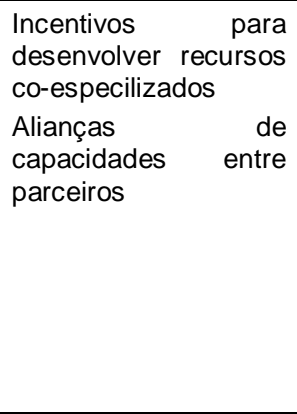 & 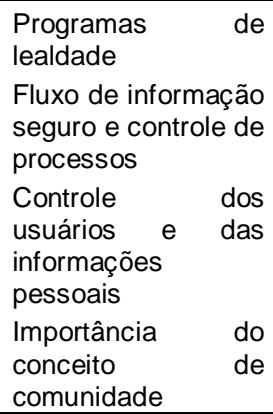 & $\begin{array}{l}\text { Novos incentivos } \\
\text { (Ex.: cliente pode } \\
\text { criar conteúdo) }\end{array}$ \\
\hline
\end{tabular}


Um exemplo da co-criação e produtos é do carro Fiat Mio através do site http://www.fiatmio.cc. Nesse site, os consumidores deram suas opiniões, foram mais de 10 mil ideias e 17 mil comentários enviados. A partir dessas ideias, a Fiat desenvolveu um carro conceito (figura 3.11) que foi lançado no salão do automóvel de 2010 (FIAT, 2011).

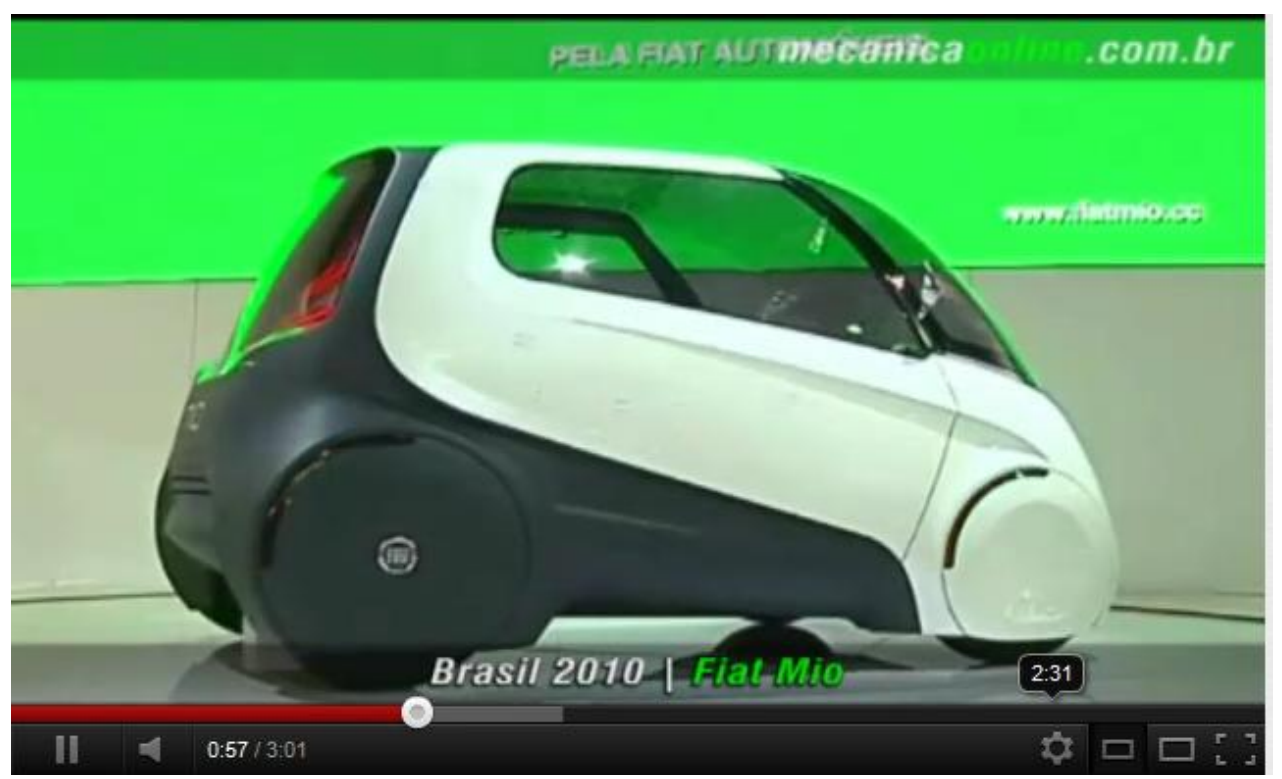

Figura 3.11: Modelo Fiat Mio apresentado no salão do automóvel de 2010 (YOUTUBE, 2011)

O customer knowledge management (CKM) (GIBBERT et al., 2002) potencializa a co-criação ao alterar o papel dos consumidores no desenvolvimento de produtos e serviços. Num primeiro momento, as empresas se baseavam nos hábitos do consumidor para se apropriar de suas competências para pesquisa e desenvolvimento de produtos Prahalad \& Ramaswamy (2000). No entanto, ao gerenciar o conhecimento gerado pelos próprios consumidores nas redes sociais, a empresa pode co-criar os produtos junto com eles, criando valor através de experiências únicas e personalizadas dos consumidores (PRAHALAD \& RAMASWAMY, 2004; PRAHALAD \& KRISHNAN, 2008). Segundo Tapscott \& Williams (2007), essa integração entre os agentes subsidia o desenvolvimento de uma nova economia.

A figura 3.12 demonstra essa nova arquitetura de criação para indústria de mídia, onde criadores, remixadores, entusiastas e fãs casuais retroalimentam a produção de conteúdo, gerando novas produções (remixes) e contextualizando a produção existente através de metadados sobre a própria produção: data de 
produção, título, resumo da obra; e metadados sobre o uso: opiniões sobre a obra, quais foram os diferentes entendimentos dela e sugestões de aplicação.

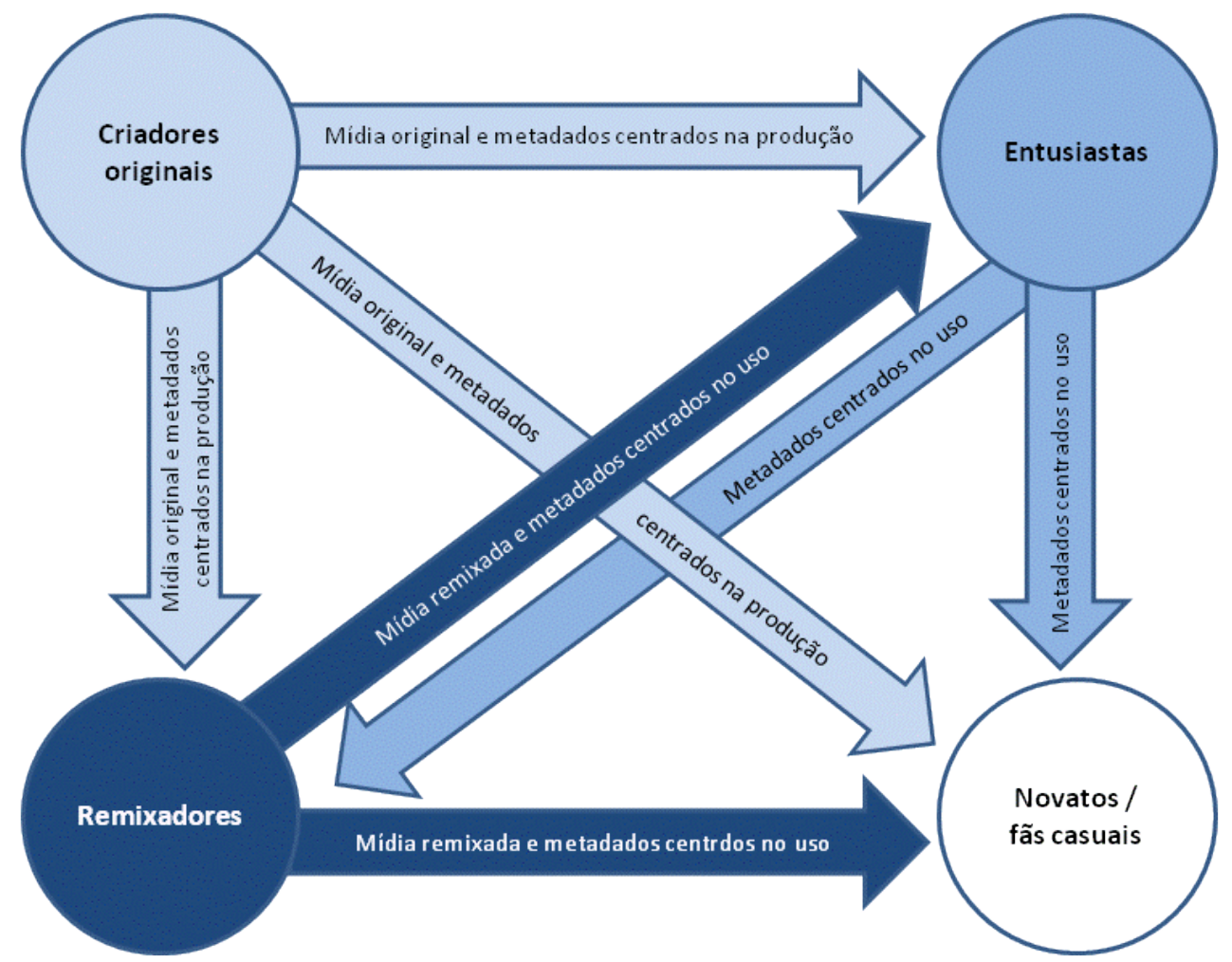

Figura 3.12: Arquitetura de criação (ANDERSON, 2006; SHAMMA et al., 2007)

\subsubsection{A cauda longa}

Segundo Anderson (2006) as transformações tecnológicas provocaram uma transformação da curva da demanda:

"Nossa cultura e nossa economia estão cada vez mais se distanciando do foco em alguns hits relativamente pouco numerosos (produtos e mercados de tendência dominante), no topo da curva da demanda, e avançando em direção a uma grande quantidade de nichos na parte inferior da curva ou na cauda da curva de demanda." (ANDERSON, 2006, p.50)

Antes do advento dessa mudança, a curva de demanda poderia ser explicada pelo princípio do economista italiano Vilfredo Pareto, onde pelo menos $80 \%$ dos efeitos advém de $20 \%$ das causas. Por exemplo, ao se observar o histórico de vendas de uma livraria, $20 \%$ dos títulos gerariam mais de $80 \%$ do faturamento. 
Anderson (2006) demonstra que o princípio de Pareto não se aplica a curva da demanda de diversas indústrias como a fonográfica, a editorial e a cinematográfica. O autor cita o exemplo da Netflix, locadora de vídeos online, quem no ano 2000 , tinha mais de $70 \%$ das locações relacionadas aos 500 filmes mais assistidos. Em 2005, os 500 vídeos mais assistidos representavam menos de $50 \%$ da demanda, sendo que $15 \%$ do faturamento advém de produtos que estão além da posição 3.000 no ranking, produtos esse que não são oferecidos por locadoras de tijolo e cimento, pois não se encontram em estoque (figura 3.13).

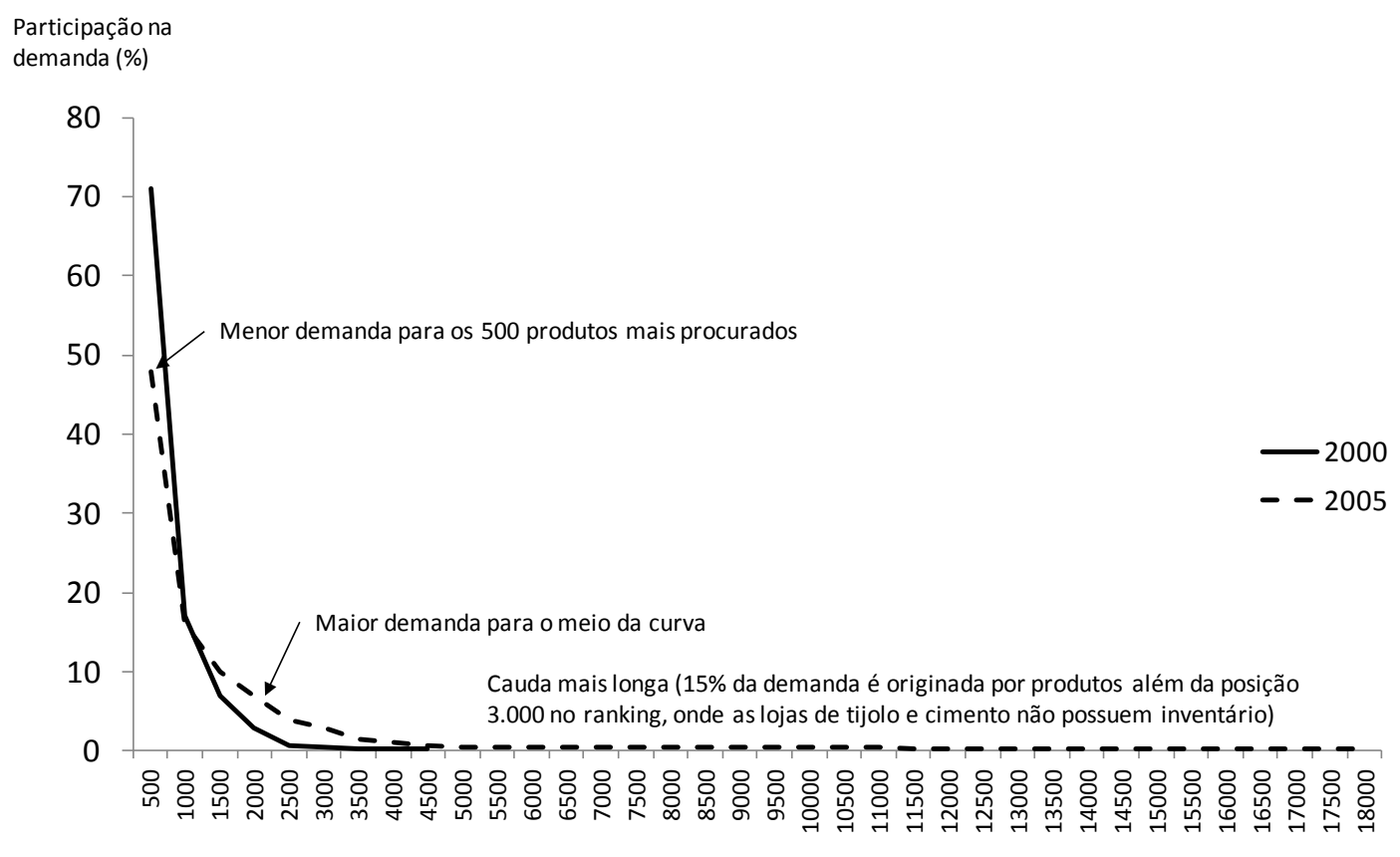

Posição dos produtos no ranking

Figura 3.13: Mudança na demanda da Netflix entre 2000 e 2005 (Anderson, 2009)

Segundo Anderson (2006), a cauda longa foi impulsionada por três mudanças na economia:

- A democratização da produção possibilitada por novas ferramentas como blogs, software para edição de música e vídeos e câmeras digitais, permite que pequenas empresas e pessoas físicas tornem-se produtores.

- A democratização da distribuição, ao eliminar barreiras físicas, empresas como Amazon, Mercado Livre, iTunes e Netflix facilitam a distribuição de produtos com custos de distribuição tendendo a zero. 
- Ligação entre oferta e da demanda. Sites como Google, redes sociais e recomendações de produtos ("Quem comprou o produto $A$, também comprou B") estimulam a demanda e faz com que o consumidor conheça novas possibilidades de atender às suas necessidades.

Ao possibilitar que cada vez mais produtores encontrem nichos de mercado para seus produtos específicos, a cauda longa favorece o surgimento de novos posicionamentos estratégicos.

Enquanto as empresas que atendem a cabeça da demanda competem de acordo com as regras de indústrias estabelecidas (Porter, 1979), denominadas de oceano vermelho por Kim (2005). Algumas empresas montam suas estratégias para atuarem no oceano azul, onde a competição torna-se irrelevante.

Segundo Kim (2005), os fatores que caracterizam as empresas que competem no oceano vermelho são:

- Competir em mercados existentes

- Enfrentar a competição

- Aproveitar a demanda existente

- Fazer o trade-off entre custo e valor

- Alinhar todo o sistema de valor da empresa com sua opção estratégica de diferenciação ou liderança em custo baixo

Enquanto os itens que caracterizam a competição no oceano azul são:

- Criar espaços incontestáveis no mercado

- Tornar a competição irrelevante

- Criar e capturar novas demandas

- Quebrar o trade-off entre custo e valor

- Alinhar todo o sistema de valor da empresa na busca de diferenciação e baixo custo 


\section{Digital Analytics}

\subsection{Conceituação de Digital Analytics}

Segundo Cutroni (2012) Digital Analytics (DA) é a medição, coleta, análise e elaboração de relatórios de dados digitais para os propósitos de entendimento e otimização da performance em negócios. Esse conceito é uma evolução do conceito de Web Analytics que era mais restrito à otimização do site e das campanhas digitais (WAA, 2008; PETERSON, 2004). O conceito de DA incorpora dados de múltiplas fontes como aplicativos móveis e tecnologia embarcada e estende os resultados da análise para toda a organização visando à melhoria da eficiência e eficácia do negócio.

A evolução desse conceito é ilustrada pela mudança de nome da Web Analytics Association para Digital Analytics Association ocorrida em março de 2012, segundo Jim Stern, conselheiro da Digital Analytics Association: "nosso novo nome é uma melhor reflexão de toda a gama do campo de análise de dados que nós nos esforçamos para apoiar" (DIGITAL ANALYTICS ASSOCIATION, 2012). O termo Web Analytics ainda é encontrado com bastante frequência na literatura, porém nesse estudo, será adotado o conceito de Digital Analytics (DA) devido à evolução da terminologia. Ainda que os autores tenham usado o termo Web Analytics, será utilizado o termo mais recente reconhecido pela Digital Analytics Association.

O conceito de DA está relacionado à presença online da empresa. Essa presença é constituída da presença ativa, que são as ações que visam atrair o internauta para o site como campanhas online, e-mail marketing e links patrocinados. O próprio site da empresa, ou seu conjunto de domínios na Internet, é considerado como a presença receptiva, no sentido que recebem o usuário. Paralelamente à presença online da empresa, existem as mídias sociais que são as redes sociais como Facebook e Orkut, blogs e fóruns onde os consumidores podem opinar e comentar as iniciativas da empresa.

Existem algumas lacunas que geram diversos problemas que dificultam o aproveitamento do potencial de DA. Uma issue crítica é a ausência de alinhamento com a estratégia de negócios (KAUSHIK, 2009). Essa dificuldade 
adicionada ao caráter técnico dos relatórios de tráfego no site, faz com que o consumidor não ser considerado o centro das análises (KAUSHIK, 2009; ARUN et al, 2006), tornando os relatórios de DA cheios de dados, mas com pouca relevância para a tomada de decisão corporativa (STERN, 2010), (ARUN et al, 2006).

A falta de dados qualitativos também agrega dificuldades para tomar decisões que exijam um conhecimento maior sobre o consumidor (BUGHIN et al, 2008; KAUSHIK, 2009). As métricas de DA ajudam a identificar problemas como, por exemplo, a evasão do usuário logo na primeira página visualizada do site. Mas é difícil entender o motivo dessa evasão sem entrevistar o usuário.

Uma outra barreira é a falta de integração entre dados de ações online e offline para melhorar os resultados de empreendimentos corporativos como campanhas e novos produtos (BUGHIN et al, 2008; SHANKAR \& YADAV, 2010).

Devido a essas limitações, Kaushik (2009) propôs uma definição que fosse ampla o suficiente para abranger o potencial do conceito de DA, ele definiu DA como a análise dos dados qualitativos e quantitativos de um determinado site e dos seus competidores, para direcionar uma melhoria contínua da experiência online dos consumidores, e potenciais consumidores, a fim de produzir os resultados desejados pela empresa (online e offline). A definição de Kaushik (2009) será utilizada para estudar se identificar as premissas de capacidade analítica e gestão do negócio.

Além da definição do conceito de DA, uma outra dificuldade é a própria delimitação do campo de abragência de DA, uma vez que uma série de conceitos correlatos possuem sobreposições com DA. Os principais termos correlatos identificados na literatura são web mining, web semantics e web personalization.

O web mining é a produção de análises avançadas sobre o comportamento do usuário como segmentações baseadas em softwares que rastreiam os hábitos de navegação (LARSEN et al, 2002; SEGALL \& ZHANG, 2009; ZHANG \& SEGALL, 2010). Para finalidade dessa pesquisa, o web mining foi entendido como uma poderosa ferramenta que impulsiona DA, porém não está diretamente relacionado à eficácia e sim a eficiência das análises. 
Já a web semantics complementa as tecnologias conhecidas como web 2.0 centradas no usuário (redes sociais, blogs e wikis) através de uma representação do conhecimento baseada num tipo de ontologia, essa estrutura é extraída do conteúdo produzido pelo usuário através de técnicas avançadas como data mining, análise de redes sociais e redes neurais (BERENDT et al, 2010; DIX et al, 2010; ROWE \& CIRAVEGNA, 2010). Por seu aspecto complementar à web 2.0 também é conhecida como web 3.0 (LAFUENTE, 2011). As análises de web semantics parecem agregar ao conceito de DA, principalmente quando relacionadas às análises de mídias sociais e dos termos digitados nos mecanismos de busca, por esse motivo há uma sobreposição que será explorada nas variáveis de capacidade analítica.

A web personalization é processo de customização do site de acordo com a necessidade do usuário, tirando vantagem do conhecimento adquirido da análise do comportamento de navegação (EIRINAKI \& VAZIRGIANNIS, 2003). Esse conceito está relacionado à aplicação dos conhecimentos de DA, com execução em tempo real. Sendo entendido mais como uma automatização do processo de DA do que um paradigma conceitual.

\subsection{Métricas de DA}

\subsubsection{Métricas para presença receptiva}

A Digital Analytics Association (WAA, 2008) elaborou um glossário com os termos mais comuns relacionados à DA, esses termos abrangem: elementos básicos (usados em diversas análises), termos de caracterização da visita ao site, termos de caracterização do visitante, termos de engajamento, termos de conversão e termos correlatos.

Os elementos básicos são centrais a qualquer análise de DA, páginas, visualização de páginas, visitas, visitantes únicos e eventos. Vale destacar a diferença entre a visita que é uma ação e o visitante, que é o realizador da ação. As ferramentas de DA, normalmente relacionam o visitante a um cookie, que é um arquivo texto que fica armazenado na máquina do usuário todas as vezes que ele visita o site, esse arquivo texto possui um código de identificação o visitante. Se um visitante acessar o site mais de uma vez, ele será contado como um visitante único, pois a ferramenta verifica que os acessos partem de 
um mesmo cookie e cada acesso ao site será contabilizado como uma visita diferente.

Portanto o visitante gera diversas visitas. Durante uma visita, podem ocorrer $\mathrm{n}$ visualizações de páginas. E numa visualização de página, o usuário realiza diversos eventos conforme apresentado na figura 4.1.

Os eventos ganham especial devido ao nível de interação dos aplicativos mobile e também de mídias sociais. Por exemplo, ao ver o perfil no Facebook, o usuário realiza uma diversidade de eventos em apenas uma visualização de página, como por exemplo, curtir um comentário. Por isso, esses eventos também devem ser monitorados, pois são parte integrante da experiência do usuário (CUTRONI, 2010).

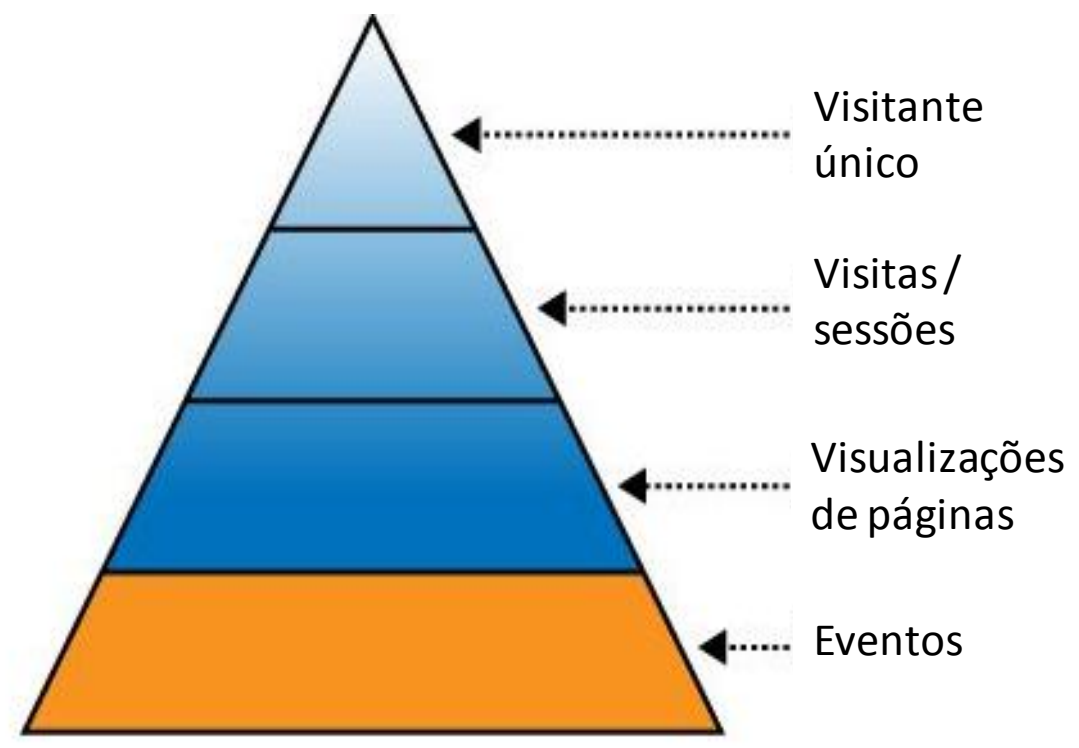

Figura 4.1: Camadas da hierarquia de dados de DA (CUTRONI, 2010)

A Digital Analytics Association (WAA, 2008) selecionou uma série de termos que caracterizam o visitante:

- Novo visitante

- Visitante que retorna (independente do período do relatório)

- Visitante repetido (que retorna durante o período do relatório)

- Visitas por visitante

- Recência (tempo desde que usuário visitou o site pela última vez)

- Frequência (número de visitas num período)

As visitas também são relevantes nas análises e podem ser mensuradas ou contextualizadas de acordo com os seguintes dados: 
- Página de entrada

- Página de entrada relacionada à campanha online (landing page)

- Páginas de saída

- Duração da visita

- Origem do tráfego para página

- Origem do tráfego para visita

- Clicks em links (clique through)

- Taxa de cliques vs visualições do link (clique through)

O engajamento representa o quanto o usuário está interagindo com a presença online da empresa e pode ser contextualizado com os seguintes dados:

- Taxa de saída (Número de saídas através da página vs visualizações da página)

- Visitas onde usuário viu apenas uma página (bounce)

- Taxa de bounces sobre total de visitas (bounce rate)

- Páginas vistas por visita

A conversão por sua vez, ocupa papel central na análise do negócio, pois mede quanto o site está contribuindo para gerar resultados para a empresa, de maneira simplificada, ela pode ser registrada através da:

- Conversão (Ações desejadas como vendas e atendimentos realizadas no site)

- Taxa de conversão (Conversões versus total de visitas)

Há outros termos mais técnicos, que são correlatos à DA. Merecem destaque:

- Hits (acessos ao servidor)

- Impressões (Número de vezes Impressões foi entregue ao usuário, por exemplo, quantas vezes uma peça publicitária foi mostrada)

Muitas dessas métricas podem ser agregadas através de ferramentas de DA que mostram um panorama da presença receptiva (figura 4.2), a mais utilizada delas é o Google Analytics que pode ser instalada gratuitamente desde que o usuário insira um código de monitoramento (tags) no site. Outras ferramentas bastante disseminadas são Adobe Omniture e Webtrends. 


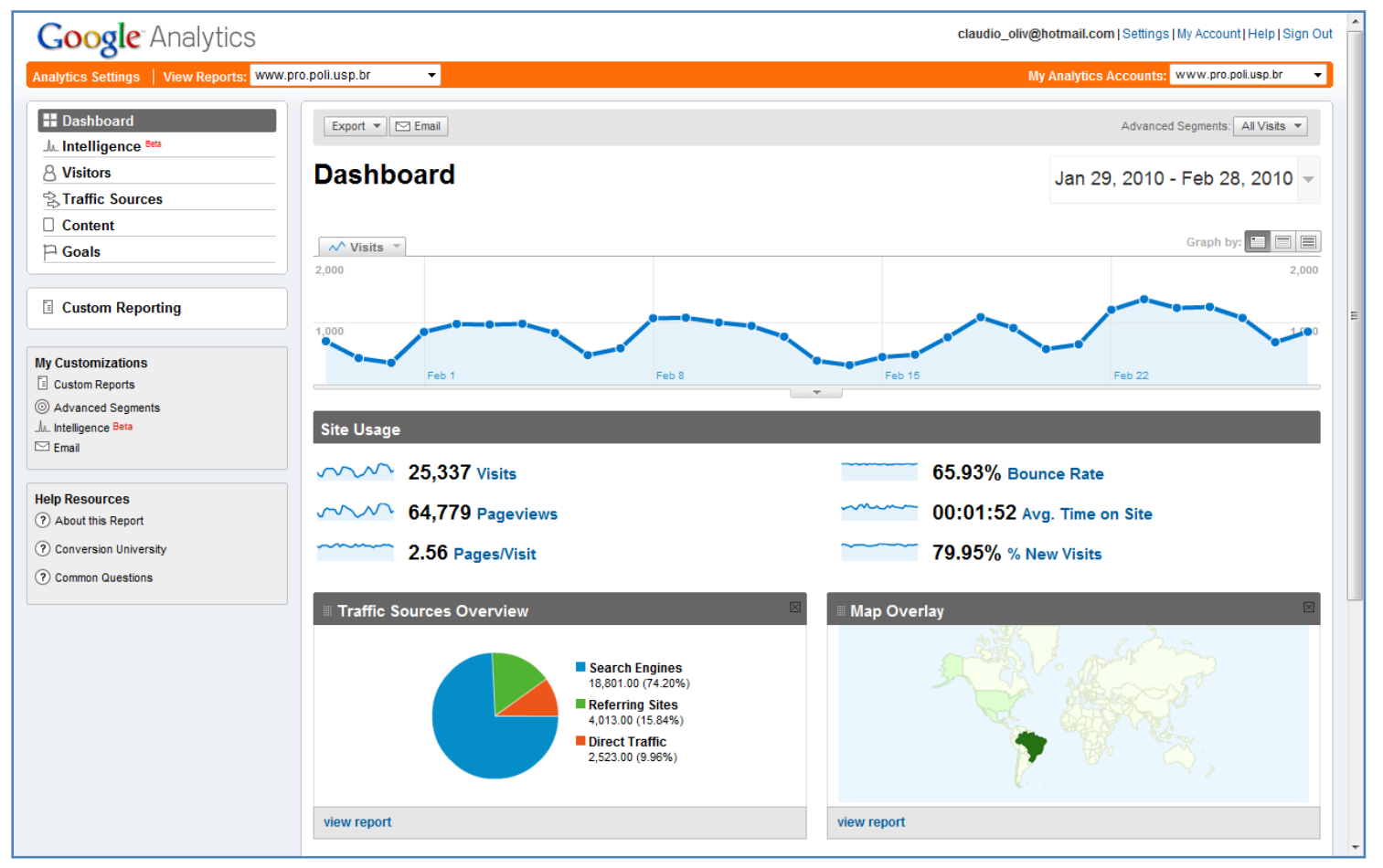

Figura 4.2: Painel de controle do Google Analytics

\subsubsection{Métricas para presença ativa}

Algumas métricas definidas para a presença receptiva podem ser utilizadas para a presença ativa, que são as campanhas e esforços de comunicação para trazer o usuário ao site.

- Impressões - número de vezes que um determinado conteúdo foi entregue para o usuário. Supondo um veículo de mídia (exemplo: site uol) que tenha um espaço pré-definido para campanha publicitária, o número de impressões é o numero de vezes que uma peça (banner ou pop-up) foi exibida para o usuário final.

- Click-through - número de vezes que um link foi clicado por um visitante. Se um consumidor clicou num link de peça publicitária e chegou ao site do anunciante, conta-se um clique-through.

- Click-through rate (CTR): número de clique-throughs para um link específico dividido pelo número de vezes que esse link foi visualizado. A média do mercado brasileiro é de 0,27\%.

- Cobertura: Número de pessoas que viram as peças. Pode ser considerado uma ampliação do conceito de visitantes únicos voltado para campanhas. 
- Frequência: Média de vezes que cada usuário viu a peça publicitária. Conceito importante em publicidade, quanto mais vezes o usuário visualiza uma peça, maiores são as chance de que lembre do produto ou marca anunciados.

- Conversão pós-clique: Ações realizadas no site por pessoas que clicaram no banner. Por exemplo, número de cadastros gerados por cliques em peças publicitárias.

\subsubsection{Métricas para mídias sociais}

A McDermott et al. (2010) também definiram termos relacionados às mídias sociais. As análises de mídias sociais são bastante diferenciadas devido a diversidade de aplicações que compões essas mídias. Os principais termos listados são:

- Widgets: aplicativos utilizados pelos usuários que podem ser replicados e rastreados pela fonte que o desenvolveu.

- Visualizações: número de vezes que um widget é carregado.

- Bookmark social: URLs compartilhadas online

- Publicações (posts): publicações autorais em posts e blogs

- Comentários: comentários em resposta às publicações

- Inbound links: URLs que direcionam para o blog do usuário

- Comentários por post: taxa que mensura a repercussão de um post

\subsubsection{KPls e consolidação das métricas}

Segundo a Digital Analytics Association (WAA, 2008) os dados podem ser organizados em:

- Medidas: o tipo mais básico de métrica representada por um número. É tudo que pode ser contabilizado, dividido, somado, colocado em gráficos.

- Taxa: uma métrica derivada obtida dividindo-se um número por outro. Por exemplo, a taxa de cliques de uma propaganda na Internet que é o número de cliques na propaganda versus o número de vezes que ela apareceu (impressões). 
- Dimensão: uma categoria contextualiza as medidas. Por exemplo, total de visitantes por estado, a quebra por estado é uma dimensão.

A tabela 4.1 apresenta uma organização dos termos listados por Digital Analytics Association (WAA, 2008) classificando-os como medidas, taxas ou dimensões.

Segundo Peterson (2006), os indicadores chave ou Key Performance Indicators (KPls) são médias, percentuais, taxas e conversões relacionados à eficácia do negócio. O autor lista diversos KPIs para Digital Analytics (tabela 4.1 e 4.2). Peterson (2006) defende a integração dos indicadores com a gestão de negócios da empresa, sendo prescritivo ao recomendar iniciativas que promovam o alinhamento entre a área técnica e de negócios. Uma de suas recomendações é a importância de segmentar os KPls por nível de tomada de decisão. Essa segmentação é relevante, pois cada público possui necessidades particulares:

- Estrategistas seniores observam entre 3 e 5 KPls que mostrem diretamente os objetivos de negócios alcançados e a lucratividade da presença online.

- Estrategistas de nível médio são frequentemente requisitados quando problemas são detectados pelos executivos seniores. Portanto eles precisam, dos mesmos indicadores do executivo sênior, mas com nível de detalhe suficiente para tomar decisões sem chegar num nível extremamente técnico.

- Recursos táticos possuem autonomia para tomar decisões, porém agem dentro de um contexto mais específico. Normalmente, possuem compreensão profunda dos indicadores de Digital Analytics e precisam deles para tomar decisões operacionais.

Por esse motivo, ao propor KPls específicos para varejistas online, sites de conteúdo, sites de marketing e sites de suporte a clientes. Peterson (2006) recomenda KPIs desdobrados para recursos táticos, estrategistas de nível médio e estrategistas seniores. 
Tabela 4.1: Termos relacionados à DA (WAA, 2008, 2010)

\begin{tabular}{|c|c|c|}
\hline Categorias & Termos & Tipos de termos \\
\hline \multirow{5}{*}{$\begin{array}{l}\text { Elementos } \\
\text { básicos }\end{array}$} & Página & Dimensão \\
\hline & Visualização de página & Medida \\
\hline & Visitas & Medida \\
\hline & Visitantes únicos & Medida \\
\hline & Eventos & Dimensão e medida \\
\hline \multirow{9}{*}{$\begin{array}{l}\text { Caracterização } \\
\text { da visita }\end{array}$} & Página de entrada & Dimensão \\
\hline & Página de entrada relacionada à campanha online & Dimensão \\
\hline & Páginas de saída & Dimensão \\
\hline & Duração da visita & Medida \\
\hline & Origem do tráfego & Dimensão \\
\hline & Origem do tráfego para página & Dimensão \\
\hline & Origem do tráfego para visita & Dimensão \\
\hline & Clicks em links (click through) & Medida \\
\hline & Taxa de clicks (click through) & Taxa \\
\hline \multirow{7}{*}{$\begin{array}{l}\text { Caracterização } \\
\text { do visitante }\end{array}$} & Novo visitante & Medida \\
\hline & Visitante que retorna & Medida \\
\hline & Visitante repetido (durante o período do relatório) & Medida \\
\hline & Origem do tráfego para visitante & Dimensão \\
\hline & Visitas por visitante & Medida \\
\hline & Recência & Medida \\
\hline & Frequência & Medida \\
\hline \multirow{4}{*}{ Engajamento } & Taxa de saída por página & Taxa \\
\hline & Visitas onde usuário viu apenas uma página (bounce) & Medida \\
\hline & Taxa de bounces sobre total de visitas (bounce rate) & Medida \\
\hline & Páginas vistas por visita & Medida \\
\hline \multirow{2}{*}{ Conversão } & Conversão & Medida \\
\hline & Taxa de conversão (conversão sobre visitas) & Taxa \\
\hline \multirow{2}{*}{ Miscelânea } & Requisições ao servidor (hits) & Medida \\
\hline & Impressões & Medida \\
\hline \multirow[t]{7}{*}{ Mídias sociais } & Aplicativos (widgets) & Dimensão \\
\hline & Visualizações de aplicativos & Medida \\
\hline & Bookmark social & Medida e dimensão \\
\hline & Publicações (posts) & Medida \\
\hline & Comentários & Medida \\
\hline & Inbound links & Medida e dimensão \\
\hline & Comentários por post & Taxa \\
\hline
\end{tabular}


Tabela 4.2: KPIs para Digital Analytics (PETERSON, 2006)

\begin{tabular}{|c|c|}
\hline Tipos & KPIs \\
\hline \multirow{12}{*}{ Média } & Páginas por visitante \\
\hline & Visitas por visitante \\
\hline & Tempo para responder a solicitações por email \\
\hline & Custo por visitante \\
\hline & Custo por visita \\
\hline & Faturamento médio por visitante \\
\hline & Faturamento médio por visitante \\
\hline & Faturamento médio por visita \\
\hline & Número de itens por pedido \\
\hline & Click Through Rate (CTR) ou taxa de cliques sobre impressões \\
\hline & Média de visitas do consumidor anteriores à compra \\
\hline & Média de buscas por visita \\
\hline \multirow{13}{*}{ Percentuais } & Visitas novas e visitantes que retornam \\
\hline & Consumidores novos e que retornam \\
\hline & Visitantes dentro de um segmento específico \\
\hline & Visitas com de navegação alto, médio e baixo \\
\hline & Visitas com aprofundamento de cliques alto, médio e baixo \\
\hline & Frequência de visitação alta média e baixa \\
\hline & Recência de visitação alta média e baixa \\
\hline & Faturamento advindo de consumidores novos e que retornam \\
\hline & Pedidos advindos de consumidores novos e que retornam \\
\hline & Consumidores e visitantes com grau de satisfação alto e baixo \\
\hline & Visitantantes que utilizam buscas \\
\hline & Buscas que retornam zero itens \\
\hline & Buscas que levam a cliques em links \\
\hline \multirow{17}{*}{$\begin{array}{l}\text { Taxas } \\
\text { conversões }\end{array}$} & Conversão de visita em venda \\
\hline & Conversão de visitante em comprador \\
\hline & Conversão de visitante novos e de visitantes fiéis em compradores \\
\hline & Conversão de consumidores novos e de consumidores fiéis \\
\hline & Conversão de novos visitantes em visitantes fiéis \\
\hline & Conversão de pedidos por campanha \\
\hline & Conversão de visitantes que iniciaram o processo de compra \\
\hline & Conversão de visitantes que concluíram o processo de compra \\
\hline & Conversão de visitantes que iniciaram o checkout \\
\hline & Conversão de visitantes que concluíram o checkout \\
\hline & Taxa de checkout iniciados vs processos de compras iniciados \\
\hline & Permanência na página de início da visita \\
\hline & Conversão de visitas em informações encontradas \\
\hline & Conversão de visitas em que houve buscas em vendas \\
\hline & Conversão de visitas em que houve buscas em saídas do site \\
\hline & Taxa de downloads concluídos \\
\hline & Taxa de preenchimento de formulários \\
\hline
\end{tabular}


Os KPls expostos por Peterson (2006) são abrangentes, mas restringem-se à presença online gerenciada pela empresa. Outros indicadores procuram avaliar o engajamento do usuário nas mídias sociais, Berkowitz (2009) cita 100 formas de mensuração das mídias sociais, no entanto Sterne (2010) argumenta que essas métricas só fazem sentido se contribuírem para três objetivos de negócios: economia de custos, aumento de faturamento e/ou melhoria no relacionamento com o cliente/consumidor.

A profusão de web métricas infla os relatórios aumentando a dificuldade para obter insights de negócios (STERN, 2010), (ARUN et al, 2006). Por esse motivo, faz-se relevante à discussão a ser realizada nos próximos capítulos sobre um framework de análises relevantes de DA e sua possível integração com a gestão de negócios.

\subsection{Capacidade analítica}

Um dos constructos da pesquisa será a capacidade analítica, pois devido ao alto número de métricas existentes uma habilidade crítica será discernir qual informação será relevante para os negócios. Para apoiar essa capacidade serão detalhadas as seguintes variáveis: inteligência competitiva, otimização da presença ativa, análise de mídias sociais, usabilidade e convergência de canais.

\subsubsection{Inteligência competitiva}

Um dos desafios da implantação dos KPls é obter parâmetros que podem ser usados pelas empresas no estabelecimento de metas e objetivos estratégicos. Segundo Porter $(1979,1996)$, a empresa precisa entender o contexto da indústria em que está inserida e desenvolver estratégias que proporcionem uma vantagem competitiva frente aos concorrentes. Portanto, um parâmetro relevante para as análises pode ser o desempenho obtido pelos concorrentes nesses KPIs. No entanto, se faz necessário coletar informações dos concorrentes para estabelecer esses parâmetros (YANAZE, 2011, TARAPANOFF, 2004; KAUSHIK, 2009).

$\mathrm{Na}$ internet, existe uma série de fontes de informações que podem ser usadas para elaboração desse benchmark como empresas que oferecem relatórios de 
audiência de diversos sites baseados em pesquisa amostral. Através dessas pesquisas, é possível montar um painel comparativo do desempenho dos concorrentes conforme exemplo na figura 4.3.

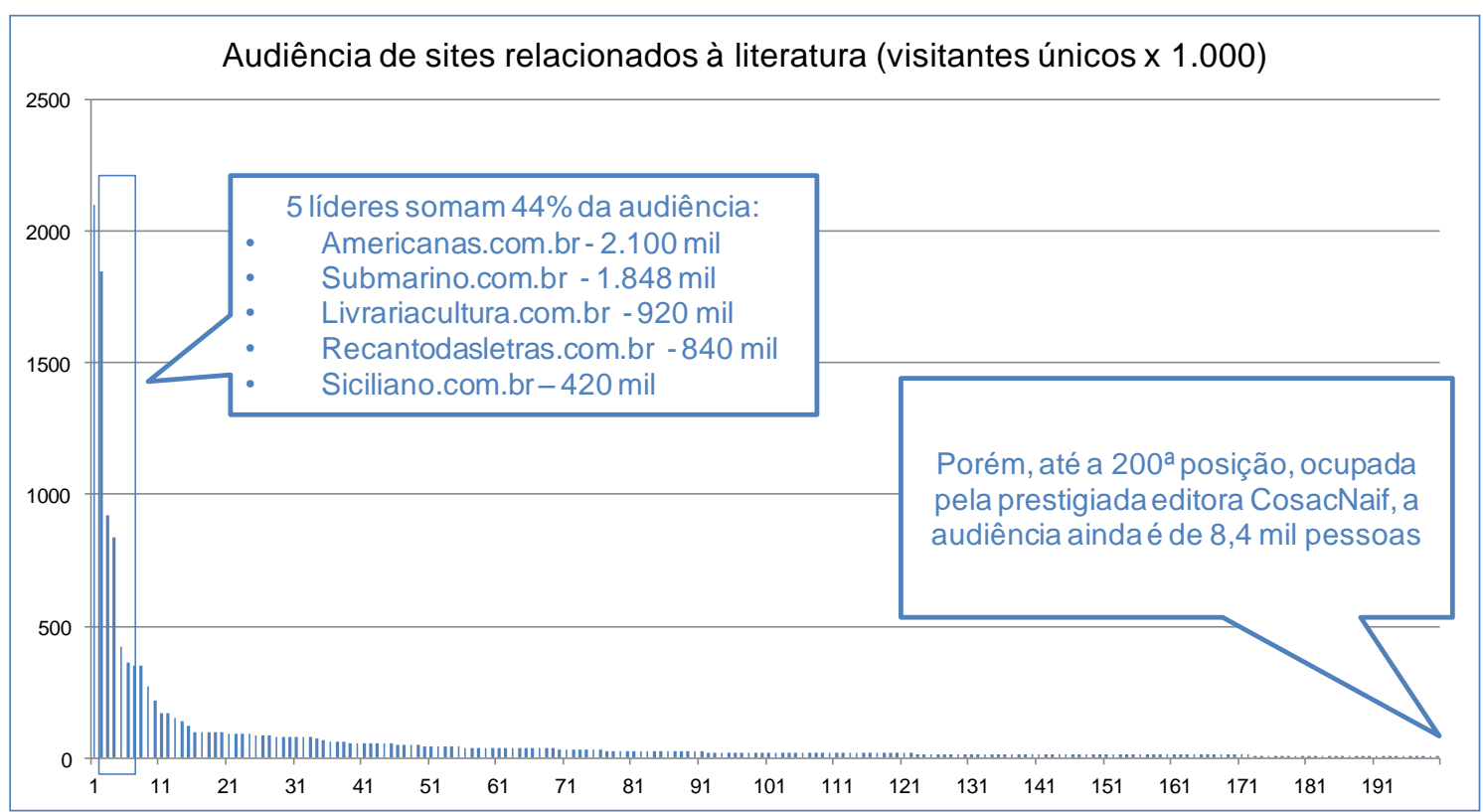

Figura 4.3: Audiência dos sites sobre livros (GOOGLE ADPLANNER, 2011)

As pesquisas também permitem uma análise profunda do mercado, onde podem ser identificadas tendências de consumo de mercados segmentados que são responsáveis por parte relevante do faturamento (BRYNJOLFSSON, 2003; ANDERSON, 2006). Na figura 4.3, estão representados sites que vendem livros e que também disponibilizam informações para leitores. Verificase que mesmo na $200^{\mathfrak{a}}$ posição, há um site com mais de 8.000 visitantes.

$\mathrm{O}$ acesso às pesquisas de mercado também permite dimensionar e identificar 0 perfil do público que navega em sites de determinado segmento. Por exemplo, ao se pesquisar o público total de brasileiros que compram livros ou buscam informações sobre literatura, registra-se um total de 9,1 milhões de pessoas. Sendo que 29\% têm menos de 18 anos, 32\% não possui ensino médio concluído, o que sinaliza que boa parte dos livros procurados devam ser didáticos, e a maioria é de homens (55\%) (figura 4.4). Esse tipo de informação é valiosa para elaboração de planos de negócios e precisaria de dispendiosas pesquisas de mercado, no entanto, foram encontradas gratuitamente em sites como o Google AdPlanner. 


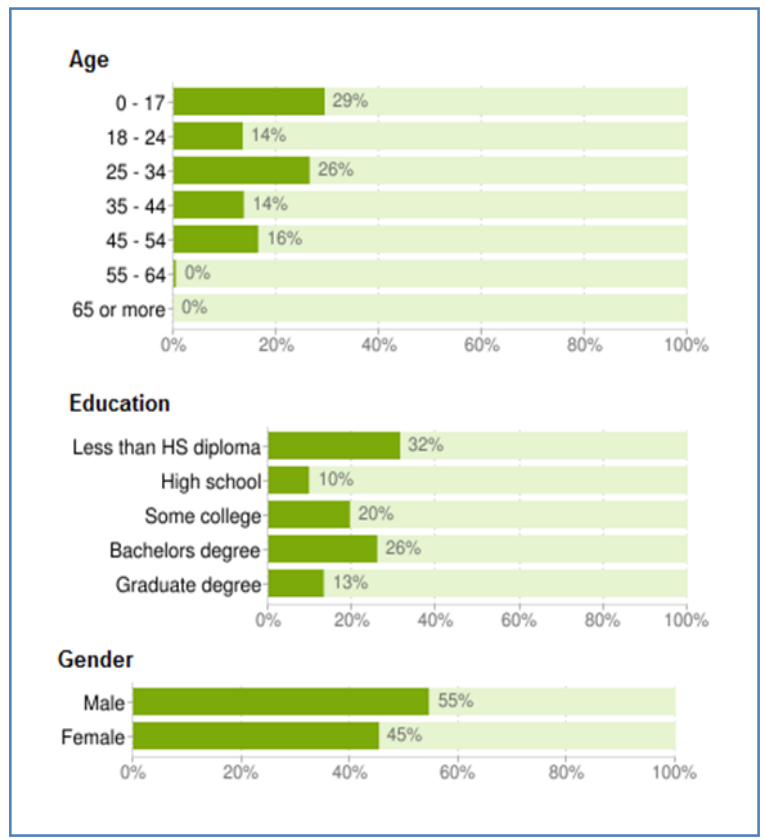

Figura 4.4: Tela do Google ApPlanner (2011) com perfil da audiência dos sites sobre livros Além da utilização de pesquisas de mercado, há outras fontes que podem servir para elaboração do benchmark como:

- Fichamentos detalhados da presença online dos concorrentes;

- Análises de palavras-chave mais buscadas pelo consumidor;

- Posição do site na busca orgânica do Google e também na área de links patrocinados;

- Comentários sobre produtos e serviços disponíveis nas mídias sociais;

- Bases governamentais e de associações de classe com painéis de mercado atualizados.

Os fichamentos são necessários para verificar as características da presença online dos concorrentes como fan pages, sites, blogs entre outros. Esse monitoramento deve ser periódico para que se possa notar a periodicidade de atualização do conteúdo. A verificação da forma de atendimento ao consumidor e tempo de resposta também são relevantes. Em sites de e-commerce, faz-se necessário mapear os preços e ofertas dos concorrentes.

A forma como a empresa comunica essa oferta para cada consumidor é uma variável importante para o fechamento de uma compra. Ao analisar sites de livrarias, nota-se que algumas empresas simplesmente "empurram" produtos, oferecendo livros que não correspondem aos gostos do consumidor. Outras 
empresas procuram mostrar ofertas mais próximas ao perfil do usuário do site, procurando promover um encontro entre oferta e necessidade do consumidor. A análise de palavras-chave que são buscadas com frequência pelo consumidor em ferramentas como o Google permite verificar a força da marca (KAUSHIK, 2012). A lembrança das marcas está relacionada a fatos relevantes como pode ser visto na figura 4.5 que mostra as livrarias mais buscadas no Google desde 2005 (GOOGLE TRENDS, 2012), nota-se que a marca Saraiva ganha força após a aquisição da Livraria Siciliano (TEIXEIRA, 2008) e que a marca Submarino, apesar de ter um portfólio maior de produtos, sofre com problemas na logística de seus produtos ocorridos a partir de 2011 (SAMPAIO, 2012) e passa a ter menos buscas de usuários na web.

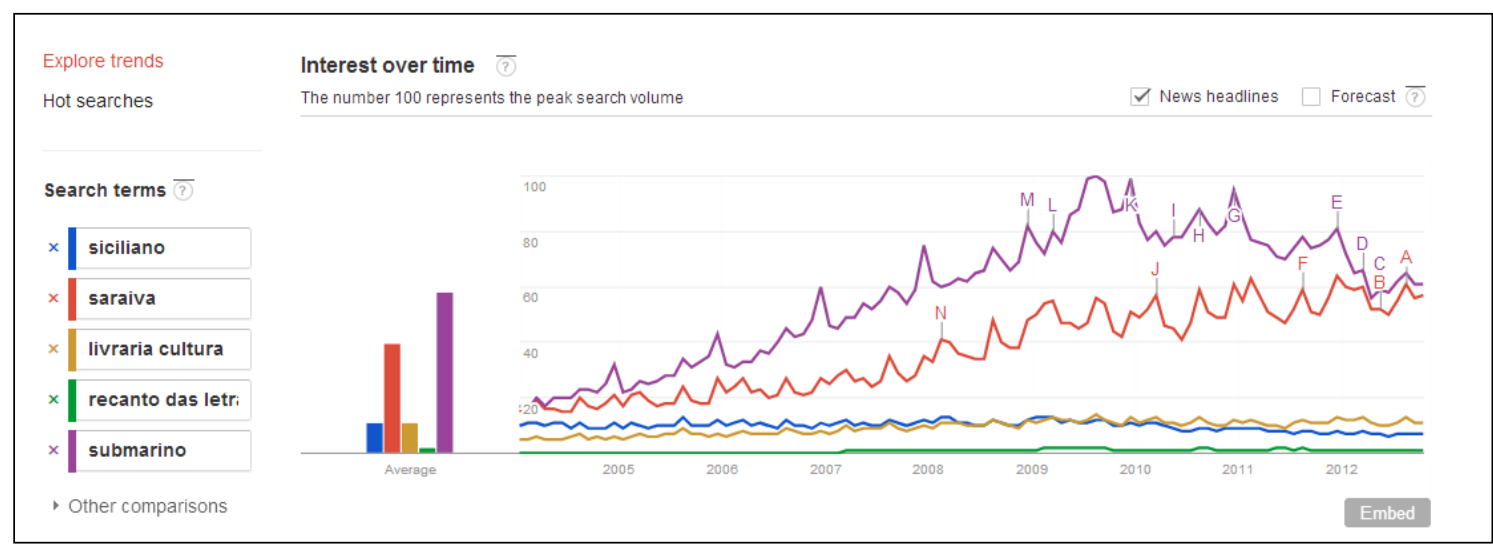

Figura 4.5: Comparação das marcas de livros mais buscadas no Google (GOOGLE TRENDS, 2012)

A posição que os sites se encontram nas buscas do Google (figura 4.6) também informa sobre como as marcas são competitivas na Internet. Sites que aparecem em primeiro lugar na busca orgânica (não paga) possuem maior credibilidade com o consumidor construída através usabilidade superior, produtos relevantes e links às suas páginas que são publicados em outros sites (FOX, 2010). Já os sites que aparecem em primeiro nos links patrocinados demonstram uma habilidade da empresa em otimizar seus investimentos em marketing digital.

Os comentários deixados em redes sociais demonstram o quanto o consumidor está satisfeito ou não com cada marca (figura 4.7). O mapeamento das opiniões dos consumidores em mídias sociais permite monitorar fatores críticos de sucesso como a satisfação com a logística, os comentários mostram como a empresa realiza suas entregas e se, eventualmente, ela ultrapassa os prazos 
combinados com o comprador. Através da análise desses comentários, também se pode perceber os motivos da (in)satisfação. Essa análise contribui para entender os pontos fortes e fracos de cada empresa baseado no ponto de vista do consumidor.

As bases governamentais e de entidades de classe atualizam informações relevantes para a inteligência competitiva, em indústrias como a automobilística, pode-se acompanhar as vendas mensais de cada marca pelo número de emplacamentos disponível no site da FENABRAVE (2012a).

A partir de um ponto vista mais amplo, em os movimentos dos concorrentes também influenciam a atratividade de suas indústrias (PORTER 1979; 1996) vale notar que as informações disponíveis na web influenciam o poder de barganha, pois fornecem as empresas compradoras um levantamento de preços atualizados, assim como, uma lista de fornecedores que podem atender à demanda em diversas partes do mundo.

Para as empresas que já transacionam com seus fornecedores, existem serviços disponibilizados pelo governo como a nota fiscal eletrônica que é utilizada por mais de 885 mil emissores, esse serviço disponibiliza relatórios das notas fiscais de compra da empresa (NOTA FISCAL ELETRÔNICA, 2012). Com essa informação, até mesmo pequenos negócios que não possuem sistemas corporativos, conseguem acompanhar a evolução da compra de insumos e a lista de aquisições por fornecedores.

\subsubsection{Otimização da presença ativa}

Para que o site da empresa tenha relevância é importante que possua um volume alto de audiência. Essa audiência pode ser gerada através de campanhas online, links em outros sites, cliques em mecanismos de busca, digitação da URL, retorno ao site via sites favoritos (bookmarks) armazenados no navegador do usuário ou campanhas através de mídias sociais (SCOTT, 2011).

As campanhas na internet podem ocorrer através de peças publicitárias divulgadas em veículos de mídia, patrocínio de vídeos na web, e-mail marketing entre diversas formas possíveis nesse meio tão flexível. Uma forma de campanha que vem se destacando nos últimos anos são os links 
patrocinados, que são os anúncios pagos em mecanismos de busca (figura 4.6). No mercado americano eles representam metade dos investimentos em mídia online (CAPPS, 2009). A técnica para otimização desse tipo de campanha é denominada search engine marketing (SEM).

Outra tática relacionada aos mecanismos de busca que é relevante para aumentar a audiência dos sites é o search engine optimization (SEO). O SEO procura aumentar a posição do site na busca orgânica (figura 4.6) dos mecanismos de busca. Pesquisas indicam que o usuário confia mais nos links disponíveis na busca orgânica, pois julga que as empresas estão nessa posição pela qualidade do conteúdo do site que é endossada por outros internautas (FOX, 2010).

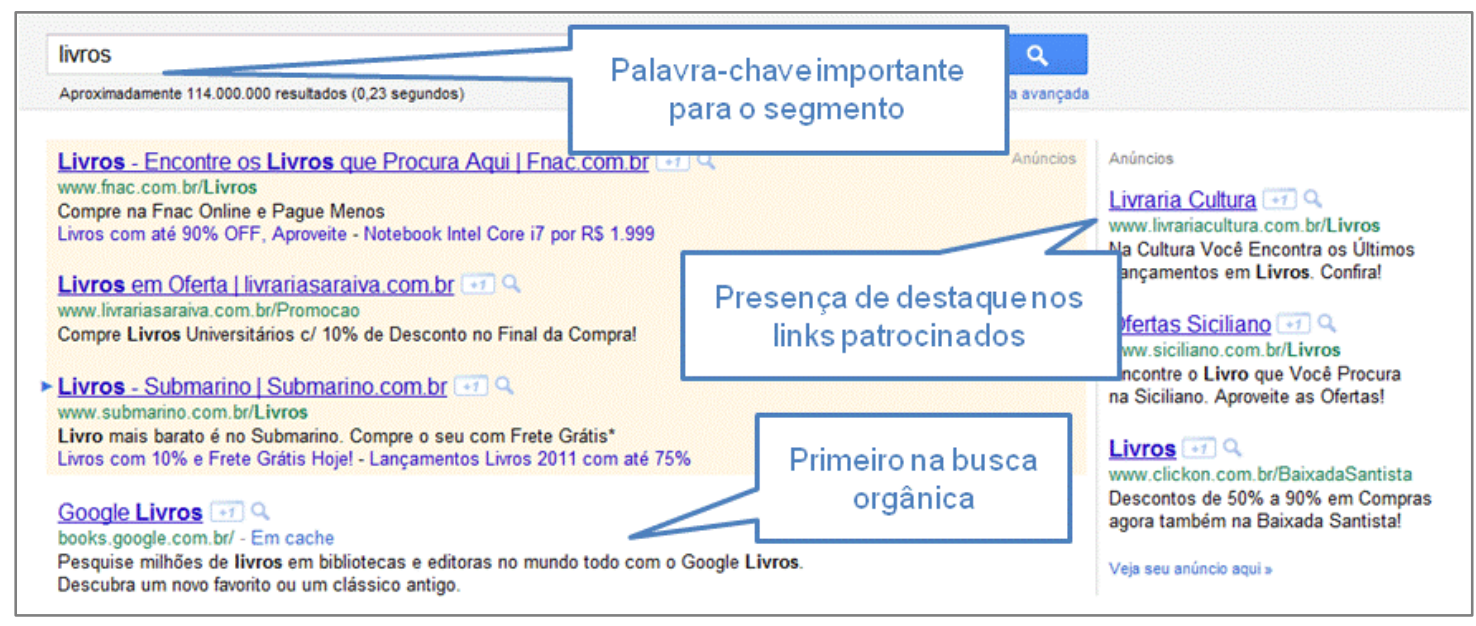

Figura 4.6: Resultados de busca no Google 


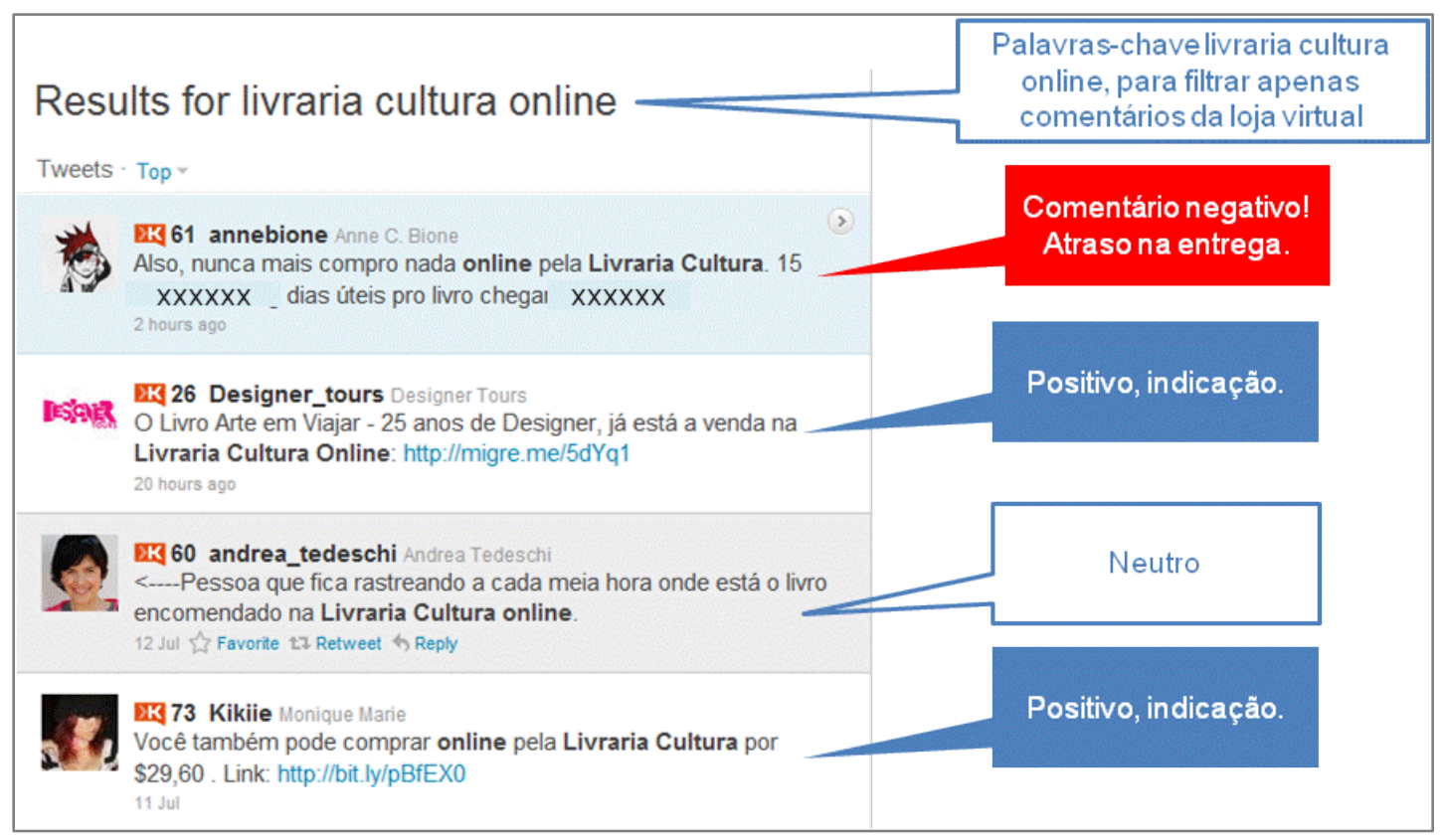

Figura 4.7: Comentários sobre a marca Livraria Cultura no Twitter

A medição da performance das campanhas digitais pode ser representada como uma pirâmide vinculando métricas de exposição - base da pirâmide, métricas estratégicas e métricas financeiras - topo da pirâmide (ver figura 4.8). As métricas de exposição determinam a cobertura, medida pelo número de visitantes que interagiram com o conteúdo na presença online da marca. As métricas estratégicas medem o quanto o usuário evoluiu na preferência pela marca e pode ser medida por pesquisas realizadas antes e depois da interação com a presença online. As métricas financeiras calculam as mudanças em vendas e ROI baseado no custo de exposição da marca (MAYAR \& RAMSEY, 2011). 


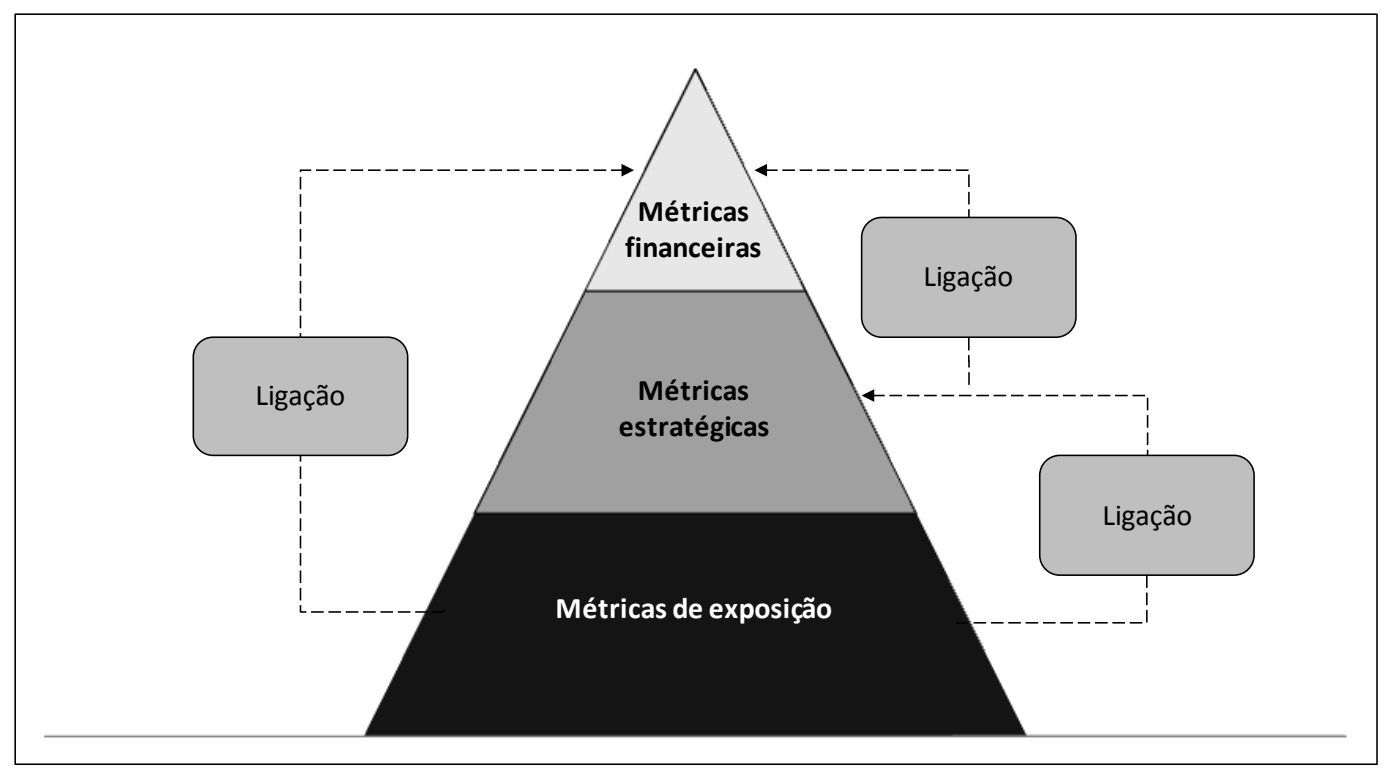

Figura 4.8: Framework de medição de performance digital (MAYAR \& RAMSEY, 2011)

Mayar e Ramsey (2011) acreditam que as campanhas digitais possuem os seguintes objetivos em comum independente dos canais em que são divulgadas: alcançar a audiência correta, engajar a audiência com conteúdo relevante, motivar a audiência para chegar a uma ação desejada (exemplo: compra, cadastro, visualização de demonstração), ser eficiente com relação aos gastos e gerar um ROI positivo. Baseado nesses objetivos, os autores propões sete métricas:

(i) Cobertura ou visitantes qualificados: quantidade de pessoas expostas à marca dentro do público-avo desejado;

(ii) Taxa de clicks, em inglês Click Through Rate (CTR): número de cliques sobre impressões da campanha;

(iii) Aumento na percepção da marca: qual o incremento de pessoas que afirmam conhecer a marca;

(iv) Grau de engajamento: quanto as pessoas se envolvem com a marca se engajando em comunidades em redes sociais ou defendendo-a em fóruns online;

(v) Taxa de ações finalizadas: conversão de visitas em ações como cadastro, compra e experimentação do produto ou serviço;

(vi) Métricas de custo por x, onde x pode ser: clicks, impressões, leads, compras ou engajamento;

(vii) Retorno sobre investimento.

FARRIS et al (2007) corroboram essas métricas e ressaltam a importância de métricas de exposição das campanhas (ex.: impressões) e de frequência, que é o número de vezes que a mesma campanha aparece para cada pessoa. 
A otimização do investimento dessas campanhas é crítica para a rentabilização dos esforços online. O retorno sobre investimentos em marketing é a principal preocupação dos executivos americanos com 58\% de menções, seguido na sequência por retenção de consumidores e lealdade à marca, ambas com 53\% (ANALYTICS \& MENG, 2010).

O custo pago por cliques, impressões ou patrocínios é constantemente avaliado e o retorno de cada campanha é comparado com seu custo para se mensurar o retorno sobre investimento. Para que os indicadores da mídia online melhorem continuamente é importante se montar um banco de dados com cases da categoria e também com o histórico de campanhas das empresas monitoradas (YANAZE et al., 2010).

\subsubsection{Mídias sociais}

Os consumidores possuem ampla variedade de mídias onde publicar seus depoimentos sobre produtos e serviços: redes sociais, blogs pessoais, sites de defesa do consumidor como o Reclame Aqui e mais recentemente, serviços como o Twitter que publica depoimentos instantâneos de até 140 caracteres que podem ser inseridos e lidos inclusive de celulares.

Os comentários feitos pelos consumidores possuem correlação com as vendas nos sites conforme estudo sobre as publicações dos usuários no site da Amazon (CUI e GUO, 2009).

O acompanhamento desses depoimentos é utilizado para captar reações dos consumidores sobre lançamento de produtos, impressões sobre campanhas e repercussão sobre mudanças na marca. As reações aos movimentos dos concorrentes também são acompanhados. Através do Social CRM, as empresas montam estratégias de negócio que impulsionam vendas e serviços ao consumidor, enquanto beneficia as comunidades digitais (GARTNER, 2012)

O maior desafio para acompanhar esses depoimentos é o alto volume de dados. Para viabilizar a análises, apenas os depoimentos que possuem maior influência são captados. Sendo que o critério para influência de blogs é o número de citações em outros sites (LIMA et al., 2005), já nas redes sociais, a 
influência é medida pelo total de pessoas conectadas ao perfil do usuário, 0 quanto suas publicações são amplificadas e quão influentes são seus seguidores (KLOUT, 2012).

Além dos depoimentos feitos em blogs e redes sociais, a criação e divulgação de vídeos, o monitoramento do uso de $Q R$ Codes e a realização de check-ins em aplicativos como o Four Square são exemplos de interações em mídias sociais (SPONDER, 2012). Essas interações podem ser monitoradas ampliando a geração de insights sobre o consumidor (KAUSHIK, 2010).

Através dessas interações, são feitas análises qualitativas mapeando o conhecimento gerado pelo consumidor, como suas percepções sobre os atributos da marca (STERN, 2010) como se pode notar na figura 4.9.

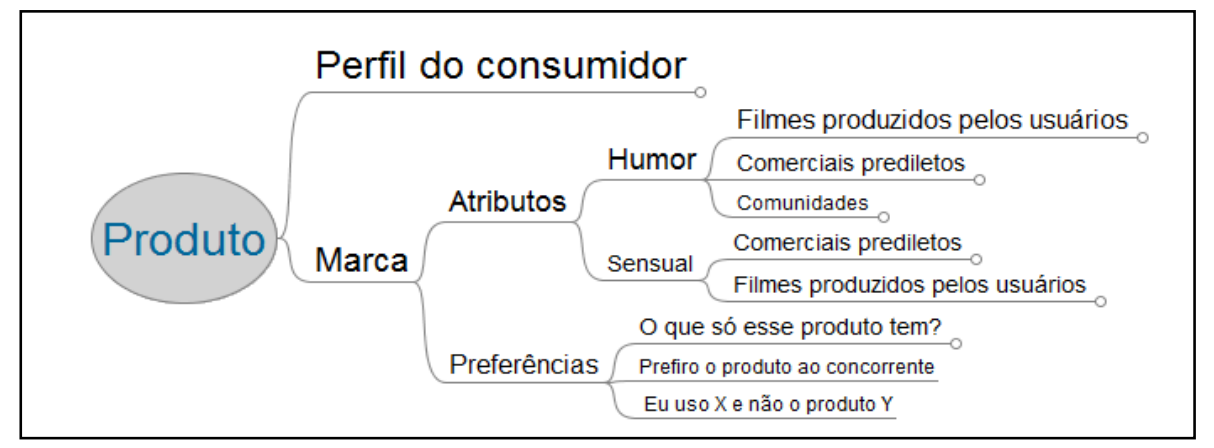

Figura 4.9: Exemplo ilustrativo dos tributos da marca de determinado produto (Tamanho das fontes representa frequência dos comentários associados)

\subsubsection{Usabilidade}

O conceito de DA surgiu com a criação de ferramentas de monitoramento sobre da audiência na web. Essas ferramentas eram baseadas em análises do log do servidor e bastante centradas na análise do site, pois uma das preocupações era com a performance da infra-estrutura do site.

Essa origem fez com que DA se ocupasse de métricas centradas no site afastando-se da satisfação do usuário do site. Recentemente, tem se fortalecido uma abordagem em que o consumidor passa a ser o centro do processo (KAUSHIK, 2009). 
Considerando-se o site um mecanismo de geração de resultados a partir das visitas, o consumidor passa a ser o centro das atenções de um processo que envolve a aquisição, a persuasão e a conversão. Esse processo deve funcionar de forma integrada e homogênea evitando gargalos que podem deixá-lo disfuncional (figura 4.10) (KAUSHIK, 2009, CUTLER \& STERNE, 2000).

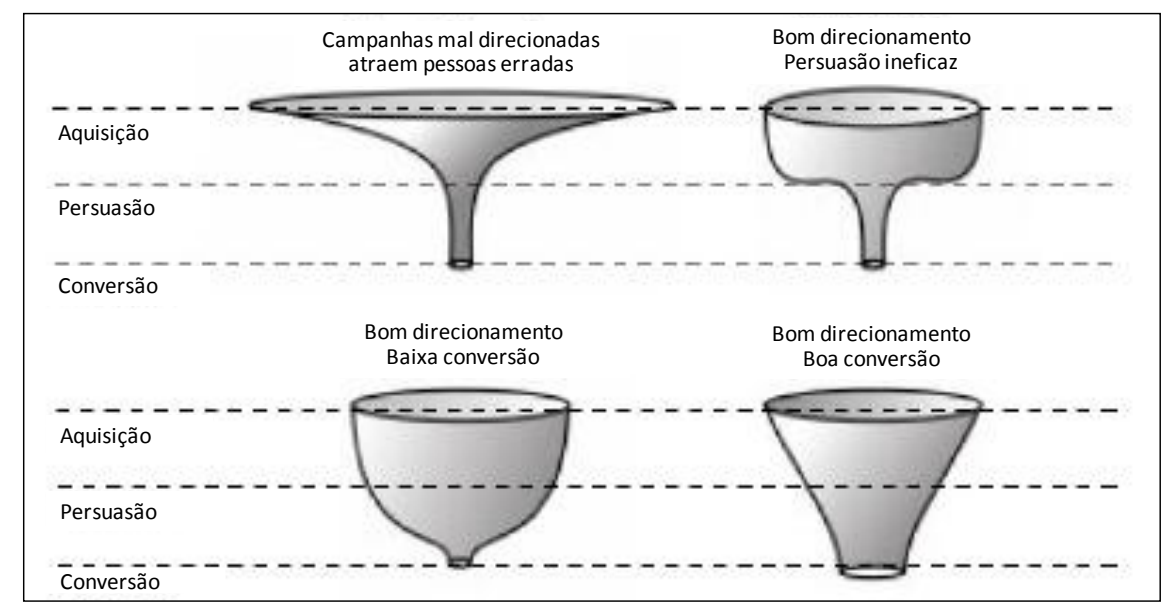

Figura 4.10: Funil de conversão do consumidor (CUTLER \& STERNE, 2000)

Para que os anseios do consumidor possam ser mapeados, não bastam os relatórios de análise da audiência. São necessárias pesquisas qualitativas, testes A/B e integração com informações de outros canais (KAUSHIK, 2009).

A empresa precisa estar comprometida com um plano de melhoria contínua da presença online, pois os resultados das análises devem rapidamente gerar evoluções no site que através de novas verificações podem gerar outros ajustes, conforme um ciclo Plan-Do-Check-Action PDCA (DAVIS et al., 2001)

\subsubsection{Convergência}

Caso as ações online sejam integradas com os esforços de comunicação offline, é possível que sinergia e os resultados somados das ações seja maior que $\mathrm{o}$ das ações realizadas isoladamente. Um estudo demonstrou que $60 \%$ das vendas online na Europa envolvem um ponto de contato offline, seja por conhecimento de marca (Ex.: conhecimento da marca através de comercial na TV) ou por ação dirigida (Ex.: um anúncio orientava o consumidor a visitar o site). 
As ações entre os diversos canais relacionam-se entre si e impactas o varejo e os fabricantes que por sua vez também influenciam as ações online conforme modelo ilustrado por Shankar \& Yadav (2010) (figura 4.11).

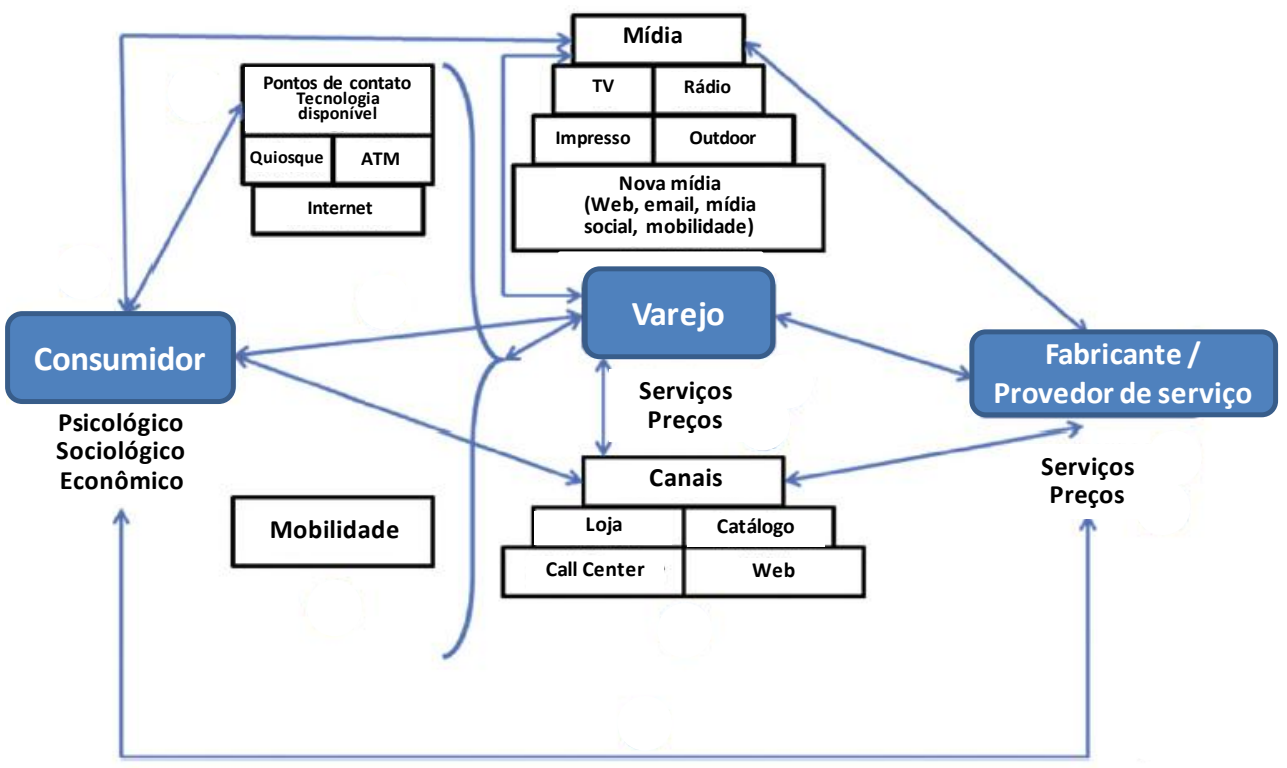

Figura 4.11: Um framework organizacional para marketing em múltiplos canais e ambiente multimídia de varejo (SHANKAR \& YADAV, 2010)

\subsection{Elementos de gestão de negócios relacionados à DA}

A integração das métricas de DA à gestão do negócios é importante para garantir o alinhamento estratégico de DA e também para que as análises tirem proveito de práticas consagradas no meio corporativo. Os elementos de gestão de negócios que serão analisados serão o planejamento estratégico, a gestão da qualidade, o customer knowledge management e o retorno de investimento em comunicação.

\subsubsection{Planejamento estratégico}

Uma das grandes dificuldades dos gestores é entender os dados das operações de internet, segundo Lemmens et al. (2001), embora muitas empresas de comércio eletrônico coletem dados de custo e uso de sites na internet, poucas têm uma compreensão aprofundada de como esses dados podem ajudar a medir o desempenho deles ou compará-los ao desempenho dos sites concorrentes. 
O conjunto das informações de DA permite capturar detalhes que vão além do óbvio e ajudam a elucidar o fluxo sistêmico de marketing (Figura 4.12) dos concorrentes baseados em seus inputs, througputs e outputs (YANAZE, 2011).

- outputs são os fatores: produto, preço, distribuição e comunicação;

- througputs são os processos, sistemas, políticas, assim como fatores internos que os sustentam como cultura organizacional, clima empresarial e logística;

- inputs são o conjunto de recursos financeiros, humanos e materiais apoiados pela informações e tecnologias.

EMPRESA

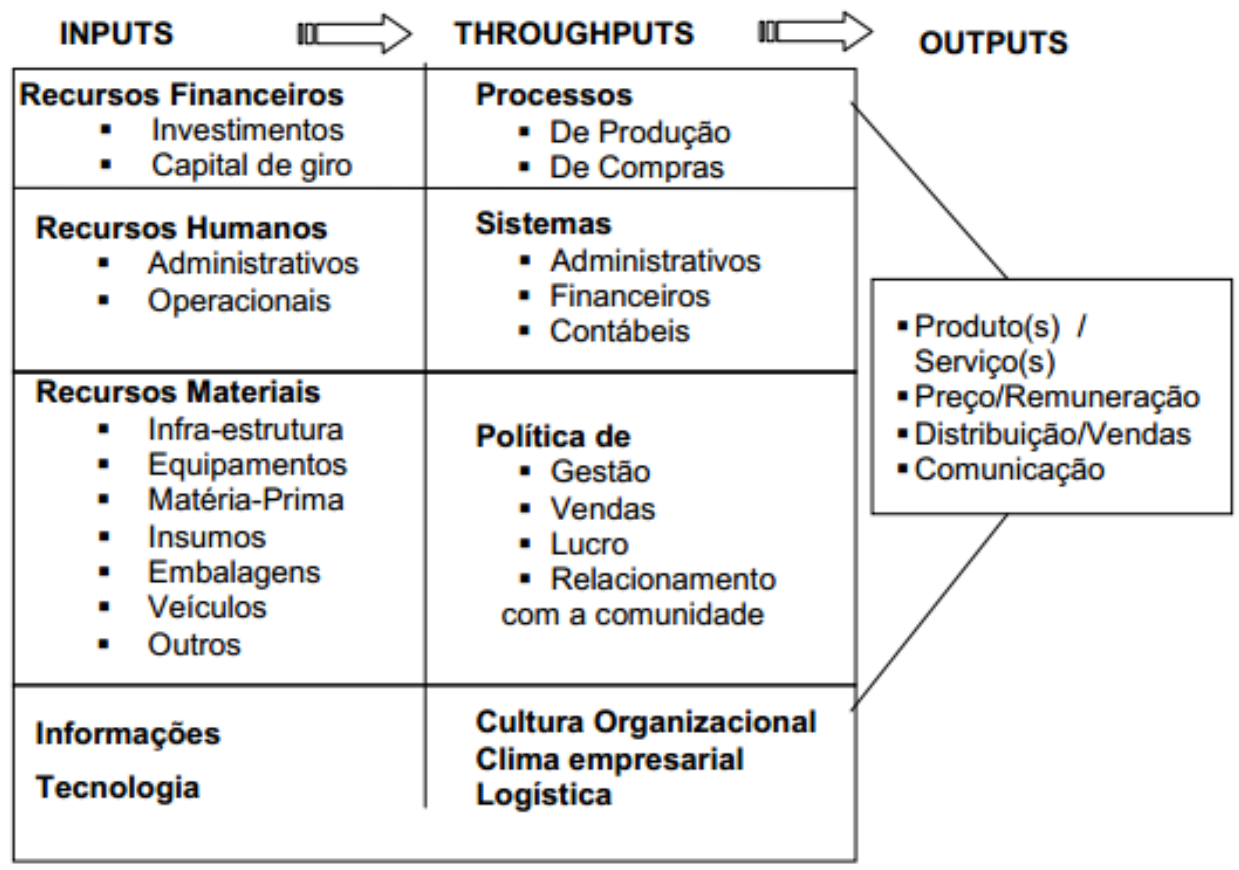

Figura 4.12: Fluxo sistêmico de marketing (YANAZE, 2011)

Yanaze (2011) propõe um modelo de análise para estabelecer objetivos, metas e estratégias de planejamento mercadológico baseado na análise desses inputs, througputs e outputs.

Uma das análises propostas pelo modelo é a matriz de crescimento e participação (MCP), ela permite estender a análise a três níveis: mercado, faturamento e margem de contribuição.

Uma aplicação da matriz MCP é a análise do crescimento e participação do faturamento gerado pelos 4 grandes clubes de São Paulo (PAVAN et al., 2012). Como pode ser visto na figura 4.13, tanto o crescimento quanto a participação são quantificados de forma precisa baseada nos dados de cada clube. 
Uma dificuldade que se coloca para esse tipo de análise é a indisponibilidade das informações de vendas dos concorrentes. A variável de audiência dos sites pode ser considerada um sinal (proxy) de faturamento em sites de ecommerce, ela pode ser consolidada a partir de pesquisas de audiência como Ibope Nielsen NetRatings (2012) e ComScore (2012). É possível monitorar a audiência dos concorrentes e também saber o percentual de clientes que logaram na área segura do site, com esses números, pode-se estimar o total de compradores no site em determinado mês (visitantes $x$ percentual de visitantes na área restrita). Para se quantificar o faturamento, pode-se basear no ticket médio de mercado fornecido por pesquisas como WebShoppers (2012).

Para que uma operação de internet constitua uma vantagem competitiva, os indicadores de desempenho devem estar alinhados com a estratégia da corporação. Além disso, os objetivos e metas devem ser claros a todos os funcionários para que a empresa foque seus esforços numa única direção.

O Balanced Scorecard (BSC) é um sistema de gerenciamento que permite a visão e as estratégias da organização fiquem claras, bem como permite que estas se transformem em ação (KAPLAN \& NORTON, 1997). O BSC fornece um feedback sobre os processos internos e sobre os resultados externos, a fim de buscar, continuamente, uma melhor performance estratégica e melhores resultados.

O BSC é dividido em quatro perspectivas: financeira, clientes, processos internos e inovação e aprendizado. Cada perspectiva possui objetivos, indicadores, metas e iniciativas associadas. As 4 dimensões são encadeadas entre si e também a visão e a estratégia da empresa como podemos notar na figura 4.14 . 


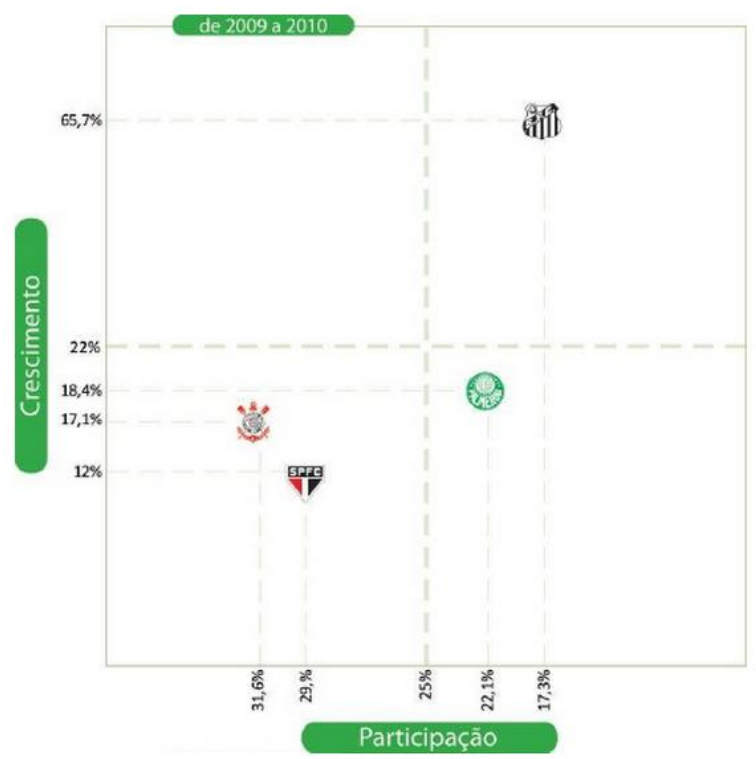

\begin{tabular}{|c|c|c|c|c|c|}
\hline Produtos/Ano & 2008 & Crescimento & 2009 & Crescimento & 2010 \\
\hline & & & & & \\
\hline \multirow{2}{*}{ Corinthians } & $24,30 \%$ & \multirow{2}{*}{$54,70 \%$} & $33,00 \%$ & \multirow{2}{*}{$17,10 \%$} & $31,60 \%$ \\
\hline & 117 milhões & & 181 milhz̃es & & 212 milhžes \\
\hline \multirow{2}{*}{ Palmeiras } & $28,70 \%$ & \multirow{2}{*}{$-9,50 \%$} & $22,70 \%$ & \multirow{2}{*}{$18,40 \%$} & $22,10 \%$ \\
\hline & 138 milhŏes & & 125 milhŏes & & 148 milhōes \\
\hline \multirow{2}{*}{ Santos } & $13,60 \%$ & \multirow{2}{*}{$7,60 \%$} & $12,70 \%$ & \multirow{2}{*}{$65,70 \%$} & $17,30 \%$ \\
\hline & 65 milhōes & & 70 milhōes & & 116 milhōes \\
\hline \multirow{3}{*}{ Săo Paulo } & $33,40 \%$ & \multirow{2}{*}{$8,70 \%$} & $31,60 \%$ & \multirow{2}{*}{$12 \%$} & $29,00 \%$ \\
\hline & 160 milhǒes & & 174 milhöes & & 195 milhöes \\
\hline & 480 milhöes de faturamento & $14,58 \%$ & 550 milhōes de faturamento & $22,00 \%$ & 671 milhōes defaturame \\
\hline
\end{tabular}

Figura 4.13: MCP de faturamento dos 4 grandes clubes de São Paulo (PAVAN et al., 2012)

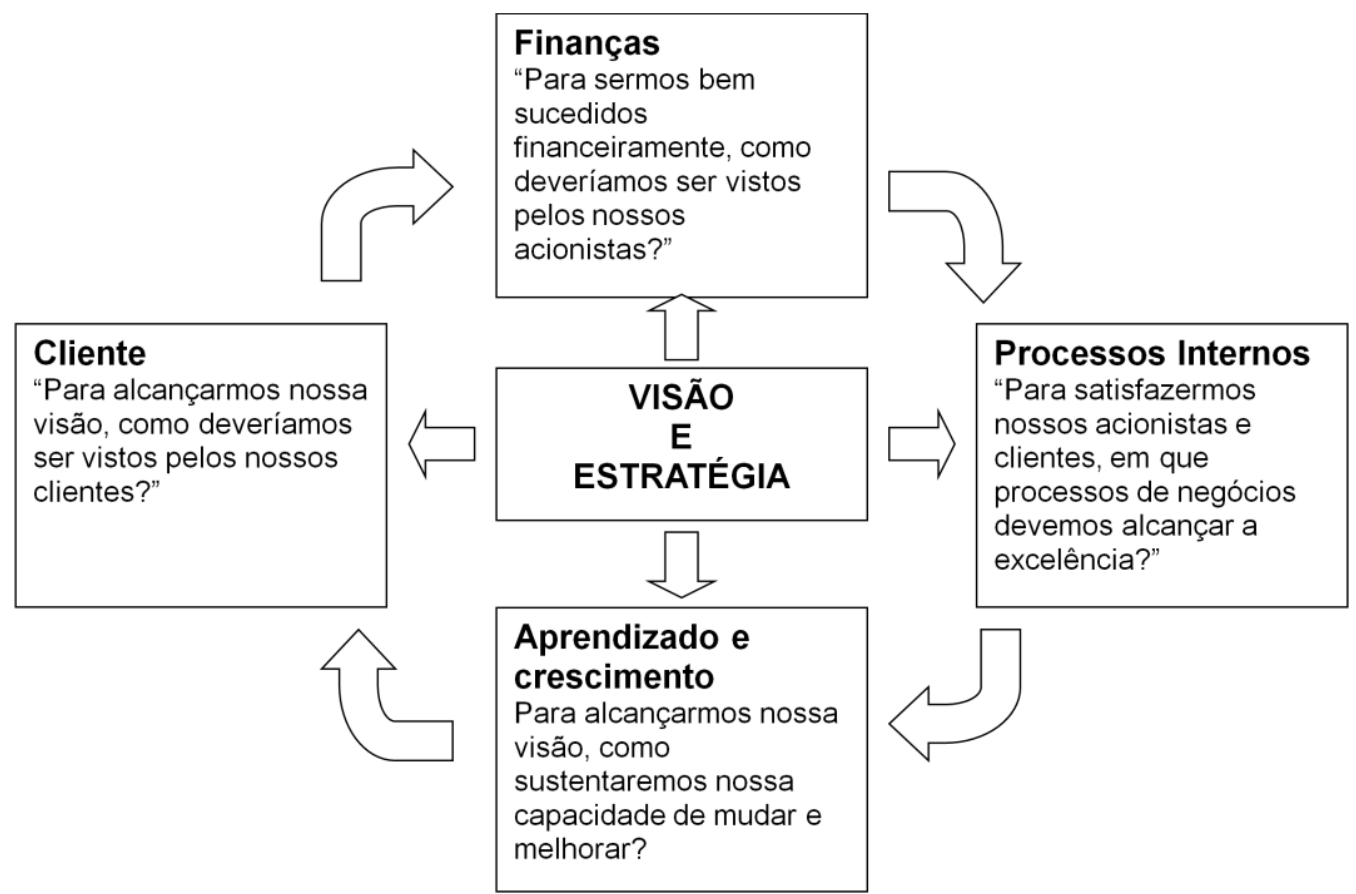

Figura 4.14: Relação entre as perpectivas do BSC (Adaptado de KAPLAN \& NORTON, 1997) 


\subsubsection{Controle da qualidade}

Os sistemas de controle da qualidade possuem ampla base teórica e prática, tendo sido implantados pela primeira vez em empresas japonesas após a segunda guerra mundial como parte do plano Marshall (DAVIS et al., 2001).

As contribuições entre DA e controle da qualidade podem acontecer nos dois sentidos, por um lado DA pode contribuir fornecendo métricas sobre os consumidores. De outro lado, as ferramentas da qualidade podem impulsionar as análises de DA.

As métricas sobre os consumidores podem contribuir para configurar a voz do cliente, conceito importante na formação do quality function deployment (QFD) que une os itens que constituem o produto/serviço, o grau de importância que o cliente atribui a cada item, a eficiência dos processos da empresa e o desempenho de cada item versus a concorrência (figura 4.15) (DAVIS et al., 2001).

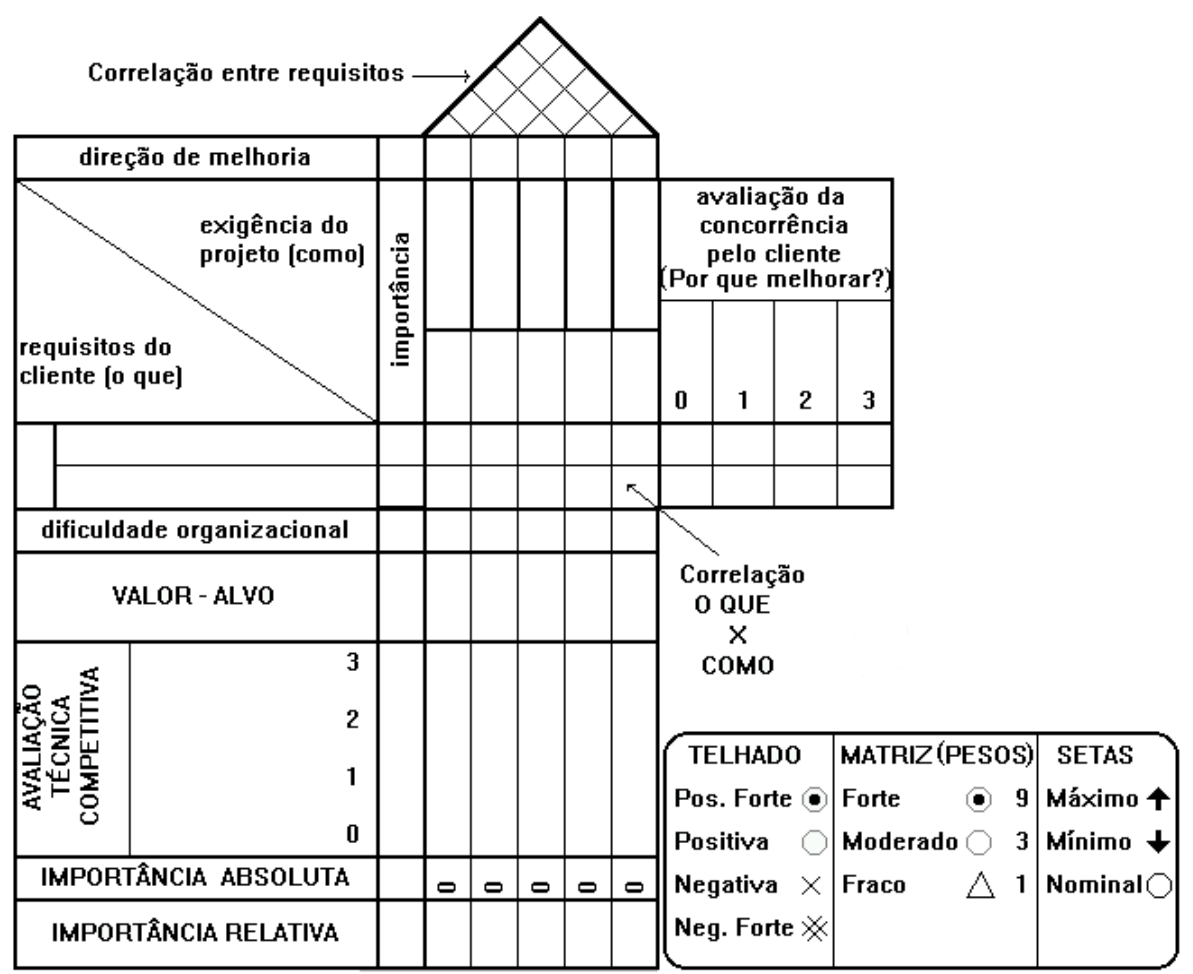

Figura 4.15: Quality function deployment (QFD) (SELNER, 1999)

As sete ferramentas da qualidade (figura 4.16) por sua vez, podem contribuir para dar direcionamento, estabelecer relações de causa e efeito e conferir consistência estatística aos estudos de DA. 

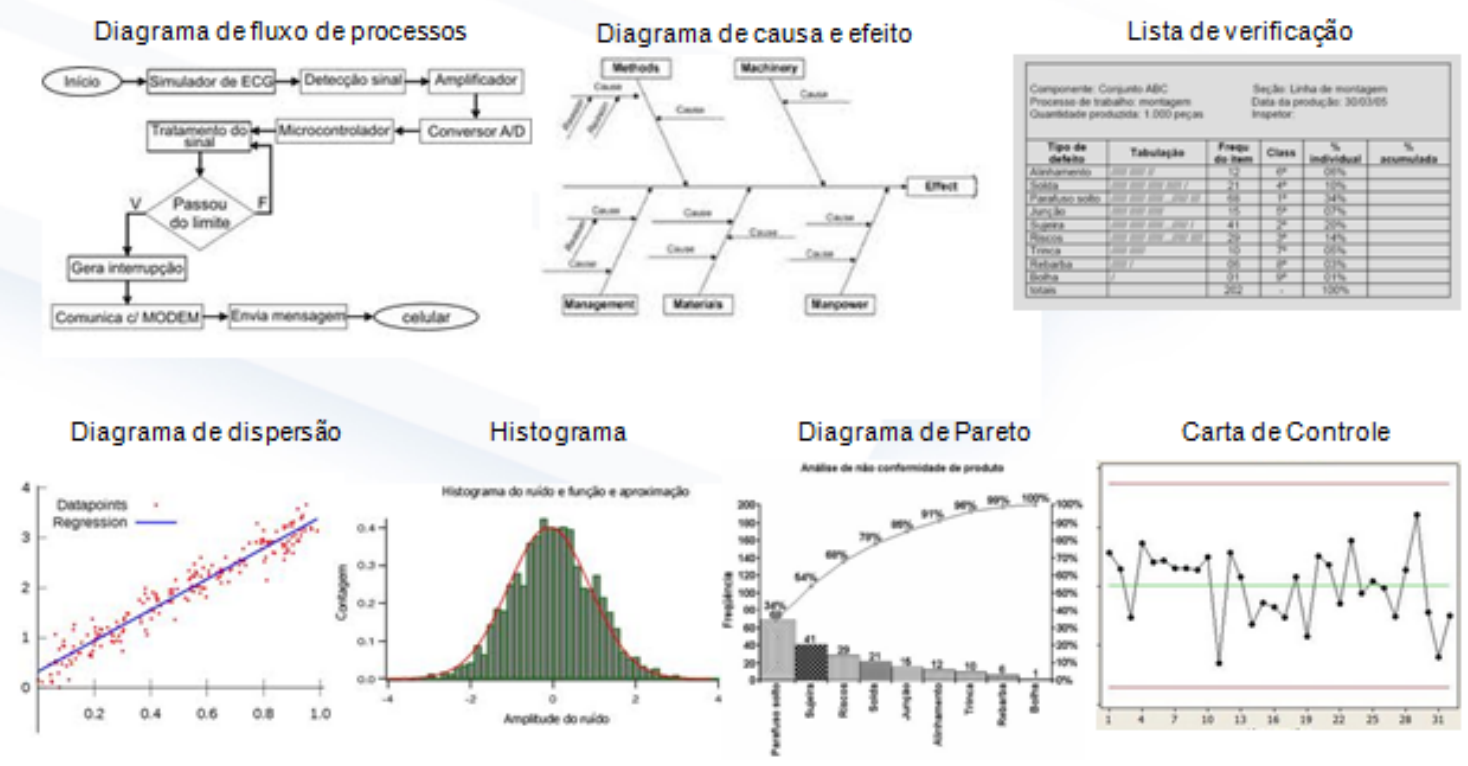

Figura 4.16: Sete ferramentas da qualidade (DAVIS et al., 2001)

\subsubsection{Customer Knowledge Management}

A gestão do relacionamento com o consumidor passou do tradicional costumer relationship management (CRM), onde hábitos de consumo e histórico de atendimento eram analisados, para o customer knowledge management (CKM) (tabela 4.3) que analisa o conhecimento gerado pelo próprio consumidor através de interações no site da empresa ou nas redes sociais, onde o próprio internauta produz seu conteúdo. Nesses locais é possível detectar a opinião declarada do consumidor que informa seus interesses, a satisfação com produtos e serviços, e sua opinião sobre a empresa e seus concorrentes (GIBBERT et al., 2002).

O conceito do CKM foi percebido através de uma experiência de sucesso com uma companhia de seguros sul-africana denominada Old Mutual (uma das 100 empresas com ações mais representativas na Bolsa de Londres). Essa empresa conseguiu mudar seus produtos e serviços baseada no conhecimento sobre a saúde dos pacientes e de seus tratamentos obtido diretamente através de meios eletrônicos, em vez de confiar apenas nas informações passadas pelos médicos (GIBBERT et al., 2002).

A Old Mutual conseguiu implantar o CKM através da disponibilização de formulários preenchidos diretamente pelos clientes (obviamente, exames médicos continuaram sendo prescritos pelos doutores) com as seguintes 
vantagens: (i) velocidade; (ii) consistência nos dados (formulários eram preenchidos manualmente pelos médicos, os autores chegam a mencionar que a má caligrafia era uma barreira); (iii) mais informações e, especialmente, mais conhecimento gerado pelos próprios pacientes. Esse conhecimento aumentou os inputs sobre a condição do paciente, assim como o tratamento e efeitos de algumas drogas. Também melhorou a percepção dos serviços médicos e seus produtos, sendo valioso para empresas farmacêuticas, companhias de seguros, doutores e outros interessados na indústria da saúde.

Gibbert et al. (2002) pontuam que o conhecimento que importa para o CKM é aquele que "reside" nos consumidores em contraponto ao conhecimento "sobre" os consumidores gerado pelo customer relationship management (CRM). Os autores defendem também a diferenciação do conceito de Knowledge Management (KM), pois o KM procura aproveitar o conhecimento dos funcionários para que não se tente reinventar a roda, aumentando a eficiência da empresa. O CKM por sua vez, está focado na eficácia, gerando vantagem competitiva a partir do conhecimento do cliente como pode ser notado na tabela 4.3 .

A relação do CKM com a estratégia corporativa e a construção de links mais fortes com a cadeia de valor (PORTER, 2001; BOVET \& MARTHA, 2001) ficam claros no caso da produtora de cimento Holcim (GIBBERT et al., 2002). A empresa montou uma plataforma onde uma comunidade de consumidores de cimento e agregados (produtores de concreto, distribuidores, arquitetos e engenheiros) podia não só realizar transações, como também podiam trocar conhecimento como previsões e experiências sobre aplicações do material. $O$ conhecimento adquirido impactou as ofertas da empresa para cada nicho de consumidores e reverteu num ótimo ganho de imagem, uma vez que os consumidores se sentiram ouvidos e suas demandas transformadas em produtos e serviços.

Essa geração de insights também ocorre através de mecanismos de busca como o Google, quando o consumidor busca informações sobre um produto ou uma empresa está sinalizando gostos e preferências que podem ser utilizados na melhoria das ofertas disponibilizadas no site (FOX, 2010), em estudos 
aprofundados sobre força da marca (KAUSHIK, 2012) e como informação para benchmarks.

Essas contribuições são ativos intangíveis e sua gestão representa uma competência essencial,esses ativos precisam estar presentes na organização como condição necessária para se construir um diferencial competitivo (ZANINI \& MIGUELES, 2010).

Tabela 4.3: Quadro comparativo gestão do conhecimento, CRM e CKM (adaptado de Gibbert et al., 2002)

\begin{tabular}{|c|c|c|c|}
\hline & Gestão do conhecimento & CRM & CKM \\
\hline Base & $\begin{array}{l}\text { Empregados, rede de } \\
\text { empresas }\end{array}$ & Banco de dados de clientes & $\begin{array}{l}\text { Experiência do consumidor, } \\
\text { criatividade e (in)satisfação } \\
\text { com produtos e serviços }\end{array}$ \\
\hline Axiomas & $\begin{array}{llr}\text { Se nós } & & \text { apenas } \\
\text { soubéssemos } & \text { o } & \text { que } \\
\text { sabemos... } & & \end{array}$ & $\begin{array}{l}\text { Retenção é mais barata que } \\
\text { aquisição }\end{array}$ & $\begin{array}{l}\text { Se nós apenas soubéssemos o } \\
\text { que nosso cliente sabe... }\end{array}$ \\
\hline Racional & $\begin{array}{lr}\text { Desbloquear e } & \text { integrar } \\
\text { conhecimento } & \text { dos } \\
\text { funcionários } & \text { sobre } \\
\text { consumidores, processos } \\
\text { de vendas e Pesquisa e } \\
\text { Desenvolvimento }\end{array}$ & $\begin{array}{l}\text { Minerar dados sobre } \\
\text { consumidores no banco de } \\
\text { dados da empresa }\end{array}$ & \begin{tabular}{lrr} 
Ganhar & \multicolumn{2}{r}{ conhecimento } \\
diretamente através & dos \\
consumidores, assim & como \\
dividir e expandir & esse \\
conhecimento & &
\end{tabular} \\
\hline Objetivos & $\begin{array}{l}\text { Ganhos de eficiência, } \\
\text { redução de custos, e } \\
\text { evitar reinventar a roda }\end{array}$ & $\begin{array}{l}\text { Cultivo dos consumidores, } \\
\text { mantendo a base de } \\
\text { consumidores da empresa }\end{array}$ & $\begin{array}{l}\text { Colaboração com os } \\
\text { consumidores para criação de } \\
\text { valor conjunta }\end{array}$ \\
\hline Métricas & $\begin{array}{l}\text { Performance } \\
\text { orçamento }\end{array}$ & $\begin{array}{l}\text { Satisfação do consumidor e } \\
\text { lealdade }\end{array}$ & \begin{tabular}{ll} 
Vantagem & \multicolumn{2}{c}{ competitiva } \\
baseada em & inovação e \\
crescimento, & contribuindo \\
para o & sucesso do \\
consumidor & \\
\end{tabular} \\
\hline Benefícios & $\begin{array}{l}\text { Satisfação } \\
\text { consumidor }\end{array}$ & Retenção do consumidor & $\begin{array}{lcc}\text { Sucesso } & \text { do } & \text { consumidor, } \\
\text { inovação } & \text { e } & \text { aprendizado } \\
\text { organizacional } & \end{array}$ \\
\hline $\begin{array}{l}\text { Incentivos } \\
\text { para }\end{array}$ & Empregados & Consumidores & Consumidores \\
\hline $\begin{array}{l}\text { Papel do } \\
\text { consumidor }\end{array}$ & $\begin{array}{l}\text { Passivo, recebedor do } \\
\text { produto }\end{array}$ & $\begin{array}{l}\text { Cativo, ligado aos produtos } \\
\text { e serviços por esquemas de } \\
\text { lealdade }\end{array}$ & $\begin{array}{l}\text { Ativo, sócio no processo de } \\
\text { criação de valor }\end{array}$ \\
\hline $\begin{array}{l}\text { Papel } \\
\text { corporativo }\end{array}$ & $\begin{array}{l}\text { Encorajar os empregados } \\
\text { a dividir os } \\
\text { conhecimentos com seus } \\
\text { colegas }\end{array}$ & \begin{tabular}{llr} 
Construir & \multicolumn{2}{r}{ relacionamentos } \\
duradouros & com & seus \\
consumidores & &
\end{tabular} & $\begin{array}{l}\text { Emancipar consumidores de } \\
\text { recebedores para co- } \\
\text { produtores ativos de valor }\end{array}$ \\
\hline
\end{tabular}

\subsubsection{Retorno de investimentos em comunicação}

Powell (2002) cita que o cálculo do retorno sobre o investimento de marketing pode facilitar as seguintes atividades relacionadas aos programas de marketing: conceituação dos investimentos; planejamento e elaboração do orçamento; comunicação; priorização; aprovação dos orçamentos; execução e gestão; e monitoramento.

Segundo Yanaze et al. (2010), muitas empresas classificam os gastos em comunicação como despesas por não possuírem um modelo que explique os 
ganhos futuros trazidos por esses gastos, impedindo que os mesmos sejam classificados como investimentos.

Nos estudos de caso, será apurado se as empresas conseguem estimar os benefícios futuros dos investimentos em comunicação online para que seja realizado o cálculo de retorno sobre investimento.

O retorno sobre o investimento de marketing é definido como o faturamento (ou margem) gerado por um programa de marketing dividido pelo custo desse programa dentro de um determinado nível de risco. Embora a utilização do faturamento no cálculo possa ser discutível, para Powell (2002), ele pode ser usado como um indício de geração de margem.

De acordo com Lenskold (2003), o retorno sobre investimento em comunicação pode ser calculado da seguinte forma:

1 Consolida-se o investimento em marketing (I);

2 Consolida-se também o faturamento gerado por esse retorno em marketing $(\mathrm{F})$;

3 Debita-se do faturamento $(F)$ os custos de produção $(C)$, obtendo-se na margem de lucro $(\mathrm{M})$;

4 Debita-se dessa margem (M) o investimento (I) e como resultado, tem-se o Retorno da comunicação (R).

Para Lenskold (2003), apenas o retorno sobre investimento prove um quadro completo dos lucros incrementais e dos investimentos e está alinhado com os propósitos primários da organização. E quando esse acompanhamento do ROI é acompanhado da automação do marketing, a contribuição para a organização é ainda maior (LENSKOLD, 2012), como se pretende verificar nos estudos casos de aplicação de Digital Analytics.

No entanto, Yanaze et al. (2010) alertam que o retorno não pode ser baseado apenas em moedas financeiras, devendo ser incluídas moedas não financeiras como aumento do conhecimento da marca e reforço dos atributos da marca entre os consumidores. De maneira análoga, o retorno deve ser baseado na soma total dos esforços materiais e imateriais, financeiros e não financeiros. Entende-se que essa perspectiva permite o aperfeiçoamento das métricas e contribuições para estratégia, em contraponto de considerar o retorno sobre investimento apenas como fruto de uma equação. 


\section{Metodologia}

\subsection{Objetivos e questões da pesquisa}

A presente pesquisa tem como objetivo entender como as empresas utilizam o conceito de DA e elencar fatores críticos para que elas possam obter máximo proveito de uma implantação de DA. Análise dos casos e contribuição à teoria.

A pesquisa foi desdobrada em objetivos específicos para facilitar seu planejamento, melhorar a visibilidade do resultado final e permitir que as etapas sejam controladas aumentando as chances de sucesso da empreitada.

i. Num primeiro momento, pretende-se identificar os constructos através de levantamento bibliográfico. A partir desses constructos, será montado um framework de DA a ser utilizado na pesquisa de campo e na análise dos estudos de caso.

ii. A aplicação do framework será analisada em diversas empresas brasileiras para se entender como e porque DA é utilizado nas organizações.

iii. A análise sobre os dados empíricos avaliará o alinhamento estratégico de DA e sua eficácia para os negócios.

iv. Após esse entendimento mais profundo sobre a aplicação dos conceitos de DA nas empresas, serão identificados os principais elementos de sucesso na implantação de DA.

\subsection{Abordagem metodológica}

A abordagem de estudo de caso procura aprofundar um conhecimento sobre um dado problema que ainda não está bem definido através de um ou mais objetos (casos) (MIGUEL, 2007). Os estudos de caso tendem a esclarecer 0 motivo pelo qual uma decisão ou um conjunto de decisões foram tomados, como as ações foram implementadas e quais resultados foram alcançados (YIN, 2001).

Essa abordagem possui forte aderência ao objetivo da pesquisa de aumentar o conhecimento sobre a aplicação de DA e seu alinhamento estratégico nas 
empresas brasileiras; e parece ser a melhor abordagem para elucidar os questionamentos desse estudo:

Q1. Como e porque as empresas aplicam os conceitos de DA em seus negócios?

Q2. Como é feito o alinhamento estratégico entre DA e os negócios?

Q3. De que forma DA pode aumentar a criação de valor estratégico?

Além da aderência às questões que serão analisadas, outra vantagem da abordagem de estudo de caso é que pode ela pode ser apoiada em múltiplas fontes de evidência que permitem a técnica de triangulação, onde haverá iteração entre as diversas fontes para sustentar os constructos, proposições ou hipóteses, visando analisar a convergências das fontes de evidência (MIGUEL, 2007).

\subsection{Planejamento da pesquisa}

A condução metodológica dos estudos de caso representa um problema relevante para a Engenharia de Produção, por esse motivo, deve ser realizado um planejamento cuidadoso da pesquisa, que deve incluir as seguintes etapas (MIGUEL, 2007) (figura 5.1):

- Definição da estrutura conceitual-teórica

- Planejamento dos casos

- Condução do teste piloto

- Coleta dos dados

- Análise dos dados

- Geração do relatório 


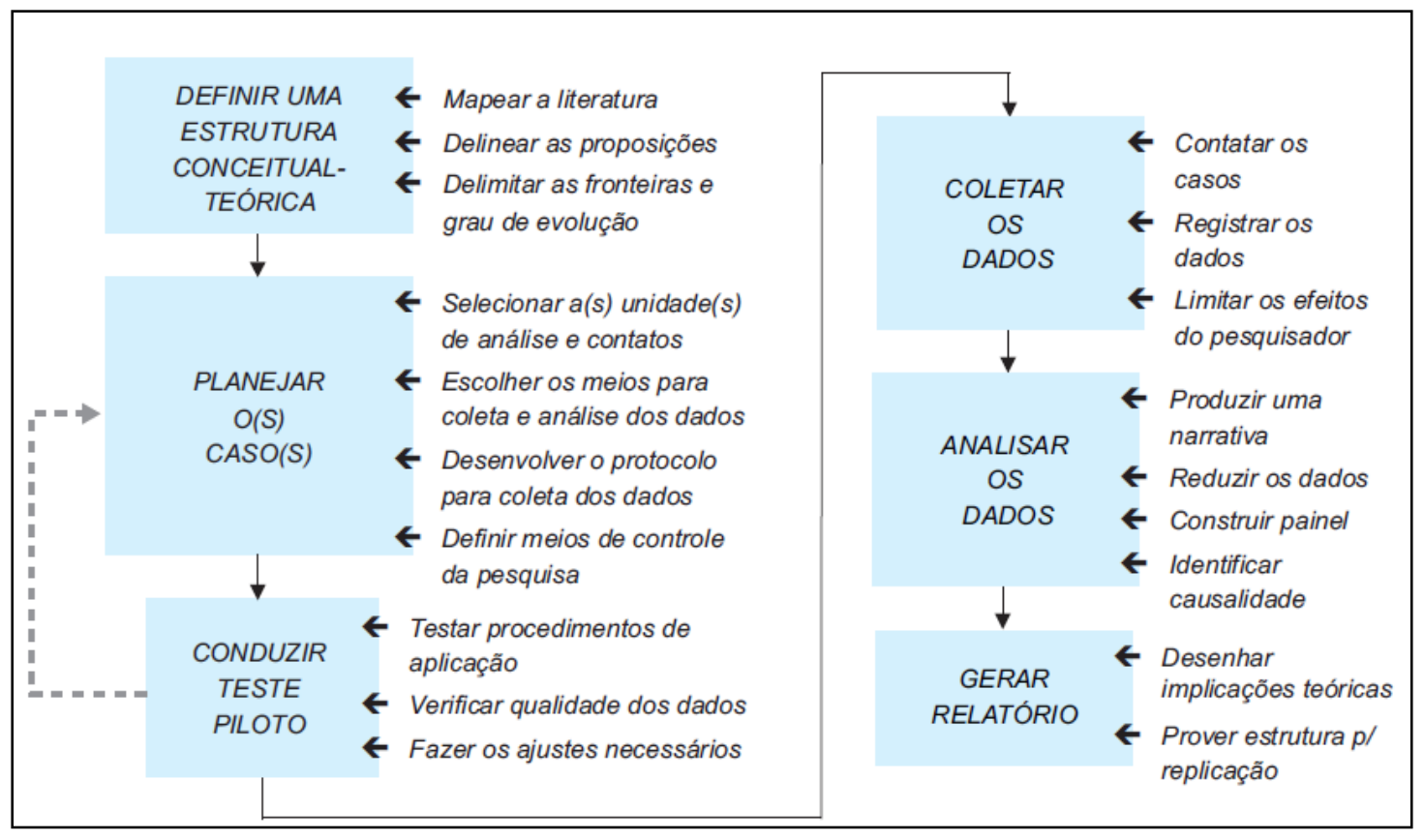

Figura 5.1: Condução do estudo de caso (MIGUEL, 2007)

\subsection{Definição da estrutura conceitual-teórica}

A pesquisa bibliográfica foi baseada nas perguntas da pesquisa e geraram três constructos: Capacidade analítica, contribuições da internet para a estratégia e gestão de negócios. Cada um desses constructos foi aprofundado através de conceituações e premissas que serão relevantes para definição das proposições da pesquisa (figura 5.2).

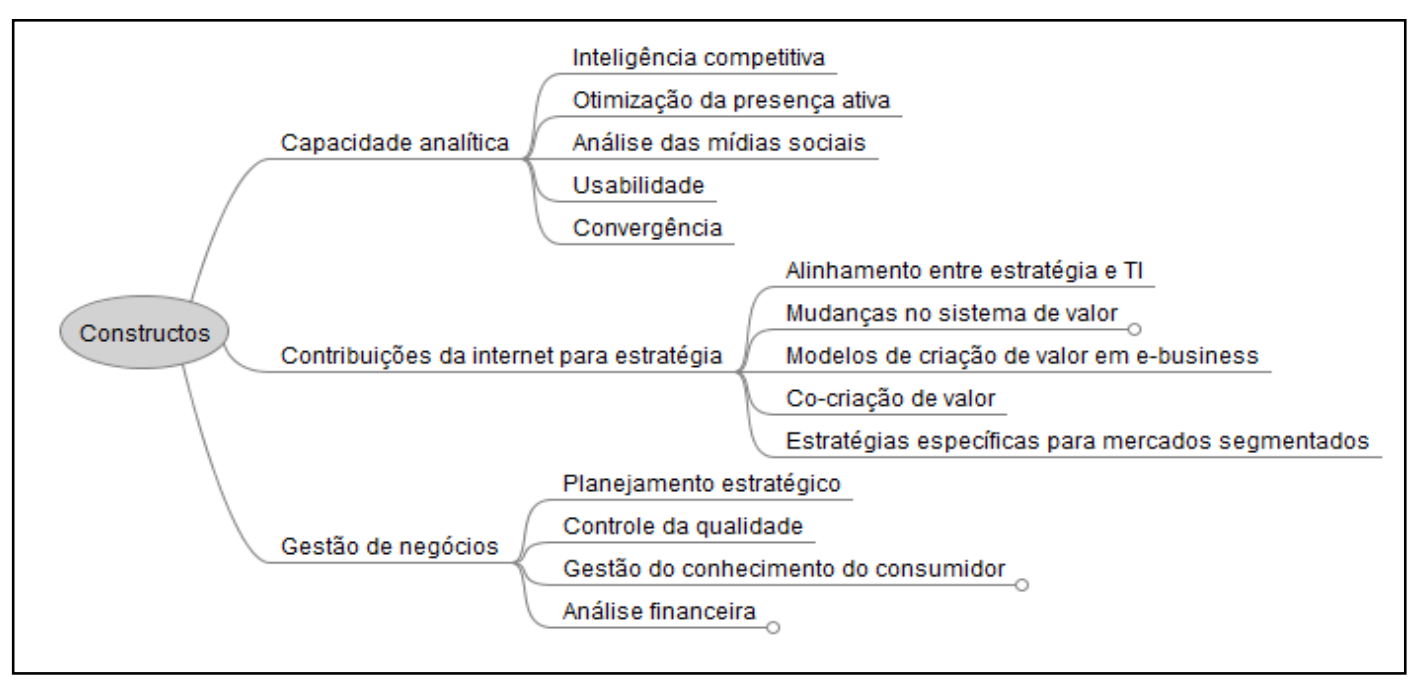

Figura 5.2: Constructos e variáveis da pesquisa

O constructo de capacidade analítica é relevante para análise da Q1: "Como e porque as empresas aplicam os conceitos de DA em seus negócios?". A partir 
do conceito de Kaushik (2009) foram identificadas as seguintes premissas sobre DA localizadas nas referências bibliográficas:

- Inteligência competitiva (TARAPANOFF, 2004; WAA, 2008) - As informações de pesquisas de mercado sobre audiência dos internautas e a visitação aos sites concorrentes são relevantes para a inteligência competitiva, pois permitem que num tempo muito curto atualize-se um benchmark sobre a empresa e seus concorrentes, sem a necessidade de dispendiosas pesquisas de campo.

- Otimização de presença ativa (FOX, 2010; SCOTT, 2011, ENGE et al., 2009) - A Internet permite que os esforços de comunicação sejam mesurados e a eficiência da campanha seja melhorada em tempo real.

- Análise das mídias sociais (STERN, 2010; CUI e GUO, 2009; LIMA et al., 2005; KLOUT, 2012) - As análises de posts nas redes sociais são um termômetro para avaliar a influência das marcas, os sentimentos do consumidor e suas possíveis intenções de compra. Essa análise também permite mensurar hábitos e desejos importantes para pesquisa e desenvolvimento de novos produtos e serviços e até mesmo co-criar esses produtos e serviços com os consumidores.

- Usabilidade (KAUSHIK, 2009; CUTRONI, 2010) - As análises referentes a usabilidade fazem com que o consumidor seja o centro do processo de melhoria contínua do site que visa, fundamentalmente, melhorar a conversão de visitas em negócios.

- Convergência (BUGHIN et al, 2008; SHANKAR \& YADAV, 2010) - A integração entre dados de ações online e offline executadas em diversos canais pode melhorar os resultados de empreendimentos corporativos como campanhas e novos produtos.

O constructo Contribuições da Internet para a Estratégia auxiliará na investigação da Q2 "Como é feito o alinhamento estratégico entre DA e os negócios?". As premissas a esse constructo são as seguintes:

- Alinhamento entre estratégia de negócios (MINTZBERG \& LAMPEL, 1999) e tecnologia (ROCKART, 1979; PORTER \& MILLAR, 1985; PORTER, 2001; LAURINDO, 2008), grau de maturidade do alinhamento (LUFTMAN, 2003) e a forma como ocorre (HENDERSON \& 
VENKATRAMAN, 1993; BUCHANAN, J. R.; LINOWES,1980) - Para que o uso da tecnologia seja eficaz, ela deve estar vinculada aos fatores críticos de sucesso da empresa. O alinhamento entre estratégia e TI reflete-se nas ligações entre as atividades dentro e fora da cadeia de valor, podendo seguir quatro perspectivas: execução da estratégia, transformação tecnológica, potencial competitivo e nível de serviço. Esse alinhamento pode ser classificado pela maneira como a estratégia de negócios é formulada, o grau de maturidade desse alinhamento e a descentralização da operação e o controle da TI/DA.

- Integração do sistema de valor (PORTER, 2001) - desde que seu uso seja devidamente alinhado com a estratégia corporativa, a Internet pode ser uma plataforma de integração do sistema de valor.

- A cadeia de valor virtual (CHANDRASHEKAR \& SCHARY, 1999; RAYPORT \& SVIOKLA, 1995) e as implicações da virtualidade nos negócios (ANGHERN, 1997) na organização (VENKATRAMAN \& HENDERSON, 1998) e no desenvolvimento de seus produtos e serviços (MATTOS \& LAURINDO, 2008) - a integração das atividades proporcionada pela Internet permite arranjos mais flexíveis da cadeia de valor que podem ser definidos de acordo com a demanda, esses novos arranjos definiram um novo campo para a competição entre as empresas que é o marketspace, onde as empresas competem vitualmente.

- As redes de valor entre as empresas (BOVET \& MARTHA, 2001) - A mudança tecnológica torna a própria cadeia de valor inadequada para os modelos de negócios para e-business que, normalmente, operam numa plataforma colaborativa denominada rede de valor.

- Os modelos de criação de valor específicos para o e-business (AMIT \& ZOTT, 2001) - As transformações do ambiente competitivo levam a necessidade das empresas terem um modelo de negócios específico para as operações de e-business.

- A co-criação de valor (PRAHALAD \& RAMASWAMY, 2000, 2004; PRAHALAD \& KRISHNA, 2008; GIBBERT 2002; TAPSCOTT \& 
WILLIAMS, 2007) - A Internet permite o desenvolvimento de novos produtos e serviços em conjunto com os consumidores.

- Adoção de estratégias específicas para mercados segmentados (BRYNJOLFSSON, 2003; ANDERSON, 2006; KIM, 2005) - A Internet democratiza os meios de produção e de distribuição e, ao mesmo tempo, disponibiliza uma melhor conexão entre a oferta e a demanda. Essas transformações permitem o desenvolvimento de mercados mais segmentado, cauda longa, e habilitam novas formas de competição entre as empresas.

O último constructo, Gestão de Negócios, endereça a Q3: "De que forma DA pode aumentar a criação de valor estratégico?". Esse constructo fornece elementos para o desenvolvimento de um método que integre as contribuições de DA com a estratégia de negócios. Ele é baseado nas seguintes premissas:

- O planejamento estratégico (KAPLAN \& NORTON, 1997) - esse planejamento é essencial para que os esforços da empresa tenha direcionadores claros a fim de se obter os resultados nas dimensões financeira, mercadológica, processual e de inovação e crescimento. 0 alinhamento dos indicadores de DA com o planejamento estratégico da empresa pode impulsionar os negócios.

- A gestão do conhecimento gerado pelo consumidor (GIBBERT et al., 2002) - O conhecimento gerado pelo consumidor nas mídias sociais e no próprio site passa a ser fonte de valor estratégico, pois a empresa pode se impulsionar nesse conhecimento para melhoria dos seus processos e para inovação.

- Controle da qualidade (DAVIS et al., 2001) - A aplicação das ferramentas da qualidade permite que a empresa estabeleça um ciclo de melhoria contínua de seus processos de forma a atingir a excelência em seu mercado. A aplicação das ferramentas da qualidade em DA pode melhorar a consistência das análises e contribuir para melhoria contínua da presença online.

- Análise financeira (YANAZE et al., 2010) - A mensuração e melhoria contínua do investimento em comunicação online é chave para 
justificativa financeira das ações na web. DA pode contribuir para análise dos retornos de investimentos em comunicação.

Estabelecidos os constructos, as variáveis e as premissas (tabela 5.1), formase a base teórica para as proposições da pesquisa (tabela 5.2). Foram elaboradas três proposições:

P1 - Empresas que utilizam o potencial de DA:

- analisam dados qualitativos e quantitativos da experiência online de seus clientes/consumidores;

- realizam benchmarks de seus concorrentes utilizando dados de pesquisas de mercado, visita a sites e análise dos comentários de clientes/consumidores nas redes sociais;

- melhoram continuamente sua presença online assim como, seus produtos e serviços, através das recomendações advindas de DA.

P2 - DA pode gerar contribuições para a estratégia corporativa.

P3 - É possível melhorar o resultado das implantações de DA através de um método que incorpore elementos da gestão de negócios.

\subsection{Planejamento dos casos}

\subsubsection{Pesquisa exploratória}

Os estudos de caso serão precedidos de pesquisa exploratória para aprofundar o entendimento sobre o tema DA e sua aplicação nas empresas. Essa pesquisa exploratória foi composta de pesquisa documental, survey e pesquisa qualitativa.

A pesquisa documental foi realizada com base em relatórios da consultoria WA (2009, 2010), que fornecem dados sobre a evolução da penetração das ferramentas de DA e em consultas aos documentos da Digital Analytics Association. 
Tabela 5.1: Relações entre constructos, variáveis e premissas

\begin{tabular}{|c|c|c|}
\hline Constructos & Variáveis & Premissas \\
\hline \multirow{5}{*}{$\begin{array}{l}\text { Capacidade } \\
\text { analítica }\end{array}$} & $\begin{array}{l}\text { Inteligência } \\
\text { competitiva }\end{array}$ & $\begin{array}{l}\text { A inteligência competitiva é incrementada com informações sobre a audiência e } \\
\text { as funcionalidades dos sites concorrentes (TARAPANOFF, 2004; WAA, 2008; } \\
\text { YANAZE, 2011) }\end{array}$ \\
\hline & $\begin{array}{l}\text { Otimização de } \\
\text { presença ativa }\end{array}$ & $\begin{array}{l}\text { As campanhas online são otimizadas através do acompanhamento de seus } \\
\text { indicadores de eficiência e eficácia (FOX, 2010; SCOTT, 2011; ENGE et al., } \\
\text { 2009; MAYAR \& RAMSEY, 2011; FARRIS et al., 2007) }\end{array}$ \\
\hline & Mídias sociais & $\begin{array}{l}\text { A influência das marcas, os sentimentos do consumidor e a intenção de compra } \\
\text { podem ser mensurados nas mídias sociais (STERN, 2010; CUI e GUO, 2009; } \\
\text { LIMA et al., 2005; KLOUT, 2012; SPONDER, 2012; KAUSHIK, 2010) }\end{array}$ \\
\hline & Usabilidade & $\begin{array}{l}\text { Analisando a usabilidade de seu site, as empresas propõem a melhoria contínua } \\
\text { da conversão de visitas em ações (KAUSHIK, 2009; CUTRONI, 2010) }\end{array}$ \\
\hline & Convergência & $\begin{array}{l}\text { A integração entre as informações dos diversos canais de contato com o } \\
\text { consumidor, sejam online ou offline, são relevantes para os negócios (BUGHIN et } \\
\text { al, 2008; SHANKAR \& YADAV, 2010) }\end{array}$ \\
\hline \multirow{5}{*}{$\begin{array}{l}\text { Contribuições } \\
\text { da Internet } \\
\text { para } \\
\text { Estratégia }\end{array}$} & $\begin{array}{c}\text { Alinhamento } \\
\text { entre estratégia e } \\
\text { TI }\end{array}$ & $\begin{array}{l}\text { O alinhamento entre TI e estratégia é relevante para a eficácia dos investimentos } \\
\text { em TI, sendo relevante também para as implantações de DA (ROCKART, 1979; } \\
\text { PORTER \& MILLAR, 1985, PORTER, 2001; HENDERSON \& VENKATRAMAN, } \\
\text { 1993; LAURINDO, 2008). Esse alinhamento pode ser classificado pela maneira } \\
\text { como a estratégia de negócios é formulada (MINTZBERG \& LAMPEL, 1999), o } \\
\text { grau de maturidade desse alinhamento (LUFTMAN, 2003) e a descentralização } \\
\text { da operação e o controle da TI/DA (BUCHANAN \& LINOWES,1980) }\end{array}$ \\
\hline & $\begin{array}{l}\text { Mudanças no } \\
\text { sistema de valor }\end{array}$ & $\begin{array}{l}\text { A Internet transforma o sistema de valor através de maior integração (PORTER, } \\
\text { 2001); as implicações da virtualidade nos negócios (ANGHERN, 1997); a adição } \\
\text { de elementos das cadeias de valor virtuais (CHANDRASHEKAR \& SCHARY, } \\
\text { 1999; RAYPORT \& SVIOKLA, 1995) e/ou formação de redes de valor entre os } \\
\text { agentes desse sistema (BOVET \& MARTHA, 2001). A virtualidade pode ocorrer } \\
\text { toda a organização (VENKATRAMAN \& HENDERSON, 1998) ou, } \\
\text { especificamente, no desenvolvimento de seus produtos e serviços (MATTOS \& } \\
\text { LAURINDO, 2008) }\end{array}$ \\
\hline & $\begin{array}{l}\text { Modelos de } \\
\text { criação de valor } \\
\text { em e-business }\end{array}$ & $\begin{array}{l}\text { Os modelos de negócios específicos para o e-business promovem eficiência, } \\
\text { inovação, fidelização e complementaridades (AMIT \& ZOTT, 2001) }\end{array}$ \\
\hline & $\begin{array}{l}\text { Co-criação de } \\
\text { valor }\end{array}$ & $\begin{array}{l}\text { A internet possibilita a co-criação de valor entre a empresa e seus } \\
\text { clientes/consumidores (PRAHALAD \& RAMASWAMY, 2000, 2004; PRAHALAD } \\
\text { \& KRISHNA, 2008; SHAMMA, 2007; TAPSCOTT \& WILLIAMS, 2007). }\end{array}$ \\
\hline & $\begin{array}{l}\text { Estratégias para } \\
\text { mercados } \\
\text { segmentados }\end{array}$ & $\begin{array}{l}\text { A Internet possibilitou a criação de mercados cada vez mais segmentados } \\
\text { (BRYNJOLFSSON, 2003; ANDERSON, 2006), onde a competição é baseada em } \\
\text { estratégias específicas (KIM \& MAUBORGNE, 2005) }\end{array}$ \\
\hline \multirow{4}{*}{$\begin{array}{l}\text { Gestão de } \\
\text { negócios }\end{array}$} & $\begin{array}{l}\text { Planejamento } \\
\text { estratégico }\end{array}$ & $\begin{array}{l}\text { O alinhamento dos indicadores de DA com o planejamento estratégico da } \\
\text { empresa é crítico para a eficácia nos negócios (ROCKART, 1979; KAPLAN \& } \\
\text { NORTON, 1997; YANAZE, 2011). }\end{array}$ \\
\hline & $\begin{array}{l}\text { Controle da } \\
\text { qualidade }\end{array}$ & $\begin{array}{l}\text { A aplicação das ferramentas da qualidade em DA pode melhorar a consistência } \\
\text { das análises e contribui para melhoria contínua da presença online. DA também } \\
\text { pode contribuir na coleta da voz do cliente para o QFD (DAVIS et al.,2001). }\end{array}$ \\
\hline & $\begin{array}{l}\text { Gestão do } \\
\text { conhecimento do } \\
\text { consumidor }\end{array}$ & $\begin{array}{l}\text { A gestão do conhecimento do consumidor gerado por DA permite que a empresa } \\
\text { promova a inovação e a melhoria de seus processos (GIBBERT et al., 2002; } \\
\text { ZANINI \& MIGUELES, 2010; FOX, 2010). }\end{array}$ \\
\hline & Análise financeira & $\begin{array}{l}\text { DA pode contribuir para mensuração dos retornos de investimentos em } \\
\text { comunicação online (YANAZE et al., 2010; LENSKOLD, 2003; POWELL, 2002) }\end{array}$ \\
\hline
\end{tabular}


Tabela 5.2: Proposições e referências bibliográficas

\begin{tabular}{|c|c|c|}
\hline \multicolumn{2}{|r|}{ Proposição } & Referências \\
\hline P1 & $\begin{array}{l}\text { Empresas que utilizam o potencial de DA: } \\
\text { - analisam dados qualitativos e } \\
\text { quantitativos da experiência online de } \\
\text { seus clientes/consumidores; } \\
\text { - realizam benchmarks de seus } \\
\text { concorrentes utilizando dados de } \\
\text { pesquisas de mercado, visita a sites e } \\
\text { análise dos comentários de } \\
\text { clientes/consumidores nas redes sociais; } \\
\text { - melhoram continuamente sua presença } \\
\text { online, assim como, seus produtos e } \\
\text { serviços, através das recomendações } \\
\text { advindas de DA. }\end{array}$ & $\begin{array}{l}\text { KAUSHIK, 2009; TARAPANOFF, 2004; WAA, 2008; } \\
\text { YANAZE, 2011; FOX, 2010; SCOTT, 2011; ENGE et } \\
\text { al., 2009; MAYAR \& RAMSEY, 2011; FARRIS et al., } \\
\text { 2007; STERN, 2010; CUI e GUO, 2009; LIMA et al., } \\
\text { 2005; KLOUT, 2012; SPONDER, 2012; KAUSHIK, } \\
\text { 2010; PRAHALAD \& RAMASWAMY, 2000, 2004; } \\
\text { PRAHALAD \& KRISHNA, 2008; SHAMMA, 2007; } \\
\text { TAPSCOTT \& WILLIAMS, } 2007\end{array}$ \\
\hline P2 & $\begin{array}{l}\text { DA pode gerar contribuições para a } \\
\text { estratégia corporativa }\end{array}$ & $\begin{array}{c}\text { ROCKART, 1979; PORTER \& MILLAR, 1985, } \\
\text { PORTER, 2001; LAURINDO, 2008; MINTZBERG \& } \\
\text { LAMPEL, 1999; HENDERSON \& VENKATRAMAN, } \\
\text { 1993; LUFTMAN, 2003; BUCHANAN \& } \\
\text { LINOWES,1980; ANGHERN, 1997; } \\
\text { CHANDRASHEKAR \& SCHARY, 1999; RAYPORT \& } \\
\text { SVIOKLA, 1995; BOVET \& MARTHA, 2001; } \\
\text { VENKATRAMAN \& HENDERSON, 1998; MATTOS \& } \\
\text { LAURINDO, 2008; AMIT \& ZOTT, 2001; } \\
\text { PRAHALAD \& RAMASWAMY, 2000, 2004; } \\
\text { PRAHALAD \& KRISHNA, 2008; SHAMMA, 2007; } \\
\text { TAPSCOTT \& WILLIAMS, 2007; BRYNJOLFSSON, } \\
\text { 2003; ANDERSON, 2006; KIM \& MAUBORGNE, } 2005\end{array}$ \\
\hline P3 & $\begin{array}{l}\text { É possível melhorar o resultado das } \\
\text { implantações de DA através de um } \\
\text { método que incorpore elementos da } \\
\text { gestão de negócios }\end{array}$ & $\begin{array}{l}\text { KAPLAN \& NORTON, } 1997 \\
\text { BUGHIN et al, 2008; YANAZE, 2011; SHANKAR \& } \\
\text { YADAV, 2010; DAVIS et al., 2001; GIBBERT et al., } \\
\text { 2002; ZANINI \& MIGUELES, 2010; FOX. 2010; } \\
\text { POWELL, 2002; LENSKOLD, 2003; YANAZE et al., } \\
2010\end{array}$ \\
\hline
\end{tabular}

A survey foi aplicada entre 76 executivos de áreas de negócios de empresas de diversos portes. Considerando-se uma confiabilidade de $95 \%$, foi calculada uma margem de erro de $11 \%$, considerada aceitável para um estudo exploratório. O objetivo dessa survey foi entender se a Internet apoia o negócio dessas empresas na Internet, se as empresas empregavam DA e que práticas de DA são adotadas. O pesquisado foi convidado a classificar diversas 
afirmações de acordo com uma escala Likert, onde o item significava "discordo plenamente" e o item 5 "concordo plenamente".

O primeiro bloco de afirmações tratava do e-business da empresa e possuía as seguintes afirmações:

1. Possui site com informações institucionais;

2. Usa troca eletrônica de dados (EDI /B2B);

3. Usou no passado troca eletrônica de dados (EDI/B2B);

4. O comércio eletrônico possibilitou o acesso a novos mercados para vendas;

5. O comércio eletrônico possibilitou o acesso a novos mercados para compras;

6. Vende freqüentemente aos consumidores finais através do comércio eletrônico;

7. Vende freqüentemente a outras empresas através do comércio eletrônico;

8. Usa freqüentemente comércio eletrônico para comprar de outras empresas;

9. Presta serviços através da Internet para seus clientes;

10. Os clientes usam frequentemente os serviços disponíveis no site.

Outro bloco de afirmações discorria sobre o uso de DA pela empresa:

1. Capta dados de concorrentes na Internet para realização de benchmark?

2. Capta dados de não clientes (prospects) na Internet para geração de negócios?

3. Analisa o comportamento dos clientes que navegam, transacionam ou usam serviços no site da empresa (web analytics)?

4. Tem procedimentos sistemáticos para analisar os dados coletados sobre os clientes no site da empresa?

5. Possui ferramentas específicas (web analytics) para coleta e análise dessas informações

6. Sua empresa analisa o que seus clientes dizem nas mídias sociais (blogs, orkut, facebook, fóruns)? 
7. Tem procedimentos sistemáticos para analisar os dados coletados sobre os clientes nas redes sociais?

Análise dos assuntos mais freqüentes em fóruns com profissionais que utilizam e implantam práticas de DA para entender quais devem ser os fatores críticos numa implantação de DA.

\subsubsection{Seleção dos casos}

A metodologia de estudo de caso permite a análise de apenas um caso ou dce múltiplos casos. Normalmente, se aplica apenas um estudo de caso quando se pretende uma análise bastante aprofunda com perspectiva longitudinal. Embora haja vantagens nessa abordagem, ela prejudica uma possível generalização das conclusões do estudo (YIN, 2001). Como se pretende estudar um panorama mais abrangente da aplicação de DA nas empresas brasileiras, a análise será baseada em estudo de múltiplos.

A partir de uma lista de empresas cuja análise seria relevante para os estudos de caso, sete empresas consentiram em colaborar com a pesquisa, formando um quadro bem variado das empresas brasileiras, seja com relação ao segmento, ao setor ou ao mercado (tabela 5.3). As empresas cobriram diversos segmentos da economia, embora não tenhamos conseguido autorização para estudar indústrias interessantes como a bancária e de telecomunicações.

Tabela 5.3: Casos da pesquisa

\begin{tabular}{|l|l|l|c|}
\hline \multirow{2}{*}{ Caso } & \multicolumn{3}{|c|}{ Características da empresa } \\
\cline { 2 - 4 } & Segmento & \multicolumn{1}{|c|}{ Setor } & Mercado \\
\hline A & Software & Serviços & B2B \\
\hline B & Automobilístico & Manufatura & B2C \\
\hline C & Vestuário & Manufatura & B2C \\
\hline D & Bebidas & Manufatura & B2C \\
\hline E & Editora & Serviços & B2B \\
\hline F & E-commerce & Serviços & B2C \\
\hline G & Fonográfico & Serviços & B2C \\
\hline
\end{tabular}

A seleção das empresas ocorreu de acordo com os seguintes critérios prédeterminados (YIN, 2001):

- Relevância econômica da empresa e da indústria na qual está inserida, a empresa precisa atuar numa indústria que seja representativa em 
termos de PIB nacional e ao mesmo tempo ser um competidor de destaque em seu setor.

- Deve haver casos de empresas de manufatura e de serviços.

- As empresas devem possuir presença online que seja relevante para construir um relacionamento com o consumidor com uma audiência mínima de 10.000 visitantes em se tratando de sites voltados para o consumidor final (B2C).

- As empresas devem realizar análises de DA tendo como foco pelo menos um dos temas elencados no constructo de DA: inteligência competitiva, campanhas online, usabilidade e/ou mídias sociais.

O caso A é de um desenvolvedor de software para empresas de comércio exterior, que por atuar em mercado B2B possui uma audiência restrita, mas ainda sim importante para seu ramo de atuação. No site dessa empresa, são oferecidos serviços para seus clientes e informações para prospects que se interessaram por seus produtos. As análises de DA abrangem: inteligência competitiva, otimização de campanhas de links patrocinados e análise de usabilidade.

O caso B é de uma montadora, que também possui audiência expressiva e oferece diversas funcionalidades em seu site, sendo que a mais importante delas é o "Monte seu carro", onde o consumidor pode simular o modelo de sua preferência de acordo com uma configuração personalizada. Essa empresa utiliza DA para: monitorar seus concorrentes, otimizar um alto investimento em mídia online e verificar o grau de influência nas mídias sociais.

O caso C refere-se a uma empresa do segmento de vestuário, cujo site possui mais de 100 mil visitantes por mês. Essa empresa possui uma marca conhecida globalmente e utiliza DA para fornecer subsídios para inteligência competitiva, verificar a usabilidade de seu site que está disponível em diversos idiomas e entender como o usuário utiliza seus produtos e qual a adesão à marca nas mídias sociais.

O caso $D$ é de uma empresa do ramo de bebidas não alcoólicas, seu site oferece informações sobre seus produtos e receitas, assim como jogos e atividades de entretenimento. A audiência é expressiva e as análises realizadas cobrem todos os temas identificados no constructo de DA. 
O caso E é de uma editora que vende sistemas de ensino para escolas, o site dessa escola estabelece contato com escolas, professores e alunos, para divulgação do material didático e prestação de serviços. As análises realizadas abrangem estudos de usabilidade para mensuração dos conteúdos mais acessados.

$O$ caso $F$ refere-se a um varejo de artigos esportivos que possui alto investimento em mídia online e procura rentabilizar seus investimentos através de ofertas segmentadas de acordo com o perfil do público.

$O$ caso $G$ é de um grupo de música que utilizou uma estratégia de divulgação através das mídias sociais, incluindo distribuição de suas músicas de forma gratuita. Hoje, esse grupo realiza shows por todo o Brasil e consegue obter lucro com suas atividades.

\subsubsection{Protocolo}

A forma como os dados serão coletados e analisados seguirão um protocolo. Basicamente, um protocolo deve conter (MIGUEL, 2007):

- Procedimentos e regras gerais da pesquisa

- Indicação das origens das fontes de informação

- As variáveis de controle da pesquisa

- As questões que a serem aprofundadas

O contato inicial para solicitação de adesão à pesquisa foi realizado com a pessoa responsável pelos projetos online em cada empresa. Essas pessoas foram localizadas através de contatos pessoais, profissionais e acadêmicos.

As entrevistas foram realizadas em local e horário agendados com bastante antecedência. A pessoa-chave de cada empresa foi responsável por elaborar a lista de entrevistados e priorizar suas respectivas agendas. Os executivos selecionados foram prioritariamente da área de marketing e tecnologia e foram escolhidos de acordo o nível de responsabilidade sobre os projetos web da empresa. Devido ao enfoque estratégico da pesquisa, as áreas de negócios foram mais acessadas, sendo solicitadas entrevistas com executivos de $\mathrm{TI}$ quando houve detalhes relevantes na implementação de DA.

Apenas uma das empresas concordou em divulgar o nome, mantendo-se nos outros casos a denominação genérica Caso $A, B$ e $C$. 
Com exceção de um caso, não foram utilizados gravadores para que o executivo não se sentisse intimidado, foi necessária a anotação de tópicos durante a entrevista e, assim que possível, a consolidação dos dados em atas de reunião para evitar que fossem perdidos registros importantes como a forma que o executivo demonstrou seu raciocínio.

Os estudos de caso foram baseados em múltiplas fontes de informação para que possa ser feita a triangulação das evidências (MIGUEL, 2007). Dentre essas fontes, pode-se destacar:

- Análise da audiência do site da empresa e do mercado onde ela atua baseado em pesquisas de mercado

- Visita ao site da empresa para fichamento das funcionalidades

- Verificação da implantação de ferramenta de DA através da análise do código fonte do site

- Leitura de relatórios de DA quando os mesmos forem fornecidos pelas empresas analisadas

- Entrevista com executivos das áreas de tecnologia e negócios baseado em roteiro semi-estruturado que será detalhado a seguir

- Análise das informações publicadas por clientes/fornecedores dessas redes sociais

As entrevistas foram baseadas em roteiro semi-estruturado (YIN, 2001), ou seja, as questões elencadas no roteiro são para referência do entrevistador, podendo ser aprofundadas ou omitidas de acordo com a necessidade. As questões foram apoiadas nos três constructos da pesquisa: Digital Analytics (tabela 5.4), contribuições da internet para a estratégia (tabela 5.5) e gestão de negócios (tabela 5.6). 
Tabela 5.4: Questões do roteiro semi-estruturado relacionadas ao constructo de Capacidade Analítica

\begin{tabular}{|c|c|c|}
\hline 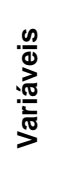 & 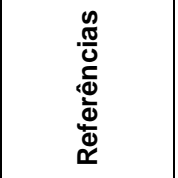 & Questões \\
\hline 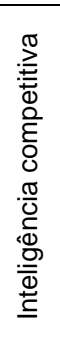 & 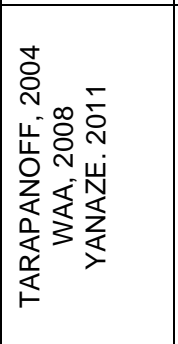 & $\begin{array}{l}\text { - Há consulta a pesquisas de mercado para comparar sua audiência na Internet com } \\
\text { - Soncorrentes e verificar o perfil do consumidor na Internet? } \\
\text { - São realizados benchmarks através de visitas aos sites dos concorrentes? } \\
\text { - É avaliada a posição do site da empresa na busca orgânica dos mecanismos de busca e } \\
\text { também nos links patrocinados? } \\
\text { - Há analisados os comentários sobre produtos e serviços disponíveis nas mídias sociais? } \\
\text { - Bases digitais do governo ou de associações de classe são usadas nos painéis de } \\
\text { mercado? }\end{array}$ \\
\hline 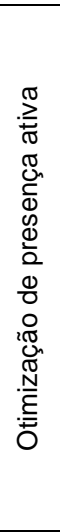 & 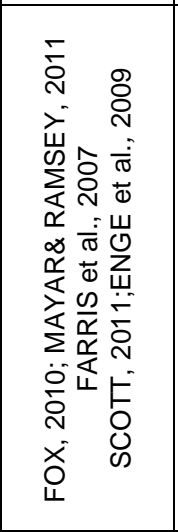 & $\begin{array}{l}\text { - É comum no seu mercado, as empresas realizarem campanhas online? Se não for, qual } \\
\text { - seria o motivo? } \\
\text { - A empresa compra links patrocinados em mecanismos de busca? } \\
\text { - A empresa realiza campanhas de mídia gráfica (banners, pop-ups, e-mails)? } \\
\text { - A empresa usa táticas de SEO para aumentar a audiência através? } \\
\qquad \quad \text { Cobertura? } \\
\circ \quad \text { Volume de impactos e frequência? } \\
\circ \quad \text { Taxa de cliques (CTR)? } \\
\circ \quad \text { Percepção de marca? } \\
\circ \quad \text { Grau de engajamento? } \\
\circ \quad \text { Taxa de ações finalizadas? } \\
\circ \quad \text { ROI? } \\
\end{array}$ \\
\hline 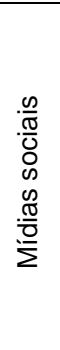 & 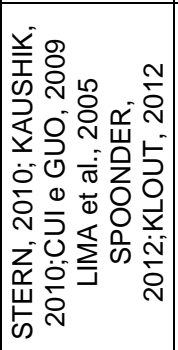 & $\begin{array}{l}\text { - No mercado em que a empresa atua, os comentários publicados nas redes sociais são } \\
\text { - } \text { - A elevantes para estratégia de comunicação das empresas? Se não, por que? } \\
\text { - Há algum procedimento regular de coleta de informações nas redes sociais? São usadas } \\
\text { - ferramentas para isso? } \\
\text { - A empresa realiza inferências sobre a influência de suas marcas em redes sociais? } \\
\text { - Os sentimentos do consumidor são monitorados nas redes socais? } \\
\text { - Foi realizado algum estudo que relacione a atividade nas redes sociais com a intenção de } \\
\text { compra? }\end{array}$ \\
\hline 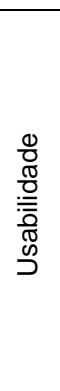 & 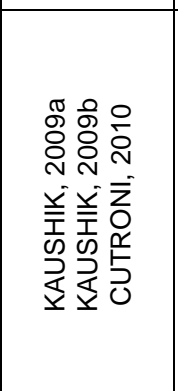 & $\begin{array}{l}\text { - A empresa possui ferramentas que permitem o tracking na navegação do usuário? Se } \\
\text { não, entender o motivo? } \\
\text { - O comportamento do usuário no site é avaliado? Com que periodicidade? } \\
\text { - Há clareza sobre quais ações o usuário deveria realizar no site? } \\
\text { Indicadores de usabilidade como bounce rate e tempo de navegação no site são } \\
\text { utilizados? } \\
\text { - Os funis de conversão são monitorados? } \\
\text { - Há melhorias contínuas na presença online para aumentar a qualidade da experiência dos } \\
\text { usuários? }\end{array}$ \\
\hline $\begin{array}{l}\frac{\pi}{0} \\
\frac{\pi}{\Phi} \\
\frac{D}{\Phi} \\
\stackrel{0}{0} \\
0 \\
0\end{array}$ & 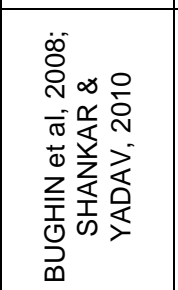 & $\begin{array}{l}\text { - Há analises cruzadas de informações de ações online e offline? } \\
\text { - Os insights gerados por DA são utilizados no planejamento de ações offline como } \\
\text { - Oesenvolvimento de campanhas ou lançamento de novos produtos? } \\
\text { - Os dados dos diversos canais como web, mobile, TV digital são consolidadas? }\end{array}$ \\
\hline
\end{tabular}


Tabela 5.5: Questões do roteiro relacionadas ao constructo de contribuições da internet para a estratégia

\begin{tabular}{|c|c|c|}
\hline 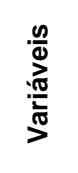 & 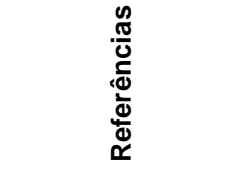 & Questões \\
\hline 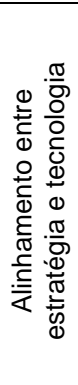 & 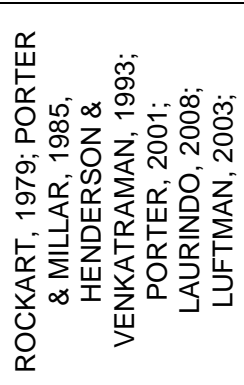 & $\begin{array}{l}\text { - Qual a escola de pensamento preponderante na formulação da estratégia? } \\
\text { - Os fatores críticos de sucesso (FCSs) da empresa foram identificados? Se não, } \\
\text { - Qur que? } \\
\text { - } \text { - Qual o modelo de alinhamento entre a estratégia de negócios e a tecnologia } \\
\text { - Cual o grau de maturidade do alinhamento entre TI e negócios? } \\
\text { TI? } \\
\text { - Qual o nível de descentralização da operação e controle de DA? }\end{array}$ \\
\hline 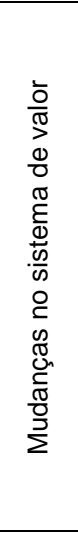 & 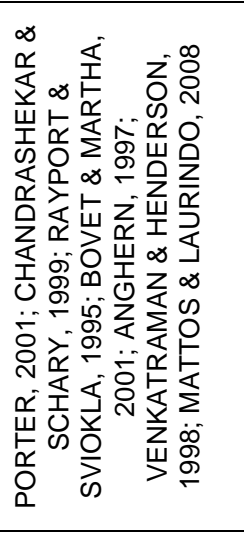 & $\begin{array}{l}\text { - Pode-se afirmar que houve contribuição da Internet para que a empresas } \\
\text { integrasse suas atividades com clientes/consumidores? Se não houve, qual seria } \\
\text { o motivo? } \\
\text { - Houve influência de DA nessa integração? } \\
\text { - Houve aumento da virtualidade nos negócios? } \\
\text { - A virtualidade afeta toda a organização ou apenas o desenvolvimento de produtos } \\
\text { - For serviços? } \\
\text { através da presença online? Quais seriam esses ativos? O uso desses ativos são } \\
\text { - A empresa possui estratégias e táticas diferenciadas para concorrer no } \\
\text { marketspace? Há indicadores de DA relacionados ao marketspace? } \\
\text { - Houve criação de uma rede de valor populada pelos agentes do sistema de valor? } \\
\text { Existe algum indicador de DA para medir a atividade dessa rede? }\end{array}$ \\
\hline 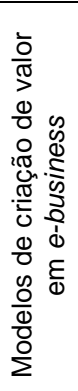 & 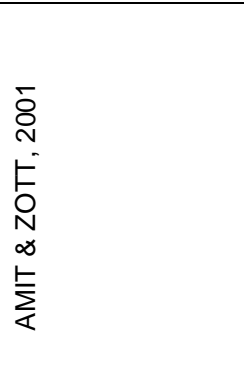 & $\begin{array}{l}\text { - A empresa definiu um modelo de negócios específico para o e-business? Se não, } \\
\text { - } \text { A empresa não definiu? } \\
\text { - Esse modelo promoveu a inovação através de lançamento de novos produtos e } \\
\text { - serviços, novas abordagens com o cliente/consumidor? } \\
\text { - A empresa produziu complementaridades através de parcerias com outras } \\
\text { empresas ou com o próprio cliente/consumidor? } \\
\text { - Pode-se dizer que houve maior fidelização dos clientes/consumidores? } \\
\text { - Como esses impactos em eficiência, inovação, complementaridade e fidelização } \\
\text { foram medidos? Há indicadores de DA relacionados à essa mensuração? }\end{array}$ \\
\hline 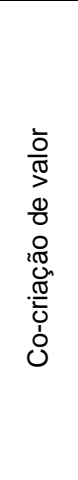 & 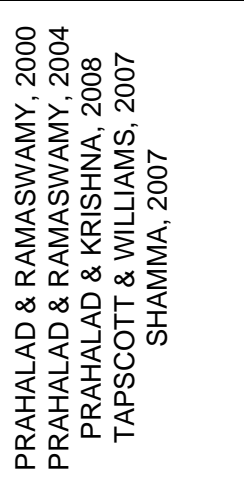 & $\begin{array}{l}\text { - A internet possibilitou a co-criação de valor entre a empresa e seus } \\
\text { clientes/consumidores? } \\
\text { - Quais as evidências dessa co-criação de valor? Há utilização de DA para } \\
\text { mensurar essas evidências? } \\
\text { - Os consumidores/clientes realizaram remixes baseados em produtos e conteúdos } \\
\text { da empresa? Houve mensuração através de DA da propagação desses remixes } \\
\text { em redes sociais? }\end{array}$ \\
\hline
\end{tabular}


Tabela 5.6: Questões do roteiro semi-estruturado relacionadas ao constructo gestão de negócios

\begin{tabular}{|c|c|c|}
\hline $\begin{array}{l}\frac{00}{d 0} \\
\frac{\pi}{\frac{\pi}{\pi}} \\
>\end{array}$ & 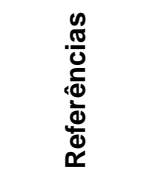 & Questões \\
\hline 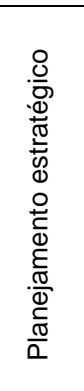 & 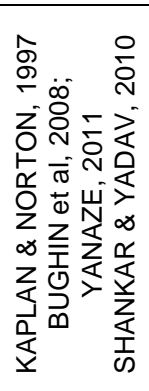 & $\begin{array}{l}\text { - A empresa possui documentação e divulgação de sua estratégia como declarações de } \\
\text { missão, visão e valores? Caso não haja, qual seria o motivo? } \\
\text { - É utilizado um mapa estratégico para divulgação dos objetivos da empresa? } \\
\text { - Os dados digitais de benchmark dos concorrentes foram usados na elaboração do } \\
\text { - Hanejamento estratégico? } \\
\text { - Há indicadores formalizados e assimilados pelos funcionários da empresa? } \\
\text { - Os indicadores de DA influenciaram decisões de negócios que extrapolam a presença } \\
\text { - Online (novos produtos/mudança na comunicação)? } \\
\text { - O planejamento estratégico foi utilizado para definir os objetivos e metas de DA? }\end{array}$ \\
\hline 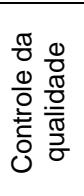 & 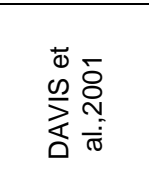 & $\begin{array}{l}\text { - A empresa possui sistemas de qualidade? Se não, qual seria o motivo? } \\
\text { - Esse sistema de qualidade inclui indicadores de DA? } \\
\text { - São utilizadas ferramentas da qualidade na análise dos indicadores de DA? } \\
\text { - Coleta de dados nas mídias sociais e palavras-chave digitadas pelo cliente contribuem } \\
\text { para análises sobre a voz do cliente utilizada no QFD? }\end{array}$ \\
\hline  & 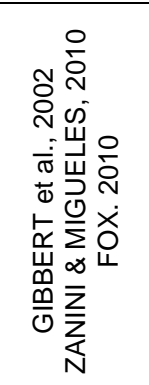 & $\begin{array}{l}\text { - A empresa possui procedimentos para coleta, análise e distribuição da informação } \\
\text { produzida pelos consumidores? Se não, por que? } \\
\text { - DA gera informações utilizadas na gestão do conhecimento do consumidor através de: } \\
\circ \quad \text { Palavras-chave que o consumidor utiliza nos mecanismos de busca } \\
\text { para chegar até o site? } \\
\circ \quad \text { Produtos e serviços mais buscados no site, incluindo aqueles que a } \\
\text { empresa não possui disponibilidade? } \\
\circ \quad \text { Palavras-chave buscadas dentro do próprio site? } \\
\circ \quad \text { Comentários gerados no atendimento ao consumidor? }\end{array}$ \\
\hline 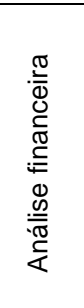 & 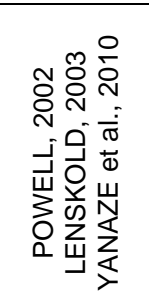 & $\begin{array}{l}\text { - A empresa mensura o retorno de investimento em comunicação? Se não, por quê? } \\
\text { - Como a empresa mensura esse retorno? } \\
\text { - A empresa considera moedas financeiras e não financeiras no cálculo do retorno de } \\
\text { - Há registros do custo/benefício dos esforços de comunicação online? Esses registros } \\
\text { - Hão utilizados para melhoria contínua dos investimentos? } \\
\text { - Há uso de ferramentas financeiras como VPL,TIR e prazo para Payback nas análises de } \\
\text { retorno de investimento em comunicação online? }\end{array}$ \\
\hline
\end{tabular}




\subsection{Teste piloto}

O roteiro semi-estruturado foi testado no caso $A$, que é a empresa de desenvolvimento de software de comércio exterior. Sua aplicação levou a algumas reflexões que foram incorporadas ao roteiro. As alterações mais relevantes referem-se ao escopo das análises de DA e das transformações no sistema de valor.

Ao se testar o roteiro ficou claro que algum dos temas de DA podem não ter aplicação na empresa analisada. Por exemplo, a empresa A não realiza análise dos comentários nas mídias sociais, pois os executivos dessa empresa acreditam que os clientes dessa empresa utilizam outras formas de interação, como feiras e encontros pessoais. Portanto, antes de se perguntar como a empresa usa análises de mídias sociais, foi adicionada uma pergunta anterior ao roteiro: no mercado em que a empresa atua, os comentários publicados nas mídias sociais são relevantes para estratégia de comunicação da empresa? Caso a resposta seja negativa, pergunta-se por que as mídias sociais não são relevantes, pois mais importante do que registrar a não aplicação da análise é saber por que motivo a empresa não a considera relevante. Essa alteração foi replicada para quase todas as variáveis do roteiro. A discussão do teste piloto durante a qualificação da tese ensejou outras melhorias no planejamento da pesquisa como:

- Modelo conceitual mais robusto, incluindo a contribuição do benchmark dos concorrentes na definição de metas para o planejamento estratégico (YANAZE, 2011);

- Adição de proposição sobre a virtualidade dos negócios (ANGHERN, 1997) na variável Mudanças no Sistema de Valor do constructo Contribuição de DA para Estratégia;

- Adição de questionamentos no roteiro relacionados aos objetivos do processo de DA, aos recursos que implementam DA nas empresas e ao uso de fontes de informações digitais sobre fornecedores. 


\subsection{Coleta dos dados}

Com o planejamento da pesquisa devidamente adaptado após o teste piloto e a qualificação, chegou-se a um roteiro aperfeiçoado. Com esse roteiro, foi realizada a coleta dos dados dos estudos de caso através de entrevistas com os executivos da área de negócios e de tecnologia.

Complementarmente às entrevistas foram usadas outras fontes como pesquisas de mercado, visita ao site e perfil nas mídias sociais da empresa e de concorrentes, análise dos relatórios de audiência do site (apenas quando autorizado), leitura de comentários nas mídias sociais sobre a empresa.

\subsection{Análise dos casos e contribuição à teoria}

Os estudos de casos foram analisados de acordo com o framework de DA. Foi interpretado o grau de aderência das práticas a cada variável proposta no framework de acordo com a aplicação do roteiro semi-estruturado. O nível de aderência foi classificado de acordo com uma escala Likert de cinco itens:

- Muito forte - Empresa realiza as práticas mencionadas na variável

- Forte - Empresa realiza as práticas na maioria dos casos

- Razoável - Empresa realiza as práticas eventualmente

- Fraca - Empresa realiza as práticas raramente

- Muito fraca - Empresa não realiza as práticas citadas na variável

Por utilizar esse tipo de escala, as variáveis são consideradas categóricas do tipo ordenada, sendo limitado o uso de inferências estatísticas como a média e o desvio padrão. Por esse motivo, será utilizada a mediana para representar o valor agregado das observações.

A classificação das variáveis foi baseada na interpretação dos estudos de caso. Por exemplo, ao se analisar a variável Inteligência Competitiva do constructo Capacidade Analítica verificou-se que a empresa de software:

- Analisou a audiência dos sites que fornecem software de comércio exterior e realizou benchmark através de visitas a esses sites;

- Estudou as palavras-chave que os consumidores digitavam para chegar até o site e gerou insights a partir desses dados; 
- Comparou a posição da empresa com seus concorrentes no ranking dos principais mecanismos de busca;

- Mapeou o mercado de comércio exterior conforme dados disponíveis na base do Ministério do Desenvolvimento, Indústria e Comércio Exterior (MDIC, 2008).

Foi verificado o uso das práticas citadas na variável Inteligência Competitiva e por isso a aderência foi classificada como muito forte nesse estudo de caso.

No capítulo de análise dos resultados, foram realizadas análises transversais para realização do objetivo principal e dos objetivos específicos i, ii, iii e iv da pesquisa. Ao final desse capítulo, produziu-se um diagnóstico sobre como as empresas brasileiras criam valor através de DA verificando-se as proposições P1, P2 e P3.

\subsection{Limitações da pesquisa}

A survey exploratória indicou quais as práticas de DA mais utilizadas pelas empresas, no entanto, as sete variáveis analisadas não fornecem o aprofundamento de como essas práticas são adotadas.

Devido ao tempo da pesquisa e ao acesso restrito aos executivos da corporação foram analisadas sete empresas, no caso de conglomerados empresariais, as entrevistas foram limitadas aos gestores da unidade de negócios analisada. Esses estudos de caso aprofundaram o entendimento sobre o uso de DA, porém esse conhecimento é limitado às empresas e unidades de negócio analisadas. Sendo limitado o potencial para generalização das conclusões do estudo. 


\section{Pesquisa exploratória}

\subsection{Aplicação de DA pelas empresas brasileiras}

No ano de $2009,50 \%$ das empresas listadas entre as maiores e melhores de Exame utilizavam alguma ferramenta de análise da audiência no site. Já em 2010, esse número evoluiu para $74 \%$, indicando uma forte tendência de usar as práticas de DA entre essas empresas (WA, 2009; 2010).

Entre as ferramentas mais usadas por essas empresas destaca-se o Google Analytics (GA) com $54 \%$ do mercado (figura 6.1). Além do Google Analytics possuir a maior parte das funcionalidades das outras ferramentas, ela é gratuita (CUTRONI, 2010). A implantação é relativamente simples e há também uma série de empresas certificadas para realizar implantações mais complexas.

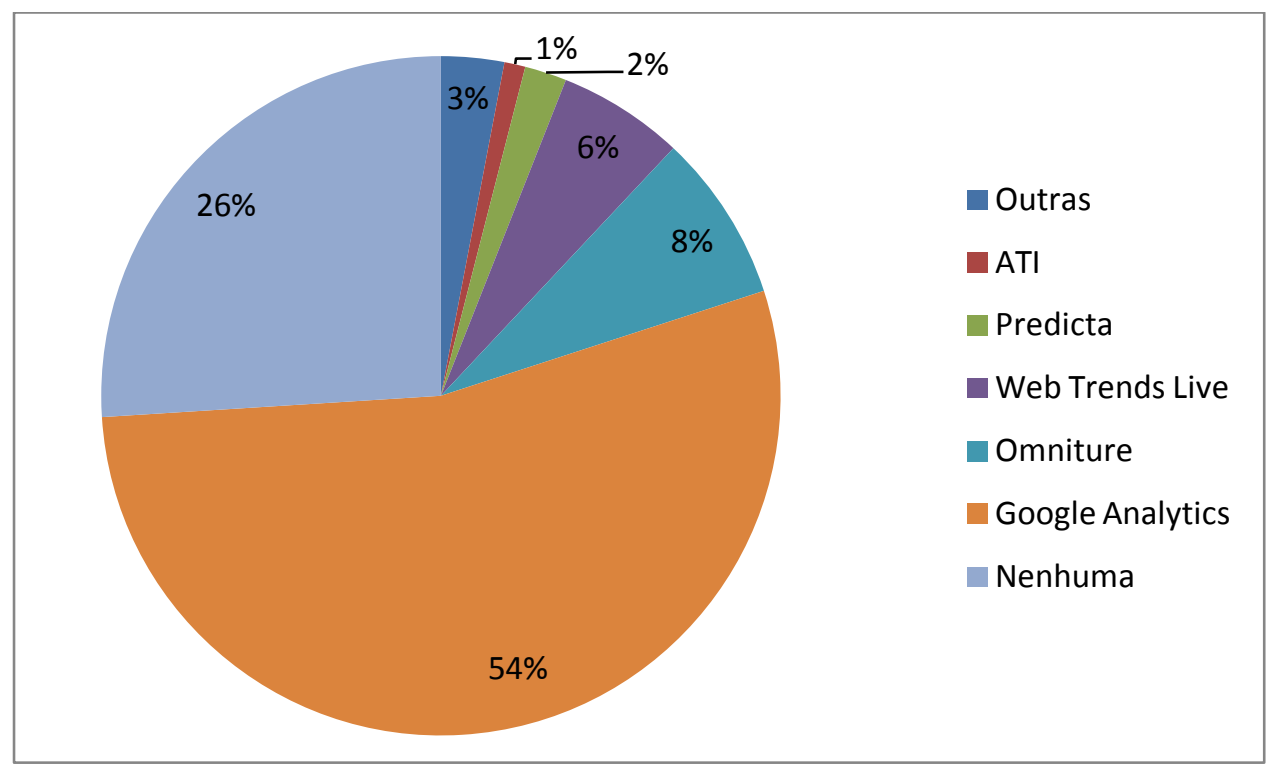

Figura 6.1: Distribuição das ferramentas de DA entre as maiores empresas de Exame (WA, 2010)

O Google Analytics e o Yahoo Analytics são ferramentas gratuitas e baseadas em tags colocados no código do site. Os dados gerados pelas tags são enviados para um servidor externo e a partir desse servidor são oferecidos os relatórios de DA. A figura 6.2 ilustra o processo de uma ferramenta baseada em tags onde ocorrem as seguintes etapas (CUTRONI, 2010)

1. O navegador do usuário solicita uma página ao servidor 
2. Essa página possui uma tag que aciona uma comunicação com o servidor da ferramenta de monitoramento. O servidor gera cookies para serem enviados para a máquina do usuário.

3. Cookies de navegação são inseridos na máquina do usuário para que ele seja rastreado

4. A informação sobre o usuário é passada ao servidor de monitoramento

5. As atualizações de log do site são atualizadas

6. Processamento das buscas realizadas no site

7. Criação de campos para organização das informações

8. Aplicação de filtros

9. Criação de relatórios

10. As informações são consolidadas num database que será acessado pela aplicação de DA

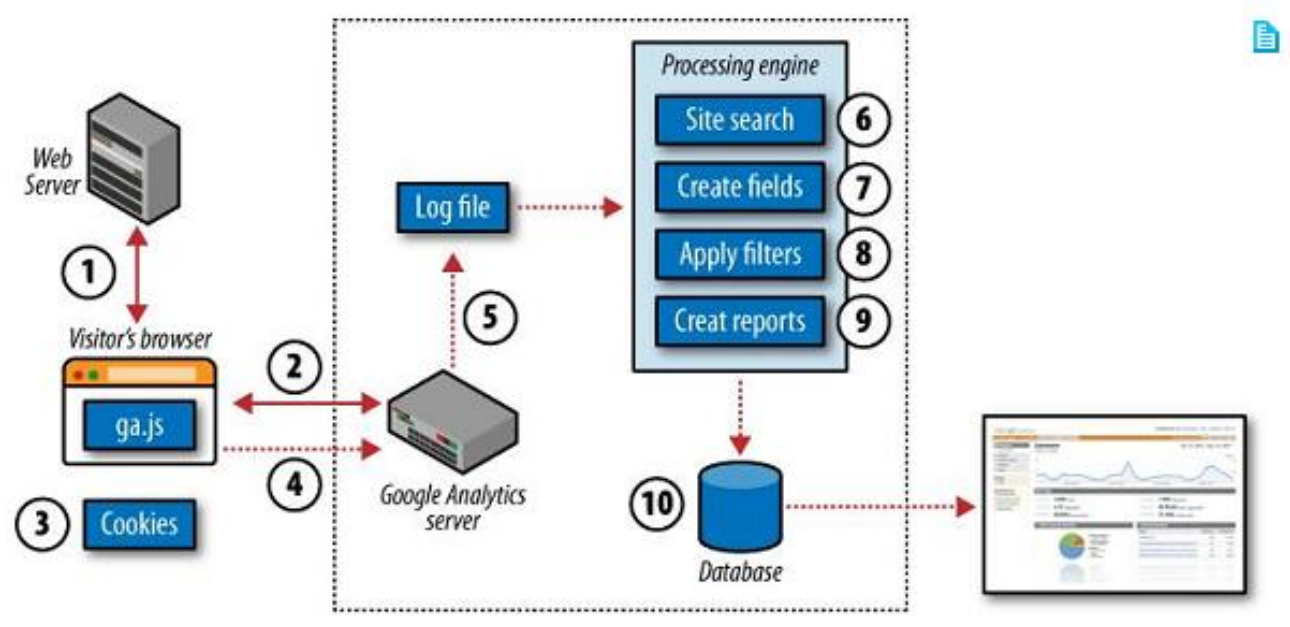

Figura 6.2: Fluxo de uma ferramenta de análise da audiência do site (CUTRONI, 2010) Além das informações colhidas na literatura e nos relatórios de consultorias, foi realizada uma pesquisa de campo entre 2010 e 2011, incluindo uma survey com 76 empresas selecionadas aleatoriamente para entender o uso de ferramentas de DA. As perguntas iniciais procuravam explicar o perfil da empresa, conforme tabela 6.1 , onde as respostas mais freqüentes são coloridas com a cor mais escura.

A ampla maioria das empresas possui site com informações institucionais, 96\%. \% usam aplicações mais sofisticadas para troca de dados pela Internet. A maioria dos respondentes concordou que o e-commerce possibilitou o acesso a novos mercados para compra e venda, essas empresas usam a 
internet com frequência para realização de vendas para clientes/consumidores. A internet também cumpre papel relevante na prestação de serviços, $69 \%$ concordaram com essa afirmação, sendo que 57\% dos clientes usam o site frequentemente para realização de serviços. Portanto verifica-se que internet é importante para os negócios nas empresas pesquisadas.

Tabela 6.1: Uso da internet pelas empresas pesquisadas (as cores mais escuras indicam maior frequencia de respostas)

\begin{tabular}{|c|c|c|c|c|c|}
\hline & $\begin{array}{l}\text { discordo } \\
\text { comple- } \\
\text { tamente }\end{array}$ & $\begin{array}{c}\text { discordo } \\
\text { parcial- } \\
\text { mente }\end{array}$ & $\begin{array}{l}\text { Indife- } \\
\text { rente }\end{array}$ & $\begin{array}{l}\text { concordo } \\
\text { parcial- } \\
\text { mente }\end{array}$ & $\begin{array}{l}\text { concordo } \\
\text { completa } \\
\text { mente }\end{array}$ \\
\hline $\begin{array}{l}\text { Possui site com informações } \\
\text { institucionais }\end{array}$ & $4 \%$ & $0 \%$ & $0 \%$ & $11 \%$ & $85 \%$ \\
\hline Usa troca eletrônica de dados (EDI /B2B) & $12 \%$ & $12 \%$ & $3 \%$ & $23 \%$ & $50 \%$ \\
\hline $\begin{array}{l}\text { Usou no passado troca eletrônica de } \\
\text { dados (EDI/B2B) }\end{array}$ & $16 \%$ & $11 \%$ & $9 \%$ & $18 \%$ & $46 \%$ \\
\hline $\begin{array}{l}\text { O comércio eletrônico possibilitou o } \\
\text { acesso a novos mercados para vendas }\end{array}$ & $13 \%$ & $5 \%$ & $14 \%$ & $30 \%$ & $38 \%$ \\
\hline $\begin{array}{l}\text { O comércio eletrônico possibilitou o } \\
\text { acesso a novos mercados para compras }\end{array}$ & $16 \%$ & $6 \%$ & $16 \%$ & $31 \%$ & $31 \%$ \\
\hline $\begin{array}{l}\text { Vende freqüentemente aos } \\
\text { consumidores finais através do comércio } \\
\text { eletrônico }\end{array}$ & $40 \%$ & $10 \%$ & $9 \%$ & $16 \%$ & $26 \%$ \\
\hline $\begin{array}{l}\text { Vende freqüentemente a outras } \\
\text { empresas através do comércio } \\
\text { eletrônico }\end{array}$ & $39 \%$ & $11 \%$ & $7 \%$ & $23 \%$ & $21 \%$ \\
\hline $\begin{array}{l}\text { Usa freqüentemente comércio } \\
\text { eletrônico para comprar de outras } \\
\text { empresas }\end{array}$ & $21 \%$ & $15 \%$ & $13 \%$ & $37 \%$ & $15 \%$ \\
\hline $\begin{array}{l}\text { Presta serviços através da Internet para } \\
\text { seus clientes }\end{array}$ & $22 \%$ & $7 \%$ & $1 \%$ & $37 \%$ & $32 \%$ \\
\hline $\begin{array}{l}\text { Os clientes usam frequentemente os } \\
\text { serviços disponíveis no site }\end{array}$ & $11 \%$ & $20 \%$ & $12 \%$ & $21 \%$ & $36 \%$ \\
\hline
\end{tabular}

Com relação ao uso de práticas de DA, nota-se que 68\% das empresas utilizam a internet para captar informações dos concorrentes. O que revela uma contribuição forte da internet para a inteligência competitiva.

Verifica-se que a maioria das empresas (52\%) utilizam a web para captar informações de prospects na Internet, enquanto $48 \%$ dessas empresas analisam dados de navegação do cliente na web. Uma possibilidade é que as empresas utilizam pesquisas de mercado para verificar a audiência do público- 
alvo na internet, ou visitam sites de empresas que podem se tornar clientes no caso de serem B2B.

Grande parte das empresas (58\%) analisa o que os clientes falam nas mídias sociais. Um número surpreendente, maior até do que os $50 \%$ de empresas que possuem ferramenta para análise de navegação dos clientes.

Metade das empresas possui ferramenta instalada para análise da navegação dos usuários. Um número abaixo dos $74 \%$ de frequência vista na pesquisa com as maiores empresas de Exame (WA, 2010), entende-se que empresas de maior porte, possuem maior preocupação com a análise de navegação no site e devem ter equipe preparadas para implantar as ferramentas de coleta e análise dos dados.

$57 \%$ das empresas possuem procedimentos sistemáticos para analisar os dados coletados sobre os clientes na Internet e $44 \%$ possuem procedimentos para captar dados nas redes sociais indicando práticas constantes de DA.

Tabela 6.2: Uso de práticas de DA pelas empresas pesquisadas (as cores mais escuras indicam maior frequencia de respostas)

\begin{tabular}{|c|c|c|c|c|c|}
\hline & $\begin{array}{l}\text { discordo } \\
\text { comple- } \\
\text { tamente }\end{array}$ & $\begin{array}{l}\text { discordo } \\
\text { parcial- } \\
\text { mente }\end{array}$ & $\begin{array}{l}\text { Indife- } \\
\text { rente }\end{array}$ & $\begin{array}{l}\text { concordo } \\
\text { parcial- } \\
\text { mente }\end{array}$ & $\begin{array}{l}\text { concordo } \\
\text { completa } \\
\text { mente }\end{array}$ \\
\hline $\begin{array}{l}\text { Capta dados de concorrentes na } \\
\text { Internet para realização de benchmark? }\end{array}$ & $16 \%$ & $9 \%$ & $8 \%$ & $30 \%$ & $38 \%$ \\
\hline $\begin{array}{l}\text { Capta dados de não clientes (prospects) } \\
\text { na Internet para geração de negócios? }\end{array}$ & $14 \%$ & $17 \%$ & $17 \%$ & $22 \%$ & $31 \%$ \\
\hline $\begin{array}{l}\text { Analisa o comportamento dos clientes } \\
\text { que navegam, transacionam ou usam } \\
\text { serviços no site da empresa (web } \\
\text { analytics)? }\end{array}$ & $23 \%$ & $19 \%$ & $10 \%$ & $19 \%$ & $29 \%$ \\
\hline $\begin{array}{l}\text { Tem procedimentos sistemáticos para } \\
\text { analisar os dados coletados sobre os } \\
\text { clientes no site da empresa? }\end{array}$ & $27 \%$ & $18 \%$ & $8 \%$ & $22 \%$ & $25 \%$ \\
\hline $\begin{array}{l}\text { Possui ferramentas específicas (web } \\
\text { analytics) para coleta e análise dessas } \\
\text { informações }\end{array}$ & $33 \%$ & $19 \%$ & $8 \%$ & $13 \%$ & $27 \%$ \\
\hline $\begin{array}{l}\text { Sua empresa analisa o que seus clientes } \\
\text { dizem nas mídias sociais (blogs, orkut, } \\
\text { facebook, fóruns)? }\end{array}$ & $25 \%$ & $13 \%$ & $4 \%$ & $32 \%$ & $26 \%$ \\
\hline $\begin{array}{l}\text { Tem procedimentos sistemáticos para } \\
\text { analisar os dados coletados sobre os } \\
\text { clientes nas redes sociais? }\end{array}$ & $34 \%$ & $13 \%$ & $9 \%$ & $21 \%$ & $23 \%$ \\
\hline
\end{tabular}


Com essas informações conclui-se que dentre as práticas de DA as mais usadas pelas empresas são:

1 Realizar benchmark dos concorrentes $-68 \%$

2 Analisar redes sociais $-58 \%$

3 Captar dados de prospects $-53 \%$

4 Analisar dados de navegação do cliente - 48\%

As respostas demonstram que as empresas tendem a usar DA para coletar informações sobre o mercado e também para gerar novas oportunidades de negócios, com preocupação menor para a usabilidade do site e análise dos comportamentos dos clientes. Embora as empresas possuam sites que, em sua maioria, realizam vendas e prestam serviços para os clientes.

\subsection{Temas mais frequentes entre profissionais de DA}

Para saber mais sobre as preocupações e interesses debatidos pelos profissionais de DA, foi realizada uma segunda etapa da pesquisa de campo, dessa vez através de uma pesquisa qualitativa baseada em cerca de 12.000 publicações no fórum de DA do Brasil, grupo web analytics_brasil do site do Yahoo.

Nota-se pela figura 6.3 que a maior preocupação dos profissionais é relacionada às ferramentas de coleta de dados de navegação, com ampla participação das questões sobre o Google Analytics. Técnicas para trazer visitantes a partir de mecanismos de busca como search engine optimization (SEO) e search engine marketing (SEM) também são bastante debatidas.

As questões relacionadas a análises de campanhas, mídias sociais e relatórios de usabilidade são mais raras, sendo um indício de que esses profissionais não focam nessas análises.

Por último, vê-se que o fórum é também utilizado para publicação de vagas de DA, indicando que o mercado está aquecido para os profissionais de DA. 


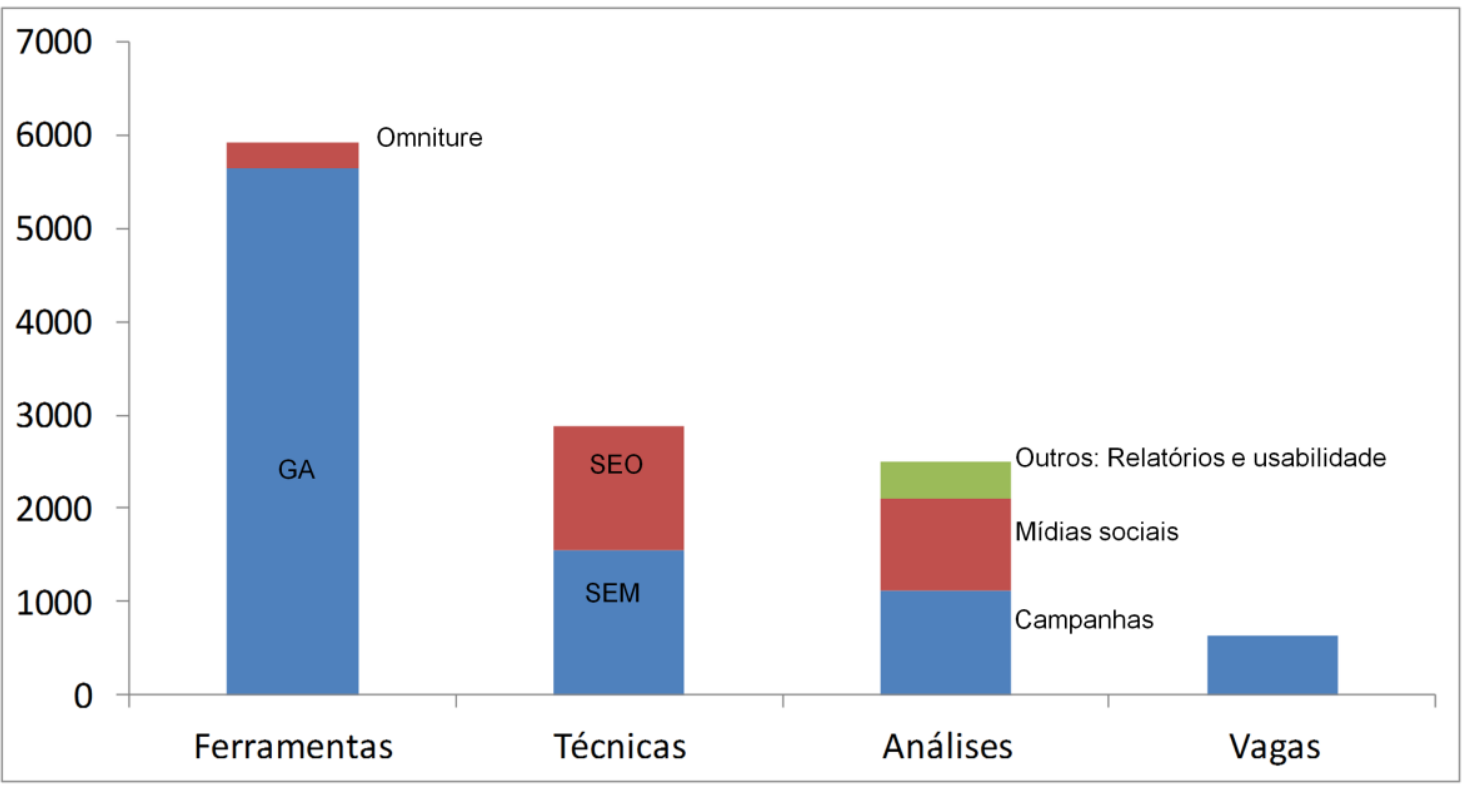

Figura 6.3: Temas mais frequentes no fórum Web Analytics Brasil 


\section{Estudos de caso}

A seguir, serão analisados os múltiplos estudos de caso de acordo com o protocolo apresentado na metodologia. Foram analisados sete segmentos distintos: Software; Automobilístico, Vestuário; Bebidas; Editora; E-commerce; e Fonográfico.

Os estudos de casos seguirão uma estrutura que facilita o entendimento do cenário analisado. Em primeiro lugar, será descrito o contexto da empresa, através dos seguintes tópicos:

- As informações sobre a indústria;

- Os produtos e serviços da empresa;

- A estratégia genérica;

- A forma como a tecnologia é organizada;

- A presença online da empresa;

- A estrutura e a organização das atividades de DA.

Em seguida serão analisadas as questões dos constructos competência analítica, contribuições da DA para estratégia e gestão de negócios. Por fim, será realizada uma síntese dos resultados gerados por DA em cada empresa. A aderência a cada variável do constructo será medida numa escala Likert conforme citado na metodologia. A aderência a cada variável será representado num quadro resumo de cada caso.

\subsection{Estudo de caso A: Empresa de software}

\subsubsection{Contexto da empresa}

\subsubsection{Informações sobre a indústria}

A indústria de software possui crescimento acentuado no mercado nacional e global. Os gastos brasileiros com TI em 2011 foram de 42 bilhões, representando 2,0 \% do PIB, maior proporção entre todos os BRIC. A inclusão digital da população favorece crescimento dos investimentos em TI (CARVALHO, 2011).

O crescimento do mercado de TI será de $11 \%$ ao ano entre 2011 e 2015. As seguintes tendências serão importantes nesse crescimento: aplicações e 
serviços de mobilidade; cloud computing; grandes volumes de dados e segmentação; e soluções verticalizadas e especializadas para mercados específicos (CARVALHO, 2011; PERES, 2010).

Considerando a atratividade da indústria (PORTER, 1979), podemos verificar que o segmento é altamente competitivo com o impacto das forças variando de médio para alto (Figura 7.1).

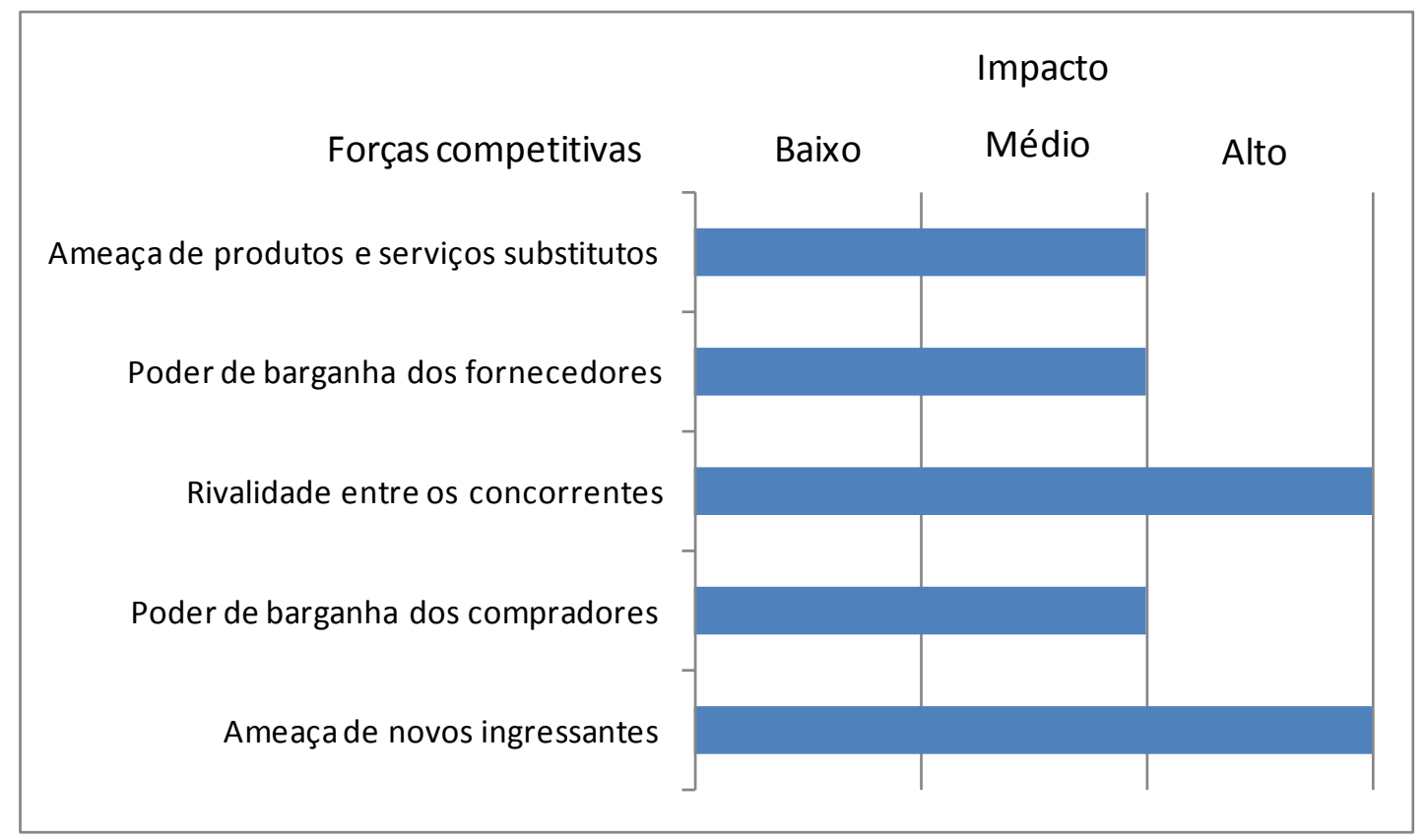

Figura 7.1: Impacto das forças competitivas para o mercado de software (Elaborado pelo autor, baseado em Porter, 1979)

\subsubsection{Estratégia genérica}

Para sobreviver nesse mercado altamente competitivo, a empresa adotou a estratégia genérica de enfoque. A empresa optou por trabalhar no segmento de software de comércio exterior (COMEX), sendo que desse segmento, a maior participação da carteira é de clientes de médio porte.

A escola

\subsubsection{Produtos e serviços da empresa}

A empresa fornece dois tipos de produtos e serviços:

- Um pacote de gestão das operações de comércio exterior com implementação na estrutura de $\mathrm{Tl}$ da empresa compradora. $\mathrm{Na}$ implantação do pacote podem ser realizadas customizações, cenário bastante comum em empresas que utilizam sistemas de ERP. A 
empresa para pela compra do software e pela atualização das versões. Os serviços de customização são comprados à parte.

- Um produto do tipo software as a service (SAAS), onde o usuário pode acessar todas as funcionalidades do produto através de uma intranet. $O$ pagamento do serviço é mensal e as atualizações são feitas para todos os clientes, uma vez que a versão do software é a mesma para todos os compradores. Por possuir preço mais baixo e ser de mais simples implementação, o pacote pode ser usado também por empresas de pequeno porte.

\subsubsection{Organização da tecnologia}

A área de $\mathrm{Tl}$ da empresa é composta basicamente de desenvolvedores. A empresa possui cerca de 15 desenvolvedores, divididos em atividades de desenvolvimento do aplicativo SAAS e implementações do produto em ambientes de clientes. A plataforma do software de COMEX é Java e a estrutura de hosting do site é terceirizada.

\subsubsection{Presença online}

A empresa possui um site onde exibe seus produtos e oferece a possibilidade dos seus possíveis clientes fazerem o agendamento de uma visita para demonstração do produto (lead).

O site possui uma área restrita para que os clientes que possuem a versão do software implantada em seus servidores possam fazer o download de patches com versões atualizadas e também recorram ao suporte do produto. Os clientes da versão SAAS utilizam o site para utilizar o software.

A empresa realiza campanhas de links patrocinados no Google gerenciando essas campanhas no Google Adwords.

\subsubsection{Estrutura e organização das atividades de DA}

As atividades de DA foram gerenciadas por uma consultoria no momento de implantação das métricas. Essa consultoria foi responsável por fazer o alinhamento entre a estratégia e a presença online, gerenciou 0 desenvolvimento do novo site e elaborou um plano de ação. A partir desse plano de ação, foram estabelecidas as metas para os indicadores de DA e foi 
entregue um painel de controle para acompanhamento dos indicadores. Esse painel foi implementado com a ferramenta Google Analytics.

Após a implantação do painel, os executivos da empresa passaram a acompanhar os indicadores e tomarem decisões para gerenciar 0 relacionamento com os seus clientes. Uma pessoa da área financeira era responsável por autorizar e gerenciar as campanhas de links patrocinados, o próprio dono da empresa acompanhava a taxa de conversão do site e se os leads gerados eram convertidos em novos clientes.

\subsubsection{Capacidade analítica}

\subsubsection{Inteligência competitiva}

A empresa analisou a audiência dos sites de comércio exterior, a colocação dos mesmos nos rankings de mecanismos de busca, assim como fez uma análise profunda do site dos concorrentes diretos e avaliou a posição destes no ranking de palavras-chave do Google. A empresa também mapeou o mercado de comércio exterior conforme dados disponíveis na base do Ministério do Desenvolvimento, Indústria e Comércio Exterior (MDIC, 2008) (Tabela 7.1).

Após a implantação dos indicadores de DA, a empresa passou a analisar as palavras-chave que os consumidores digitavam para chegar até o site. Além das palavras-chave óbvias, como "software para comércio exterior" e "software de COMEX", a empresa descobriu algumas palavras-chave que eram indícios de cauda longa (BRYNJOLFSSON, 2003; ANDERSON, 2006), um exemplo ilustrativo eram termos como "quero exportar" que indicavam que a empresa tinha necessidades maiores além de comprar o software de comércio exterior. A empresa necessitava de informações mais básicas, como saber 0 procedimento para exportar e importar. A partir desse insight a empresa conseguiu entender melhor seus clientes e montou um posicionamento diferenciado para que o produto SAAS tivesse uma interface para empresas que possuem pouca familiaridade com os processos de COMEX.

\subsubsection{Otimização da presença ativa}

No segmento analisado, é bastante comum as empresas utilizarem mecanismos de busca em suas estratégias de comunicação. Isso ocorre, pois através desses mecanismos, as empresas conseguem atingir o possível cliente 
no exato momento em que ele está buscando o produto. Como se trata de um produto muito específico, software de COMEX, a possibilidade de haver outros espaços para anunciar esse produto é bastante limitada. Os poucos sites de COMEX cobram preços altos pela exposição de mídia.

Após a implementação do painel de controle, a empresa teve redução significativa dos custos por cliques. Esse custo por clique é uma variável importante no custo de aquisição de novos leads, assim como a taxa conversão de visitas em leads.

A empresa também adotou táticas de SEO para melhorar a posição do site nos rankings de busca do Google.

Tabela 7.1: Estudo do Mercado de Comércio Exterior (MDIC, 2008)

\begin{tabular}{|l|l|l|l|l|}
\hline Faixa & Importação & Exportação & Total & Concorrentes \\
\hline Acima de US\$ 50 milhões & 495 & 600 & 1.095 & Grandes consultorias \\
\hline $\begin{array}{l}\text { Entre US\$ 10 e 50 } \\
\text { milhões }\end{array}$ & 1.512 & 1.344 & 2.856 & $\begin{array}{l}\text { Softwarehouses de COMEX } \\
\text { para empresas de grande } \\
\text { porte, empresa analisada }\end{array}$ \\
\hline Entre US\$1 e 10 milhões & 6.290 & 4.260 & 10.550 & Softwarehouses de COMEX \\
Até US\$1 milhão & 28.546 & 16.817 & 45.363 & $\begin{array}{l}\text { para empresas de menor } \\
\text { porte, empresa analisada }\end{array}$ \\
\hline Soma & $\mathbf{3 6 . 8 4 3}$ & $\mathbf{2 3 . 0 2 1}$ & $\mathbf{5 9 . 8 6 4}$ & \\
\hline
\end{tabular}

\subsubsection{Mídias sociais}

Embora as mídias sociais possam representar vantagens tanto para empresas do ramo $\mathrm{B} 2 \mathrm{C}$ como $\mathrm{B} 2 \mathrm{~B}$, os executivos da empresa decidiram não possuir uma presença estruturada nas mídias sociais através de perfis e fan pages.

Com base nas entrevistas, ficou a impressão que dois fatores pesaram nessa decisão: a postura conservadora dos sócios que temem pela exposição da empresa nas mídias sociais, embora a empresa já possa ser comentada espontaneamente por seus clientes; e a dificuldade para atualização periódica das informações nos perfis da empresa.

\subsubsection{Usabilidade}

As métricas de usabilidade foram acompanhadas pela empresa, principalmente aquelas relacionadas à conversão de visitas em clientes. No entanto, a 
agilidade para realizar mudanças no site foi baixa devido a uma série de mudanças estruturais que a empresa estava passando.

A própria estrutura do site dificultava as alterações, pois eram necessários os serviços de profissionais especializados. Por causa disso, os executivos decidiram mudar a área aberta do site para uma plataforma Wordpress, dessa forma terão mais flexibilidade para fazer as alterações.

\subsubsection{Convergência}

A empresa quase não realiza ações offline, com exceção de algumas feiras do mercado de COMEX. Ficando difícil estabelecer uma relação entre campanhas online e offline.

No entanto, pode-se dizer que a análise do consumidor no site, mais notoriamente a análise das palavras-chave, foi importante na definição de novos produtos e serviços, vide exemplo, do posicionamento do produto SAAS baseado no entendimento sobre o comprador.

\subsubsection{Contribuições da Internet para estratégia}

\subsubsection{Alinhamento entre estratégia e TI}

O pensamento sobre estratégia vigente nessa empresa é de planejamento (MINTZBERG \& LAMPEL, 1999). É utilizado o Balance Score Card (KAPLAN \& NORTON, 1997) para mapear os objetivos estratégicos que dá origem às metas e planos de ação elaborados anualmente.

A empresa possui um alinhamento entre Estratégia e TI que pode ser entendido como "Transformação Tecnológica" de acordo com o referencial de Henderson \& Venkatraman (1993). Ao elaborar uma estratégia em que pretende atrair o segmento de mercado de pequenas empresas com um software SAAS, a empresa utilizou uma estratégia de TI diferenciada para realizar a sua estratégia de negócios, modificando sua estrutura de TI através da contratação de desenvolvedores Java e mudando a arquitetura do software fornecido ao mercado.

Pode-se dizer que o grau de alinhamento da estratégia com a TI está no nível 4, melhoria no gerenciamento de processos, pois os investimentos em $\mathrm{TI}$ geram retornos e há uma compreensão plena de TI pelo negócio e vice-versa. 
(LUFTMAN, 2003). Há uma visão de processos inicial, ainda que haja um forte peso da organização por departamentos.

A implantação de DI segue 0 alinhamento estratégico, pois auxilia a transformação tecnológica fornecendo indicadores de qualidade e de retorno sobre investimento aos departamentos.

Seguindo o referencial de (BUCHANAN \& LINOWES, 1980), pode-se dizer que há centralização na execução e no controle das operações dos sistemas de DA, a empresa manipula os relatórios, estipula metas e toma decisões com base nos indicadores de DA. As atividades de execução e controle do desenvolvimento são terceirizadas e executadas por uma consultoria especializada.

\subsubsection{Sistema de valor}

Pode-se afirmar que a empresa conseguiu construir links mais fortes com seus consumidores devido à sua presença na Internet (PORTER, 2001). Seria exagerado dizer que a empresa construiu uma rede de valor (BOVET \& MARTHA, 2001) com os agentes na Internet, sobretudo porque ela não estabeleceu parcerias mais profundas com seus fornecedores e outros players do mercado.

A empresa valeu-se dos espaços virtuais definidos por Anghern (1997) para divulgar seus produtos, se comunicar com seus clientes e distribuir seus serviços na modalidade SAAS e também os releases da versão servidor.

As métricas de DA são importantes nesse relacionamento estreito com o consumidor. E o produto SAAS pode ser considerado um ativo digital apoiado pelos insights de DA.

Percebe-se que a virtualidade foi limitada no âmbito da organização (VENKATRAMAN \& HENDERSON, 1998) e foi expressiva no desenvolvimento de produtos (MATTOS \& LAURINDO, 2008).

\subsubsection{Modelos de criação de valor em e-business}

A empresa conseguiu estabelecer avanços em todos os direcionadores de criação de valor estabelecido por Amit \& Zott (2001):

- Conseguiu ser inovadora em seu produto SAAS; 
- Aumentou a sua eficiência no atendimento e no processo de prospecção;

- Obteve complementaridade ao fazer parceria com o fornecedor de informações de COMEX;

- Fidelizou seus clientes ao estreitar o relacionamento através da Internet.

\subsubsection{Co-criação de valor}

Houve co-criação de valor através do monitoramento das palavras-chave digitadas pelas empresas que visitaram o site, a empresa conseguiu montar um posicionamento para clientes de pequeno porte baseado no seu produto SAAS e na melhoria das campanhas de links patrocinados no Google. No entanto, não há formas explicítas de o consumidor co-desenvolver o software junto com a empresa.

\subsubsection{Estratégia para mercados segmentados}

Conforme tópico anterior, a empresa conseguiu identificar e montar uma estratégia para nichos específicos de consumidores.

\subsubsection{Gestão de negócios}

\subsubsection{Planejamento estratégico}

As informações de benchmark foram importantes para elaboração do planejamento estratégico. A empresa montou um mapa estratégico (KAPLAN \& NORTON, 1997) onde incluiu os objetivos de sua presença online.

Os indicadores de DA fazem parte dos indicadores do negócio e são acompanhados periodicamente, gerando aprendizados para a estratégia corporativa.

\subsubsection{Controle de qualidade}

A empresa possui um sistema de qualidade para melhoria em seu processo de atendimento e para obter insights de melhoria dos seus produtos. As métricas são baseadas no atendimento online disponível na área interna do site.

O QFD não é utilizado pela empresa, porém, pode-se dizer que a leitura de palavras-chave dos consumidores influencia o desenvolvimento de novos produtos. 


\subsubsection{Gestão de conhecimento do consumidor}

Embora a empresa não tenha um processo formal de gestão do conhecimento, ela se baseia nos anseios de compradores para tomar decisões estratégicas, como dito nos outros tópicos.

As informações sobre as palavras-chave digitadas pelos consumidores estão sistematizadas no sistema Google Analytics e os comentários dos atuais clientes ficam armazenados no sistema de atendimento.

\subsubsection{Análise financeira}

Talvez o indicador de DA mais significativo seja o ROI gerado pelas campanhas na Internet. Esse indicador é tão importante que a própria área financeira se encarrega de monitorar o custo por lead e determina os novos investimentos em campanha baseados nesse acompanhamento.

Não são consideradas moedas não financeiras, nem cálculos mais elaborados como TIR e VPL, mesmo porque o ciclo de retorno sobre investimento é muito curto, cerca de 3 meses, sendo irrelevante o cálculo de custo do capital.

\subsubsection{Síntese do estudo de caso}

Em todos os constructos Capacidade Analítica, Contribuição da Internet para estratégia e Gestão de negócios, a empresa conseguiu uma aderência forte. Essa aderência foi medida de acordo com as variáveis do modelo conceitual conforme demonstrado na tabela 7.2.

No geral, a empresa teve um bom aproveitamento de DA com impacto razoável nos negócios. Após a implantação de DA, a empresa tornou-se mais competitiva e conseguiu agregar novos clientes a sua carteira, além de tornar o relacionamento mais estreito com os clientes conquistados.

\subsection{Estudo de caso B: Montadora}

\subsubsection{Contexto da empresa}

\subsubsection{Informações sobre a indústria}

A indústria automobilística no Brasil teve um crescimento vigoroso nos últimos anos. O número de emplacamentos foi de 5.767 .886 unidades em 2011, ante 5.497.836 unidades em 2010, uma alta de 4,91\%. A partir de 2010, o Brasil 
ocupa a $4^{\mathrm{a}}$ posição em venda de veículos leves, ultrapassando a Alemanha (FENABRAVE, 2012b).

O crescimento nos últimos anos se deve a maior oferta de crédito, ao aumento do poder de consumo da população e à desoneração do IPI, ferramenta utilizada pelo governo para induzir o consumo em época de baixo crescimento econômico.

De maneira geral, os preços praticados pelas montadoras no Brasil são mais altos do que os praticados em outros mercados. Devido à alta tributação e fatores locais como problemas na infra-estrutura do país.

Tabela 7.2: Aderência das práticas da empresa de software às variáveis do framework de DA

\begin{tabular}{|c|c|c|c|}
\hline Constructos & Variáveis & Aderência & Justificativa \\
\hline \multirow[t]{6}{*}{$\begin{array}{l}\text { Capacidade } \\
\text { analítica }\end{array}$} & Inteligência competitiva & Muito forte & $\begin{array}{l}\text { Presença online dos concorrentes e tendências de } \\
\text { mercado acompanhadas regularmente e impactam na } \\
\text { estratégia }\end{array}$ \\
\hline & Otimização de presença ativa & Forte & $\begin{array}{l}\text { Campanhas otimizadas e uso de técnicas de SEO. Mas } \\
\text { presença ativa se resume à mecanismos de busca }\end{array}$ \\
\hline & Mídias sociais & Muito fraca & Empresa não monitora mídias sociais \\
\hline & Usabilidade & Razoável & $\begin{array}{l}\text { Métricas de usabilidade são monitoradas, mas alterações } \\
\text { no site são lentas }\end{array}$ \\
\hline & Convergência & Muito forte & $\begin{array}{l}\text { Insights das buscas do consumidor geraram novos } \\
\text { produtos }\end{array}$ \\
\hline & Mediana do constructo & Forte & \\
\hline \multirow[t]{6}{*}{$\begin{array}{l}\text { Contribuição } \\
\text { da Internet } \\
\text { para estratégia }\end{array}$} & Alinhamento entre estratégia e $\mathrm{TI}$ & Muito forte & $\begin{array}{l}\text { Empresa possui alinhamento maduro do tipo } \\
\text { "Transformação tecnológica", realizou transformações na } \\
\text { organização de acordo com BSC }\end{array}$ \\
\hline & Mudanças no sistema de valor & Forte & $\begin{array}{l}\text { Houve mudanças consideráveis no relacionamento com o } \\
\text { consumidor }\end{array}$ \\
\hline & $\begin{array}{l}\text { Modelos de criação de valor em } \\
\text { e-business }\end{array}$ & Muito forte & $\begin{array}{l}\text { Houve criação de valor nos quatro direcionadores de } \\
\text { criação de valor: inovação, fidelização, eficiência e } \\
\text { complementaridade }\end{array}$ \\
\hline & Co-criação de valor & Razoável & $\begin{array}{l}\text { Insights de DA servem para desenvolver novos produtos, } \\
\text { mas cliente não é co-desenvolvedor direto }\end{array}$ \\
\hline & $\begin{array}{l}\text { Estratégias para mercados } \\
\text { segmentados }\end{array}$ & Forte & $\begin{array}{l}\text { Empresa desenvolveu produto para um segmento } \\
\text { específico (pequenas e médias empresas de COMEX), mas } \\
\text { isso ocorreu apenas para um mercado }\end{array}$ \\
\hline & Mediana do constructo & Forte & \\
\hline \multirow[t]{5}{*}{$\begin{array}{l}\text { Gestão de } \\
\text { negócios }\end{array}$} & Planejamento estratégico & Forte & $\begin{array}{l}\text { Benchmark e indicadores de DA impactam na elaboração } \\
\text { da estratégia. }\end{array}$ \\
\hline & Controle da qualidade & Razoável & $\begin{array}{l}\text { Utilizado principalmente na melhoria do atendimento, } \\
\text { falta visão sistêmica }\end{array}$ \\
\hline & $\begin{array}{l}\text { Gestão do conhecimento do } \\
\text { consumidor }\end{array}$ & Forte & $\begin{array}{l}\text { Não há processo formal, mas a empresa armazena } \\
\text { interações com clientes e toma decisões baseadas nesses } \\
\text { registros }\end{array}$ \\
\hline & Análise financeira & Muito forte & $\begin{array}{l}\text { Indicadores financeiros da presença online são tão } \\
\text { relevantes que a área financeira gerencia campanhas } \\
\text { online }\end{array}$ \\
\hline & Mediana do constructo & Forte & \\
\hline \multicolumn{2}{|c|}{ Aplicação de Digital Analytics } & Forte & $\begin{array}{l}\text { De maneira geral, a empresa utiliza indicadores de DA } \\
\text { para impulsionar sua eficiência e eficácia }\end{array}$ \\
\hline
\end{tabular}

Apesar desses fatores, a indústria pode ser considerada bastante atrativa (PORTER, 1979), com exceção da rivalidade entre as montadoras existentes, 
as outras forças possuem impacto de moderado para baixo. Por exemplo, o transporte público, produto substituto das montadoras, é de péssima qualidade. (figura 7.2).

\subsubsection{Produtos e serviços da empresa}

A montadora analisada possui uma ampla gama de produtos: veículos leves, que vão desde a linha popular até carros de alto luxo; veículos utilitários e caminhões.

O portfólio de produtos é bastante extenso, existindo mais de 20 modelos de veículos leves disponíveis no mercado.

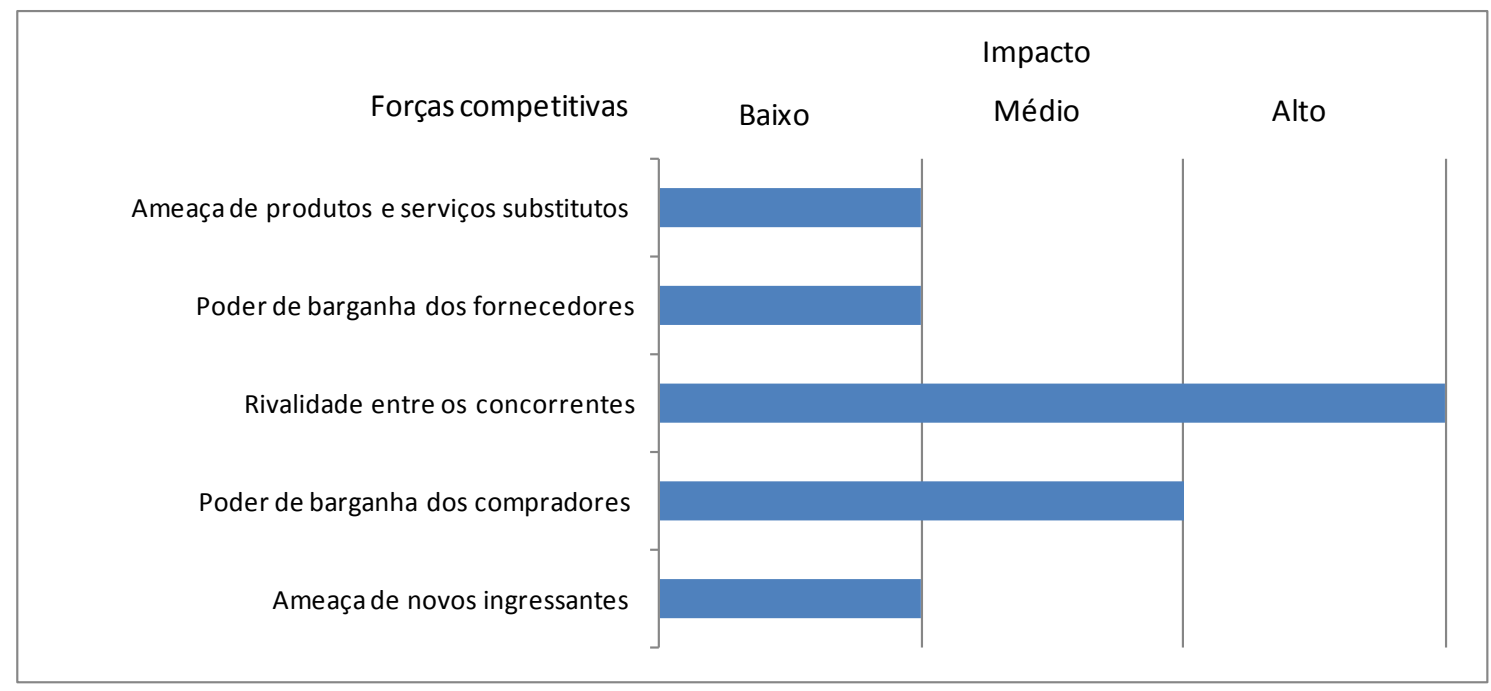

Figura 7.2: Impacto das forças competitivas para o mercado de software (Elaborado pelo autor, baseado em Porter, 1979)

\subsubsection{Estratégia genérica}

A empresa compete através de diferenciação. Seus produtos possuem qualidade reconhecidamente superior, fato comprovado preço ligeiramente mais alto que seus consumidores aceitam pagar pelos seus produtos. A tradição da marca, a abundância de peças de reposição e o alto valor de revenda são outros fatores críticos de sucesso nos quais a empresa possui desempenho superior.

O número de configurações diferentes de cada modelo também pode ser entendido como um diferencial. Embora não seja percebido pelo consumidor com tanta clareza, esse diferencial é importante na regionalização dos produtos, sendo que a concessionária de um determinado estado pode oferecer um produto bastante diferente do encontrado em outra região. 


\subsubsection{Organização da tecnologia}

A área de tecnologia possui uma estrutura bastante complexa proporcional à uma estrutura de grande porte. A estrutura de tecnologia é dividida em quatro grandes áreas: gestão do relacionamento com negócios; administração da TI e de controles internos; gestão de segurança e de riscos; e recursos de $\mathrm{TI}$ e serviços.

A área de gestão do relacionamento possui maior influência na definição dos projetos de presença online. Os integrantes dessa área não são necessariamente especialistas em tecnologia, entre eles há analistas de negócios que procuram entender o custo-benefício de cada projeto e gerentes de projeto, que elaboram o planejamento do projeto. Normalmente, os projetos mais urgentes e de curto prazo são realizados no ambiente da própria empresa, podendo ser executados por funcionários ou por empresas contratadas por regime de banco de horas. Os outros projetos passam são realizados por empresas contratadas ad hoc, que passam por um processo de concorrência intermediado pela área de compras. Considerando apenas os projetos relacionados à presença online, a empresa deve movimentar mais de 30 profissionais entre funcionários e empresas contratadas.

\subsubsection{Presença online}

A presença online da empresa é tão diversa quanto seu portfólio de produtos. Existe um site central da marca que agrupa todos os produtos e serviços, mas o consumidor também pode acessar os sites específicos de cada produto. A empresa também cria sites temporários, hotsites, para campanhas e promoções.

A principal funcionalidade do site central é o aplicativo para montagem do carro. Nesse aplicativo, o consumidor escolhe a configuração do carro, conhece o preço e envia uma intenção de compra (lead). Esse último passo é o mais importante, pois nele o consumidor fornece informações pessoais como email e telefone, que podem ser usadas pela concessionária mais próxima para fechar o processo de compra. 
A presença online é complementada pelo perfil no Facebook e no Twitter. Nesses perfis são postadas informações institucionais e sobre os produtos da marca.

\subsubsection{Estrutura e organização das atividades de DA}

A presença online é monitorada com ferramentas como o Google Analytics e o Omniture. Porém, não há uma visão centralizada sobre o consumidor online, uma vez que cada site pode possuir uma implementação diferente da ferramenta de monitoramento.

As iniciativas de monitoramento também são distintas, uma agência de publicidade que desenvolveu uma campanha, pode monitorar os indicadores de um hotsite dessa campanha. Enquanto que o departamento de varejo, monitora os resultados do aplicativo de montagem do carro no site central. Portanto, existem várias equipes de monitoramento com visões fragmentadas.

\subsubsection{Competência analítica}

\subsubsection{Inteligência competitiva}

A empresa monitora a audiência de sites concorrentes através de pesquisas de mercado. As bases de emplacamentos de carros do Denatran são utilizadas para estudos de participação do mercado e crescimento de cada montadora.

As palavras-chave digitadas pelos consumidores e os comentários nas mídias sociais não são analisados com 0 intuito de fornecer insights para o lançamento de produtos e serviços. Porém, a visualização de detalhes do produto no site podem ser usados como itens de preferência do consumidor. Apesar da abundância de informações, elas são pouco utilizadas na formulação da estratégia da montadora.

\subsubsection{Otimização da presença ativa}

A presença ativa é monitorada através de indicadores de mídia como cobertura, frequência e taxa de cliques. Porém, o monitoramento completo até a intenção de compra do veículo fica comprometido, devido ao problema de fragmentação do monitoramento descrito no tópico Estrutura e organização das atividades de DA. 
Raramente, a empresa calcula o $\mathrm{ROI}$ das campanhas, apenas em alguns casos é feito o cruzamento com dados de emplacamento para saber quanto cada campanha impactou na venda dos veículos.

\subsubsection{Mídias sociais}

Os estudos sobre comentários nas mídias sociais são realizados de maneira ad hoc para questões como o lançamento de um novo produto ou o resultado de uma campanha específica.

Apesar de esses estudos serem esporádicos, quando são realizados, podem levar a resultados interessantes na gestão de campanhas. Em uma campanha recente, a montadora conseguiu viralizar uma promoção na Internet com blogueiros influentes, o que impulsionou o número de cadastros e tornou a marca um trend topic no Twitter no período da ação.

\subsubsection{Usabilidade}

A navegação do usuário é medida em cada site, porém como o monitoramento é fragmentado, a visão da experiência do usuário fica comprometida, limitando em grande proporção as melhorias na usabilidade do site.

\subsubsection{Convergência}

Apenas em algumas situações específicas, como no lançamento de produto ou em campanha promocional, é feito um comparativo entre as ações na web e os resultados gerados no número de emplacamentos dos produtos.

Em termos de sistemas de informação, existe potencial para integrar os dados de interação no site com as informações de vendas nas concessionárias, pois o consumidor insere informações na intenção de compra no site que podem ser cruzadas com os dados de venda do veículo. No entanto, esse potencial não é aproveitado.

\subsubsection{Contribuições da Internet para estratégia}

\subsubsection{Alinhamento entre estratégia e TI}

A escola de pensamente estratégico preponderante nessa empresa é de posicionamento (MINTZBERG \& LAMPEL,1999) pois a formulação da estratégia acontece através de análise de fatos históricos nos ambientes interno e externo dentro de um horizonte definido. Os planejamentos 
estratégicos são voltados para períodos de cinco anos e são adaptados anualmente de acordo com mudanças de cenário.

O alinhamento entre a estratégia e a TI (HENDERSON \& VENKATRAMAN, 1993) é claramente de "Execução da Estratégia". A estratégia de negócio é preponderante na definição da estrutura organizacional, que por consequência, influencia a estrutura e os processos da TI. O grau de maturidade do alinhamento é de nível 1, inicial, o nível de alinhamento estratégico é baixo, sendo difícil alcançar bons resultados mesmo que os investimentos sejam significativos (LUFTMAN, 2003).

Esse modelo também influencia as atividades de DA, como a estrutura de negócios é bastante segmentada representando suas diferentes linhas de produto, isso também é representado nas implementações de DA que são feitas de forma independente para cada categoria de produtos, limitando uma visão única do consumidor da montadora. Tanto a operação quanto as atividades de controle dos sistemas de DA são descentralizadas na execução e no desenvolvimento (BUCHANAN \& LINOWES, 1980).

\subsubsection{Sistema de valor}

A TI ocupa papel relevante na integração do sistema de valor da indústria automobilística (PORTER, 2001). A integração com fornecedores se dá através de leilões virtuais e ferramentas de supply chain management que integram as informações de estoque da montadora com o sistema de gestão de seus fornecedores.

Dentro do modelo de espaços virtuais propostos por Anghern (1997), a empresa utilizou basicamente o Virtual Information Space (VIS) para oferecer informações sobre seus veículos, incluindo simulação de configurações, a fim de impulsionar as vendas.

O relacionamento com o consumidor poderia ser mais beneficiado pelo potencial de DA, porém as iniciativas de customer relationship management possuem uma interação baixa com as atividades de DA.

A virtualidade foi limitada tanto no âmbito da organização (VENKATRAMAN \& HENDERSON, 1998) como no desenvolvimento de produtos e serviços (MATTOS \& LAURINDO, 2008). 


\subsubsection{Modelos de criação de valor em e-business}

Dentro do modelo proposto por Amit \& Zott (2001) seria exagerado dizer que houve a criação de valor através do e-business. O único direcionador desse modelo que teve impacto relevante da presença online foi a maior eficiência, proporcionado pelo aplicativo de montagem do veículo que envia informações da intenção de compra para a concessionária mais próxima do consumidor.

\subsubsection{Co-criação de valor}

Não houve evidências de co-criação de valor através das informações de DA.

\subsubsection{Estratégia para mercados segmentados}

Não foram encontradas evidência de estratégias para mercados segmentados baseadas em DA.

\subsubsection{Gestão de negócios}

\subsubsection{Planejamento estratégico}

O planejamento estratégico foi pouco influenciado pelas informações de DA. O indicador de DA mais relevante para a estratégia da empresa é a audiência do site, pois as pesquisas de mercado indicam que a visita ao site possui forte influência na decisão de compra de um veículo. Por esse motivo, a empresa estabeleceu como meta, ser uma das líderes em audiência na web.

\subsubsection{Controle de qualidade}

A empresa possui sistemas de controle de qualidade e diversas certificações incluindo ISO-9000. Porém, não foi detectada nenhuma contribuição dos dados de DA para alimentação desses sistemas.

Também não foram identificadas práticas de sistemas de qualidade, como o ciclo Plan-Do-Check-Action (PDCA), na análise dos indicadores de DA.

\subsubsection{Gestão de conhecimento do consumidor}

As informações sobre a navegação dos consumidores ficam dispersas em diversos domínios de monitoramento. Os poucos relatórios de análise das mídias sociais e de performance de campanha são de períodos dispersos, prejudicando a gestão de conhecimento do consumidor. 


\subsubsection{Análise financeira}

Como dito no tópico de Otimização da Presença Online, a empresa raramente realiza estudos para avaliar o ROI. No entanto, numa das poucas vezes em que esse estudo foi realizado, notou-se impacto significativo da campanha nas vendas do veículo divulgado.

\subsubsection{Síntese do estudo de caso}

De forma geral a aderência à aplicação das variáveis do framework de DA foi fraca. Essa nota foi a mesma para todos os constructos: Capacidade analítica; contribuição da Internet para estratégia; e gestão de negócios (tabela 7.3).

A ausência de uma visual estratégica de DA impactou a forma como esse conceito foi implementado, minimizando os benefícios que DA poderia gerar para a organização. 
Tabela 7.3: Aderência das práticas da montadora às variáveis do framework de DA

\begin{tabular}{|c|c|c|c|}
\hline Constructos & Variáveis & Aderência & Justificativa \\
\hline \multirow[t]{6}{*}{$\begin{array}{l}\text { Capacidade } \\
\text { analítica }\end{array}$} & Inteligência competitiva & Razoável & $\begin{array}{l}\text { Pesquisas de mercado são acompanhadas, mas } \\
\text { são pouco utilizadas na formulação da estratégia. } \\
\text { Palavras-chave de de busca e mídias sociais não } \\
\text { são usados para inteligência competitiva }\end{array}$ \\
\hline & Otimização de presença ativa & Fraca & $\begin{array}{l}\text { Fragmentação do monitoramento dos resultados } \\
\text { da campanha. ROI de campanha raramente } \\
\text { calculado }\end{array}$ \\
\hline & Mídias sociais & Fraca & Apenas análises pontuais são realizadas \\
\hline & Usabilidade & Fraca & $\begin{array}{l}\text { Problema com indicadores prejudicam } \\
\text { monitoramento e implementação de melhorias }\end{array}$ \\
\hline & Convergência & Fraca & $\begin{array}{l}\text { Há potencial para integração de dados de ações } \\
\text { on e offline, mas há pouco cruzamento de } \\
\text { informações }\end{array}$ \\
\hline & Mediana do constructo & Fraca & \\
\hline \multirow[t]{6}{*}{$\begin{array}{l}\text { Contribuição da } \\
\text { Internet para } \\
\text { estratégia }\end{array}$} & $\begin{array}{l}\text { Alinhamento entre estratégia e } \\
\mathrm{TI}\end{array}$ & Fraca & $\begin{array}{l}\text { O alinhamento é de "Execução da Estratégia", } \\
\text { mas a maturidade é baixa e as estratégias são } \\
\text { específicas por linha de produto, prejudicando a } \\
\text { visão sobre consumidor }\end{array}$ \\
\hline & Mudanças no sistema de valor & Razoável & $\begin{array}{l}\text { Há bastante integração do sistema de valor } \\
\text { principalmente no lado do fornecedor, mas há } \\
\text { pouca mudança no relacionamento com } \\
\text { consumidores }\end{array}$ \\
\hline & $\begin{array}{l}\text { Modelos de criação de valor em } \\
\text { e-business }\end{array}$ & Fraca & $\begin{array}{l}\text { Houve ganho apenas no direcionador de } \\
\text { eficiência }\end{array}$ \\
\hline & Co-criação de valor & Muito fraca & Não houve evidências de co-criação de valor \\
\hline & $\begin{array}{l}\text { Estratégias para mercados } \\
\text { segmentados }\end{array}$ & Muito fraca & $\begin{array}{l}\text { Não foram encontradas evidência de estratégias } \\
\text { para mercados segmentados }\end{array}$ \\
\hline & Mediana do constructo & Fraca & \\
\hline \multirow[t]{5}{*}{ Gestão de negócios } & Planejamento estratégico & Fraca & $\begin{array}{l}\text { O planejamento estratégico foi pouco } \\
\text { influenciado pelas informações de DA }\end{array}$ \\
\hline & Controle da qualidade & Muito fraca & $\begin{array}{l}\text { Não houve impacto dos indicadores de DA na } \\
\text { Estratégia }\end{array}$ \\
\hline & $\begin{array}{l}\text { Gestão do conhecimento do } \\
\text { consumidor }\end{array}$ & Fraca & $\begin{array}{l}\text { Informações sobre o consumidor coletadas mas } \\
\text { são dispersas e não são utilizadas }\end{array}$ \\
\hline & Análise financeira & Fraca & ROI é raramente calculado \\
\hline & Mediana do constructo & Fraca & \\
\hline \multicolumn{2}{|c|}{ Aplicação de Digital Analytics } & Fraca & Potencial de uso de DA é subutilizado \\
\hline
\end{tabular}

\subsection{Estudo de caso C: Empresa do ramo de vestuário}

\subsubsection{Contexto da empresa}

\subsubsection{Informações sobre a indústria}

A indústria de vestuário é bastante dinâmica e competitiva, com forças bastante impactantes e atratividade reduzida, como pode ser visto na figura 7.3 (PORTER, 1979). Dentro desse cenário, surge a necessidade da empresa possuir vantagens competitivas bem definidas versus seus concorrentes. 


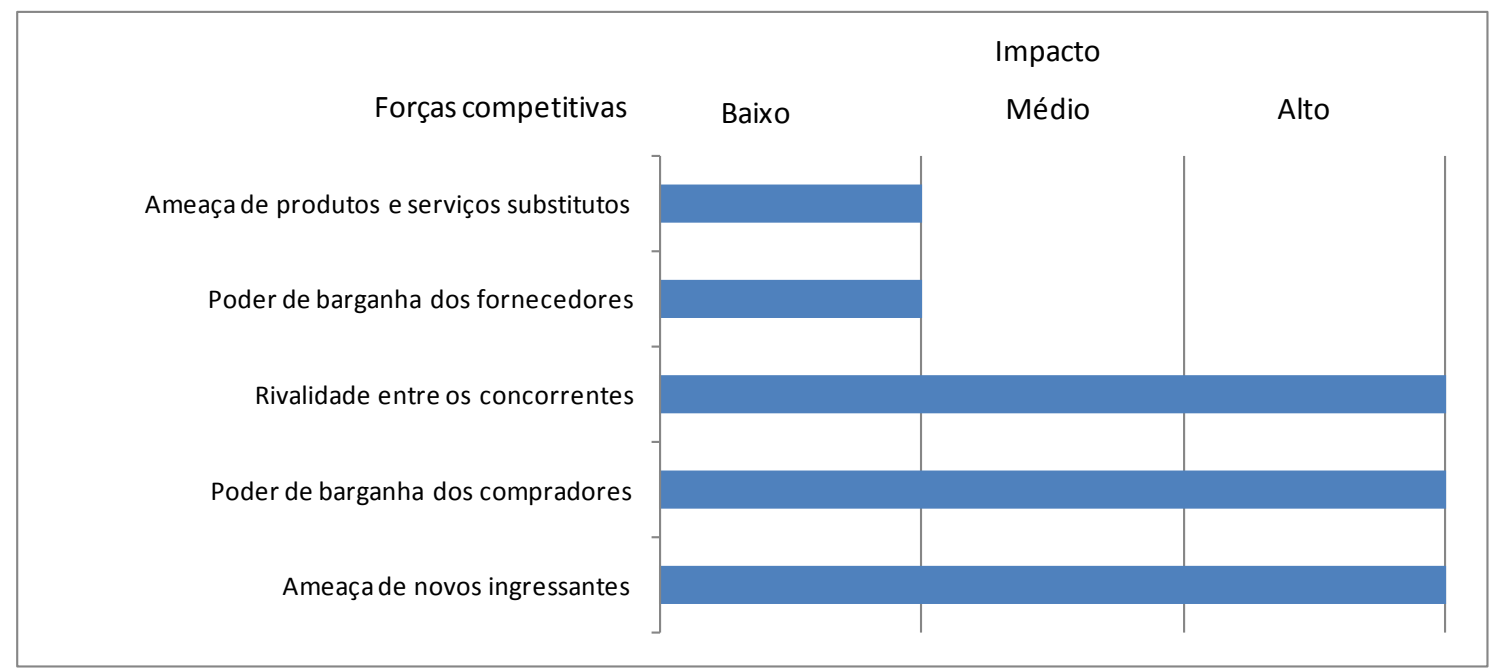

Figura 7.3: Impacto das forças competitivas para o mercado de vestuário (Elaborado pelo autor, baseado em Porter, 1979)

\subsubsection{Produtos e serviços da empresa}

As linhas de produto da empresa se resumem a apenas um item do vestuário, que não será revelado para preservar a confidencialidade da empresa. Esse item é oferecido em modelos, cores e estampas diferentes.

O produto é distribuído para diversos países do mundo e a marca é reconhecida internacionalmente.

\subsubsection{Estratégia genérica}

A estratégia genérica é de diferenciação, sendo que os principais atributos são a marca e a qualidade do produto final. A distribuição global do produto também é um fator crítico de sucesso, pois para disputar no mercado de moda, a empresa precisa ter uma marca não apenas reconhecida, mas usada em todo o mundo.

\subsubsection{Organização da tecnologia}

A estrutura de tecnologia é enxuta e a execução dos projetos de TI é terceirizada, assim como a manutenção dos sistemas necessários para gestão do negócio.

\subsubsection{Presença online}

O site da empresa possui modelo de navegação simples com design arrojado. Esse site é oferecido em diversos idiomas para atender a seus consumidores no mundo inteiro. Ele também possui uma loja online cuja plataforma é 
terceirizada, a empresa paga uma comissão a essa plataforma por venda realizada.

As opções pelo design arrojado, multilíngue e pela terceirização da loja revelam a estratégia da empresa baseada em diferenciação pela marca e foco nas atividades consideradas core business: acompanhar as tendências da moda e realizar a distribuição global do produto.

A empresa possui perfil nas mídias sociais para divulgação de informações institucionais, porém o detalhe mais relevante é que os próprios consumidores desenvolvem comunidades bastante ativas sobre a marca, chegando a criar aplicativos que são viralizados na rede.

\subsubsection{Estrutura e organização das atividades de DA}

O site possui rastreamento através do Google Analytics e as mídias sociais possuem monitoramento ad hoc de acordo com questões que são relevantes à marca em determinados momentos.

Não existe uma estrutura interna para realizar os estudos de DA, as análises são empreendidas por agências de publicidade e consultorias que avaliam a percepção e os atributos da marca, assim como a usabilidade do site.

\subsubsection{Competência analítica}

\subsubsection{Inteligência competitiva}

Nos estudos sobre a marca, são avaliadas as percepções sobre os produtos e marcas concorrentes. Mais importante do que questões quantitativas, os executivos de marketing da empresa procuram entender o que os consumidores comentam sobre as marcas globais. Esse monitoramento é pontual como será visto no tópico "Mídias Sociais".

Não há acompanhamento sistemático de pesquisas de mercado sobre audiência de sites concorrentes.

\subsubsection{Otimização da presença ativa}

A divulgação da marca da empresa se dá basicamente de forma espontânea, através da divulgação da marca por seus próprios usuários. Por esse motivo, as métricas de cobertura são entendidas como o alcance das comunidades através das diferentes comunidades espalhadas pela Internet. A percepção da 
marca e o grau de engajamento são indicadores críticos medidos de forma esporádica.

\subsubsection{Mídias sociais}

As mídias sociais são ponto crítico do monitoramento, pois se a marca é um dos diferenciais da empresa, entender o que essa marca representa para seus consumidores é chave para o sucesso. No entanto, as análises de mídias sociais são ad hoc e realizadas esporadicamente com o auxílio de empresas de pesquisa.

Uma dessas empresas mensurou o engajamento dos consumidores à marca classificando o relacionamento com o internauta em três níveis: membro de uma comunidade na Internet; pessoas que afirmam ser consumidoras do produto; e fanáticos pela marca, pessoas que criam e publicam vídeos sobre a marca e a defendem em fóruns na Internet (figura 7.4).

A percepção dos consumidores sobre a marca também foi captada através de pesquisa qualitativa baseada nos comentários postados nas mídias sociais e em vídeos publicados no Youtube. Através dessa pesquisa, pode-se perceber que fatores como o humor e sensualidade são identificados pelos usuários como atributos da marca como pode ser visto no mapa mental onde o tamanho da fonte é proporcional ao número de publicações sobre o tema (figura 7.5).

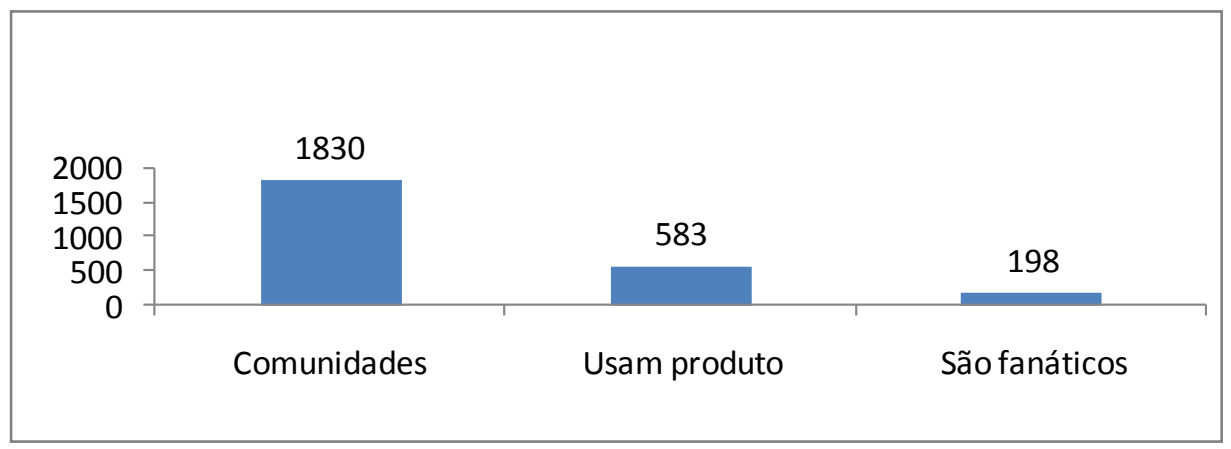

Figura 7.4: Engajamento à marca (mil usuários) 


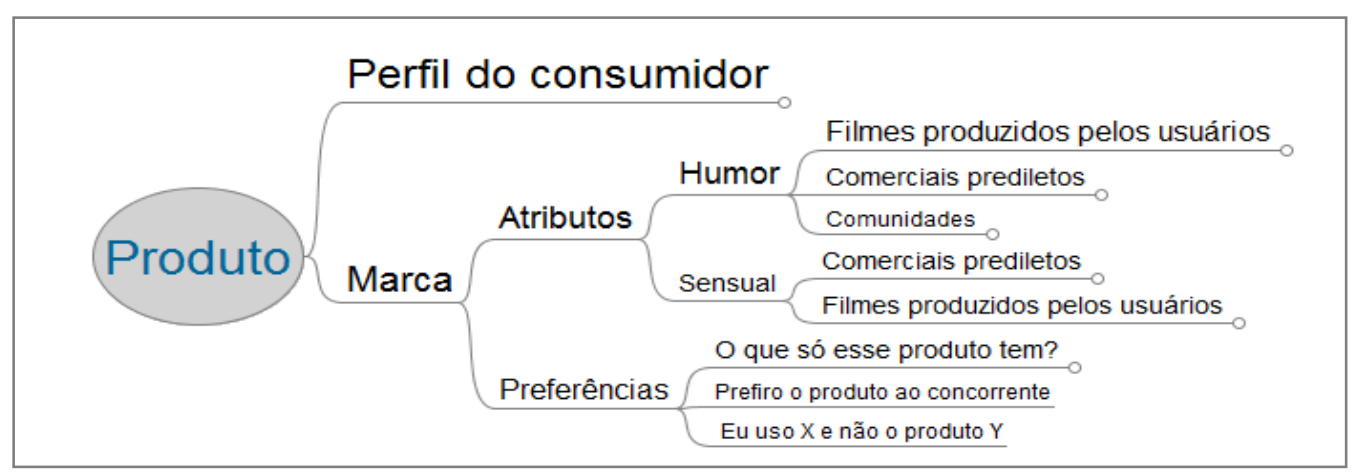

Figura 7.5: Mapa mental sobre percepção da marca

\subsubsection{Usabilidade}

Uma questão importante é entender a experiência do consumidor com a marca nos ambientes online. Alguns indicadores de usabilidade são críticos nessa experiência como o tempo de navegação no site e o bounce rate, que é a taxa de abandono do site logo na primeira página visualizada pelo internauta.

Um fator que incomodava aos executivos era o alto bounce rate no site, uma análise mais aprofundada mostrou que esse problema ocorria principalmente com os visitantes de outros países. Nota-se que os internautas provenientes de países como Estados Unidos, Filipinas e Japão abandonavam o site na primeira pagina e ficavam muito pouco tempo no site (figura 7.6).

Estudos de usabilidade mostraram que os internautas tinham dificuldade para localizar o link para ver o site em outros idiomas devido ao design fora dos padrões. Uma breve modificação na home foi suficiente para corrigir essa falha e tornar a navegação mais proveitosa ao público internacional. 


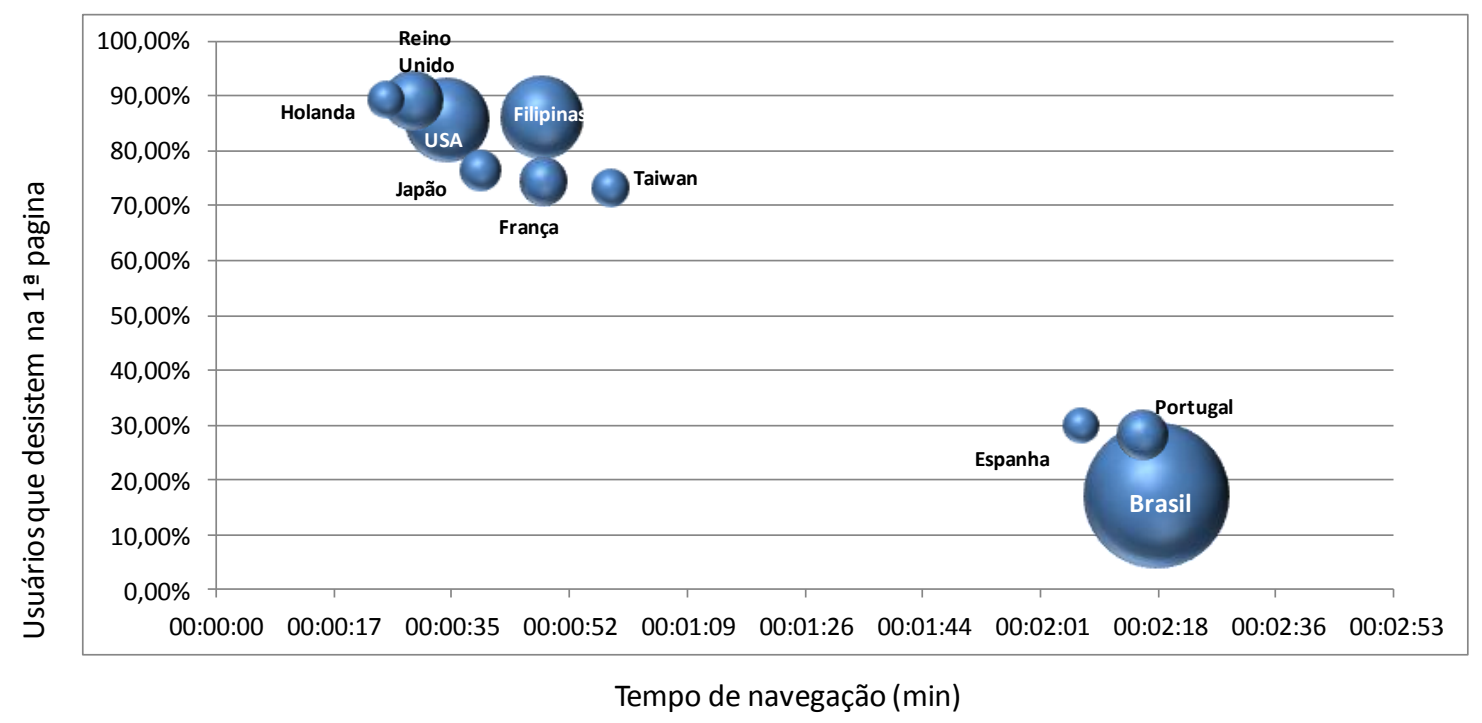

Figura 7.6: Hábitos de navegação no site por país

\subsubsection{Convergência}

Não foram encontradas evidências de efeitos que DA tenha causado nas ações offline da empresa e vice-versa.

\subsubsection{Contribuições da Internet para estratégia}

\subsubsection{Alinhamento entre estratégia e TI}

A visão estratégica preponderante na empresa é baseada no Empreendedorismo, olha-se para o futuro distante, na busca de uma visão única (MINTZBERG \& LAMPEL,1999). Prova disso é a disseminação da marca em todo mundo baseada numa visão de marketing arrojada dos executivos.

$\mathrm{O}$ alinhamento entre estratégia e TI seguiu um modelo de "Execução da Estratégia" (HENDERSON \& VENKATRAMAN, 1993). Isso impacta na forma como DA é realizado, pois há um peso maior para gestão da marca que é crítica para empresa. Análise que poderiam levar a criação de novas linhas de produto ou até mesmo a novos usos não foram priorizadas, limitando o potencial de inovação trazido por DA. O grau de maturidade desse alinhamento é baixo, nível 1 (LUFTMAN, 2003).

Todas as atividades de DA, sejam de controle como de execução são terceirizadas. 


\subsubsection{Sistema de valor}

A Internet ampliou a presença da empresa no Virtual Information Space (VIS) e no Virtual Communication Space (VCS) (ANGHERN, 1997) ampliando a divulgação das informações para públicos em diversos países e proporcionando um novo meio de comunicação com os consumidores nas mídias sociais.

A presença online é importante para que os executivos consigam entender melhor o perfil do consumidor e suas necessidades em diferentes países, dessa forma, contribui para estreitar os laços com esses mercados. No entanto, não foram detectados sinais de uma integração mais intensa do sistema de valor (PORTER, 1979) nem de criação de redes de valor (BOVET \& MARTHA, 2001).

A virtualidade afeta pouco a organização (VENKATRAMAN \& HENDERSON, 1998) e o desenvolvimento de novos produtos (MATTOS \& LAURINDO, 2008).

\subsubsection{Modelos de criação de valor em e-business}

Dentre os direcionares de criação de valor propostos por Amit \& Zott (2001), pode-se dizer que o mais aderente à presença online da empresa é a fidelização, pois foram realizadas ações para entender melhor o consumidor e incrementar a experiência deles com a marca.

\subsubsection{Co-criação de valor}

Através da análise das mídias sociais, a empresa conseguiu entender como o consumidor usa seu produto, os tipos de combinações com outras peças do vestuário e em que tipos de ocasiões o produto é utilizado. Esse entendimento dos consumidores cria espaço para que a empresa elabore novos produtos e melhore seus serviços. Porém, esse potencial não está sendo plenamente aproveitado no momento.

\subsubsection{Estratégia para mercados segmentados}

A análise do comportamento dos consumidores em cada país é uma base de conhecimento para estratégias regionais. No entanto, essas informações foram utilizadas apenas para finalidades táticas como a melhora na navegação no site. 


\subsubsection{Gestão de negócios}

\subsubsection{Planejamento estratégico}

A contribuição dos indicadores de DA para o planejamento estratégico foram as análises de engajamento e de percepção de marca nas mídias sociais. Esses estudos comprovaram o reconhecimento da marca em outros países e mostraram a disposição do usuário em criar um vínculo com a marca em comunidades e discutir usos e aplicações do produto.

\subsubsection{Controle de qualidade}

A empresa possui sistema de controle da qualidade limitado à fábrica de seus produtos. Os indicadores de DA não fazem parte desses sistemas.

\subsubsection{Gestão de conhecimento do consumidor}

Os dados sobre hábitos dos consumidores são armazenados nas ferramentas de monitoramento da audiência e em relatórios produzidos pelas consultorias. Mas não há processos para gestão do conhecimento e disseminação dessa informação.

\subsubsection{Análise financeira}

O ROI sobre a presença online não é monitorado pelos executivos, acredita-se que isso se deva ao baixo investimento das ações na Internet.

\subsubsection{Síntese do estudo de caso}

De forma geral, a aderência da empresa às variáveis do framework de DA é razoável (figura 7.4). A empresa conseguiu melhorar a experiência do consumidor no site e entendeu seu comportamento nas mídias sociais. Embora a empresa tenha vislumbrado o comportamento do consumidor nas mídias sociais, esse estudo serviu apenas como uma pesquisa sobre a marca. Outras aplicações como a utilização das opiniões do consumidor para criação de novos produtos e a definição de estratégia para mercados segmentados não foram exploradas. Assim como foi muito fraca a aplicação de conceitos de gestão de negócios. 


\subsection{Estudo de caso D: Fabricante de bebidas}

\subsubsection{Contexto da empresa}

\subsubsection{Informações sobre a indústria}

A indústria de bebidas não alcoólicas no Brasil é influenciada por tendências de aumento de renda da população e ascensão da classe C. Entre 2005 e 2010, o consumo dessas bebidas per capita passou de 168,4 litros para 206,7 litros, um crescimento de $22,7 \%$ (ABIR, 2011).

Tabela 7.4: Aderência das práticas da empresa de vestuário às variáveis do framework de DA

\begin{tabular}{|c|c|c|c|}
\hline Constructos & Variáveis & Aderência & Justificativa \\
\hline \multirow[t]{6}{*}{$\begin{array}{l}\text { Capacidade } \\
\text { analítica }\end{array}$} & Inteligência competitiva & Fraca & $\begin{array}{l}\text { O mercado é monitorado esporadicamente, através de } \\
\text { mídias sociais. Não há estudos quantitativos. }\end{array}$ \\
\hline & Otimização de presença ativa & Fraca & $\begin{array}{l}\text { Presença ativa fortemente baseada em mídias sociais, } \\
\text { mas indicadores críticos são pouco monitorados }\end{array}$ \\
\hline & Mídias sociais & Forte & Empresa mensura engajamento e atributos da marca \\
\hline & Usabilidade & Forte & $\begin{array}{l}\text { Indicadores monitorados e melhoria do site com razoável } \\
\text { impacto na experiência do usuário }\end{array}$ \\
\hline & Convergência & Muito fraca & $\begin{array}{l}\text { Não foram encontradas evidências de efeitos que DA } \\
\text { tenha causado nas ações offline da empresa e vice-versa }\end{array}$ \\
\hline & Mediana do constructo & Fraca & \\
\hline \multirow{6}{*}{$\begin{array}{l}\text { Contribuição } \\
\text { da Internet } \\
\text { para estratégia }\end{array}$} & Alinhamento entre estratégia e TI & Fraca & $\begin{array}{l}\text { Alinhamento de "Execução da Estratégia" com baixo grau } \\
\text { de maturidade. Baixo impacto na aplicação de DA }\end{array}$ \\
\hline & Mudanças no sistema de valor & Razoável & $\begin{array}{l}\text { Há melhor relacionamento com o consumidor, porém } \\
\text { com pouca integração do sistema de valor }\end{array}$ \\
\hline & $\begin{array}{l}\text { Modelos de criação de valor em } \\
\text { e-business }\end{array}$ & Fraca & $\begin{array}{l}\text { O único direcionador de criação de valor mais evidente é } \\
\text { a fidelização impactada pelo melhor relacionamento com } \\
\text { o consumidor }\end{array}$ \\
\hline & Co-criação de valor & Razoável & $\begin{array}{l}\text { O melhor entendimento do consumidor pode influenciar } \\
\text { o desenvolvimento de novos produtos }\end{array}$ \\
\hline & $\begin{array}{l}\text { Estratégias para mercados } \\
\text { segmentados }\end{array}$ & Fraca & $\begin{array}{l}\text { O conhecimento do comportamento do consumidor em } \\
\text { vários países foi pouco utilizado na elaboração de } \\
\text { estratégias segmentadas }\end{array}$ \\
\hline & Mediana do constructo & Fraca & \\
\hline \multirow[t]{5}{*}{$\begin{array}{l}\text { Gestão de } \\
\text { negócios }\end{array}$} & Planejamento estratégico & Razoável & $\begin{array}{l}\text { Indicadores de DA foram relevantes para entender } \\
\text { vínculo do consumidor com a marca }\end{array}$ \\
\hline & Controle da qualidade & Muito Fraca & $\begin{array}{l}\text { Os indicadores de DA não fazem parte dos sistemas de } \\
\text { controle da qualidade }\end{array}$ \\
\hline & $\begin{array}{l}\text { Gestão do conhecimento do } \\
\text { consumidor }\end{array}$ & Fraca & $\begin{array}{l}\text { Apesar de haver dados sobre consumidores serem } \\
\text { armazenados, não há processos para gestão do } \\
\text { conhecimento e disseminação dessa informação }\end{array}$ \\
\hline & Análise financeira & Muito fraca & Não são realizadas análises de ROI para ações online \\
\hline & Mediana do constructo & Fraca & \\
\hline \multicolumn{2}{|c|}{ Aplicação de Digital Analytics } & Fraca & $\begin{array}{l}\text { Embora haja potencial interessante de impacto das } \\
\text { análises de DA, elas são esporádicas e pouco integradas } \\
\text { aos processos da empresa }\end{array}$ \\
\hline
\end{tabular}

O setor é bastante competitivo, com forças impactantes relacionadas à ameaça de novos ingressantes, rivalidade entre os concorrentes e poder de barganha dos compradores, como pode ser visualizado na figura 7.7.

\subsubsection{Produtos e serviços da empresa}


A empresa fornece uma série de produtos dentro do segmento de não alcoólicos. Os produtos são distribuídos nacionalmente e cada linha possui uma estratégia mercadológica distinta. A linha de produtos de refrigerantes será o foco desse estudo.

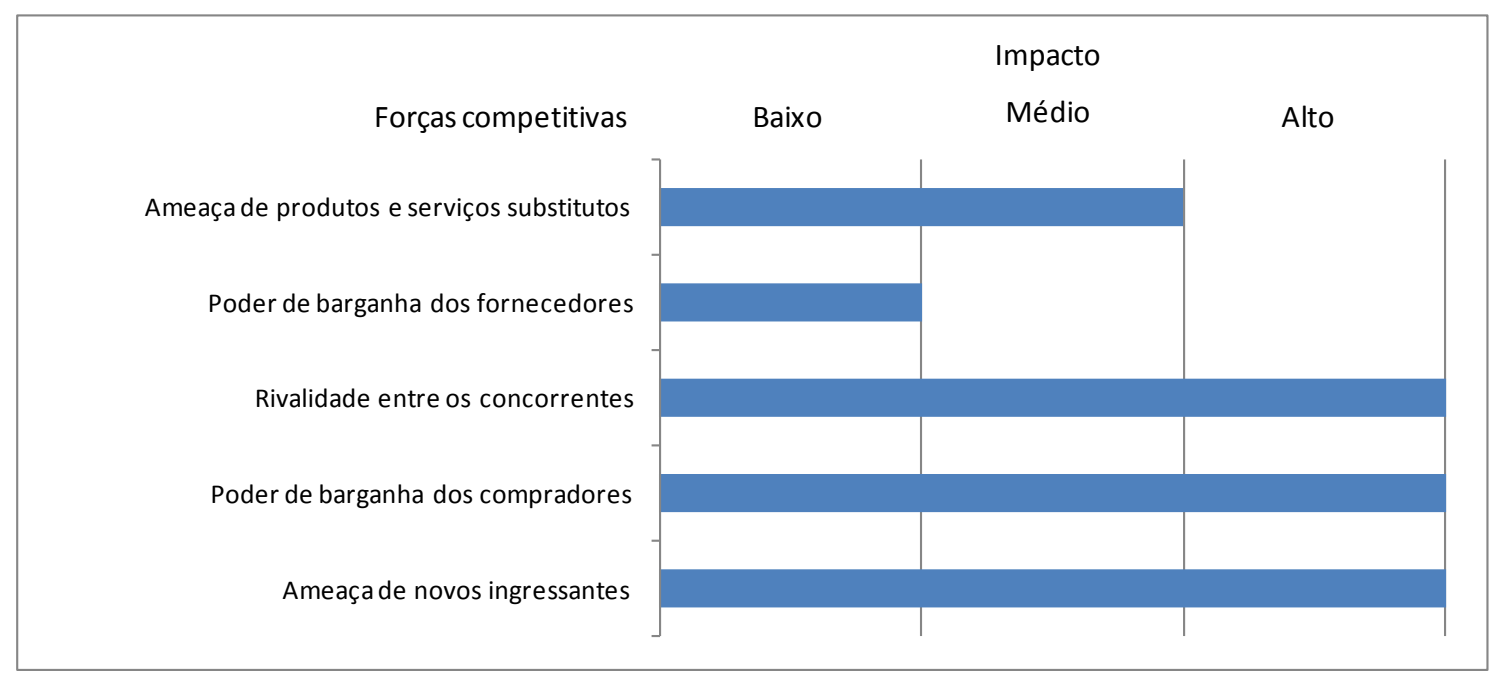

Figura 7.7: Impacto das forças competitivas para o mercado de bebidas não alcoólicas

(Elaborado pelo autor, baseado em Porter, 1979)

\subsubsection{Estratégia genérica}

A estratégia genérica é de diferenciação. Os atributos chave são a marca, a qualidade do produto e a distribuição.

\subsubsection{Organização da tecnologia}

A produção das bebidas é distribuída, havendo diversas fábricas espalhadas pelo território nacional de acordo com a demanda de cada região. As atividades de apoio são centralizadas para otimização dos custos. As decisões relacionadas à tecnologia, como a escolha de pacotes de ERP são centralizadas, embora haja estruturas dedicadas a cada operação.

O desenvolvimento e a manutenção dos sites é completamente terceirizado, sendo que a contratação e gestão desses serviços fica a critério do departamento de marketing.

\subsubsection{Presença online}

A empresa possui sites para cada marca de refrigerantes que comercializa. $O$ design do site segue a identidade visual de cada marca. Em geral os sites são bastante interativos, havendo espaço para o consumidor enviar receitas, 
participar de jogos e postar comentários. Esses comentários possuem alguma moderação, sendo vetados termos como marcas concorrentes e palavrões.

Eventualmente, são desenvolvidos sites temporários, hotsites, para apoiar promoções e eventos.

\subsubsection{Estrutura e organização das atividades de DA}

Todos os sites possuem monitoramento através de Google Analytics e uma ferramenta customizada, a duplicidade de ferramentas serve para auditoria dos resultados de audiência e também como backup, caso uma das ferramentas não funcione, não se perdem os dados de audiência do período.

Os indicadores de campanhas de mídia são monitorados através de ferramentas de ad server e as mídias sociais são analisadas através de uma consultoria especializada que fornece relatórios periódicos.

\subsubsection{Competência analítica}

\subsubsection{Inteligência competitiva}

A inteligência competitiva é uma habilidade relevante nessa indústria bastante competitiva. A empresa analisa com profundidade as pesquisas de mercado através de um painel mensal, onde são comparados os seguintes indicadores com a concorrência: audiência do site; tempo de navegação, páginas vistas por usuário.

As mídias sociais são monitoradas através de relatórios semanais onde são avaliados: o volume de comentários em mídias sociais das marcas da empresa e dos principais concorrente; a "análise de sentimentos" desses comentários, classificando-os em positivos, negativos ou neutros; os influenciadores, que são os internautas cujos comentários causam a maior repercussão (LIMA et al., 2005).

As palavras-chave digitadas pelo consumidor para se chegar aos sites das marcas também são analisadas proporcionando alguns insights inusitados. Percebeu-se que uma das marcas tinha uma grafia difícil para os consumidores, o que gerava problemas quando as pessoas tentavam digitar 0 endereço do site. Esse problema foi contornado com a compra de links patrocinados das palavras-chave contendo a grafia equivocada.

Otimização da presença ativa 
A empresa realiza uma série de campanhas para suas marcas, chegando a lançar mais de uma campanha por mês. Essas campanhas possuem paralelo na presença online seja através de mídia online em portais e mecanismos de busca, através da criação de hotsites ou áreas no site para receber os consumidores impactados pelas campanhas, ou até mesmo, através de interações com os consumidores através das mídias sociais.

O espectro de indicadores é bem complexo, indo do controle da cobertura até a mensuração do custo por visita. Havendo esforços de otimização que reduzem expressivamente o custo das campanhas.

\subsubsection{Mídias sociais}

Com dito no tópico de "Competência Analítica" a empresa monitora sistematicamente as mídias sociais para avaliar os sentimentos dos consumidores pela marca. Essa análise é importante para gerenciar eventuais crises com os consumidores. Numa oportunidade, houve mudança no design de uma das marcas da empresa. Essa mudança foi feita globalmente e havia uma campanha planejada para lançamento da nova marca no Brasil. Porém, alguns designers e publicitários passaram a criticar a nova marca em redes sociais afirmando que a marca não tinha personalidade, uma vez que ela mudava de acordo com o sabor do refrigerante.

Ao ter acesso a essa análise, a assessoria de imprensa da empresa entrou em contato com os críticos mais influentes e montou um evento onde foi explicado o conceito da marca e que a variação do design era associada a uma ideia de desconstrução da marca, que mantém os atributos originais, mas que se adapta ao contexto, no caso a embalagem de cada sabor.

Após esse evento, os influenciadores passaram a publicar comentários positivos, explicando o novo conceito e contribuindo para o sucesso da campanha.

\subsubsection{Usabilidade}

A empresa acompanha a evolução dos indicadores de usabilidade do site como tempo de navegação, bounce rate, e taxa de retorno ao site mensalmente. Esses indicadores são discutidos com a agência responsável pelo desenvolvimento dos sites e, eventualmente, geram melhorias no site. 
De forma geral, são privilegiados os espaços para campanhas e a home do site fica um pouco confusa, prejudicando a navegação dos usuários.

\subsubsection{Convergência}

Esporadicamente, os estudos de DA servem para avaliar ações offline da empresa. Algumas ações em pontos de venda e eventos promovidos pela marca tiveram impacto nas mídias sociais, e por esse motivo, foram detectados por DA.

\subsubsection{Contribuições da Internet para estratégia}

\subsubsection{Alinhamento entre estratégia e TI}

A escola de formulação de estratégia da empresa é de posicionamento, a formulação da estratégia acontece através de análise de fatos históricos dentro de um horizonte definido (MINTZBERG \& LAMPEL,1999).

O modelo de alinhamento estratégico é de "Execução da Estratégia" (HENDERSON \& VENKATRAMAN, 1993), a presença está a serviço da gestão da marca que é um dos ativos importantes para a competição. Esse alinhamento permeia todos os indicadores de DA. O nível de alinhamento é de processos estabilizados, nível 3.

O controle e a execução das atividades relacionadas aos sistemas de DA são descentralizadas e terceirizadas (BUCHANAN \& LINOWES, 1980).

\subsubsection{Sistema de valor}

Houve alteração no vínculo com os consumidores, o relacionamento que era intermediado pelos pontos de venda, passou a ser direto através do site. $\mathrm{O}$ entendimento do consumidor, que era feito através de surveys e grupos focais, foi ampliado para um monitoramento quase em tempo real das mídias sociais, tornando mais dinâmica à tomada de decisões como no caso da gestão de crise devido ao novo desenho da marca. Pode-se dizer que a presença online expandiu o espaço tradicional do mercado através do Virtual Information Space (VIS) e do Virtual Communication Space (VCS) (ANGHERN, 1997). A virtualidade afetou ligeiramente a organização (VENKATRAMAN \& HENDERSON, 1998) e a criação de novos usos, receitas, para os seus produtos e serviços (MATTOS \& LAURINDO, 2008). 


\subsubsection{Modelos de criação de valor em e-business}

Considerando os direcionadores de criação de valor propostos por Amit \& Zott (2001), pode-se dizer que houve uma contribuição razoável de DA:

- A eficiência das campanhas foi aumentada através da redução nos custos por clique;

- Os estudos em mídias sociais serviram para subsidiar a empresa em momentos de inovação, como a mudança na marca e o lançamento de novos sabores;

- A fidelização foi impactada pelo melhor entendimento da satisfação do consumidor através das mídias sociais;

- A complementaridade foi incrementada através da oferta de receitas que sugeriam novos usos aos produtos da marca.

\subsubsection{Co-criação de valor}

Conforme descrito nos outros tópicos, DA foi importante para avaliar opinião dos consumidores nos momentos em que a empresa introduziu inovações na marca e nos produtos.

\subsubsection{Estratégia para mercados segmentados}

Não foram detectadas evidências de DA como suporte à elaboração de estratégias para mercados segmentados.

\subsubsection{Gestão de negócios}

\subsubsection{Planejamento estratégico}

Alguns indicadores de DA foram considerados no planejamento estratégico para avaliar a percepção dos consumidores. A presença online e, por consequência, os indicadores de DA foram importantes para execução da estratégia da empresa.

\subsubsection{Controle de qualidade}

Pode-se dizer que o ciclo PDCA foi relevante para melhorar a experiência do consumidor na Internet. Mas não houve contribuição dos indicadores de DA para os sistemas de qualidade da empresa.

\subsubsection{Gestão de conhecimento do consumidor}


Os insights gerados por DA foram disseminados ocasionalmente por outras áreas da empresa. As pessoas responsáveis pela presença online acompanhavam todos os relatórios, mas a comunicação interna dos mesmos era falha. As outras áreas da empresa eram envolvidas em momentos de gestão de crise ou quando os gerentes de produto solicitavam informações sobre a percepção dos consumidores. Não há procedimento para armazenamento das informações, o que torna as análises bastante dependentes das pessoas envolvidas.

\subsubsection{Análise financeira}

A empresa preocupou-se com os indicadores financeiros. Assim como é um objetivo estratégico aproximar o relacionamento com os consumidores, também é fundamental reduzir os custos com a comunicação. A empresa conseguiu aumentar a audiência de seus sites e melhorar a experiência de navegação reduzindo pela metade o custo por clique. Exemplo raro de eficiência com eficácia (LAURINDO, 2008) na presença online.

\subsubsection{Síntese do estudo de caso}

As práticas da empresa do estudo de caso $D$ possuem aderência forte às variáveis de DA. Pode-se notar no caso um exemplo de como utilizar os indicadores de DA para execução da estratégia, usando a presença online para apoiar e melhorar o relacionamento com os consumidores.

\subsection{Estudo de caso E: Editora de livros didáticos}

\subsubsection{Contexto da empresa}

\subsubsection{Informações sobre a indústria}

O mercado de livros no Brasil movimentou cerca de 1,4 bilhão de reais em 2010 (ABRELIVROS, 2011). 90\% dessas vendas foram para o segmento de livros didáticos, sendo que apenas o governo é responsável por mais da metade das compras desse segmento.

O impacto das forças competitivas (PORTER, 1979) é razoável e bem distribuído, conforme pode ser notado na figura 7.8. Com destaque para a ameaça de novos entrantes, facilitada, sobretudo, pela digitalização dos meios 


\section{de produção que tornaram o processo editorial mais barato e facilitaram a entrada de novos competidores.}

Tabela 7.5: Aderência das práticas da empresa de bebida às variáveis do framework de DA

\begin{tabular}{|c|c|c|c|}
\hline Constructos & Variáveis & Aderência & Justificativa \\
\hline \multirow[t]{6}{*}{$\begin{array}{l}\text { Capacidade } \\
\text { analítica }\end{array}$} & Inteligência competitiva & Muito forte & $\begin{array}{l}\text { Acompanhamento sistemático da presença online dos } \\
\text { concorrentes e das tendências do mercado }\end{array}$ \\
\hline & Otimização de presença ativa & Muito forte & $\begin{array}{l}\text { Indicadores de desempenho completos e monitorados } \\
\text { continuamente causando redução de custos }\end{array}$ \\
\hline & Mídias sociais & Forte & $\begin{array}{l}\text { Monitoradas sistematicamente, com impacto na gestão } \\
\text { de crises }\end{array}$ \\
\hline & Usabilidade & Razoável & $\begin{array}{l}\text { Indicadores são acompanhados, mas as melhorias são } \\
\text { eventuais }\end{array}$ \\
\hline & Convergência & Fraca & Baixa convergência entre ações on e offline \\
\hline & Mediana do constructo & Forte & \\
\hline \multirow{6}{*}{$\begin{array}{l}\text { Contribuição } \\
\text { da Internet } \\
\text { para estratégia }\end{array}$} & Alinhamento entre estratégia e $\mathrm{TI}$ & Muito forte & $\begin{array}{l}\text { O alinhamento de "Execução da Estratégia" molda a } \\
\text { forma como as estratégias de DA são realizadas }\end{array}$ \\
\hline & Mudanças no sistema de valor & Forte & $\begin{array}{l}\text { A presença online expandiu o espaço tradicional do } \\
\text { mercado através da virtualidade }\end{array}$ \\
\hline & $\begin{array}{l}\text { Modelos de criação de valor em } \\
\text { e-business }\end{array}$ & Muito forte & $\begin{array}{l}\text { Houve criação de valor através dos direcionadores: } \\
\text { eficiência, complementaridade, inovação e fidelização }\end{array}$ \\
\hline & Co-criação de valor & Forte & $\begin{array}{l}\text { DA foi importante para avaliar opinião dos consumidores } \\
\text { na introdução de inovações na marca e nos produtos }\end{array}$ \\
\hline & $\begin{array}{l}\text { Estratégias para mercados } \\
\text { segmentados }\end{array}$ & Muito fraca & $\begin{array}{l}\text { Não foram detectadas evidências de DA como suporte à } \\
\text { elaboração de estratégias para mercados segmentados }\end{array}$ \\
\hline & Mediana do constructo & Forte & \\
\hline \multirow[t]{5}{*}{$\begin{array}{l}\text { Gestão de } \\
\text { negócios }\end{array}$} & Planejamento estratégico & Forte & $\begin{array}{l}\text { Alguns indicadores de DA foram usados no planejamento } \\
\text { estratégico para avaliar a percepção dos consumidores }\end{array}$ \\
\hline & Controle da qualidade & Muito fraca & $\begin{array}{l}\text { Não houve contribuição dos indicadores de DA para os } \\
\text { sistemas de qualidade da empresa }\end{array}$ \\
\hline & $\begin{array}{l}\text { Gestão do conhecimento do } \\
\text { consumidor }\end{array}$ & Razoável & $\begin{array}{l}\text { Relatórios de DA são acompanhados por especialistas, } \\
\text { mas disseminação da informação entre áreas de negócios } \\
\text { é falha }\end{array}$ \\
\hline & Análise financeira & Muito forte & $\begin{array}{l}\text { A empresa conseguiu aumentar a audiência de seus sites } \\
\text { e melhorar a experiência de navegação reduzindo pela } \\
\text { metade o custo por clique }\end{array}$ \\
\hline & Mediana do constructo & Forte & \\
\hline \multicolumn{2}{|c|}{ Aplicação de Digital Analytics } & Forte & $\begin{array}{l}\text { A empresa fez bom uso de DA para atingir seus objetivos } \\
\text { estratégicos }\end{array}$ \\
\hline
\end{tabular}




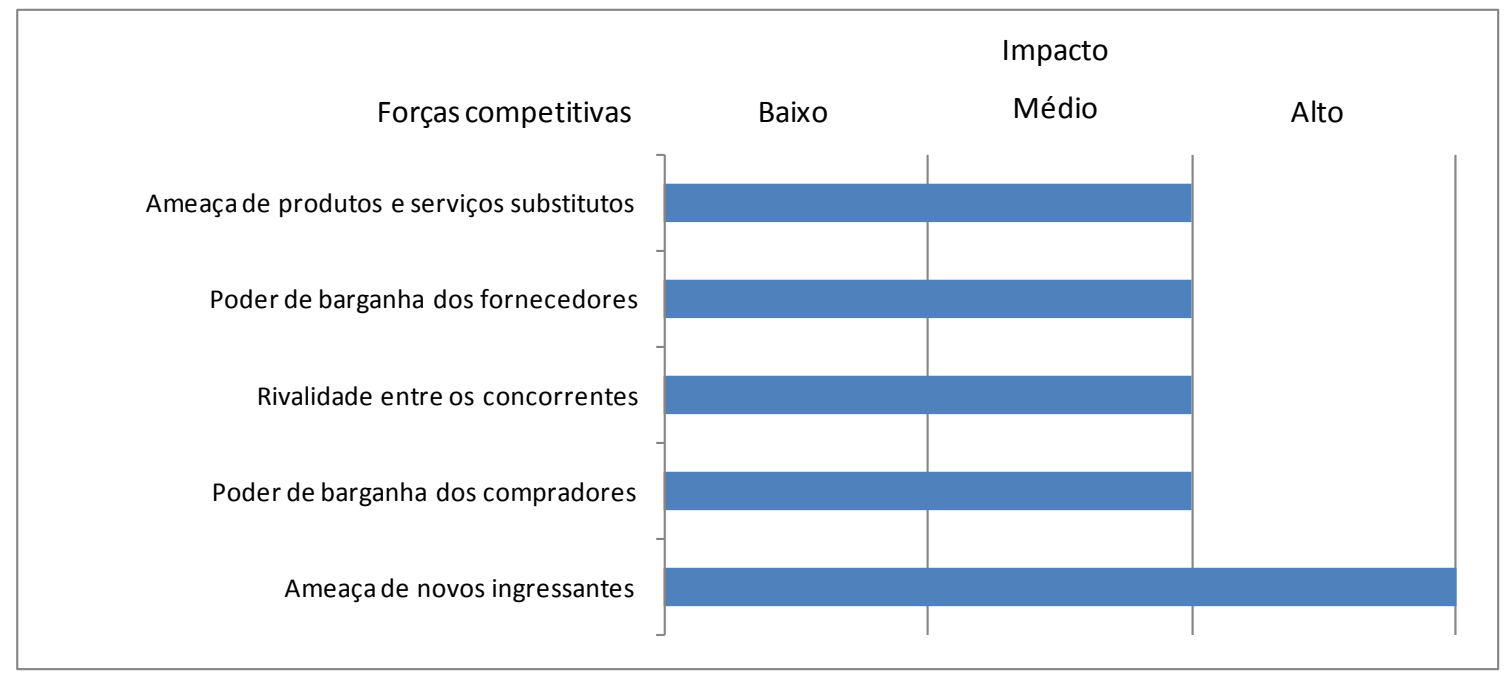

Figura 7.8: Impacto das forças competitivas para o mercado de livros didáticos (Elaborado pelo autor, baseado em Porter, 1979)

\subsubsection{Produtos e serviços da empresa}

A editora analisada possui uma série de selos agregados à sua marca que abrangem literatura, obras de referência, livros didáticos e sistemas de ensino. Os sistemas de ensino são livros didáticos, apostilas de exercício e material de apoio ao professor que seguem um programa pedagógico sugerido às escolas que adotam o material. Esses sistemas sugiram inicialmente a partir de cursos pré-vestibulares, foram disseminados no ensino médio e podem ser encontrados em todos os ciclos atualmente.

A análise desse estudo de caso será focada na unidade de negócio responsável pela produção e comercialização desses sistemas.

\subsubsection{Estratégia genérica}

A estratégia genérica é de diferenciação. Os fatores críticos de sucesso são a qualidade do conteúdo, a flexibilidade, os serviços pedagógicos de apoio e a distribuição em todo o território nacional. A flexibilidade é importante na elaboração do conteúdo programático para cada escola, de acordo com a necessidade, a editora pode mudar a ordem dos capítulos, suprimir e até adicionar conteúdos.

\subsubsection{Organização da tecnologia}


Todas as unidades de negócio compartilham uma estrutura centralizada de TI. Quase todas as atividades do departamento de TI são terceirizadas. Boa parte dos funcionários das empresas terceirizadas são ex-funcionários da editora e preservam parte relevante dos conhecimentos.

\subsubsection{Presença online}

O site da unidade de negócios faz a divulgação sistema de ensino na área aberta.

$\mathrm{Na}$ área restrita, são oferecidos os seguintes serviços para as escolas que adotaram o sistema:

- Download do material de apoio em formato digital;

- Solicitação de material físico (livros e apostilas);

- Atendimento ao professor;

- Acesso a vídeos com resolução de exercícios;

- Animações pedagógicas (ex.: experimentos de química);

- Portal educativo, espécie de versão de ferramentas de e-learning com conteúdos pré-configurados.

\subsubsection{Estrutura e organização das atividades de DA}

O site possui é monitorado através do Google Analytics e também possui uma ferramenta de monitoramento da área restrita que controla as interações de cada escola, o número de ações realizadas e quem acessou cada material.

Não há funcionários dedicados ao monitoramento, essa função é realizada pelas equipes comercial, de serviços e editorial de acordo com suas necessidades. Eventualmente, alguns relatórios são compartilhados com fornecedores quando esses são responsáveis pela produção de conteúdo.

\subsubsection{Competência analítica}

\subsubsection{Inteligência competitiva}

O uso de pesquisas de mercado é restrito nesse segmento, pois os sites não possuem uma audiência relevante para serem acompanhados através de painéis de pesquisas de mercado de empresas como o lbope e o ComScore. A análise dos concorrentes é feita através de comparativos obtidos através da visita ao site de outras editoras, feita esporadicamente. 
Não é feito controle das palavras-chave que o visitante digitou chegar ao site, nem dos comentários feitos em redes sociais.

Otimização da presença ativa

Os indicadores acompanhados pelos executivos da Editora são relacionados a audiência do site e as ações que o usuário realiza, como downloads e pedido de material. Não há métricas específicas para presença ativa.

\subsubsection{Mídias sociais}

Não são realizados estudos dos comentários do consumidor em redes sociais.

\subsubsection{Usabilidade}

Embora os indicadores de usabilidade sejam básicos, como número de visitas, conteúdo mais acessado e page-views, os conteúdos publicados no site sofrem influência da análise de conteúdos mais buscados. E quando são realizadas mudanças no site, a análise de usabilidade é considerada.

\subsubsection{Convergência}

Como exemplo de convergência, pode ser citado o número de acessos por escola como sinal de que o material está sendo usado em sua totalidade. Um baixo número de acessos pode ser indício de que a escola não está mais usando o material contratado e deseja rescindir o contrato. Com base nessa informação, a equipe comercial pode se antecipar e procurar entender os motivos de insatisfação antes do rompimento.

\subsubsection{Contribuições da Internet para estratégia}

\subsubsection{Alinhamento entre estratégia e TI}

A escola de formulação da estratégia é de posicionamento (MINTZBERG \& LAMPEL, 1999).

O modelo de alinhamento estratégico é de "Execução da Estratégia" (HENDERSON \& VENKATRAMAN, 1993), a presença online visa atender aos seguintes objetivos estratégicos: estabelecer um vínculo mais próximo com as escolas e diminuir os custos para atendimento às escolas. O grau de maturidade desse alinhamento é baixo, nível 1.

As atividades de controle e execução dos sistemas de DA são centralizadas (BUCHANAN \& LINOWES, 1980). 


\subsubsection{Sistema de valor}

A unidade de negócios conseguiu se relacionar melhor com as escolas através do site. As escolas por sua vez, podem usar o site para publicar material e notas para seus alunos, assim como usar o conteúdo pedagógico produzido pelos autores e fornecedores especializados. Toda essa interação pode ser mensurada através de DA.

De acordo com o modelo de virtualidade de Anghern (1997), pode-se dizer que a editora utiliza prioritariamente os espaços de informação e comunicação, e em menor grau os espaços de transação (inserção de pedidos) e de distribuição (download de alguns materiais). A virtualidade afeta razoavelmente a organização (VENKATRAMAN \& HENDERSON, 1998) e o desenvolvimento de novos produtos e serviços (MATTOS \& LAURINDO, 2008).

\subsubsection{Modelos de criação de valor em e-business}

A editora teve contribuição dos direcionadores de eficiência e fidelização propostos por Amit \& Zott (2001). A eficiência foi melhorada com a oferta de conteúdos digitais para as escolas em tempo real e a fidelização foi beneficiada pelo acompanhamento das interações da escola no site. Há espaço para inovação, pois a editora pode lançar novos produtos e serviços baseado nas preferências detectadas no site, mas isso ainda não ocorre.

\subsubsection{Co-criação de valor}

Como dito no tópico anterior, a co-criação de novos produtos e serviços valor é limitada, embora haja potencial para que ela aconteça.

\subsubsection{Estratégia para mercados segmentados}

É possível monitorar as interações por região, essa informação é coletada e armazenada nos sistemas de monitoramento, porém não é utilizada pelos executivos.

\subsubsection{Gestão de negócios}

\subsubsection{Planejamento estratégico}

Os indicadores de DA são considerados pontualmente no planejamento estratégico, há consulta às informações de DA para avaliar a satisfação dos clientes com alguns produtos. 


\subsubsection{Controle de qualidade}

Não há um sistema de qualidade utilizado pela unidade de negócios e as ferramentas da qualidade não são usadas na análise dos indicadores de DA.

\subsubsection{Gestão de conhecimento do consumidor}

Funcionários de diferentes áreas possuem acesso aos indicadores de DA, o consultor pedagógico de determinada região pode saber quais escolas usaram o sistema e que conteúdos foram acessados. O mesmo ocorre com as equipes editorial e comercial. Embora não haja procedimentos para gestão do conhecimento, as informações estão acessíveis a todos os departamentos.

\subsubsection{Análise financeira}

A análise de retorno sobre investimento é feita por projeto. Por exemplo, a editora realizou um investimento considerável para digitalizar a resolução dos exercícios da apostila dos alunos. O retorno sobre esse investimento foi avaliado pelo número de acessos ao material e também pela fidelização dos clientes.

\subsubsection{Síntese do estudo de caso}

Embora haja bastante potencial para que os indicadores de DA impactem nos negócios da editora, a aderência às variáveis de DA é apenas razoável (Tabela 7.6).

\subsection{Estudo de caso F: E-commerce de artigos esportivos}

\subsubsection{Contexto da empresa}

\subsubsection{Informações sobre a indústria}

Entre 2005 e 2010, o e-commerce brasileiro teve um crescimento de $150 \%$ (ECONSULTING, 2011). Nesse período o mercado amadureceu, surgiram novas empresas ampliando o leque de opções ao consumidor. Uma parte significativa dessas empresas atendem a nichos específicos, representando uma tendência de cauda longa (ANDERSON 2006). 
Tabela 7.6: Aderência das práticas da editora às variáveis do framework de DA

\begin{tabular}{|c|c|c|c|}
\hline Constructos & Variáveis & Aderência & Justificativa \\
\hline \multirow{6}{*}{$\begin{array}{l}\text { Capacidade } \\
\text { analítica }\end{array}$} & Inteligência competitiva & Fraca & Limitada a visitas esporádicas a sites de concorrentes \\
\hline & Otimização de presença ativa & Muito fraca & Não há métricas específicas para presença ativa \\
\hline & Mídias sociais & Muito fraca & As mídias sociais não são monitoradas \\
\hline & Usabilidade & Razoável & $\begin{array}{l}\text { Indicadores de uso do site são analisados e afetam a } \\
\text { produção de conteúdo e eventuais mudanças no site }\end{array}$ \\
\hline & Convergência & Razoável & $\begin{array}{l}\text { Número de acessos por escola é indício de que o } \\
\text { relacionamento com cliente está bom }\end{array}$ \\
\hline & Mediana do constructo & Fraca & \\
\hline \multirow[t]{6}{*}{$\begin{array}{l}\text { Contribuição } \\
\text { da Internet } \\
\text { para estratégia }\end{array}$} & Alinhamento entre estratégia e TI & Razoável & $\begin{array}{l}\text { Alinhamento de "Execução da Estratégia", mas pouco } \\
\text { maduro. Mesmo assim DA cumpre algumas funções } \\
\text { estratégicas no relacionamento com consumidor }\end{array}$ \\
\hline & Mudanças no sistema de valor & Razoável & $\begin{array}{l}\text { Parte dos conteúdos é disponibilizada no formato virtual } \\
\text { com uso acompanhado por indicadores de DA }\end{array}$ \\
\hline & $\begin{array}{l}\text { Modelos de criação de valor em } \\
\text { e-business }\end{array}$ & Razoável & $\begin{array}{l}\text { Embora haja espaço para inovação, principais geradores } \\
\text { de valor ainda são a eficiência e a fidelização }\end{array}$ \\
\hline & Co-criação de valor & Fraca & $\begin{array}{l}\text { A editora aproveita pouco o potencial de criar novos } \\
\text { produtos a partir de insights da Internet }\end{array}$ \\
\hline & $\begin{array}{l}\text { Estratégias para mercados } \\
\text { segmentados }\end{array}$ & Fraca & $\begin{array}{l}\text { Há informações de consumidores por região, no entanto, } \\
\text { ela não é utilizada pelos executivos }\end{array}$ \\
\hline & Mediana do constructo & Razoável & \\
\hline \multirow[t]{5}{*}{$\begin{array}{l}\text { Gestão de } \\
\text { negócios }\end{array}$} & Planejamento estratégico & Fraca & $\begin{array}{l}\text { Indicadores de DA são considerados pontualmente no } \\
\text { planejamento estratégico }\end{array}$ \\
\hline & Controle da qualidade & Muito fraca & Não há sistemas de qualidade \\
\hline & $\begin{array}{l}\text { Gestão do conhecimento do } \\
\text { consumidor }\end{array}$ & Razoável & $\begin{array}{l}\text { Diferentes áreas possuem acesso fácil às informações de } \\
\text { DA }\end{array}$ \\
\hline & Análise financeira & Razoável & Retorno medido projeto a projeto \\
\hline & Mediana do constructo & Razoável & \\
\hline \multicolumn{2}{|c|}{ Aplicação de Digital Analytics } & Razoável & $\begin{array}{l}\text { Empresa passa longe do potencial de inovação de DA } \\
\text { para esse tipo de negócio, mesmo assim obteve ganhos } \\
\text { de eficiência }\end{array}$ \\
\hline
\end{tabular}

As forças que moldam a atratividade da indústria são impactantes (PORTER, 1979) com destaque para a rivalidade entre os concorrentes e para o poder de barganha dos fornecedores, que normalmente são grandes marcas e que vendem seus produtos por preços praticamente iguais a todos os players, dificultando uma vantagem competitiva através de preço (Figura 7.9). A logística tem sido um desafio nesse mercado, algumas lojas de e-commerce importantes tem enfrentado problemas na entrega dos produtos vendidos, ensejando ações restritivas do Procon (SAMPAIO, 2012).

\subsubsection{Produtos e serviços da empresa}

A empresa vende artigos esportivos, no início, o foco eram os calçados, pois o negócio teve origem numa rede de sapatarias com lojas físicas no município de 
São Paulo. Atualmente, a loja vende na Internet qualquer peça do vestuário, ou acessório necessário para práticas esportivas.

\subsubsection{Estratégia genérica}

A estratégia genérica é de diferenciação. Alguns diferenciais da loja são: a divulgação de produtos baseados no perfil do consumidor, embora algumas lojas procurem fazer essa customização, nem sempre conseguem implementála com sucesso; alguns produtos podem ser personalizados de acordo com opções do consumidor; o atendimento é rápido, inclusive nas mídias sociais.

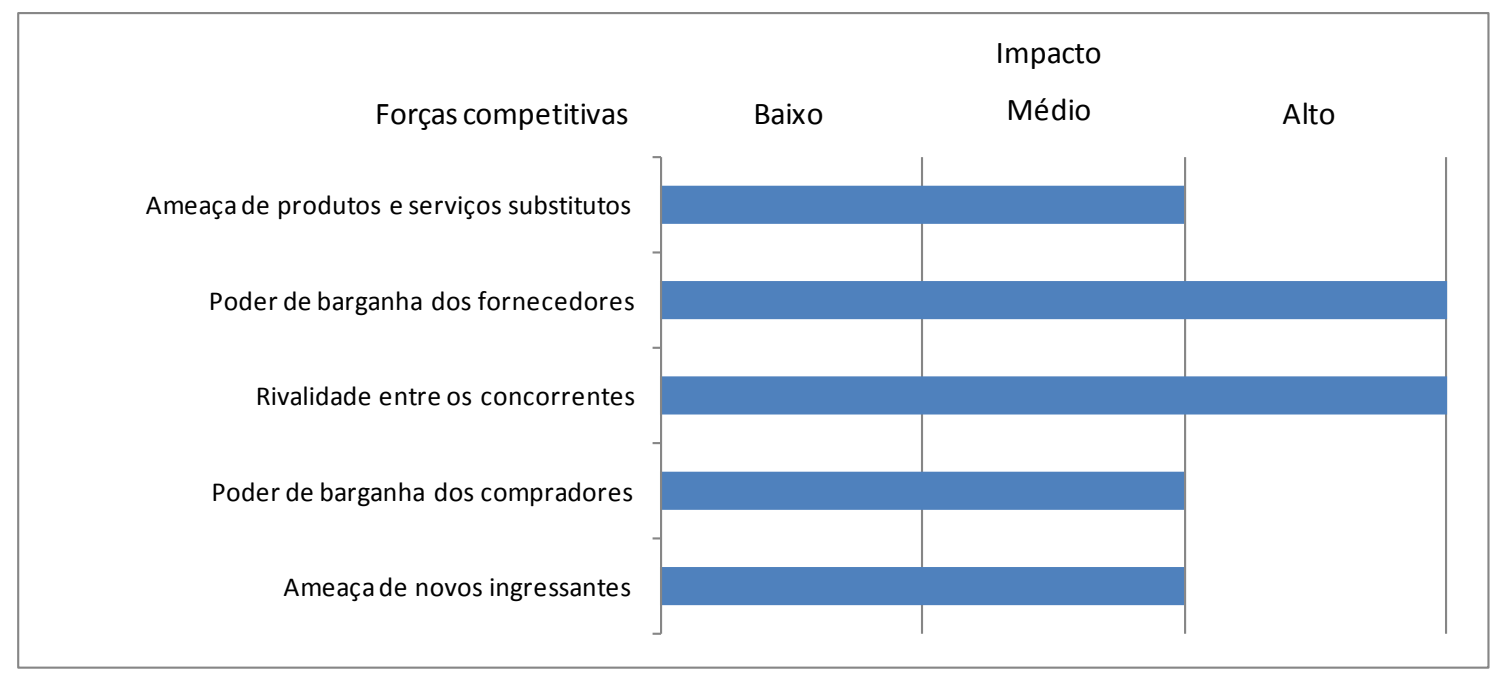

Figura 7.9: Impacto das forças competitivas para o mercado de e-commerce de artigos esportivos (Elaborado pelo autor, baseado em Porter, 1979)

\subsubsection{Organização da tecnologia}

A infra-estrutura de $\mathrm{Tl}$ é parte interna e parte terceirizada. A equipe de $\mathrm{TI}$ é composta de um diretor que gerencia os acordos com empresas terceiras e de alguns desenvolvedores internos. Entre as empresas contratadas há uma agência responsável pelas campanhas e por alguns desenvolvimentos de front end. Os outros fornecedores realizam manutenções nas aplicações de backoffice como o ERP, a ferramenta para personalização do conteúdo e o software de retarget, divulgação de anúncios baseados no perfil do consumidor.

\subsubsection{Presença online}

A empresa possui o seu próprio site de vendas e também oferece a plataforma de e-commerce para diversas lojas na Internet. Por exemplo, algumas lojas de clubes de futebol funcionam na plataforma dessa empresa. 
As campanhas de divulgação da loja e promoções ocorrem durante todo o ano. São campanhas complexas, com diversos produtos e que são segmentadas de acordo com o perfil do cliente.

Além de possuir perfis nas mídias sociais, a loja oferece espaço no próprio site para que os consumidores coloquem comentários sobre os produtos vendidos, facilitando a tomada de decisão do consumidor. Por exemplo, alguns consumidores opinam sobre a numeração dos calçados, alertando se o produto for um pouco maior ou menor do que a numeração declarada na etiqueta.

\subsubsection{Estrutura e organização das atividades de DA}

O site possui Google Analytics implantado e as campanhas são monitoradas através de ferramentas de Ad Server.

Os estudos de DA são considerados tão críticos para o sucesso do negócio que uma equipe da própria empresa analisa os indicadores de DA e elabora sugestões de melhoria que devem ser implantadas rapidamente.

\subsubsection{Competência analítica}

\subsubsection{Inteligência competitiva}

A loja não se limita a fazer benchmarks de empresas nacionais, além do mapeamento dessas empresas, são realizadas visitas a feiras e empresas de outros países para que possam ser absorvidas as melhores práticas do mercado.

Diversas fontes de pesquisa são usadas para o benchmark como: pesquisas de mercado; comentários em mídias sociais e palavras-chave de mecanismos de busca.

Otimização da presença ativa

Para a operação de e-commerce é fundamental acompanhar o ROI de cada campanha. A loja começou sua operação online fazendo investimentos bem modestos em mídia online, porém foi aumentando o investimento conforme o retorno gerado. Além de monitorar o ROI, todas as variáveis do percurso da presença ativa para atração do usuário à loja até a conversão das visitas ao site em vendas são monitoradas. Há parâmetros de desempenho para os indicadores e ações corretivas são os números estão abaixo das metas estipuladas. 


\subsubsection{Mídias sociais}

A loja verifica a opinião dos consumidores nas mídias sociais para avaliar a satisfação com as compras e gerenciar eventuais crises. Respondendo rapidamente caso o consumidor faça uma reclamação que contenha o nome da loja.

O perfil da loja no Facebook conta com um alto número de seguidores e divulga informações sobre esportes, as opiniões dos consumidores também são destacadas na página.

Além do monitoramento em mídias sociais externas para verificar se o consumidor está satisfeito, a loja verifica os comentários sobre produtos feitos no próprio site, mediando algumas reclamações com fornecedores nos casos de problemas de fabricação.

\subsubsection{Usabilidade}

As análises de usabilidade são focadas no funil de conversão do site, pois o aumento da conversão possui relação direta com o ROI das campanhas. São realizados testes e avaliados fatores críticos para conversão como: regras de negócio por tipo de personalização e qualidade das landing pages, essas páginas são o ponto de chegada após o clique numa campanha e sua atratividade pode manter o visitante no site.

\subsubsection{Convergência}

Atualmente, a loja realiza divulgação de seus produtos em TV. Porém não foi identificada uma relação entre os insights de DA e as campanhas offline. As campanhas de TV são institucionais, procurando divulgar a loja e seus benefícios, enquanto as campanhas na Internet tem um forte apelo comercial.

\subsubsection{Contribuições da Internet para estratégia}

\subsubsection{Alinhamento entre estratégia e TI}

A escola de formulação da estratégia é de aprendizado: olhar para o detalhe, na busca das raízes dos fatos (MINTZBERG \& LAMPEL,1999). Isso é revelado pelas adaptações constantes da estratégia baseado no conhecimento trazido pelos indicadores de DA. A estratégia online surgiu através do estudo aprofundado dos fatos gerados pela interação com o consumidor. 
O modelo de alinhamento estratégico é de "Transformação tecnológica" (HENDERSON \& VENKATRAMAN, 1993), uma vez que a loja possuía lojas físicas e migrou para Internet utilizando a estratégia de TI para modificar infraestrutura tecnológica e conseguir atingir mais clientes. O nível de maturidade do alinhamento é de nível 5, pois o planejamento da $\mathrm{TI}$ faz parte do planejamento estratégico do negócio.

Os indicadores de DA são coerentes com esse tipo de alinhamento, pretendese preservar a qualidade da experiência no ambiente virtual e, ao mesmo tempo, realizar inovações para manter uma vantagem competitiva. As atividades de operação e controle dos sistemas de DA são centralizadas (BUCHANAN \& LINOWES, 1980).

\subsubsection{Mudança no sistema de valor}

A integração do sistema de valor é abrangente (PORTER, 2001). O entendimento da demanda é profundo, em alguns casos, os pedidos de grande quantidade são feitos com meses de antecedência. Os fornecedores possuem acesso aos comentários postados no site sobre seus produtos.

O vínculo com os consumidores por sua vez é bastante estreito. A loja consegue se comunicar efetivamente com eles através das mídias sociais e possui indicadores para mensurar a satisfação e observar tendências de consumo.

Segundo o modelo de Anghern (1997) a empresa tirou bastante proveito dos espaços de virtualidade, literalmente migrando sua operação de lojas físicas para lojas virtuais. A virtualidade afetou toda a organização melhorando o conhecimento, a estrutura organizacional ou relacionamento com o consumidor (VENKATRAMAN \& HENDERSON, 1998) ou dando suporte ao processo de criação de novos produtos e serviços (MATTOS \& LAURINDO, 2008).

\subsubsection{Modelos de criação de valor em e-business}

A empresa criou valor através dos 4 direcionadores (AMIT \& ZOTT, 2001):

- Eficiência: Informações que facilitam a tomada de decisão de compra; gestão de campanhas e do funil de conversão do site;

- Complementaridade: Parceria com fornecedores que permitiu personalização de alguns produtos; 
- Fidelização: Ofertas personalizadas por perfil do consumidor e atendimento diferenciado;

- Inovação: Agilidade ao incorporar novidades tecnológicas ainda não assimiladas pelos concorrentes.

\subsubsection{Co-criação de valor}

A empresa monitora e entende os comportamentos dos consumidores e gera novos serviços e ofertas baseados nos segmentos de clientes.

Por exemplo, notou-se que um determinado público possui menor poder aquisitivo, a loja procurou realizar acordos com fornecedores de marcas renomadas, para vender produtos a um valor menor que $R \$ 200,00$. Esses produtos foram oferecidos em mídias específicas associadas a pessoas de baixa renda, como a tela de logout do Orkut, que é acessada por pessoas que usam computadores em locais públicos como lan-houses e precisam sair da aplicação ao fim da visita.

Outra característica de co-criação de valor são as opiniões dos usuários sobre produtos vendidos na loja. Os usuários socializam suas experiências com o produto e tomam decisões de compra baseados nesses aprendizados. Por exemplo, "essa chuteira é para quem gosta de dar direção na bola", "essa aguenta chuva e lama".

\subsubsection{Estratégia para mercados segmentados}

A ferramenta de personalização classificou diversos segmentos de fornecedores que não eram evidentes. Há estratégias definidas com ofertas e regras de negócios próprias para cada segmento. Por exemplo, descobriu-se que as mães compram produtos para elas e para seus filhos, por esse motivo, a loja oferece descontos especiais para pessoas com esse perfil, pois sabe que as compras serão rentabilizadas de acordo com o hábito de consumo dessas mulheres.

\subsubsection{Gestão de negócios}

\subsubsection{Planejamento estratégico}

Os indicadores de DA são intrínsecos às metas de negócios, não apenas pelo negócio ser digital, mas pelo alinhamento da estratégia com a TI ser baseado 
em transformação tecnológica. Isso faz com que os indicadores de DA sejam apreciados como fonte de melhoria contínua.

\subsubsection{Controle de qualidade}

Embora não haja registro de sistemas de controle de qualidade, há uma grande preocupação com a satisfação do consumidor, o que faz com que a empresa procure descobrir a causa raiz de eventuais problemas e implemente soluções rapidamente.

\subsubsection{Gestão de conhecimento do consumidor}

Não há políticas formais para gestão do conhecimento que, em grande parte, é detido pelas pessoas que trabalham na operação, representando um risco para a organização. Pelo fato da loja ser digital, as informações sobre o consumidor são digitalizadas e disponibilizadas a todos os envolvidos, mas a forma como as decisões são tomadas depende das pessoas e não existe formalização dos critérios adotados.

\subsubsection{Análise financeira}

A análise de ROI faz parte do DNA do negócio. Desde a primeira campanha, o ROI é mensurado e são analisados os fatores que podem impactá-lo. Pode-se dizer inclusive que o motivo da empresa ter migrado da loja física para a loja virtual foi o ROI das campanhas na Internet. A primeira campanha da empresa teve um investimento excessivamente baixo para uma campanha na Internet. Porém, o retorno dessa e de sucessivas campanhas foi o motivo da transição para o negócio digital.

O histórico de retorno e a taxa de crescimento da loja são tão consistentes que o banco que atende a empresa criou uma linha de crédito específica, para financiar o crescimento do negócio.

\subsubsection{Síntese do estudo de caso}

De acordo com as variáveis propostas de Capacidade Analítica, Contribuição dalnternet para a Estratégia e Gestão do Negócio, a empresa desse estudo de caso possui forte aderência com as práticas de DA (Tabela 7.7). 
Tabela 7.7: Aderência das práticas da loja de e-commerce às variáveis do framework de DA

\begin{tabular}{|c|c|c|c|}
\hline Constructos & Variáveis & Aderência & Justificativa \\
\hline \multirow[t]{6}{*}{$\begin{array}{l}\text { Capacidade } \\
\text { analítica }\end{array}$} & Inteligência competitiva & Muito forte & $\begin{array}{l}\text { Diversas fontes de pesquisa, benchmark nacional e } \\
\text { internacional }\end{array}$ \\
\hline & Otimização de presença ativa & Muito forte & $\begin{array}{l}\text { Existem indicadores e metas associadas que são } \\
\text { normalmente atingidas devido as análises de otimização }\end{array}$ \\
\hline & Mídias sociais & Muito forte & $\begin{array}{l}\text { Monitoramento de mídias sociais externas e comentários } \\
\text { feitos no próprio site }\end{array}$ \\
\hline & Usabilidade & Muito forte & $\begin{array}{l}\text { Navegação inteiramente otimizada e indicadores } \\
\text { acompanhados sistematicamente }\end{array}$ \\
\hline & Convergência & Muito fraca & $\begin{array}{l}\text { Não foi identificada nenhuma análise que relacionasse } \\
\text { ações on e offline }\end{array}$ \\
\hline & Mediana do constructo & Muito forte & \\
\hline \multirow{6}{*}{$\begin{array}{l}\text { Contribuição } \\
\text { da Internet } \\
\text { para estratégia }\end{array}$} & Alinhamento entre estratégia e $\mathrm{TI}$ & Muito forte & $\begin{array}{l}\text { Estratégia de negócios bastante alinhada com estratégia } \\
\text { de TI através de "Transformação Tecnológica" }\end{array}$ \\
\hline & Mudanças no sistema de valor & Muito forte & $\begin{array}{l}\text { Alta integração com fornecedores e consumidores com } \\
\text { proveito do potencial de virtualidade }\end{array}$ \\
\hline & $\begin{array}{l}\text { Modelos de criação de valor em } \\
\text { e-business }\end{array}$ & Muito forte & Geração de valor através dos 4 direcionadores \\
\hline & Co-criação de valor & Muito forte & $\begin{array}{l}\text { Co-criação através do entendimento profundo sobre o } \\
\text { consumidor }\end{array}$ \\
\hline & $\begin{array}{l}\text { Estratégias para mercados } \\
\text { segmentados }\end{array}$ & Muito forte & $\begin{array}{l}\text { Entendimento leva a campanhas e ofertas específicas por } \\
\text { segmento de público }\end{array}$ \\
\hline & Mediana do constructo & Muito forte & \\
\hline \multirow[t]{5}{*}{$\begin{array}{l}\text { Gestão de } \\
\text { negócios }\end{array}$} & Planejamento estratégico & Muito forte & $\begin{array}{l}\text { Indicadores de DA fortemente relacionados com a } \\
\text { estratégia }\end{array}$ \\
\hline & Controle da qualidade & Forte & $\begin{array}{l}\text { Embora não haja sistema da qualidade, há controle de } \\
\text { qualidade baseado na satisfação do consumidor }\end{array}$ \\
\hline & $\begin{array}{l}\text { Gestão do conhecimento do } \\
\text { consumidor }\end{array}$ & Forte & $\begin{array}{l}\text { Não há processos formais, mas as informações de DA são } \\
\text { disseminadas entre as áreas de negócios e de TI }\end{array}$ \\
\hline & Análise financeira & Forte & $\begin{array}{l}\text { Análise precisa do ROI com forte otimização das } \\
\text { campanhas }\end{array}$ \\
\hline & Mediana do constructo & Muito forte & \\
\hline \multicolumn{2}{|c|}{ Aplicação de Digital Analytics } & Muito forte & $\begin{array}{l}\text { A empresa aplica DA com sucesso em suas estratégias de } \\
\text { negócios }\end{array}$ \\
\hline
\end{tabular}




\subsection{Estudo de caso G: Grupo Musical "A Banda Mais Bonita da Cidade"}

\subsubsection{Contexto da empresa}

\subsubsection{Informações sobre a indústria}

O grupo "A Banca Mais Bonita da Cidade" foi a única entidade analisada que concordou em publicar seu nome no estudo de caso. A indústria da qual a banda faz parte é a fonográfica, que tem sentido o impacto de produtos substitutos como os arquivos de músicas MP3; a concorrência desleal da pirataria, que não paga impostos ou direitos autorais; a segmentação das preferências do consumidor, que antes era limitada a alguns artistas e hoje se estende a uma infinidade de bandas e cantores que representam segmentos específicos (BRYNJOLFSSON, 2003; ANDERSON, 2006); e a entrada de novos ingressantes devido à facilidade de acesso aos meios de produção proporcionada pela tecnologia. Devido a essas variáveis, a atratividade dessa indústria é bastante limitada (PORTER, 1979).

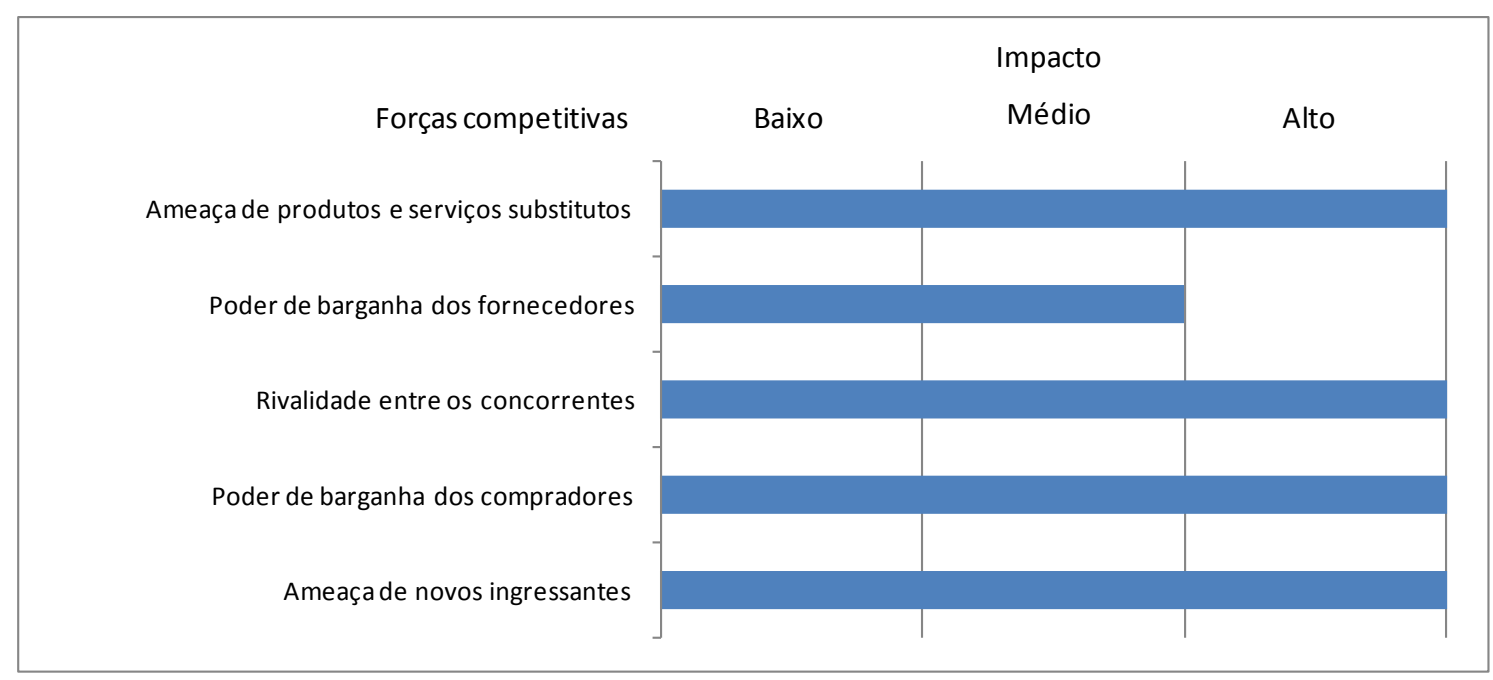

Figura 7.10: Impacto das forças competitivas para o mercado de e-commerce de artigos esportivos (Elaborado pelo autor, baseado em Porter, 1979)

\subsubsection{Produtos e serviços da empresa}

O serviço da empresa são os shows realizados em todo o Brasil. As músicas do grupo são distribuídas gratuitamente na Internet e também há um Álbum que pode ser adquirido na Internet. Os integrantes da banda consideram que não faz sentido restringir a acesso às músicas digitalizadas, pois de qualquer 
forma, o público vai copiar essas músicas, sendo assim eles próprios oferecem a música no site da Banda.

\subsubsection{Estratégia genérica}

A estratégia genérica é de enfoque. O som da Banda é bastante autoral, sem concessões ao mercado, e de difícil classificação. Ela possui um grupo de fãs bastante engajados que chegaram inclusive a patrocinar a gravação do primeiro álbum.

\subsubsection{Organização da tecnologia}

Não há uma estrutura de TI. O desenvolvimento do site foi terceirizado e o perfil no Facebook e os vídeos compartilhados no Youtube são de produção caseira.

\subsubsection{Presença online}

A Banda possui um site onde vende seu álbum e também oferece as músicas digitalizadas para download. A venda do álbum e de outros artigos da banda é feita através da Likestore do Facebook.

O perfil no Facebook da Banda possui mais de 120 mil seguidores. Nesse perfil, a Banda anuncia shows, troca ideias com seus fãs sobre o Álbum, a elaboração de videoclipes e as cidades para os próximos shows.

O Youtube é utilizado para divulgação dos videoclipes, sendo que o mais divulgado é o videoclipe "Oração" com mais de 10 milhões de visualizações.

\subsubsection{Estrutura e organização das atividades de DA}

A Banda não possui uma estrutura de DA, nem realiza análises formais. As informações de gostos e preferências dos consumidores são utilizadas naturalmente pela Banda nos momentos de criação e na tomada de decisão sobre turnês e seleção de faixas para o álbum.

\subsubsection{Competência analítica}

\subsubsection{Inteligência competitiva}

A banda não possui painéis de controle da concorrência, pois não há um concorrente claro, nem a intenção de se pautar por fatores de mercado. 
Há monitoramento não estruturado das redes sociais que permite a geração de insights para produtos e serviços.

Otimização da presença ativa

A Banda não realiza ações de campanha em portais ou em links patrocinados. A sua divulgação é feita através dos próprios fãs através da viralização dos vídeoclipes nas mídias sociais. Os fãs divulgam o link com o vídeo em seus próprios perfis, em alguns casos, criam paródias dos videoclipes, fazendo que o usuário que não conheço o vídeo original o veja por curiosidade (figura 7.11). Os indicadores monitorados são o número de views e os usuários mais influentes.

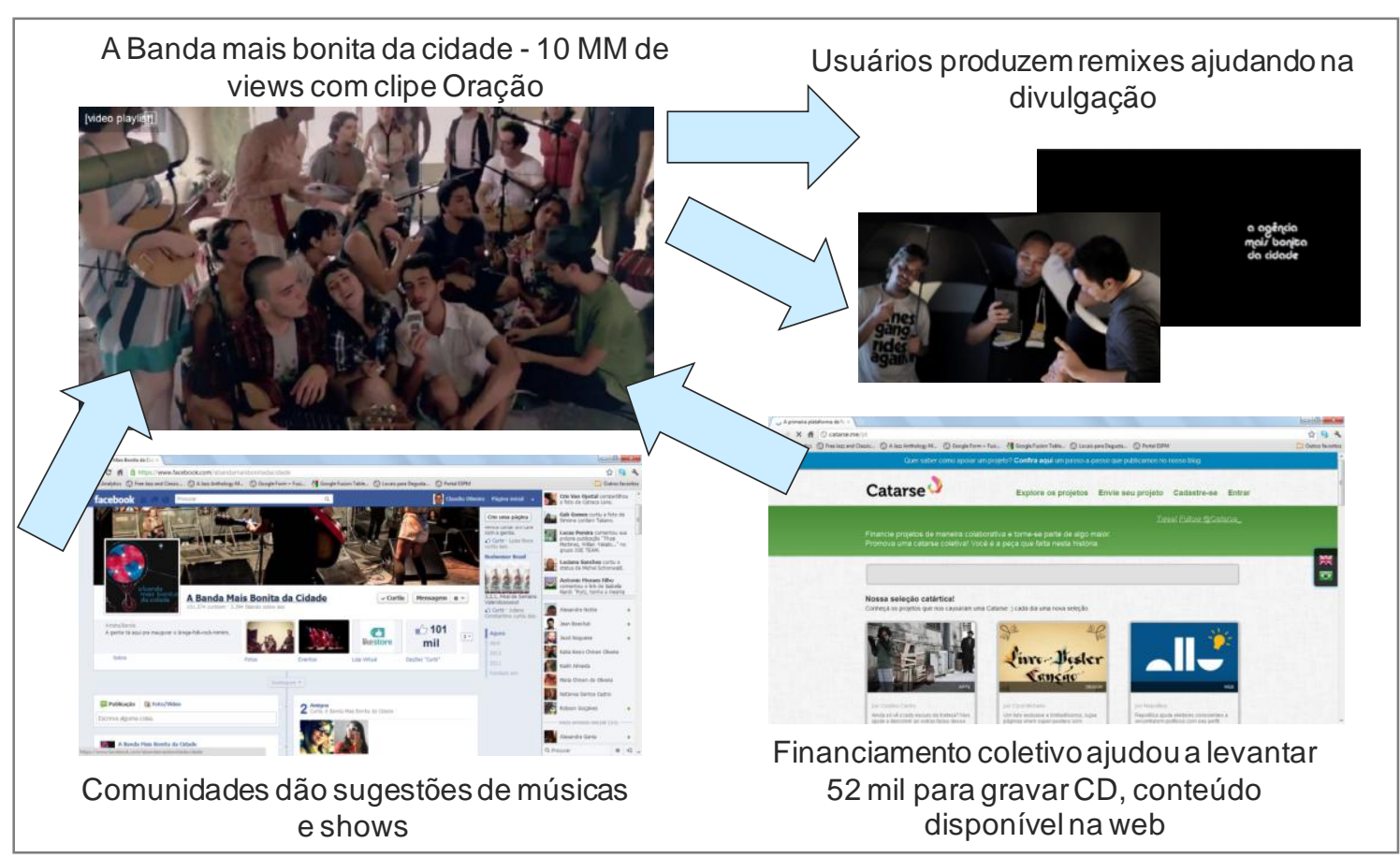

Figura 7.11: Processo de comunicação e financiamento da Banda Mais Bonita da Cidade

\subsubsection{Mídias sociais}

As mídias sociais representam um papel importante nas decisões tomadas pelo grupo. Os comentários são lidos pelos próprios integrantes que procuram responder diretamente aos seus fãs. Preferências sobre locais de shows e sugestões das músicas a serem gravadas são coletadas nas mídias sociais.

O financiamento da banda é feito através de financiamento coletivo (crowdfunding), os fãs financiaram as músicas que gostariam que fossem gravadas no site Catarse.me. Um indicador de sucesso nas mídias sociais são as músicas que obtiveram financiamento. 


\subsubsection{Usabilidade}

Não há acompanhamento sistemático de indicadores de usabilidade. São feitos ajustes no site e na fan page no Facebook caso haja solicitação.

\subsubsection{Convergência}

Talvez esse caso represente o exemplo de maior convergência entre os processos online e offline, ficando difícil separar o que é virtual das atividades físicas. Através de uma gravadora tradicional, dificilmente uma banda desse tipo teria sucesso. Porém a Banda utilizou a Internet como meio de divulgação e seus próprios fãs divulgaram as músicas. Os shows e vendas no marketplace são uma consequência do sucesso no marketspace (RAYPORT \& SVIOKLA, 1995).

\subsubsection{Contribuições da Internet para estratégia}

\subsubsection{Alinhamento entre estratégia e TI}

A formulação da estratégia ocorre através do Design, busca-se uma perspectiva estratégica visualizando um futuro próximo como o lançamento de um novo álbum (MINTZBERG \& LAMPEL,1999).

O modelo de alinhamento estratégico é de "Transformação tecnológica" (HENDERSON \& VENKATRAMAN, 1993). A estratégia de negócios é aderente à estratégia de TI, a tecnologia é usada para vencer as limitações de organização e distribuição de um sistema de valor tradicional em que a Banda precisaria de uma gravadora para apoiar a divulgação das músicas em veículos de massa como rádio e TV e distribuição do álbum em lojas físicas (Figura 7.12). O nível de maturidade desse alinhamento é de processos otimizados, nível 5, pois o planejamento online é intrínseco ao planejamento de negócios (LUFTMAN, 2003).

O controle e a execução dos sistemas de DA são centralizados (BUCHANAN \& LINOWES, 1980).

\subsubsection{Sistema de valor}

A integração do sistema de valor é completa (PORTER, 2001). A Banda prescindiu de um sistema de valor tradicional (figura 7.12) em que seria dependente da gravadora para utilizar uma rede de valor onde os diversos 
agentes contribuem para seu sucesso e o formato é flexível (figura 7.13). 0 consumidor pode conhecer as músicas na Internet e baixar as músicas no site ou comprar o Álbum na Likestore do Facebook. O sucesso não depende de gravadoras ou veículos, pois a ligação com o consumidor é direta. Os fornecedores são adicionados no processo de acordo com a necessidade, o estúdio de gravação é usado apenas para gravação das faixas.

A virtualidade afeta toda a organização (VENKATRAMAN \& HENDERSON, 1998) e prove suporte ao processo de criação de novos produtos e serviços (MATTOS \& LAURINDO, 2008).

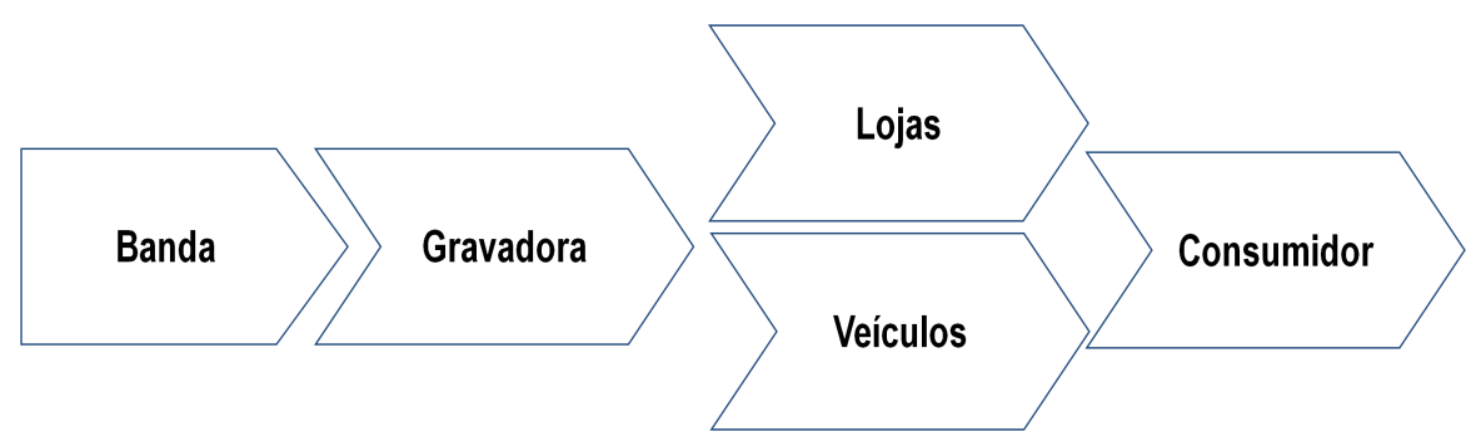

Figura 7.12: Sistema de valor tradicional para indústria fonográfica

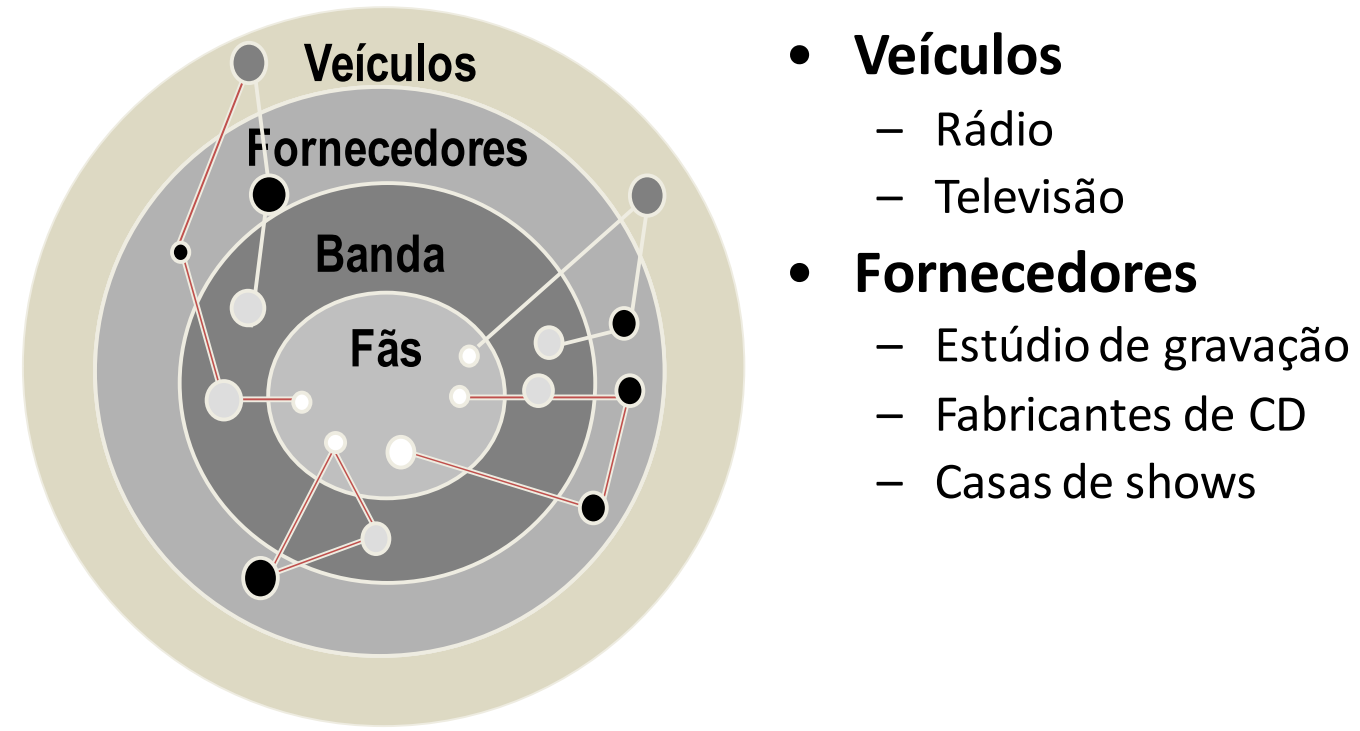

Figura 7.13: Rede de Valor da Banda Mais Bonita da Cidade

\subsubsection{Modelos de criação de valor em e-business}

A empresa criou valor através dos 4 direcionadores propostos por Amit \& Zott (2001): 
- Eficiência: by-pass no sistema de valor tradicional melhorou a eficiência na obtenção dos recursos e na comunicação com os fãs;

- Complementaridade: parcerias da Banda com a loja LikeStore do Facebook e com o site Catarse.me foram importantes para gerar recursos;

- Fidelização: contato direto com fãs melhora o relacionamento e aumenta a fidelização;

- Inovação: modelo de negócios baseado fortemente na virtualidade.

\subsubsection{Co-criação de valor}

O modelo de criação de valor é tão socializado que se pode dizer que uma música é gravada ou um show é realizado apenas se houver aceitação do público. Entre os estudos de caso, esse é o modelo mais radical de co-criação que está presente em todo o processo da banda.

\subsubsection{Estratégia para mercados segmentados}

O projeto da banca atende a um mercado bastante segmentado de música alternativa. A estratégia competitiva é adequada a esse mercado de nicho, o contato próximo de seus fãs seria difícil para um público de massa.

\subsubsection{Gestão de negócios}

\subsubsection{Planejamento estratégico}

Não há um planejamento mercadológico e sim um projeto artístico que procura se manter com o apoio dos fãs. Pode-se dizer que há uma estratégia emergente que surge a partir da interação com os fãs.

\subsubsection{Controle de qualidade}

Não existe um sistema de controle da qualidade, mas há uma preocupação com a satisfação dos fãs manifesta nas respostas aos comentários nas mídias sociais.

\subsubsection{Gestão de conhecimento do consumidor}

O conhecimento do consumidor faz parte do processo criativo através dos feedbacks recebidos nas mídias sociais. O grupo realiza votações e pede 
financiamento para projetos específicos que são levados adiante apenas se houver aceitação dos fãs.

\subsubsection{Análise financeira}

Segundo os membros da Banda, o negócio é viável e a renda de shows, venda de acessórios na Likestore é suficiente para cobrir os custos. Não há cálculos de ROI sobre os investimentos de marketing, pois a divulgação da banda é orgânica e realizada através da viralização dos conteúdos da Banda nas mídias sociais.

7.7.5 Síntese do estudo de caso

De acordo com as variáveis propostas de Capacidade Analítica, Contribuição dalnternet para a Estratégia e Gestão do Negócio, a empresa desse estudo de caso possui forte aderência com as práticas de DA (Tabela 7.8). 
Tabela 7.8: Aderência das práticas do grupo musical às variáveis do framework de DA

\begin{tabular}{|c|c|c|c|}
\hline Constructos & Variáveis & Aderência & Justificativa \\
\hline \multirow[t]{6}{*}{$\begin{array}{l}\text { Capacidade } \\
\text { analítica }\end{array}$} & Inteligência competitiva & Razoável & $\begin{array}{l}\text { Monitoramento de redes sociais para entendimento do } \\
\text { mercado }\end{array}$ \\
\hline & Otimização de presença ativa & Forte & Acompanhamento da viralização de vídeos na Internet \\
\hline & Mídias sociais & Muito forte & $\begin{array}{l}\text { Forte acompanhamento da publicação dos fãs nas mídias } \\
\text { sociais }\end{array}$ \\
\hline & Usabilidade & Razoável & Ajustes feitos sob demanda do usuário \\
\hline & Convergência & Muito forte & $\begin{array}{l}\text { Indicadores de DA impactam nos álbuns lançados e no } \\
\text { roteiro de shows }\end{array}$ \\
\hline & Mediana do constructo & Forte & \\
\hline \multirow{6}{*}{$\begin{array}{l}\text { Contribuição } \\
\text { da Internet } \\
\text { para estratégia }\end{array}$} & Alinhamento entre estratégia e TI & Muito forte & DA suportou estratégia de virtualização da Banda \\
\hline & Mudanças no sistema de valor & Muito forte & $\begin{array}{l}\text { Banda aproveitou oportunidade de mudança no sistema } \\
\text { de valor da indústria fonográfica, para criar modelo de } \\
\text { negócios virtual }\end{array}$ \\
\hline & $\begin{array}{l}\text { Modelos de criação de valor em } \\
\text { e-business }\end{array}$ & Muito forte & $\begin{array}{l}\text { A Banda gerou valor através dos } 4 \text { direcionadores de } \\
\text { criação de valor em e-business }\end{array}$ \\
\hline & Co-criação de valor & Muito forte & Fãs influenciam produção fonográfica e financiam o grupo \\
\hline & $\begin{array}{l}\text { Estratégias para mercados } \\
\text { segmentados }\end{array}$ & Razoável & $\begin{array}{l}\text { Banda atende um nicho de mercado específico com } \\
\text { estratégia de enfoque usando alguns elementos de DA }\end{array}$ \\
\hline & Mediana do constructo & Muito forte & \\
\hline \multirow[t]{5}{*}{$\begin{array}{l}\text { Gestão de } \\
\text { negócios }\end{array}$} & Planejamento estratégico & Muito Forte & $\begin{array}{l}\text { Estratégia emergente que surge a partir da interação com } \\
\text { os fãs }\end{array}$ \\
\hline & Controle da qualidade & Fraca & $\begin{array}{l}\text { Não existe um sistema de controle da qualidade, mas há } \\
\text { uma preocupação com a satisfação dos fãs }\end{array}$ \\
\hline & $\begin{array}{l}\text { Gestão do conhecimento do } \\
\text { consumidor }\end{array}$ & Muito forte & $\begin{array}{l}\text { Conhecimento do consumidor faz parte do processo } \\
\text { criativo através dos feedbacks através das mídias sociais }\end{array}$ \\
\hline & Análise financeira & Razoável & $\begin{array}{l}\text { Negócio é rentável, embora não haja cálculos sofisticados } \\
\text { de ROI }\end{array}$ \\
\hline & Mediana do constructo & Muito forte & \\
\hline \multicolumn{2}{|c|}{ Aplicação de Digital Analytics } & Muito forte & $\begin{array}{l}\text { Negócio é rentável, embora não haja cálculos sofisticados } \\
\text { de ROI }\end{array}$ \\
\hline
\end{tabular}




\section{Discussão dos resultados da pesquisa}

\subsection{Objetivos da pesquisa}

Essa pesquisa teve como objetivo principal entender como as empresas utilizam o conceito de DA e elencar fatores críticos para que elas possam obter máximo proveito de uma implantação de DA. A partir desse objetivo, foram detalhados quatro objetivos específicos que serão revisitados nessa discussão dos resultados:

i. Montar um framework de DA a partir dos constructos identificados na literatura

ii. Verificar empiricamente a aplicação desse framework nas empresas brasileiras

iii. Avaliar o alinhamento estratégico de DA e sua eficácia para os negócios

iv. Identificar os principais elementos de sucesso na implantação de DA

\subsection{Framework de DA}

A partir de uma extensa pesquisa bibliográfica foram identificados 3 constructos: Capacidade analítica; Contribuições da Internet para Estratégia e Gestão de negócios. Esses constructos foram desdobrados em variáveis e premissas compondo o framework de DA conforme a tabela 8.1. 
Tabela 8.1: Framework de DA

\begin{tabular}{|c|c|c|}
\hline Constructos & Variáveis & Premissas \\
\hline \multirow{5}{*}{$\begin{array}{l}\text { Capacidade } \\
\text { analítica }\end{array}$} & $\begin{array}{l}\text { Inteligência } \\
\text { competitiva }\end{array}$ & $\begin{array}{l}\text { A inteligência competitiva é incrementada com informações sobre a audiência } \\
\text { e as funcionalidades dos sites concorrentes (TARAPANOFF, 2004; WAA, } \\
\text { 2008; YANAZE, 2011) }\end{array}$ \\
\hline & $\begin{array}{l}\text { Otimização de } \\
\text { presença ativa }\end{array}$ & $\begin{array}{l}\text { As campanhas online são otimizadas através do acompanhamento de seus } \\
\text { indicadores de eficiência e eficácia (FOX, 2010; SCOTT, 2011; ENGE et al., } \\
\text { 2009; MAYAR \& RAMSEY, 2011; FARRIS et al., 2007) }\end{array}$ \\
\hline & Mídias sociais & $\begin{array}{l}\text { A influência das marcas, os sentimentos do consumidor e a intenção de } \\
\text { compra podem ser mensurados nas mídias sociais (STERN, 2010; CUI e } \\
\text { GUO, 2009; LIMA et al., 2005; KLOUT, 2012; SPONDER, 2012; KAUSHIK, } \\
\text { 2010) }\end{array}$ \\
\hline & Usabilidade & $\begin{array}{l}\text { Analisando a usabilidade de seu site, as empresas propõem a melhoria } \\
\text { contínua da conversão de visitas em ações (KAUSHIK, 2009; CUTRONI, } \\
\text { 2010) }\end{array}$ \\
\hline & Convergência & $\begin{array}{l}\text { A integração entre as informações dos diversos canais de contato com o } \\
\text { consumidor, sejam online ou offline, são relevantes para os negócios } \\
\text { (BUGHIN et al, 2008; SHANKAR \& YADAV, 2010) }\end{array}$ \\
\hline \multirow{5}{*}{$\begin{array}{l}\text { Contribuições da } \\
\text { DA para } \\
\text { Estratégia }\end{array}$} & $\begin{array}{l}\text { Alinhamento entre } \\
\text { estratégia e TI }\end{array}$ & $\begin{array}{l}\text { O alinhamento entre TI e estratégia é relevante para a eficácia dos } \\
\text { investimentos em TI, sendo relevante também para as implantações de DA } \\
\text { (ROCKART, 1979; PORTER \& MILLAR, 1985, PORTER, 2001; } \\
\text { HENDERSON \& VENKATRAMAN, 1993; LAURINDO, 2008). Esse } \\
\text { alinhamento pode ser classificado pela maneira como a estratégia de } \\
\text { negócios é formulada (MINTZBERG \& LAMPEL, 1999), o grau de maturidade } \\
\text { desse alinhamento (LUFTMAN, 2003) e a descentralização da operação e o } \\
\text { controle da TI/DA (BUCHANAN \& LINOWES,1980) }\end{array}$ \\
\hline & $\begin{array}{l}\text { Mudanças no } \\
\text { sistema de valor }\end{array}$ & $\begin{array}{l}\text { A Internet transforma o sistema de valor através de maior integração } \\
\text { (PORTER, 2001); as implicações da virtualidade nos negócios (ANGHERN, } \\
\text { 1997); a adição de elementos das cadeias de valor virtuais } \\
\text { (CHANDRASHEKAR \& SCHARY, 1999; RAYPORT \& SVIOKLA, 1995) e/ou } \\
\text { formação de redes de valor entre os agentes desse sistema (BOVET \& } \\
\text { MARTHA, 2001). A virtualidade pode ocorrer toda a organização } \\
\text { (VENKATRAMAN \& HENDERSON, 1998) ou, especificamente, no } \\
\text { desenvolvimento de seus produtos e serviços (MATTOS \& LAURINDO, 2008) }\end{array}$ \\
\hline & $\begin{array}{l}\text { Modelos de criação } \\
\text { de valor em } e^{-} \\
\text {business }\end{array}$ & $\begin{array}{l}\text { Os modelos de negócios específicos para o e-business promovem eficiência, } \\
\text { inovação, fidelização e complementaridades (AMIT \& ZOTT, 2001) }\end{array}$ \\
\hline & Co-criação de valor & $\begin{array}{l}\text { A internet possibilita a co-criação de valor entre a empresa e seus } \\
\text { clientes/consumidores (PRAHALAD \& RAMASWAMY, 2000, 2004; } \\
\text { PRAHALAD \& KRISHNA, 2008; SHAMMA, 2007; TAPSCOTT \& WILLIAMS, } \\
\text { 2007). }\end{array}$ \\
\hline & $\begin{array}{l}\text { Estratégias para } \\
\text { mercados } \\
\text { segmentados }\end{array}$ & $\begin{array}{l}\text { A Internet possibilitou a criação de mercados cada vez mais segmentados } \\
\text { (BRYNJOLFSSON, 2003; ANDERSON, 2006), onde a competição é baseada } \\
\text { em estratégias específicas (KIM \& MAUBORGNE, 2005) }\end{array}$ \\
\hline \multirow{4}{*}{$\begin{array}{l}\text { Gestão de } \\
\text { negócios }\end{array}$} & $\begin{array}{l}\text { Planejamento } \\
\text { estratégico }\end{array}$ & $\begin{array}{l}\text { O alinhamento dos indicadores de DA com o planejamento estratégico da } \\
\text { empresa é crítico para a eficácia nos negócios (ROCKART, 1979; KAPLAN \& } \\
\text { NORTON, 1997; YANAZE, 2011). }\end{array}$ \\
\hline & $\begin{array}{l}\text { Controle da } \\
\text { qualidade }\end{array}$ & $\begin{array}{l}\text { A aplicação das ferramentas da qualidade em DA pode melhorar a } \\
\text { consistência das análises e contribui para melhoria contínua da presença } \\
\text { online. DA também pode contribuir na coleta da voz do cliente para o QFD } \\
\text { (DAVIS et al.,2001). }\end{array}$ \\
\hline & $\begin{array}{l}\text { Gestão do } \\
\text { conhecimento do } \\
\text { consumidor }\end{array}$ & $\begin{array}{l}\text { A gestão do conhecimento do consumidor gerado por DA permite que a } \\
\text { empresa promova a inovação e a melhoria de seus processos (GIBBERT et } \\
\text { al., 2002; ZANINI \& MIGUELES, 2010; FOX, 2010). }\end{array}$ \\
\hline & Análise financeira & $\begin{array}{l}\text { DA pode contribuir para mensuração dos retornos de investimentos em } \\
\text { comunicação online (YANAZE et al., 2010; LENSKOLD, 2003; POWELL, } \\
\text { 2002) }\end{array}$ \\
\hline
\end{tabular}




\subsection{Aplicação do framework de DA nas empresas brasileiras}

A survey exploratória revelou que as práticas de DA são amplamente utilizadas pelas empresas brasileiras:

- $68 \%$ das empresas utilizam a internet para captar informações dos concorrentes;

- $52 \%$ utilizam a web para captar informações de prospects na Internet;

- $48 \%$ das empresas analisam dados de navegação do cliente na web.

Considerando apenas o grupo de empresas incluídas entre as 500 maiores de EXAME, 74\% usam práticas de DA entre essas empresas (WA, 2010).

Os estudos de caso mostraram a aderência das variáveis à realidade encontrada nas empresas, que foi medida numa escala Likert indo do grau de aderência muito fraca até muito forte, conforme pode ser notado na tabela 8.2.

No geral, houve forte aderência das variáveis analisadas através dos estudos de caso e framework de DA. Nota-se que houve bastante variação no grau de aderência de cada variável: a variável "Estratégia para mercados segmentados" teve aderência fraca, enquanto as variáveis "Alinhamento entre estratégia e Tl" e "Modelos de criação de valor em e-business" tiveram aderência muito forte às práticas das empresas analisadas.

O constructo "Capacidade Analítica" teve uma mediana que representou aderência razoável à realidade das empresas analisadas. Com destaque para as variáveis "Otimização da Presença Ativa" e "Análise de Mídias Sociais", em que a prática das empresas mostrou-se mais alinhada às premissas do framework de DA. Isso demonstra maiores esforços de DA nessas variáveis específicas, com menor prioridade para análises de "Inteligência Competitiva", "Usabilidade" e "Convergência de informações on e offline".

O constructo "Contribuição da Internet para a Estratégia" teve aderência forte às práticas das empresas. Foi notado o alto grau de "Alinhamento entre Estratégia e TI" em 4 casos. Nesses 4 casos, a aderência a todo o framework de DA foi de forte para muito forte. Sugerindo que essa variável possui alta influência nas implantações de DA como será discutido no próximo tópico. As variáveis "Mudança no Sistema de Valor" e "Modelos de Criação de Valor" em e-business tiveram forte aderência, mostrando que a forma de criar valor está 
sendo bastante impactada pela virtualidade nas empresas analisadas. A "CoCriação de Valor" é apenas razoável nas empresas estudadas e as "Estratégias para Mercados Segmentados" ainda são incipientes, demonstrando ainda falta de arrojo na utilização de variáveis que seriam importantes para geração de vantagem competitiva.

Tabela 8.2: Aderência das variáveis de DA aos estudos de caso

\begin{tabular}{|c|c|c|c|c|c|c|c|c|c|}
\hline Constructos & Variáveis & 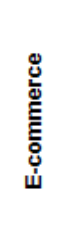 & 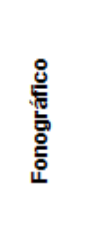 & 悹 & 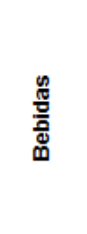 & 똥 & $\begin{array}{l}\text { 은 } \\
\text { 恚 } \\
\text { ’ }\end{array}$ & $\begin{array}{l}\text { 뚠 } \\
\text { 률 } \\
\text { 흘 }\end{array}$ & 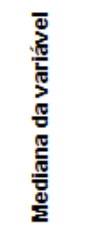 \\
\hline \multirow{6}{*}{$\begin{array}{l}\text { Capacidade } \\
\text { analítica }\end{array}$} & Inteligência competitiva & $\begin{array}{l}\text { Muito } \\
\text { Forte }\end{array}$ & $\begin{array}{c}\text { Razoá- } \\
\text { vel }\end{array}$ & $\begin{array}{l}\text { Muito } \\
\text { Forte }\end{array}$ & $\begin{array}{l}\text { Muito } \\
\text { Forte }\end{array}$ & Fraca & Fraca & $\begin{array}{c}\text { Razoá- } \\
\text { vel }\end{array}$ & $\begin{array}{c}\text { Razoá- } \\
\text { vel }\end{array}$ \\
\hline & Otimização de presença ativa & $\begin{array}{l}\text { Muito } \\
\text { Forte }\end{array}$ & Forte & Forte & $\begin{array}{l}\text { Muito } \\
\text { Forte }\end{array}$ & $\begin{array}{l}\text { Muito } \\
\text { Fraca }\end{array}$ & Fraca & Fraca & Forte \\
\hline & Mídias sociais & $\begin{array}{l}\text { Muito } \\
\text { Forte }\end{array}$ & $\begin{array}{l}\text { Muito } \\
\text { Forte }\end{array}$ & $\begin{array}{l}\text { Muito } \\
\text { Fraca }\end{array}$ & Forte & $\begin{array}{l}\text { Muito } \\
\text { Fraca }\end{array}$ & Forte & Fraca & Forte \\
\hline & Usabilidade & $\begin{array}{l}\text { Muito } \\
\text { Forte }\end{array}$ & $\begin{array}{c}\text { Razoá- } \\
\text { vel }\end{array}$ & $\begin{array}{c}\text { Razoá- } \\
\text { vel }\end{array}$ & $\begin{array}{c}\text { Razoá- } \\
\text { vel }\end{array}$ & $\begin{array}{c}\text { Razoá- } \\
\text { vel }\end{array}$ & Forte & Fraca & $\begin{array}{c}\text { Razoá- } \\
\text { vel }\end{array}$ \\
\hline & Convergência & $\begin{array}{l}\text { Muito } \\
\text { fraca }\end{array}$ & $\begin{array}{l}\text { Muito } \\
\text { Forte }\end{array}$ & $\begin{array}{l}\text { Muito } \\
\text { Forte }\end{array}$ & Fraca & $\begin{array}{c}\text { Razoá- } \\
\text { vel }\end{array}$ & $\begin{array}{l}\text { Muito } \\
\text { Fraca }\end{array}$ & Fraca & $\begin{array}{c}\text { Razoá- } \\
\text { vel }\end{array}$ \\
\hline & Mediana do constructo & $\begin{array}{l}\text { Muito } \\
\text { Forte }\end{array}$ & Forte & Forte & Forte & Fraca & Fraca & Fraca & $\begin{array}{c}\text { Razoá- } \\
\text { vel }\end{array}$ \\
\hline \multirow{6}{*}{$\begin{array}{l}\text { Contribuição da } \\
\text { Internet para } \\
\text { estratégia }\end{array}$} & Alinhamento entre estratégia e TI & $\begin{array}{l}\text { Muito } \\
\text { Forte }\end{array}$ & $\begin{array}{l}\text { Muito } \\
\text { Forte }\end{array}$ & $\begin{array}{l}\text { Muito } \\
\text { Forte }\end{array}$ & $\begin{array}{l}\text { Muito } \\
\text { Forte }\end{array}$ & $\begin{array}{c}\text { Razoá- } \\
\text { vel }\end{array}$ & Fraca & Fraca & $\begin{array}{l}\text { Muito } \\
\text { Forte }\end{array}$ \\
\hline & Mudanças no sistema de valor & $\begin{array}{l}\text { Muito } \\
\text { Forte }\end{array}$ & $\begin{array}{l}\text { Muito } \\
\text { Forte }\end{array}$ & Forte & Forte & $\begin{array}{c}\text { Razoá- } \\
\text { vel }\end{array}$ & $\begin{array}{l}\text { Razoá- } \\
\text { vel }\end{array}$ & $\begin{array}{l}\text { Razoá- } \\
\text { vel }\end{array}$ & Forte \\
\hline & Modelos de criação de valor em e-business & $\begin{array}{l}\text { Muito } \\
\text { Forte }\end{array}$ & $\begin{array}{l}\text { Muito } \\
\text { Forte }\end{array}$ & $\begin{array}{l}\text { Muito } \\
\text { Forte }\end{array}$ & $\begin{array}{l}\text { Muito } \\
\text { Forte }\end{array}$ & $\begin{array}{c}\text { Razoá- } \\
\text { vel }\end{array}$ & Fraca & Fraca & $\begin{array}{l}\text { Muito } \\
\text { Forte }\end{array}$ \\
\hline & Co-criação de valor & $\begin{array}{l}\text { Muito } \\
\text { Forte }\end{array}$ & $\begin{array}{l}\text { Muito } \\
\text { Forte }\end{array}$ & $\begin{array}{l}\text { Razoá- } \\
\text { vel }\end{array}$ & Fraca & Fraca & $\begin{array}{l}\text { Razoá- } \\
\text { vel }\end{array}$ & $\begin{array}{l}\text { Muito } \\
\text { Fraca }\end{array}$ & $\begin{array}{l}\text { Razoá- } \\
\text { vel }\end{array}$ \\
\hline & Estratégias para mercados segmentados & $\begin{array}{l}\text { Muito } \\
\text { Forte }\end{array}$ & $\begin{array}{l}\text { Razoá- } \\
\text { vel }\end{array}$ & Forte & $\begin{array}{l}\text { Muito } \\
\text { Fraca }\end{array}$ & Fraca & Fraca & $\begin{array}{l}\text { Muito } \\
\text { Fraca }\end{array}$ & Fraca \\
\hline & Médianado constructo & $\begin{array}{l}\text { Muito } \\
\text { Forte }\end{array}$ & $\begin{array}{l}\text { Muito } \\
\text { Forte }\end{array}$ & Forte & Forte & $\begin{array}{l}\text { Razoá- } \\
\text { vel }\end{array}$ & Fraca & Fraca & Forte \\
\hline \multirow{5}{*}{$\begin{array}{l}\text { Gestão de } \\
\text { negócios }\end{array}$} & Planejamento estratégico & $\begin{array}{l}\text { Muito } \\
\text { Forte }\end{array}$ & $\begin{array}{l}\text { Muito } \\
\text { forte }\end{array}$ & Forte & Forte & Fraca & $\begin{array}{l}\text { Razoá- } \\
\text { vel }\end{array}$ & Fraca & Forte \\
\hline & Controle da qualidade & $\begin{array}{l}\text { Muito } \\
\text { Forte }\end{array}$ & Fraca & $\begin{array}{l}\text { Razoá- } \\
\text { vel }\end{array}$ & $\begin{array}{l}\text { Muito } \\
\text { Fraca }\end{array}$ & $\begin{array}{l}\text { Muito } \\
\text { Fraca }\end{array}$ & $\begin{array}{l}\text { Muito } \\
\text { Fraca }\end{array}$ & $\begin{array}{l}\text { Muito } \\
\text { Fraca }\end{array}$ & Fraca \\
\hline & Gestão do conhecimento do consumidor & $\begin{array}{l}\text { Muito } \\
\text { Forte }\end{array}$ & $\begin{array}{l}\text { Muito } \\
\text { Forte }\end{array}$ & Forte & $\begin{array}{c}\text { Razoá- } \\
\text { vel }\end{array}$ & $\begin{array}{c}\text { Razoá- } \\
\text { vel }\end{array}$ & Fraca & Fraca & $\begin{array}{l}\text { Razoá- } \\
\text { vel }\end{array}$ \\
\hline & Análise financeira & Forte & Forte & $\begin{array}{l}\text { Muito } \\
\text { Forte }\end{array}$ & Forte & $\begin{array}{l}\text { Razoá- } \\
\text { vel }\end{array}$ & $\begin{array}{l}\text { Muito } \\
\text { Fraca }\end{array}$ & Fraca & Forte \\
\hline & Mediana do constructo & $\begin{array}{l}\text { Muito } \\
\text { Forte }\end{array}$ & $\begin{array}{l}\text { Muito } \\
\text { Forte }\end{array}$ & Forte & Forte & $\begin{array}{c}\text { Razoá- } \\
\text { vel }\end{array}$ & Fraca & Fraca & Forte \\
\hline \multicolumn{2}{|r|}{ Mediana dos estudo de caso } & $\begin{array}{l}\text { Muito } \\
\text { Forte }\end{array}$ & $\begin{array}{l}\text { Muito } \\
\text { Forte }\end{array}$ & Forte & Forte & $\begin{array}{c}\text { Razoá- } \\
\text { vel }\end{array}$ & Fraca & Fraca & Forte \\
\hline
\end{tabular}

O constructo "Gestão de Negócios" teve aderência forte às práticas de DA, com destaque para o "Planejamento Estratégico" e a "Análise Financeira". A "Gestão do Conhecimento Gerada pelo Consumidor" foi verificada de forma razoável nas empresas. O "Controle da Qualidade" teve fraca aderência às práticas de DA das empresas, mostrando uma oportunidade a ser explorada, 
seja no aproveitamento das interações na Web como voz do consumidor ou na aplicação dos sistemas de qualidade para se analisar dados de DA.

\subsection{Alinhamento estratégico de DA e sua eficácia para os negócios}

A variável "Alinhamento entre estratégia e TI" teve alta influência nos resultados gerados com a aplicação de Digital Analytics. As quatro empresas que tiveram maior nota na aplicação de DA (segmentos de e-commerce, fonográfico, software e bebidas) foram justamente aquelas que tiveram maior nota na variável alinhamento entre estratégia e TI (Tabela 8.2). Isso significa que essas quatro empresas tinham indicadores de DA coerentes com o alinhamento entre a estratégia e a TI.

Três das empresas que tiveram melhor desempenho na aplicação de DA possuem um alinhamento entre estratégia e TI do tipo "Transformação Tecnológica" (HENDERSON \& VENKATRAMAN, 1993). Entende-se que para essas empresas os indicadores de DA são críticos para a eficácia organizacional (LAURINDO, 2008), pois elas ganharam competitividade ao explorar os espaços virtuais (ANGHERN, 1997) e superar seus competidores no marketspace (RAYPORT \& SVIOKLA, 1995).

Porém esse não é único caminho para se tornar competitivo com DA, umas das empresas que conseguiram tiram maior proveito com aplicações de DA foi a fabricante de bebidas, que possui um alinhamento entre estratégia e TI do tipo "Execução da Estratégia" (HENDERSON \& VENKATRAMAN, 1993). Apesar de boa parte da competitividade desse mercado prover de ativos físicos como a planta industrial e a distribuição dos produtos, marketplace, a empresa vislumbrou a possibilidade de obter vantagem competitiva no marketspace (RAYPORT \& SVIOKLA, 1995) utilizando para tanto os indicadores de WA.

O nível de maturidade do alinhamento de negócios e TI (LUFTMAN, 2003) também mostrou influência nos resultados das implantações de DA. As quatro empresas que tiveram melhor aderência, foram classificadas com nível de maturidade maior ou igual a 3 . As outras possuem nível 1 de maturidade. 
Portanto, parece mais importante para o resultado das implantações de DA que haja maturidade no nível de maturidade do alinhamento entre estratégia e TI do que no próprio tipo de alinhamento adotado.

A virtualidade impactou profundamente os três negócios com maior aderência às práticas de DA seja no nível organizacional (VENKATRAMAN \& HENDERSON, 1998) como no desenvolvimento de novos produtos (MATTOS \& LAURINDO, 2008). A empresa de e-commerce fechou suas lojas físicas e mantém atualmente apenas a operação na Internet; a empresa de software desenvolveu um produto do tipo software as a service (SAAS) minimizando a prestação de serviço in loco; e a Banda Mais Bonita da Cidade já nasceu virtual.

\subsection{Identificação dos elementos de sucesso na implantação de DA}

A identificação dos elementos de sucesso na implantação de DA passa pela discussão das proposições que foram verificadas nos estudos de caso conforme tabela 8.3.

Tabela 8.3: Confirmação das proposições

\begin{tabular}{|l|l|c|}
\hline \multicolumn{1}{|c|}{ Proposição } & Confirmação \\
\hline P1 & $\begin{array}{l}\text { Empresas que utilizam o potencial de DA: } \\
\text { - analisam dados qualitativos e quantitativos da experiência online de } \\
\text { seus clientes/consumidores; } \\
\text { - realizam benchmarks de seus concorrentes utilizando dados de } \\
\text { pesquisas de mercado, visita a sites e análise dos comentários de } \\
\text { clientes/consumidores nas redes sociais; } \\
\text { - melhoram continuamente sua presença online, assim como, seus } \\
\text { produtos e serviços, através das recomendações advindas de DA. }\end{array}$ & Total \\
\hline P2 & $\begin{array}{l}\text { DA pode gerar contribuições para a estratégia corporativa } \\
\text { P3 }\end{array}$ & $\begin{array}{l}\text { É possível melhorar o resultado das implantações de DA através de } \\
\text { um método que incorpore elementos da gestão de negócios }\end{array}$ \\
\hline
\end{tabular}

A P1 foi confirmada, pois se verificou que as empresas que utilizam melhor o potencial de DA, casos do segmento de e-commerce, fonográfico, software e bebidas, adotam as seguintes práticas (KAUSHIK, 2009):

- Analisam dados qualitativos e quantitativos da experiência online de seus clientes/consumidores. Isso pode ser observado, pois essas as 
empresas tiveram forte aderência no constructo Capacidade Analítica, usando fontes de dados quantitativas e qualitativas;

- Realizam benchmarks de seus concorrentes utilizando dados de pesquisas de mercado, visita a sites e análise dos comentários de clientes/consumidores nas redes sociais conforme forte aderência dessas empresas na variável Inteligência Competitiva;

- Melhoram continuamente sua presença online, como visto na aderência às variáveis usabilidade e otimização da presença ativa. Assim como, melhoram seus produtos e serviços, através das recomendações advindas de DA medida na variável co-criação de valor, embora se note que negócios com características mais virtuais, e-commerce e fonográfico, tem maior potencial para cocriação de valor que a fábrica de bebidas e que a empresa de software, que ainda depende muito da assistência técnica on the site.

A P2, que trata das contribuições de DA para a estratégia corporativa, foi confirmada. Pois as empresas que mais se destacaram (e-commerce, Banda, fabricante de bebidas e empresa de software) possuem forte alinhamento entre estratégia e TI e utilizam DA para criar valor através do e-business. Isso vale tanto paras as empresas com alinhamento estratégico de "Transformação Tecnológica" ou de "Alinhamento Estratégico" (HENDERSON \& VENKATRAMAN, 1993), o fator que se revelou mais importante para essa contribuição é o nível de maturidade do alinhamento (LUFTMAN, 2003).

A P3, que trata da incorporação de elementos de gestão do negócio à DA, foi confirmada parcialmente. Pois, mesmo entre as empresas que mais se destacaram, alguns elementos de gestão do negócio como o controle da qualidade (DAVIS et al.,2001) são pouco utilizados. A gestão do conhecimento do consumidor (GIBBERT et al., 2002; ZANINI \& MIGUELES, 2010; FOX, 2010) é usada de forma incipiente. Os elementos de gestão que foram considerados relevantes para prática de DA foram o planejamento estratégico (ROCKART, 1979; KAPLAN \& NORTON, 1997; YANAZE, 2011), pois os indicadores de DA podem ser utilizados na formulação e no refinamento das 
estratégias, e a análise financeira (YANAZE et al., 2010), que é vital para avaliar a viabilidade das ações online. 


\section{Considerações finais}

A pesquisa procurou elucidar as seguintes questões:

Q1. Como e porque as empresas aplicam os conceitos de DA em seus negócios?

Q2. Como é feito o alinhamento estratégico entre DA e os negócios?

Q3. De que forma DA pode aumentar a criação de valor estratégico?

Foi selecionado o método de estudos de casos (YIN, 2001), pois é o mais adequado para se esclarecer esse tipo de questões: o que e como.

O método do estudo de caso possui uma limitação inerente que é a dificuldade de generalização dos conhecimentos. Outras barreiras foram: a falta de tempo dos entrevistados e a concentração da investigação em unidades de negócios específicas, no caso do estudo de caso abordar empresas de grande porte.

Apesar das dificuldades, cumpriu-se o objetivo principal que era entender como as empresas utilizam o conceito de DA e determinar os fatores críticos para que elas possam obter proveito de uma implantação de DA.

Também houve êxito nos objetivos específicos.

- Foi elaborado um framework de WA (tabela 8.1) a partir de referências da literatura vinculadas às questões da pesquisa;

- Verificou-se empiricamente a aplicação desse framework através de sete estudos de caso (tabela 8.2);

- Entendeu-se que o alinhamento estratégico entre estratégia e TI e seu desdobramento através de indicadores de DA são relevantes para a eficácia nos negócios;

- Foram identificados os fatores críticos de sucesso ao se verificar as proposições (tabela 8.3).

As proposições tiveram confirmação parcial ou total. A P1 foi confirmada, indicando que empresas que se destacam no uso de DA, devem possuir capacidade analítica para analisar dados quantitativos e qualitativos, realizar benchmarks e melhorar continuamente a presença online (KAUSHIK, 2009).

A P2 também foi confirmada, demonstrando a importância de DA para a estratégia. Seja através de estratégias de transformação tecnológica ou através da execução de estratégias de negócio (HENDERSON \& VENKATRAMAN, 
1993). Foi verificado que o fator crítico de sucesso não é a forma da estratégia, mas o grau de maturidade do alinhamento (LUFTMAN, 2003).

A P3 foi confirmada parcialmente, pois se notou que o planejamento estratégico (ROCKART, 1979; KAPLAN \& NORTON, 1997; YANAZE, 2011) e a análise financeira (YANAZE et al., 2010) são elementos da gestão de negócios incorporados pelas empresas que melhor aplicam DA. O mesmo não se pode dizer de elementos como o controle da qualidade (DAVIS et al.,2001) e a gestão do conhecimento do consumidor (GIBBERT et al., 2002; ZANINI \& MIGUELES, 2010; FOX, 2010).

A identificação de fatores críticos de sucesso é relevante para empresas que desejem tirar proveito de DA. Os estudos de caso detalhados podem servir de referência para futuras pesquisas, que visem a elaboração de um modelo a partir das variáveis identificadas e a generalização dos conhecimentos obtidos nessa pesquisa. Para tanto, vislumbra-se a necessidade de estudos com abordagem quantitativa para verificar a validade do modelo proposto numa amostra representativa do universo de empresas brasileiras. 


\section{Referências bibliográficas}

ABIR - ASSOCIAÇÃO BRASILEIRA DAS REFRIGERANTES E BEBIDAS NÃO ALCOÓLICAS, Consumo de todas as bebidas comerciais, 2011. Disponível em http://abir.org.br/2011/10/24/dados-de-mercado-2011/. Acessado em 15 de Out. de 2012.

ABRELIVROS - ASSOCIAÇÃO BRASILEIRA DE EDITORES DE LIVROS ESCOLARES, Dados do mercado, 2012. Disponível em http://www.abrelivros.org.br/. Acessado em 15 de Out. de 2012.

ANGHERN, A. Design matures Internet business strategies: the ICDT model. European Management Journal, v.15, i.4, p.360-368, 1997.

AMIT, R.; ZOTT, C. Value Creation in E-Business. Strategic Management Journal, v.22, Jun/Jul, p.493-520, 2001.

ANALYTICS, A.; MENG. - Marketing Executives Networking Group. Marketing Trends Report 2010, Mar, 2010.2 Disponivel em http://www.andersonanalytics.com/index.php?mact=News,cntnt01, getfile,1\&cnt nt01 filename=AndersonAnalyticsMENG2010TrendReportFinal.pdf\&cntnt01 retur nid=46\&page=46, acessado em Out, 2012.

ANDERSON, C., A Cauda Longa: Do mercado de massa para o mercado de nicho, Ed. Elsevier, Rio de Janeiro, RJ, 2006.

ANDERSON, C., 2009. Netflix data shows shifting demand down the Long Tail. The Long Tail Chris Anderson's blog. Disponível em http://www.longtail.com/ aessado em Jan, 2011.

ARIELY, D., Being gamed: how online companies trick you into sharing more, joining more, and spending more. Wired, v. Jul, pp. 134-141, 2011.

ARUN, S., DACIN, P. A., PATTICHIS, C. Current Trends In Web Data Analysis, Communications of the ACM, November, Vol. 49, No. 11, pp. 85-91, 2006.

BERENDT, B.; HOTHO, A.; STUMME, S. Bridging the Gap-Data Mining and Social Network Analysis for Integrating Semantic Web and Web 2.0, Web Semantics: Science, Services and Agents on the World Wide Web, v. 8, pp. 9596, 2010.

BERKOWITZ, D. 100 Ways to Measure Social Media, 2012. Disponível em http://www.marketersstudio.com/2009/11/100-ways-to-measure-social-media.html\#axzz14fN05Fy9. Acessado em 17 de fevereiro de 2012. 
BOVET, D; MARTHA, J. Redes de Valor- Aumente os lucros pelo uso da Tecnologia da Informação na cadeia de valor, Negócio Editora Ltda, São Paulo, Brasil, 2001.

BRYNJOLFSSON, E.; HU, Y.; SMITH, M.D. Consumer surplus in the digital economy: Estimating the value of increased product variety at Online booksellers, Management Science, v.49, i.11, p. 1580-1596, 2003.

BUGHIN, J., SHENKAN, A., SINGER, M. How poor metrics undermine digital marketing, The McKinsey Quarterly, October 2008, pp.1-5, 2008.

BUCHANAN, J. R.; LINOWES, R. G. Understanding distributed data processing. Harvard Business Review, v. 58, n. 4, p. 143-153, 1980.

BUSINESSWEEK, The E-biz Surprise, BusinessWeek, Edição de 12 de Maio 2003, p.60-68, 2003.

CAPPS, R. The good enuf rvlutn: why lo-fi tech will rule the world, Wired, September 2009, p. 110-119, 2009.

CARVALHO, S.S. "O mercado de TI no Brasil: oportunidades e desafios", 2011. Disponível em http://www.digitaldoc.com.br/dwnl/idcmedianeira.pdf. Acessado em 01 de Dez. de 2011.

CASTELLS, M. A sociedade em rede. A era da informação: economia, sociedade e cultura. V 1. Ed. Paz e Terra, São Paulo, SP, 1999.

A galáxia da Internet. Reflexões sobre a Internet, os Negócios e a Sociedade. Ed. Jorge Zahar, Rio de Janeiro, RJ, 2003.

CAVALLINI, R.; REIS, T., 1aㅡ Pesquisa \#Mobilize Consumidor Móvel 2011, estudo realizado pela agência W/McCann e grupo Mobi com pesquisa realizada pelo instituto Ipsos Mediact. Disponível em http://www.proxxima.com.br/proxxima/indicadores/conectados/20110802-

Pesquisa-Mobilize-Consumidor-Movel-2011.html. Acessado em 23 de ago de 2011.

CHANDRASHEKAR, A.; SCHARY, P. B., Toward the Virtual Supply Chain: the convergence of IT and organization. International Journal of Logistics Management, v.10, n.2, p.27-39, 1999.

COMSCORE, website institucional, 2012. Disponível em http://www.comscore.com/por. Acessado em 09 de out. de 2012.

, The Brazilian Online Audience. Fevereiro de 2011. Disponível em http://www.comscore.com/por/Press_Events/Presentations_Whitepapers/2011/ State_of_the_Internet_in_Brazil. Acessado em 06 de set. de 2011. 
The comScore 2008 Digital Year in Review, 2009. Disponível em http://www.comscore.com/Press_Events/Presentations_Whitepapers/2009/200 8_Digital_Year_in_Review, 2009. Acesso em 01 de set. 09.

CUI, G.; GUO, X. The impact of online word-of-mouse: Sales of New Products at Amazon.Com. In Proceedings of ICE-B 2009 - International Conference on E-business, Milão, Itália, p.143-150, 2009.

CUTLER, M. and STERNE, J. E-Metrics: Business Metrics For The New Economy, NetGenesis, Chicago, IL, 2000.

CUTRONI, J. Google Analytics. Ed. O’Reilly Media, Sebastopol, CA, 2010.

CUTRONI, J. Radically Rethinking Web Analytics, 2012. Disponível em http://online-behavior.com/analytics/rethinking. Acessado em 12 de out. de 2012.

DAVIS, M. M.; AQUILANO, N. J.; CHASE, R. B. Fundamentos da administração da produção. Ed. Bookman. Porto Alegre, 2001.

DIGITAL ANALYTICS ASSOCIATION. Web Analytics Association Becomes Digital Analytics Association, 2012. Disponível em http://www.digitalanalyticsassociation.org/news/85508/Web-Analytics-

Association-Becomes-Digital-Analytics-Association.htm. Acessado em 12 de out. de 2012.

DIX, A.; LEPOURAS, G; KATIFORI, A.; VASSILAKIS, C.; CATARCI, T.; POGGI, A.P.; IOANNIDIS, Y., MORA, M., DARADIMOS. I; AKIM, N.M.; HUMAYOUN, S.S.; TERELLA, F. From the web of data to a world of action. Web Semantics: Science, Services and Agents on the World Wide Web, v.8, pp. 394-408, 2010.

E-CONSULTING, Varejo Online (VOL). Disponível em http://www.econsultingcorp.com.br/knowledge/indicadores-de-mercado/varejo-onlinevol/?searchterm=VOL. Acessado em 07 de set. de 2011.

, Varejo online. Disponível em http://vs34.pytown.com:8080/EConsulting/knowledge/indicadores-de-mercado/varejo-online-vol. Acesso em 01 de set. de 2009.

ENGE, E.; SPENCER, S.; FISHKIN, R.; STRICCHIOLA, J.C. The art of SEO, E. O'Reilly Media, Sebastopol, CA, 2009.

EIRINAKI, M.; VAZIRGIANNIS, M., Web Mining for Web Personalization, ACM Transactions on Internet Technology, v. 3, n. 1, pp. 1-27, 2003.

EVANS, P.B.; WURSTER, T.S., Getting real about virtual commerce. Harvard Business Review, v.77, n.6, pp.84-94, 1999. 
FACEBOOK. Estatísticas. Disponível em https://www.facebook.com/press/info.php?statistics. Acessado em 23 de ago. de 2011.

FARRIS, P.W; BENDLE, N.T.; PFEIFER, P.E.; REIBSTEIN, D.J.; Métricas de Marketing. Porto Alegre, Bookman, 2007.

FENABRAVE. Informativo Fenabrave - Emplacamentos, 2012a. Disponível em http://www.tela.com.br/dados_mercado/emplacamentos/index.asp?coditem=1. Acessado em 09 de out. de 2012.

FENABRAVE. Anuário 2011, 2012b. Disponível em http://www.fenabrave.org.br/principal/pub/lmage/20120425110423ANUARIO20 11.pdf. Acessado em 14 de out. de 2012.

FERRAZ, M. G., PRETO, M. Brasileiros usam financiamento dos fãs para produzir discos e shows, 2011. Disponível em http://www1 .folha.uol.com.br/ilustrada/970234-brasileiros-usam-financiamentodos-fas-para-produzir-discos-e-shows.shtml. Acessado em 01 de fevereiro de 2012.

FIAT, Site do modelo Fiat Mio, 2011. Disponível em http://www.fiatmio.cc. Acessado em 3 de fev. de 2011.

FOX, V. Marketing in the Age of Google: Your Online Strategy is Your Business Strategy. Ed. John Wiley \& Sons. New Jersey, 2010.

GARTNER. Magic Quadrant for Social CRM, 2012. Disponível em www.gartner.com/technology/reprints.do?id=1-1C71JU7\&ct=120927\&st=sb. Acessado em 8 de out. de 2012.

GOOGLE ADPLANNER. Quais websites atraem seu público-alvo? 2012. Disponível em https://www.google.com/adplanner. Acessado em 18 de ago. de 2011.

GOOGLE TRENDS. Google Trends, 2012. Disponível em http://www.google.com/trends/. Acessado em 09 de out. de 2012.

GIBBERT, M., LEIBOLD, M., PROBST, G. Five Styles of Customer Knowledge Management, and How Smart Companies Use Them To Create Value. European Management Journal, v. 20, n. 5, pp. 459-469, 2002.

HAO, T. China's e-commerce saw 20-percent jump in, 2008. Disponível em http://www.chinadaily.com.cn/bizchina/2009-01/05/content_7367065.htm, Acessado em 01 de set de 2009. 
HENDERSON, J.C. \& VENKATRAMAN, N., Strategic alignment: leveraging information technology for transforming organizations. IBM Systems Journal. V.32, n.1, p. 4-16, 1993.

IAB BRASIL- Internet Advertising Bureau Brasil, Indicadores de Mercado, 2011. Disponível em http://www.iabbrasil.org.br/arquivos/doc/indicadores/Indicadoresde-Mercado-IAB-Brasil.pdf. Acessado em 29 de jun. de 2011.

IBOPE - Painel de internautas brasileiros, 2012. Disponível em http://br.nielsennetpanel.com/pnl/br/home. Acessado em 09 de out. de 2012.

IDGNOW. Análise: Casas Bahia entra no e-commerce e desafia liderança da B2W, 2009. Disponível em http://idgnow.uol.com.br/internet/2009/02/02/analisecasas-bahia-entra-no-e-commerce-para-desafiar-dominacao-da-b2w. Acesso em 01 de set. de 2009.

INGRAM, M. What If Facebook Isn't So Special After All?, 2012. Disponível em http://www.businessweek.com/articles/2012-04-24/what-if-facebook-isn-t-sospecial-after-all. Acessado em 09 de out. de 2012.

INTERNET RETAILER, America's Top Ten Retail Businesses, disponível em http://www.internetretailer.com/top500/list.asp. Acesso em 01 de set. de 2009.

ISI WEB OF KNOWLEDGE, Web of Science, 2010. Disponível em http://apps.isiknowledge.com. Acessado em 23 de ago. de 2010.

KAPLAN, R. S. e NORTON, D. P. A estratégia em ação. Rio de janeiro, Campus, 1997.

KAUSHIK, A. Web Analytics: Uma hora por dia. Ed. Alta Books, Rio de Janeiro, 2009.

KAUSHIK, A. Excellent Analytics Tips \#20: Measuring Digital "Brand Strength", 2012. Disponível em http://www.kaushik.net/avinash/analytics-measuringdigital-brand-strength/. Acessado em 08 de out. de 2012.

KAUSHIK, A. Web Analytics 2.0. Indiana, Wiley Publishing, 2010.

KIM, W.A.; MAUBORGNE, R. A estratégia do oceano azul: como criar novos mercados e tornar a concorrência irrelevante. Rio de Janeiro, Ed. Elsevier, 2005.

KLOUT; Understanding Klout, disponível em http://klout.com/\#/understand. Acessado em 14 de fev. de 2012.

LAFUENTE, F. A era do raciocínio artificial. HSM Management, v.3, n.86, pp. 80-86, 2011. 
LARSEN, J., HANSEN, L. K., HAVE A.S., CHRISTIANSEN T., KOLENDA T., Webmining: learning from the world wide web. Computational Statistics \& Data Analysis, v. 38, pp. 517-532, 2002.

LAURINDO, F. J. B. Tecnologia da Informação: Planejamento e Gestão de Estratégias. São Paulo: Atlas, 2008.

LEMMENS, R.; ARJONA L. D.; AGRAVAL V. O caminho da e-performance. HSM Management, jul./ago. 2001. p. 74-80.

LENSKOLD, J. D. Marketing ROI. New York, McGraw-Hill, 2003.

LENSKOLD, J. D. Lead Generation Marketing Effectiveness Study, 2012. Disponível em http://www.lenskold.com/content/LeadGenROI_2012.html. Acesso em 08 de outubro de 2012.

LIMA, A.; VITORINO, J.; E REBÊLO, H. Buzzmonitor: A tool for measuring word of mouth level in online communities. In Proceedings of Internacional Conference on E-Commerce, IADIS'2005, Porto, Portugal, 2005.

LUFTMAN, J. N. Assessing strategic alignment maturity. In: LUFTMAN, J.N. (Ed.) Competing in the information age: align in the sand. New York: Oxford University Press, p. 15-48, 2003.

MATTOS, C.A.; LAURINDO, F. J. B. The role of the web in improving customer input to the service/product development process: Brazilian cases. Product: Management \& Development, v.6, n.1, p. 67-75, 2008.

MAYAR, V.; RAMSEY, G. Digital Impact. New Jersey, John Wiley \& Sons, Inc, 2011.

MCDERMOTT, J; CIPPOLONE, K.; WAA STANDARDS COMITTEE. Social Media Standards, 2010, p. 1-30. Disponível em http://c.ymcdn.com/sites/www.digitalanalyticsassociation.org/resource/resmgr/P DF_standards/WAAStandardsSocialMediaDefin.pdf. Acessado em 12 de out. de $\overline{2} 012$.

MDIC - MINISTÉRIO DO DESENVOLVIMENTO, INDÚSTRIA E COMÉRCIO EXTERIOR. Empresas brasileiras exportadoras e importadoras, 2008. Disponível em http://www.desenvolvimento.gov.br/sitio/interna/interna.php?area=5\&menu=603 . Acessado em 12 de Fev. de 2010.

MIGUEL, P. A. C. Estudo de caso na engenharia de produção: estruturação e recomendações para sua condução. Revista Produção, v.17, n.1, p. 216-229, Jan/Abr 2007.

MINTZBERG, H.; LAMPEL, J. Reflecting on the strategy process, Harvard Business Review, v. 40 (3), p. 21-30, 1999. 
MOL - MARKETING ONLINE, A ascensão do marketing online e a queda da mídia tradicional. Disponível em http://www.youtube.com/watch?v=67bkb0uqtaw\&feature=player_embedded\#!. Acessado em 24 de ago. de 2011.

MULLER, A. A revolução será tuitada, Amanhã, ano 24, n.274, PP. 8-12, 2011.

NASDAQ. Stock Reports. Disponível em http://www.nasdaq.com/quotes/. Acessado em 09 de out. de 2012.

NOTA FISCAL ELETRÔNICA, Conheça a NFe, 2012. Disponível em http://www.nfe.fazenda.gov.br/portal/principal.aspx. Acessado em 09 de out. de 2012.

PAVAN, M.; CARVALHO, P.L.B; BARRETO, R.S.; SILVA, T.S. Planejamento Estratégico de Marketing para a Sociedade Esportiva Palmeiras. Trabalho de Conclusão de Curso apresentado à Escola de Comunicações e Artes da Universidade de São Paulo como requisito parcial para obtenção do título de especialista em Gestão de Marketing e Comunicação, 2012. Disponível em http://pt.scribd.com/doc/109380350/Palmeiras-TCC-Final\#outer_page_125.

Acessado em 09 de out. de 2012.

PERES, M. Tendências de TI/Telecom, panorama mundial e dinâmica local, $2010 . \quad$ Disponível em http://www.softex.br/portal/softexweb/uploadDocuments/IDC\%20-

\%20Tend\%C3\%AAncias\%20de\%20T1\%20Softex\%20Fev\%2010\%20v1.pdf. Acessado em 01 de Dez. de 2011

PORTER, M.E, How Competitive forces shape strategy. Harvard Business Review, v.57, n.6, p.137-145, 1979.

, What is strategy? Harvard Business Review, v.74, n.6, p.61-78, 1996. p.63-78, 2001.

, Strategy and the Internet. Harvard Business Review, v.79, n.3,

PORTER, M.E; MILLAR, V.E., How information gives you competitive advantage. Harvard Business Review, v.63, n.4, p.149-160, 1985.

POWELL, G.R., Return on Marketing Investment. Atlanta: RPI Press, 2002.

PRAHALAD, C. K.; KRISHNAN, M.S.; The New Age of Innovation: Driving Cocreated Value Through Global Networks. New York, McGraw-Hill, 2008.

PRAHALAD, C. K.; RAMASWAMY, V. Co-opting Customer Competence. Harvard Business Review, v. 78, n. 1, pp. 79-87, 2000. 
PRAHALAD, C. K.; RAMASWAMY, V. Co-creation experiences: the next practice in value creation. Journal of Interactive Marketing, v.18, i.3, pp. 5-14, 2004.

RESEARCH AND MAKETS, UK B2C E-Commerce: Continued Growth in Tricky Times. Disponível em http://www.researchandmarkets.com/reports/651872/uk_b2c_e_commerce_con tinued_growth_in_tricky_times. Acesso em 01 de set. de 2009.

ROCHA, R. A.; BORTOLUZZI, A. C.; ZANINI, M. R. K; ZANINI JÚNIO, N. J. a internet e a reinvenção do mundo dos negócios. XXII Encontro Nacional de Engenharia de Produção, Curitiba - PR, 23 a 25 de outubro de 2002. Disponível

em http://www.abepro.org.br/biblioteca/ENEGEP2002_TR80_0515.pdf. Acessado em 06 de set. de 2011.

ROCKART, J.F., Chief executives define their own data needs. Harvard Business Review, v.57, n.2, p.81-92, 1979.

ROWE, M.; CIRAVEGNA, F. Disambiguating identity web references using Web 2.0 data and semantics. Web Semantics: Science, Services and Agents on the World Wide Web, v.8, pp. 125-142, 2010.

SAMPAIO, L. Procon suspende por 72 horas vendas dos sites Submarino, Americanas e Shoptime, 2012. Disponível em http://veja.abril.com.br/noticia/economia/procon-suspende-por-72-horasvendas-dos-sites-americanas-com-submarino-e-shoptime. Acessado em 9 de out. de 2012.

SCOTT, D. M. The new rules of marketing and PR, Ed John Wiley \& Sons, Hoboken, New Jersey, 2011.

SEGALL, R.; ZHANG, Q. Web mining technologies for customer and marketing surveys, Kybernetes, v. 38 No. 6, pp. 925-949, 2009

SELNER, C. Análise de requisitos para sistemas de informações, utilizando as ferramentas da qualidade e processos de software. Dissertação submetida à Universidade Federal de Santa Catarina, 1999. Disponível em http://www.eps.ufsc.br/disserta99/selner/. Acessado em 13 de nov. 2012.

SEN, A.; DACIN P.A.; PATTICHIS, C. Current trends in web data analysis. Communications of the ACM, v. 49, No. 11, pp. 85-91, 2006.

SHAMMA, D. A.; SHAW, R.;SHAFTON, P. L.; LIU, Y. Watch what I watch, using community activity to understand content. In proceedings of MIR-2007 the international workshop on Workshop on multimedia information retrieval, Ausburg, Alemanha, pp. 275-283, 2007. 
SHANKAR S.; YADAV M. S. Emerging Perspectives on Marketing in a Multichannel and Multimedia Retailing Environment. Journal of Interactive Marketing, v. 24, pp. 55-57, 2010.

SPONDER, M. Social Media Analytics: effective tools for building, interpreting, and using metrics. New York, McGraw-Hill Professional, 2012.

STERNE, J. Social Media Metrics: how to measure and optimize your marketing investment. New Jersey, John Wiley \& Sons, 2010.

TAGIALORI, G. Quase todo usuário da web no Brasil também entra em redes sociais, diz estudo, 2011. Disponível em http://tecnologia.uol.com.br/ultimasnoticias/redacao/2011/04/28/quase-todo-internauta-brasileiro-tambem-acessaredes-sociais-diz-estudo.jhtm. Acessado em 30 de jun. 2011.

TAPSCOTT, D. Rethinking Strategy in a Networked World (or how Michael Porter is wrong about the Internet), Strategy + Business, issue 24, 8p, 2001.

TAPSCOTT, D.; WILLIAMS, A.D. Wikinomics: como a colaboração em massa pode mudar o seu negócio, Ed. Nova Fronteira, Rio de Janeiro, 2007.

TARAPANOFF, K. Inteligência social e inteligência competitiva. Revista Eletrônica de Biblioteconomia e Ciência da Informação, n. esp, pp.11-26, 2004.

TEIXEIRA, J. Nasce um gigante, 2008. Disponível em http://veja.abril.com.br/120308/p_091.shtml. Acessado em 9 de out. de 2012.

TERRA, J.C.; ALMEIDA, C.; ALMEIDA, D.A.; SIANO, A.I.; Varejo 2.0. Harvard Business Review, edição especial Marketing \& Vendas. V. 89, n.8, pp. 66-72, 2011.

VENKATRAMAN, N.; HENDERSON, J.C. Real Strategies for Virtual Organizing. Sloan Management Review, Boston, v. 40, n. 1, p. 33-48, 1998.

WA CONSULTING. Estudo de Mercado de Web Analytics do Brasil, p. 1-12. 2009. Disponivel em http://www.waconsulting.com.br/download.php?area=pesquisas\&key=3bf2de6a c767493603106d5dc3ce845a. Acessado em 14 de fev. de 2011.

WA CONSULTING. II Estudo de Mercado de Web Analytics do Brasil, p. 1-15. 2010. Disponivel em http://www.waconsulting.com.br/downloads.php?tipo=2. Acessado em 29 de jun. de 2011.

WAA - WEB ANALYTICS ASSOCIATION. Web Analytics Definitions, p. 1-32, $2008 . \quad$ Disponível em http://c.ymcdn.com/sites/www.webanalyticsassociation.org/resource/resmgr/PD F_standards/WebAnalyticsDefinitions.pdf. Acessado em 12 de out. de 2012. 
WEBSHOPPERS. WebShoppers, 26 $6^{\underline{a}}$ edição, 2012. Disponível em http://www.webshoppers.com.br/. Acessado em 09 de out. de 2012.

WIKIPEDIA. Home. Disponível em http://www.wikipedia.org/. Acessado em 24 de ago. de 2011.

ZANINI, M.T.; MIGUELES, C. Gestão Integrada de Ativos Intangíveis, 2010. Disponìvel http://www.symballein.com.br/images/stories/pdfs/Gestao_Integ_Ativos_Intangi veis.pdf. Acessado em 8 de out. de 2012.

ZHANG, Q.; SEGALL, R. Review of data, text and web mining software, Kybernetes, Vol. 39 No. 4, pp. 625-655, 2010.

YANAZE, M. H. Gestão de Marketing e Comunicação: avanços e aplicações. São Paulo, Saraiva, 2011.

YANAZE, M. H., FREIRE, O., SENISE, D. Retorno de investimentos em comunicação: avaliação e mensuração, Ed. Difusão, São Caetano do Sul, SP, 2010.

YIN, R. K., Estudo de caso - Planejamento e método. 2ª Edição, Ed. Bookman, São Paulo, SP, 2001.

YOUTUBE, Fiat Mio - Salão Brasil 2010. Disponível em http://www.youtube.com/watch?v=JoWbUR4b9io. Acessado em 3 de fevereiro de 2011. 